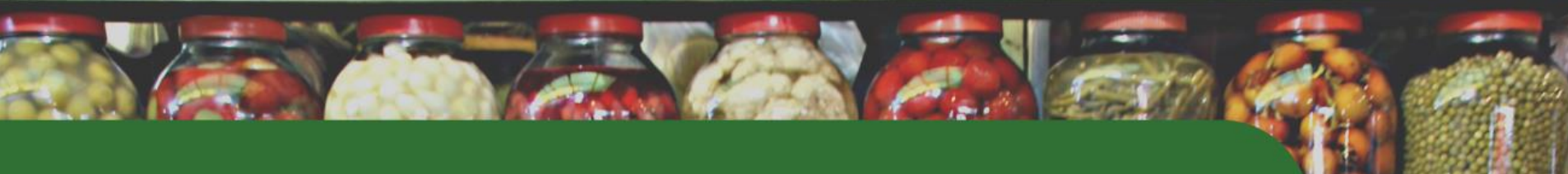

Ciência e Tecnologia

dos Alimentos

arention

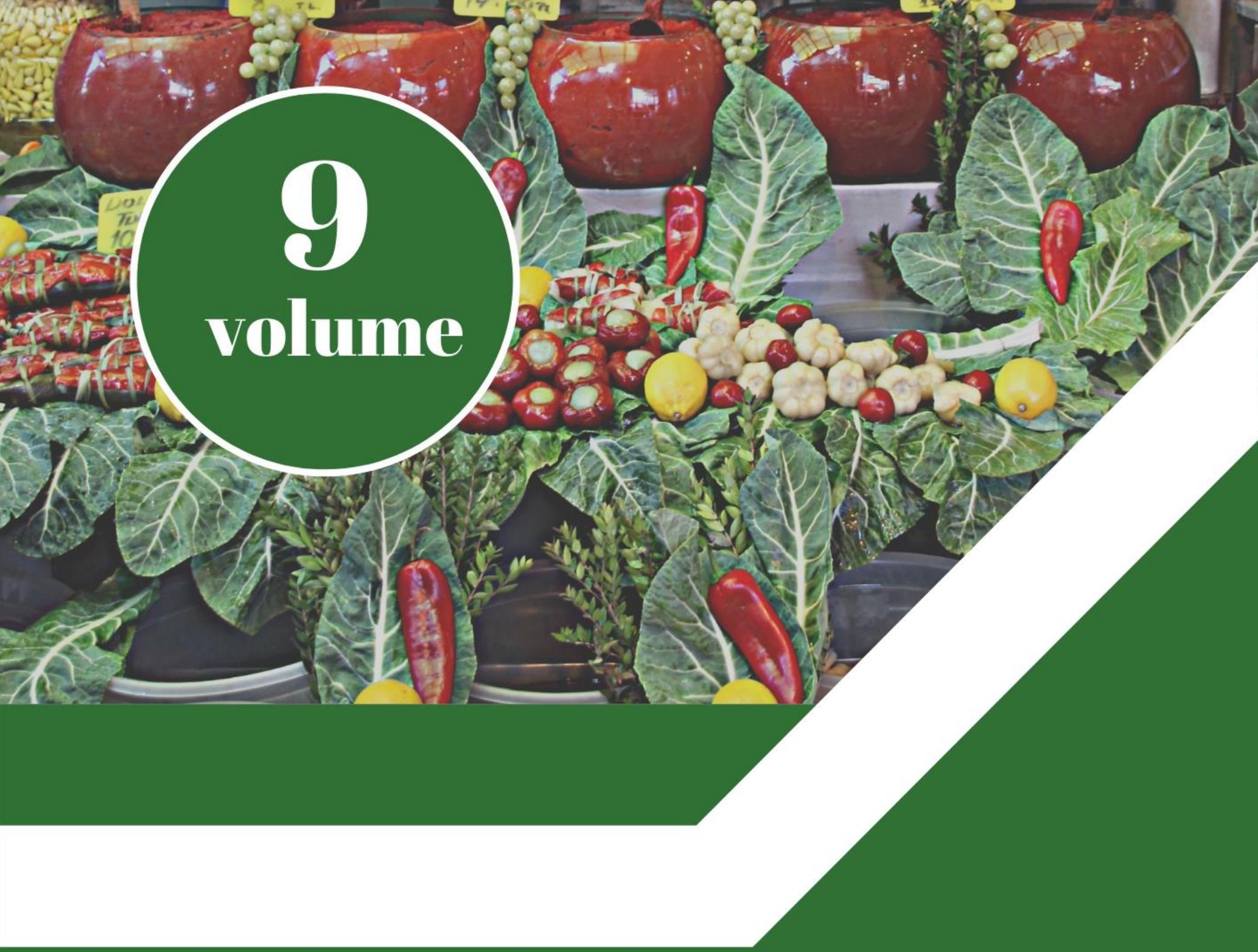

ate

\title{
volume
}


Editora Poisson

\section{Ciência e Tecnologia dos Alimentos Volume 9}

1a Edição

Belo Horizonte

Poisson

2020 
Editor Chefe: Dr. Darly Fernando Andrade

\section{Conselho Editorial}

Dr. Antônio Artur de Souza - Universidade Federal de Minas Gerais Msc. Davilson Eduardo Andrade

Dra. Elizângela de Jesus Oliveira - Universidade Federal do Amazonas

Msc. Fabiane dos Santos

Dr. José Eduardo Ferreira Lopes - Universidade Federal de Uberlândia

Dr. Otaviano Francisco Neves - Pontifícia Universidade Católica de Minas Gerais

Dr. Luiz Cláudio de Lima - Universidade FUMEC

Dr. Nelson Ferreira Filho - Faculdades Kennedy

Msc. Valdiney Alves de Oliveira - Universidade Federal de Uberlândia

\begin{tabular}{|l} 
Dados Internacionais de Catalogação na Publicação (CIP) \\
C569 \\
Ciência e Tecnologia dos Alimentos-Volume 9/ Organização Editora \\
Poisson - Belo Horizonte - MG: Poisson - 2020 \\
Formato: PDF \\
ISBN: 978-65-5866-031-6 \\
DOI: 10.36229/978-65-5866-031-6 \\
Modo de acesso: World Wide Web \\
Inclui bibliografia \\
1. Tecnologia de Alimentos 2. Alimentos 3. Nutrição I. Título \\
CDD-664.005
\end{tabular}

O conteúdo dos artigos e seus dados em sua forma correção e confiabilidade são de responsabilidade exclusiva dos seus respectivos autores.

www.poisson.com.br

contato@poisson.com.br 


\section{SUMÁRIO}

Capítulo 1: Caracterização de minerais em méis de abelhas Apis mellifera L. e Melipona subnitida D. em diferentes regiões do Ceará. 06

Kananda Lara Santos Sales, Kamila de Lima Barbosa, Amanda Batista Nascimento, Geovana Costa Aguiar, Álvaro Ventorini Vasconcelos, Maria da Conceição Tavares Cavalcanti Liberato

DOI: 10.36229/978-65-5866-031-6.CAP.01

Capítulo 2: Análises físico-químicas de méis das floras angico e silvestre dos estados de Minas Gerais e Rio Grande do Sul. 24

Amanda Batista Nascimento, Maria da Conceição Tavares Cavalcanti Liberato, Kamila de Lima Barbosa, Kananda Lara Santos Sales, Renata Almeida Farias, Kessia Oliveira Targino, Erica Carneiro de Sousa

DOI: $10.36229 / 978-65-5866-031-6 . C A P .02$

Capítulo 3: Parâmetros físicos e químicos na caracterização de pães elaborados com casca de pitaya como substituto parcial de farinha integral. 28

Nathália Maioli Crema, Gabrielly Ribeiro Carneiro, Leomara Floriano Ribeiro

DOI: 10.36229/978-65-5866-031-6.CAP.03

Capítulo 4: Influência do tempo de cocção nos teores de carotenóides totais de cinco variedades de pupunhas (Bactris gasipaes kunth).

Danyelly Silva Amorim, Isabelly Silva Amorim, Jamille de Sousa Monteiro, Ingryd Rodrigues Martins, Kássia Rodrigues da Costa Sena, Marcos Daniel das Neves Sousa, Maria Renara Alves Rodrigues, Francisca Mariane Martins Araújo, Ana Carla Alves Pelais

DOI: $10.36229 / 978-65-5866-031-6 . C A P .04$

Capítulo 5: Influência do pH e da adição de carboximetilcelulose sobre a fabricação e propriedades de filmes a base de proteina de soja 36

Jaqueline dos Santos de Oliveira, Angela Maria Picolloto, Laís Ravazzi Amado, Keila de Souza Silva

DOI: 10.36229/978-65-5866-031-6.CAP.05

Capítulo 6: Eficiência da xantana pruni na produção de bolos sem glúten ... 45

Leidi Daiana Preichardt, Claire Tondo Vendruscolo, Angelita da Silveira Moreira, Márcia Arocha Gularte D0I: 10.36229/978-65-5866-031-6.CAP.06

Capítulo 7: Massa de pizza low carb a base de couve-flor 49

Andressa Rafaella da Silva Bruni, Valéria Oliari Moreto, Aline Chiczta, Felipe Balicki Corrêa, Bruno Podolak, Katielle Rosalva Voncik Córdova, Herta Stutz

DOI: 10.36229/978-65-5866-031-6.CAP.07 


\section{SUMÁRIO}

Capítulo 8: Produção de exopolissacarídeos por Lentinula edodes e Ganoderma lucidium em diferentes néctares de frutas. 56

Kennidy de Bortoli, Daiane Cristina Lenhard

DOI: $10.36229 / 978-65-5866-031-6 . C A P .08$

Capítulo 9: Salmonella sp p. e coliformes em orégano e alho poró comercializados em feiras livres no município de Pelotas - RS 61

Tatiane Kuka Valente Gandra, Caroline Pereira das Neves, Eduarda Caetano Peixoto, João Paulo de Paiva Lemos, Vanessa Garcia Monteiro, Eliezer Avila Gandra

DOI: $10.36229 / 978-65-5866-031-6 . C A P .09$

Capítulo 10: Avaliação da toxicidade do óleo essencial de tomilho (Thymus vulgaris L.) 68

Adriana Biasi Vanin, Gláucia Freiberger, Bruna Albiero, José Carlos Azzolini

DOI: $10.36229 / 978-65-5866-031-6 . C A P .10$

Capítulo 11: Avaliação do consumo e qualidade de produtos lácteos da alimentação escolar de Jupiá - SC.

Daniela Paula Scanagatta, Karine Gabriel, Fabiane Picinin de Castro Cislaghi, Andréa Cátia Leal Badaró DOI: $10.36229 / 978-65-5866-031-6 . C A P .11$

Capítulo 12: Avaliação da eficiência da implantação de Procedimento Operacional Padronizado (POP) em uma Unidade de Alimentação e Nutrição Institucional. 79

Elaine Alves dos Santos, Deborah Santesso Bonnas

DOI: $10.36229 / 978-65-5866-031-6 C A P .12$

Capítulo 13: Cinética de secagem da curcuma (Curcuma longa L.). 83

Ana Teresa Rodrigues França, Barbara Daniele Almeida Porciuncula

DOI: 10.36229/978-65-5866-031-6.CAP.13

Capítulo 14: Moagem seca e condicionada do malte pilsen em moinho industrial de dois rolos em uma Instituição Privada do Centro-Oeste do Paraná. 90

Brayane Buhali, Karina Czaikoski, Franciely Ignachewski

DOI: 10.36229/978-65-5866-031-6.CAP.14

Autores: 


\section{Capítulo 1}

Caracterização de minerais em méis de abelhas Apis mellifera L. e Melipona subnitida D. em diferentes regiões do Ceará

Kananda Lara Santos Sales

Kamila de Lima Barbosa

Amanda Batista Nascimento

Geovana Costa Aguiar

Álvaro Ventorini Vasconcelos

Maria da Conceição Tavares Cavalcanti Liberato

Resumo: Devido ao papel de polinização realizado pela abelha no meio ambiente e produção de mel, cera, pólen e geléia real, ela é considerada de grande importância para o planeta. Este trabalho visou quantificar compostos inorgânicos ( $\mathrm{Ca}, \mathrm{Cu}, \mathrm{Fe}, \mathrm{Mg}, \mathrm{Zn}$ e $\mathrm{Mn}$ ) contidos em amostras de mel oriundos do estado do Ceará procedentes das espécies de abelhas Apis mellifera L. e Melipona subnitida D. Foram realizadas análises para determinação do teor de cinzas e para quantificação dos minerais através de Espectrometria de Absorção Atômica (EAA). A quantificação de cinzas atingiu uma variação de $0,01 \%$ a $0,28 \%$. O limite permitido pela legislação brasileira é de 0,6\%, estando, portanto, todas as amostras dentro do valor permitido. Foram quantificados nas amostras de méis analisados os minerais $\mathrm{Ca}, \mathrm{Cu}, \mathrm{Fe}, \mathrm{Mg}$, $\mathrm{Zn}$ e $\mathrm{Mn}$. Nas amostras os elementos apresentaram concentrações adequadas à Legislação, com algumas concentrações maiores de Ca e Mg. Cálcio e Magnésio são macronutrientes extremamente importantes para seres humanos e plantas sendo predominantes nas amostras. Os valores médios obtidos para $\mathrm{Ca}, \mathrm{Cu}, \mathrm{Fe}, \mathrm{Mg}$, $\mathrm{Zn}$ e $\mathrm{Mn}$ em $\mathrm{mg} / 100 \mathrm{~g}$ foram: 47,90-210,88 para Ca; 0,0-0,42 para Ferro; 0,55-1,50 para Magnésio; 0,02-0,249 para Zinco e 0,0-0,112 para Mn. Não foi detectado valores para o Cobre nas amostras. A concentração dos minerais no mel depende de diversos fatores ambientais podendo ser considerados contaminantes do meio ambiente, afetando a qualidade do mel.

Palavras-chave: Apis mellifera L., Melipona subnitida D., mel e minerais. 


\section{INTRODUÇÃO}

Segundo a Legislação Brasileira, o mel é produzido pelas abelhas, a partir do néctar das flores, das secreções procedentes de partes vivas de plantas ou de excreções de insetos sugadores que ficam sobre parte vivas de plantas, que as abelhas recolhem, transformam, combinam com substâncias específicas próprias, armazenam e deixam madurar nos favos da colméia (BRASIL, 2000). O mel é um produto de alto valor nutritivo, com inúmeras propriedades, excelente aceitabilidade pelo consumidor, com qualidade e composição físico-química variando conforme a condição climática da região, origem botânica visitada pelas abelhas, estágio de maturação e condições de manuseio do apicultor (RACOWSKI et al., 2007). A procura por alimentos naturais tem gerado uma solicitação crescente por produtos apícolas, proporcionando maior participação do mel na alimentação humana. Além de possuir propriedades terapêuticas, o mel destaca-se como suplemento alimentar. Isso se justifica através da análise do mel que demonstra ser um alimento rico em micronutrientes como vitaminas e minerais (AZEREDO, L. C.; AZEREDO, M. A. A.; DUTRA, 2003). A concentração de substâncias minerais possui uma larga faixa de variação. A coloração dos méis brasileiros possui grande variação, influenciando muitas vezes na preferência do consumidor, que escolhe o produto pela aparência. A cor do mel está relacionada com sua origem floral, o processamento e armazenamento, fatores climáticos durante o fluxo de néctar, a temperatura na qual o mel amadurece na colméia e o conteúdo de minerais presentes. Méis mais escuros tendem a conter mais minerais que méis mais claros (MARCHINI et al., 2005). As abelhas realizam a tarefa de polinização das colheitas, sendo importantes para a produção comercial do mel. Cotidianamente, cerca de 10.000 a 25.000 abelhas operárias fazem em média 10 viagens para explorar aproximadamente $7 \mathrm{~km}^{2}$ nas áreas que cercam seu habitat, recolhendo o néctar, a água e o pólen das flores. Durante este processo, diversos microrganismos, produtos químicos e partículas suspensas no ar são interceptados por elas e ficam retidos nos pelos superficiais de seu corpo ou são inalados e unidos em seu aparelho respiratório (WINSTON, 1987). Os testes realizados nesse trabalho permitiram quantificar alguns minerais presentes nas amostras de mel, observando se suas concentrações estão em consonância com a Legislação Brasileira vigente.

\section{OBJETIVOS}

Geral: Detectar elementos minerais em méis produzidos pelas abelhas Apis mellifera L. e Melipona subnitida D. no Ceará.

Específicos: 1) Determinar e quantificar o teor de cinzas nas amostras de méis, de forma a averiguar a presença de minerais; 2) Quantificar elementos minerais contidos nas amostras de méis analisados através de Espectrometria de Absorção Atômica por Chama (EAA); 3) Comparar as concentrações obtidas nos testes das amostras de méis analisados no laboratório com os níveis permitidos pela legislação.

As abelhas são insetos sociais pertencendo ao Reino Animal, a Classe dos Insetos e a Ordem Himenóptera. Essa ordem inclui 100.000 espécies de vespas, formigas e abelhas. Devido à sua perfeita organização e grande utilidade para o homem, a abelha é que tem maior importância entre essas espécies. As abelhas surgiram na face da Terra há mais de 50 milhões de anos (DUARTE, 2006). Vivem em grandes sociedades, onde a ordem é sempre a sobrevivência da própria espécie (PINHO FILHO, 2007). Em todo o mundo existem cerca de vinte mil espécies de abelhas que polinizam plantas floríferas, estimadas em mais de 225 mil espécies. Elas estão entre os mais importantes organismos vivos que são afetados pelas condições ambientais possuindo grande habilidade em sentir mudanças nos ambientes (ALMEIDA-ANACLETO, 2007). As abelhas são morfologicamente adaptadas para: coletar, manipular, carregar e estocar pólen e outros produtos das plantas, tendo sua origem no início do período meio-Cretáceo, em sincronia com as angiospermas (DANFORTH et al., 2006). As abelhas são insetos extremamente importantes tanto ecológica quanto economicamente. Ecologicamente, por sua atuação como organismos polinizadores, importantes no processo de reprodução de diversos vegetais. Economicamente, por seus inúmeros produtos apícolas, como mel, cera, geléia real e própolis, que são utilizados para promoção de emprego e renda (SOUSA et al., 2013).

\section{Abelha Apis mellifera}

O gênero Apis pertence a uma linhagem antiga de abelhas que alcançou a Europa no final do Pleistoceno, 10.000 anos atrás. No gênero Apis encontram-se várias espécies, porém a mais usada na produção de mel em todo o mundo é a Apis mellifera L. Só as abelhas sociais são domesticáveis e destas a Apis mellifera L. é a espécie mais usada na produção comercial de mel (RAMOS et al., 2007). 
A diversidade de clima e vegetação acarretou diversas subespécies dessa abelha, que são adaptadas às inúmeras condições do ambiente, permitindo um habitat bem amplo, abrangendo savanas, florestas tropicais, desertos, regiões litorâneas e montanhosas (PEREIRA et al., 2003). É um inseto extremamente organizado e disciplinado convivendo em um sistema de bastante organização. Em cada colméia existem cerca de 60 mil abelhas e cada colônia é constituída por uma única rainha, dezenas de zangões e milhares de operárias (CICCO, 2007). Sendo um inseto social, cada abelha melífera não sobrevive sozinha, dependendo da divisão dos trabalhos. A colônia possui três castas distintas, onde se identificam dois tipos de fêmeas (a rainha e as operárias) pelas características específicas, e um tipo de macho (os zangões) (WOLFF, 2008).

A abelha rainha tem uma importância crucial, pois é a única fêmea cuja reprodução é constantemente ativa, sendo também responsável pela manutenção de harmonia dos trabalhos da colônia, os quais são definidos pela liberação de feromônios (BIENEFELD \& PIRCHNER, 1990; SLESSOR et al., 2005). No início da vida reprodutiva da abelha rainha, cerca de cinco a seis dias após emergir, para ser fecundada se realiza o vôo nupcial, se as condições climáticas permitirem (CRAMP, 2008; SENAR, 2010). Os zangões são machos, possuem características específicas, como a ausência do ferrão, não coletam pólen ou néctar, não produzem cera e não possuem glândulas odoríferas (FREITAS, 1999).

As abelhas operárias são abelhas fêmeas não fecundadas, possuindo menor porte entre as demais, constituindo o maior número da população, entre 50 a 80 mil por enxame (FREITAS, 1999). As atividades obedecem a uma escala de trabalho geralmente associada com a idade do indivíduo e o desenvolvimento de suas glândulas (SENAR, 2010). 0 corpo da Apis mellifera L. é dividido em três partes: cabeça, tórax e abdome. Na cabeça, estão os olhos, as antenas, o aparelho bucal e, internamente, as glândulas (PEREIRA et $a l$, 2003). No tórax estão os órgãos locomotores, pernas e asas e a presença de pelos responsáveis pela fixação dos grãos de pólen quando as abelhas entram em contato com as flores (NOGUEIRA COUTO \& COUTO, 2002). No abdome, estão órgãos do aparelho digestivo, circulatório, reprodutor, excretor, órgãos de defesa e glândulas produtoras de cera (PEREIRA et al, 2003).

\section{Abelha Melipona Subnitida D}

Melipona subnitida é uma espécie de abelha que não possui ferrão. São insetos sociais de grande diversidade, porém sua produção de mel é inferior à da Apis mellifera. 0 mel dessa espécie é um produto especial, orgânico e raro, possuindo aroma e sabor bem específicos (VENTURIERI, 2008). As abelhas sem ferrão convivem com o homem desde o período pré-colombiano no continente Americano. Na América Latina encontram-se aproximadamente 300 espécies, a maioria delas produtoras de méis de grande aceitação (CARVALHO et. al., 2005). A abelha Melipona subnitida, conhecida como Jandaíra, é uma abelha característica do Nordeste Brasileiro, região que em sua maior parte, pertence ao bioma Caatinga. Faz parte de um grupo que inclui cerca de 250 espécies no território brasileiro, chamado de abelhas sem ferrão ou meliponíneos (CAMARGO et al., 2007). No estado do Ceará, a Melipona subnitida ocorre, aparentemente, em toda a planície sertaneja, desde o litoral até o sul, próximo da Chapada do Araripe (BÔAS, 2012). As colônias são formadas principalmente por rainha, operárias e machos, variando a quantidade de indivíduos de acordo com a espécie, podendo encontrar-se colônias com poucas centenas até as colônias formadas por cerca de 180 mil indivíduos (ALMEIDA; LAROCA, 1998; BRUENING, 2006; SOUSA et al., 2009). Conforme a morfologia das abelhas sem ferrão, a cabeça é subdivida em olhos, ocelos, antenas e mandíbula. Na parte externa do tórax, observam-se encaixados, dois pares de asas e três pares de pernas (VENTURIERI, 2008).

\section{Mel}

É uma substância viscosa, com características específicas, possuindo sabor e aromas próprios, alto valor energético e rico em açúcares (AROUCHA, 2008). Um produto doce produzido por abelhas a partir do néctar das flores ou de secreções de diferentes plantas (CORTÉZ et al. 2011; PEREIRA e REIS, 2015). É classificado como um adoçante natural, sendo usado mundialmente, por possuir diversas propriedades terapêuticas. Seu consumo pela população brasileira está mais restrito às propriedades medicinais, sendo muito utilizado no tratamento de gripes e resfriados, ainda que seja um alimento energético de boa qualidade (CAMARGO et al, 2006). 0 mel pode ser especificado através de sua origem como mel floral ou mel de melato. 0 mel floral é obtido dos néctares das flores, classificando-se em monofloral (quando originário de flores da mesma família, gênero ou espécie e possua características próprias) ou multifloral (originado de diferentes origens florais). 0 mel de melato é originado de secreções de partes vivas das 
plantas ou de excreções de insetos sugadores de plantas que se encontram sobre elas (BRASIL, 2000). Composição do mel: A composição química do mel depende da fonte de néctar e da origem floral do néctar recolhido pelas abelhas (PONTES et al., 2007). Sazonalidade, fatores ambientais e processamento influenciam na composição (ALVAREZ-SUAREZ et al., 2010). O mel de abelhas é composto por aproximadamente 181 substâncias, sendo uma mistura de diferentes carboidratos como frutose, glucose, maltose e sacarose, proteínas, aminoácidos, vitaminas, enzimas, flavonóides, minerais dentre outros como indicados na Tabela 1 (CHOW, 2002).

Tabela 01 - Composição básica do mel

\begin{tabular}{|l|c|c|c|}
\multicolumn{1}{c}{ Componentes } & \multicolumn{1}{c|}{ Média } & Desvio padrão & Variação \\
\hline Água (\%) & 17,2 & 1,46 & $13,4-22,9$ \\
\hline Frutose (\%) & 38,19 & 2,07 & $27,25-44,26$ \\
\hline Glicose (\%) & 31,28 & 3,03 & $22,03-40,75$ \\
\hline Sacarose (\%) & 1,31 & 0,95 & $0,25-7,57$ \\
\hline Maltose (\%) & 7,31 & 2,09 & $2,74-15,98$ \\
\hline Açucares totais(\%) & 1,5 & 1,03 & $0,13-8,49$ \\
\hline Outros (\%) & 3,1 & 1,97 & $0,0-13,2$ \\
\hline pH & 3,91 & - & $3,42-6,10$ \\
\hline Acidez livre(meq/kg) & 22,03 & 8,22 & $6,75-47,19$ \\
\hline Lactose (meq/kg) & 7,11 & 3,52 & $0,00-18,76$ \\
\hline Acidez total (meq/kg) & 29,12 & 10,33 & $8,68-59,49$ \\
\hline Lactose/Acidez livre & 0,335 & 0,135 & $0,00-0,950$ \\
\hline Cinzas (\%) & 0,169 & 0,15 & $0,020-1,028$ \\
\hline Nitrogênio (\%) & 0,041 & 0,026 & $0,00-0,133$ \\
\hline Diastase & 20,8 & 9,76 & $2,1-61,2$ \\
\hline
\end{tabular}

Fonte: PEREIRA et al.,2003.

O mel mesmo sendo basicamente uma solução saturada de água e açúcares, possui outros componentes, que se associam a florada (PEREIRA et al., 2003). Sua caracterização é um fator importante no controle de qualidade e na padronização de produtos apícolas, principalmente nas indústrias alimentícias, farmacêuticas e no meio ambiente (LINS et al., 2005; NEVES; ALENCAR; CARPES, 2009). Cinzas e Minerais: Os minerais presentes no mel são expressos através do teor de cinzas, muito utilizado na verificação da qualidade do produto. Esses minerais podem ser alterados por fatores relativos às abelhas, ao apicultor ou meliponicultor, clima, solo e origem botânica (CARVALHO et al., 2000).

Ocorre uma variação mineral no mel de 0,1 a 0,2\% (HERNÁNDEZ et al., 2005), onde o solo é a principal fonte, no qual os elementos são absorvidos pelas plantas por meio do sistema radicular (STANKOVSKA et al., 2008). Diversos elementos químicos foram identificados no mel, como $\mathrm{Ba}, \mathrm{Be}, \mathrm{Bi}, \mathrm{Ca}, \mathrm{Pb}, \mathrm{Co}, \mathrm{Cu}, \mathrm{Sn}, \mathrm{Sr}$, Fe, Ga, Ge, Li, Mg, Mn, Mo, Ni, Os, Au, K, Ag, Na, Ti, V e Zn (MBIRI et al., 2011; VANHANEN et al., 2011). Pode ainda apresentar alguns metais tóxicos, derivados da poluição ambiental ou da contaminação durante a produção e manejo (MCINNES, 2006). A coloração do mel é influenciada diretamente pelos minerais, apresentando-se em maiores concentrações em méis mais escuros em relação a méis mais claros (SANTOS et al., 2009). A qualidade e quantidade de elementos minerais no mel dependem da composição elementar das flores usadas pelas abelhas na coleta do néctar que varia de acordo com a fonte da vegetação e a distribuição espacial (PISANI et al., 2008). Fontes geográficas e botânicas são fatores que influenciam na presença de minerais no mel, porém fatores antropogênicos também atuam nas concentrações desses elementos, uma vez que nas áreas forrageadas pelas abelhas, sempre ocorre o contato com o ar, plantas, água e solo da região ao procurarem néctar, pólen e exsudatos vegetais (BOGDANOV, 2006).

Havendo contaminação ambiental no local de forrageamento, as abelhas se contaminam e transportam poluentes do ambiente para a colméia, modificando a composição e qualidade dos produtos apícolas (IOANNIDOU et al. 2005; BOGDANOV, 2006; TUZEN et al., 2007). Dentre esses minerais são considerados contaminantes o Zinco e o Cobre, conhecidos como potenciais contaminantes do ar ou solo de origem antropogênica, mas são também encontrados como ingredientes naturais dos minerais do solo assim como Ferro e Manganês. A variação no conteúdo de elementos traços em diferentes tipos de méis é primariamente devido à origem botânica de preferência à origem geográfica e à exposição ambiental de fontes de néctar (BOGDANOV et al., 2007). No Brasil, o início da criação de abelhas Apis mellifera começou a partir da introdução dessa espécie pelos europeus no século XVII (WOLFF, 2008). Atualmente a apicultura está sendo executada em ambientes extremamente urbanizados, possibilitando a exposição das abelhas a contaminantes. As mesmas acabam, indiretamente, contaminando seus produtos, pois visitam 
diversos setores do ambiente, devido à grande atividade de forrageamento em busca de alimento contaminando-se diretamente em possíveis fontes poluidoras (WOLF; REIS; SANTOS, 2008).

O Nordeste é uma região que apresenta destaque em criação de abelhas sem ferrão, de forma rústica, utilizando troncos como ninhos, possuindo instalações modestas (CARVALHO et al., 2014). No estado do Ceará já foram realizados diversos levantamentos para coletar plantas, abelhas sem ferrão e sua diversidade (FELIX, 2015). 0 estudo e conhecimento das plantas que fornecem recursos tróficos para as abelhas são importantes para a preservação, manejo e produção agrícola (VIDAL; SANTANA; VIDAL, 2008). As floradas dos méis analisados da abelha Apis mellifera, foram: Silvestre, Vassourinha-de-Botão e as floradas dos méis da Melipona subnitida, foram: Marmeleiro, Silvestre e Mofumbo.

O Nordeste Brasileiro é uma região com condições favoráveis para a produção de mel, possuindo uma imensa diversidade de florada (característica que fornece ao mel propriedades variadas como cor e aroma), condições climáticas favoráveis e mão de obra no meio rural (PIRES, 2011). Os produtos apícolas do Estado do Ceará possuem características peculiares devido a existência de vegetação mista com encraves de cerrado e Mata Atlântica na Caatinga, presença de mangues, possuindo climas com certas variações (LIBERATO et al., 2016). A grande diversidade de florada e o comportamento fenológico da vegetação da Caatinga propiciam um escalonamento das floradas durante o ano, independente da estação, sempre havendo alguma espécie florescendo ao longo do ano (ALMEIDA-CORTEZ et al.) Vassourinha-deBotão: É uma planta conhecida popularmente como Vassourinha com nome científico Borreria verticillata, medindo de 30 a $60 \mathrm{~cm}$ de altura, presente em todo continente americano, incluindo todo o território brasileiro, em solos arenosos (LORENZI, 2000). Possui ciclo de vida perene, exclusiva reprodução por sementes, porte herbáceo, caule ramificado e raiz pivotante podendo alcançar grande profundidade no solo. Suporta solos ácidos e pobres em nutrientes e é vista como uma planta rústica (KISSMANN; GROTH, 2000). Suas inflorescências são constituídas por flores pequenas e com pétalas brancas.

É uma planta que possui um grande potencial apícola, sendo uma fonte de néctar muito importante para as abelhas (LIBERATO et al., 2016). Marmeleiro: é uma espécie de planta de porte arbóreo-arbustivo que floresce no Nordeste no início do período chuvoso. É grande fornecedora de néctar para as abelhas, principalmente na Caatinga. 0 mel proveniente dessa florada é favorecido por sua coloração, possuindo sabor e aroma muito apreciados (BENEVIDES et al., 2009). Seu nome científico é Cydonia oblonga, uma planta originada do Brasil, crescendo de forma silvestre, tendo início no Piauí e seguindo do Nordeste até Minas Gerais, abrangendo áreas desmatadas e formando grandes conjuntos relativamente homogêneos na Caatinga (MATOS, 1999). Mofumbo: é uma planta com registro na Bolívia, Paraguai e Brasil, com distribuição exclusiva na América do Sul (LOIOLA, 2009). No Brasil é nativa da Caatinga do Nordeste Brasileiro e do Pantanal Matogrossense, atingindo nesta região um porte arbóreo (LORENZI, 1999). É conhecida popularmente por Mofumbo, Cipoaba e Carne-de-vaca, com nome científico Combretum leprosum é uma planta medicinal, com função cicatrizante, sendo utilizada na prevenção de irritações cutâneas, em limpeza de feridas, e na contenção de hemorragias (PIETROVSKI et al., 2008). Suas folhas e a entrecasca do caule são usadas também em infusões como hemostático, sudorífico e calmante (MORS, RIZZINI \& PEREIRA, 2000).

\section{POLUIÇÃO AMBIENTAL}

Consideram-se como causadoras de poluição ambiental as atividades que, direta ou indiretamente, degradam o meio ambiente, prejudicando a saúde, afetando negativamente a biota, as condições sanitárias ambientais, lançando matéria ou energia em desacordo com os padrões de qualidade ambiental estabelecido (DERISIO, 2016). As formas de difusão da poluição, direta e indiretamente, provocam o deslocamento populacional ou o desequilíbrio social, intromissões nos sistemas biológicos naturais, como a diminuição da fotossíntese pela poluição atmosférica. Os poluentes concentram-se ao logo da cadeia alimentar, mesmo que estejam em pequenas concentrações no ambiente, podendo causar sérios desastres ecológicos (BHAVANI; SUJATHA, 2014; BRILHANTE, 1999; ROSA; MESSIAS; AMBROZINI, 2003). A poluição ambiental possui vários tipos difundindo-se no meio ambiente, como poluição atmosférica, poluição hídrica e poluição do solo (SIRVINSKAS, 2018). As formas de poluição (água, solo e ar) relacionam-se apresentando conseqüências negativas no controle de poluição. A poluição que atinge o solo é uma das mais graves, pois é no solo onde se inicia grande parte dos ciclos biogeoquímicos. Além disto, o solo influencia na distribuição das espécies de plantas (MISHRA; MOHAMMAD; ROYCHOUDHURY, 2016; ROSA; MESSIAS; AMBROZINI, 2003). A poluição do solo promove redução da produtividade ocasionada pela presença de poluentes que causam efeitos adversos nas propriedades físico-químicas e biológicas (MISHRA; MOHAMMAD; ROYCHOUDHURY, 2016; ROSA; MESSIAS; AMBROZINI, 2003; SINGER; 
SCHWALD, 1991). As inúmeras fontes de poluição do solo originam-se das atividades industriais que armazenam e manipulam produtos químicos gerando efluentes e resíduos, causando danos, por remoção da cobertura vegetal de áreas extensas (ROCCA, 2004).

Um dos principais impactos da agricultura no meio ambiente é a contaminação da água e do solo, sendo compreendido pela degradação da qualidade de águas subterrâneas e superficiais (ZEBARTH, 1999), causada pela expansão agrícola e da produção agroindustrial. Resíduos de fertilizantes e agrotóxicos são contaminantes agrícolas, pois suas aplicações podem atingir corpos d'água diretamente, através da água da chuva e da irrigação, ou indiretamente através da percolação, chegando aos lençóis freáticos (ARIAS, 2007).

Uma das formas de poluição industrial consiste na descarga de água quente derivada de sistemas de refrigeração industrial, aumentando a temperatura da água e reduzindo a taxa de metabolização dos organismos promovendo aumento na demanda de oxigênio (APINAN, 2000; OWA, 2014). A determinação de espécies metálicas em produtos apícolas, como o mel é realizada para assegurar a qualidade do alimento para o consumo, tendo em vista as concentrações dos metais presentes (BOGDANOV, 2006; CAMPOS et al., 2008; MENDES, 2003; PAULO et al., 2012; PHIPPS, 1995). BIOINDICADORES: São os organismos ou comunidades de organismos, cuja presença, quantidade e distribuição relacionam-se à magnitude de impactos ambientais em um ecossistema, permitindo a avaliação integrada dos efeitos ecológicos causados por múltiplas fontes de poluição (CALLISTO et al., 2002).

O biomonitoramento possui vantagens em relação aos métodos tradicionais de verificação dos níveis de poluição como: baixo custo de instalação e acompanhamento; ausência de aparelhos sofisticados de medição; eficiência no monitoramento de áreas amplas; e períodos longos de tempo e viabilidade de avaliar elementos químicos presentes em baixas concentrações no ambiente analisado (CARRERAS; PIGANATA, 2001; HIATT, 1999; SUMITA et al., 2003). Os bioindicadores não morrem por alterações que ocorrem no ambiente, mas respondem por meio de ações no comportamento ou metabólicas, indicando e refletindo alguma mudança no ambiente (ANDRÉA, 2008). Os bioindicadores podem ser ecológicos respondendo a perturbações e mudanças ambientais; bioindicadores ambientais são sensíveis à poluição e outros estresses e os de biodiversidade que indicam a riqueza taxonômica de espécies de uma comunidade (GERHARDT, 2002; SAULOVIĆ; BIOČANIN; RODRIGUEZ, 2001).

Os bioindicadores estão sendo usados em diversos estudos envolvendo degradação ambiental, pois são organismos que apresentam respostas significativas aos impactos antrópicos nos ecossistemas (BROTTO et al., 2014). Os Reinos Animalia e Plantae são compostos pelos organismos usados nestes estudos (SORVARI et al., 2007). Devido a sua grande diversidade e um amplo habitat serem importantes nos processos biológicos dos ecossistemas naturais considera-se os insetos como indicadores de impacto ambiental. 0 decréscimo no número de ordens, famílias e espécies de insetos diminui com o alto nível de antropotização no ambiente, gerando uma identificação rápida de determinado impacto (THOMANZINI et al., 2002). As abelhas ao realizarem o forrageamento em busca de alimento entram em contato com o ar contendo poluentes com materiais particulados que possuem metais pesados e essas partículas são aderidas nos pelos e por todo corpo das abelhas. Além do mais, na coleta do néctar e pólen, que podem estar contaminados pelas partículas por deposição atmosférica ou por solo e água, também contaminados, os insetos acabam levando esses poluentes para o interior das colméias (PORRINI et al., 2003, POHL 2009).

Atualmente o principal problema para apicultores é o envenenamento de abelhas (SOUSA et al., 2013). A apicultura é extremamente dependente das plantas, deixando as abelhas expostas aos poluentes liberados na natureza que acabam contaminando seus produtos (ORSI et al., 2004). 0 uso de pesticidas na agricultura, parasitas, infecções bacterianas, alterações do clima são algumas teorias que tentam explicar o desaparecimento em massa de abelhas (SANTOS, 2010; SOUSA et al., 2013).

Insetos que são importantes para o meio ambiente, na manutenção do equilíbrio ecológico, como borboletas, besouros, mosquitos e abelhas acabam sendo prejudicados pelo uso dos pesticidas usados para eliminar pragas nas plantações (SOUSA et al., 2013). Diminuição na riqueza de espécies, perda da diversidade dos organismos, redução da abundância e mortalidade são impactos que ocorrem por conta da elevação de contaminação do pólen por metais pesados, expostos em investigações de poluição por traços metálicos em abelhas (MORON et al., 2012). Inúmeros estudos citam como principal motivo de perda de espécies de polinizadores os metais pesados (KOSIOR et al., 2007), pois esses elementos são derivados dos locais de forrageamento, solo e flores e são transferidos as larvas e organismos nos ninhos causando intoxicação na colméia (SZCZESNA, 2007). 
O desaparecimento de animais polinizadores, em especial as abelhas, vem sendo relatado desde os anos de 1880, 1920 e 1960 (PAREJA et al., 2011). Mesmo apresentando uma grande importância para o meio ambiente, as abelhas estão sendo introduzidas em um processo de desaparecimento muito acelerado. Esse fato impossibilita a realização da polinização realizada pelas abelhas.

Uma das maiores influências que acarretam esse desaparecimento são as ações humanas como o desmatamento, uso desenfreado de agrotóxicos e queimadas (LEITE et al., 2016). 0 desmatamento e a poluição ambiental podem agir juntos ou separadamente, ao mesmo tempo ou em seqüência, podendo exercer mais efeito em algumas situações e menos em outras, porém o resultado é o desaparecimento das colônias (ARIOLI et al., 2017). A preocupação com o desaparecimento das abelhas vem aumentando, pois, muitos agricultores dependem dos serviços desses animais (LEITE et al., 2016). Muitos agricultores e polinizadores têm sofrido com o processo de industrialização e urbanização, tendo o homem como principal responsável pela transformação do ambiente das abelhas (SANTOS, 2010).

\section{CONTAMINANTES}

Os que mais afetam o ecossistema são os metais que realizam diversos processos que regulam os sistemas biológicos, detendo elevada afinidade por inúmeras moléculas biológicas (DNA, enzimas, proteínas, polipeptídios, aminoácidos) de extrema importância para vida, possibilitando que os íons sejam captados e absorvidos pelas células animais e vegetais (VAN ELDINAK, 1999; BENITE et al., 2007). Os metais são classificados de três formas: os que são denominados como elementos essenciais, necessários ao funcionamento do metabolismo biológico dos organismos, em nível traço, na ordem de miligrama, como Sódio (Na), Potássio (K), Ferro (Fe), Zinco (Zn), Cobre (Cu), Níquel (Ni) e Magnésio (Mg) (ULUOZLU et al., 2007). De outro modo, metais como $\mathrm{As}, \mathrm{Pb}, \mathrm{Cd}, \mathrm{Hg}, \mathrm{Al}, \mathrm{Ti}, \mathrm{Sn}$ e $\mathrm{W}$, são classificados como microcontaminantes e tóxicos. $\mathrm{O} \mathrm{Cr}, \mathrm{Zn}, \mathrm{Fe}, \mathrm{Co}, \mathrm{Mn}$ e Ni, são simultaneamente necessários aos organismos e microcontaminantes, tornando-se necessários em níveis traços, porém em níveis excessivos se tornam potencialmente tóxicos (OGA et al., 2008).

Os metais são componentes naturais da biosfera, um dos maiores e abundantes grupos de microcontaminantes, estando amplamente distribuídos no meio ambiente (INÁCIO, 2006). Classificados como substâncias inorgânicas, alguns estão localizados no solo, contaminando facilmente alimentos (BARRETO, 2013). Alguns metais são essenciais para o funcionamento do organismo, porém outros não desempenham nenhum papel (VAN et al., 2005). Os metais pesados são contaminantes causadores de imensa preocupação para saúde humana e animal sendo liberados por fontes naturais ou antrópicas e na maioria dos casos não se degradam e continuam por muito tempo no ambiente, gerando toxidade (PERUGINI et al., 2011). Os metais pesados apresentam diferenciadas formas de identificação e toxicidade, podendo ser poluentes das águas, solos e da atmosfera (ROSA, 2018). Os metais tornam-se contaminantes quando ingeridos em quantidades acima das necessárias e sua concentração nos alimentos é função das condições ambientais onde este foi produzido (MÍDIO E MARTINS, 2000).

Determinadas formas dos metais produzem efeitos tóxicos, logo, a toxicidade dos metais depende de sua forma química e estado de oxidação. Estes metais tóxicos são absorvidos pelo nosso corpo através de alimentos, água, inalação de ar poluído, uso de cosméticos e drogas (INSA, 2011; RAJESWARI; SAILAJA, 2014). A toxicidade de metais pode causar doenças crônicas, com sintomas de desordem mental, perda de memória, sensação de irrealidade, percepção distorcida, dor nos músculos, desordens gastrointestinais, problemas de visão, fadiga crônica e suscetibilidade a infecções por fungos (INSA, 2011). Cobre: é um elemento considerado como essencial para a maioria dos organismos vivos, participa do metabolismo celular, sendo o terceiro elemento de transição em maior abundância no organismo depois do $\mathrm{Zn}$ e do Fe (INÁCIO, 2006).

Através da ação das chuvas ou movimentação do solo, o cobre se encontra nas margens de rios e lagos, tornando-se um componente natural do solo. A maioria do cobre liberado para recursos hídricos encontra-se como material particulado (PEDROZO, LIMA, 2001). É um metal que em excesso pode desenvolver doenças e toxidade (CHAN et al., 1998), mas é essencial para inúmeras funções orgânicas, utilizado como co-fator de diversas enzimas celulares (PEDROZO, LIMA, 2001). Os sais de cobre, em caso de ingestão, são observados através dos sintomas que incluem dor abdominal, cefaléias, náuseas, vômitos, tonturas, diarréia, taquicardia, dificuldade respiratória, anemia hemolítica, hemorragia digestiva maciça, insuficiência hepática e renal e morte (BARCELOS, 2008). Zinco: é um elemento abundante da crosta terrestre, encontrado em minerais nas formas de sulfetos e carbonatos (DUARTE; PASQUAL, 2000); no ar, solo e água estando presente em todos os alimentos (ATSDR, 2005). Um metal que desempenha inúmeras funções bioquímicas no organismo, tornando-se um elemento mineral necessário em quantidades muito 
pequenas (KING et al., 2000). Este elemento atua como componente em diversas enzimas, participando da divisão celular, expressão genética, processos fisiológicos, transcrição genética e morte celular (MAFRA; COZZOLINO, 2004). Entretanto, por ser um elemento necessário, determinados sais de zinco podem prejudicar a vida e levar um indivíduo a morte (HEIN, 2003).

0 excesso de concentrações de Zinco é prejudicial, pois se encontra associado à supressão da resposta imune, diminuição da lipoproteína de alta densidade (HDL) e à redução das concentrações de cobre no plasma (JEN; YAN, 2010). A contaminação por Zinco pode ocorrer pelo uso de recipientes galvanizados. Recipientes de Cobre e seus compostos usados como pesticidas podem ser a origem de metais em quantidades indesejáveis no mel (SHILS et al., 2003). Ferro: encontra-se entre os 8 elementos mais abundantes da crosta terrestre, porém localiza-se em maior proporção como íon ferro. 0 elemento Ferro, na forma iônica oxidada é facilmente encontrado na natureza, em combinações especialmente com oxigênio em inúmeros tipos de minerais (CAVASSA, 2013). 0 Ferro é um micronutriente que realiza importantes funções no corpo humano, transportando e armazenando oxigênio, reações de liberação de energia e diversas outras reações metabólicas essenciais (PAIVA, 2000). Mesmo com uma grande importância para o sistema biológico, sua insolubilidade e reatividade acarretam problemas de baixa disponibilidade e toxicidade (EKOSSE; FOUCHE, 2006).

0 ar, água e solo sofrem sérios efeitos por fontes antropogênicas de Ferro, através da indústria de aço e ferro prejudicando o meio ambiente com emissões de gases e material particulado, e processamento de água com matéria orgânica (DOUSHANOV, 2010). Magnésio: é um dos elementos em maior concentração no organismo e no corpo humano, desempenhando um papel importante como co-fator para mais de 300 reações enzimáticas, relacionadas com a síntese de DNA, RNA e protéica (SUGIMOTO, 2012; BAAIJ et al., 2012). Atuando com principal função, associado ao ATP, na ativação ou desativação de vias de transdução de sinal, por exemplo, na sinalização da insulina (WOLF; TRAPANI, 2008).

O magnésio é absorvido como íon bivalente, compondo a molécula de clorofila. 0 teor deste mineral nas plantas varia de 2 a $4 \mathrm{~g}$ (SENGIK, 2003). Crescimento de plantas e alteração da colonização são características da alta concentração de magnésio no solo, deteriorando propriedades químicas e biológicas do mesmo (LUCAS; DAVIS, 1961). Manganês: é um elemento que se encontra na natureza combinado com diversos outros, constituindo minerais, geralmente, óxidos. Não se sabe da sua existência na forma metálica, mesmo estando muito disperso nas rochas (HAROLD E TAYLOR, 1994). Um metal que pertence ao grupo dos elementos de transição (SAMPAIO, 2008), apresentando algumas características, como variação nas formas e estados de oxidação e formando vários compostos coloridos e paramagnéticos (PRATES, 2011). Esse mineral está presente nos alimentos, água e no ar que respiramos, deixando os seres humanos expostos. É importante na manutenção da vida, caso ocorra carência nos humanos, causa perda de peso, fragilidades nos ossos, dermatite, degeneração do ovário ou testículos e náuseas. Seu excesso pode causar diminuição do crescimento e distúrbios ao nível do esqueleto, aumento da pressão sanguínea, depressão da atividade das glândulas mamárias e anormalidades nas mitocôndrias (DAMIÃO \& RAMOS, 2004/2005). Cálcio: é o quinto elemento mais abundante da crosta terrestre, fazendo parte de diversos minerais, disseminados por todo o planeta (LEE, 1999, ROSA; MESSIAS; AMBROZINI, 2003). É um metal de baixa dureza, prateado, que reage facilmente com o oxigênio do ar e com a água, sendo encontrado principalmente como constituinte de rochas, como calcário, não achado isoladamente na natureza (RODRIGUES E ÁVILA, 2017). 0 cálcio na planta é absorvido como íon bivalente, possuindo um papel muito importante no desenvolvimento das raízes, necessário na translocação e armazenamento de carboidratos e proteínas. Quantidade de nutrientes, grau de saturação no complexo de troca e a relação com outros cátions do complexo coloidal, são fatores que podem afetar a disponibilidade de cálcio nas plantas (SENGIK, 2003). 


\section{MATERIAIS E MÉTODOS}

\section{Origem das amostras:}

Os méis analisados, foram obtidos através de apicultores (mel - 1, mel - 2, mel- 3) e meliponicultores (mel - 4, mel - 5, mel - 6). As amostras foram devidamente identificadas e conservadas. A tabela 2 abaixo indica a origem das amostras de mel analisadas neste trabalho.

Tabela 2 - Origem das amostras de mel cearenses

\begin{tabular}{|c|c|c|c|}
\hline Amostra & Florada & Local de origem & Abelha produtora \\
Mel -1 & Silvestre & Santana do Cariri & Apis Mellifera \\
Mel - 2 & Silvestre & Cascavel & Apis Mellifera \\
Mel - 3 & Vassourinha-de-Botão & Trairi & Apis Mellifera \\
Mel - & Marmeleiro & Beberibe & Melipona Subnitida \\
Mel -5 & Silvestre & Aracati & Melipona Subnitida \\
Mel -6 & Mofumbo & Aquiraz & Melipona Subnitida \\
\hline
\end{tabular}

Fonte: Elaborado pela autora, 2019.

\section{CINZAS E MINERAIS}

Para essa análise usou-se cápsula de porcelana, previamente aquecida em estufa a $100^{\circ} \mathrm{C}$, resfriada em dessecador com sílica até a temperatura ambiente. Em seguida foi pesada e anotou-se a tara da cápsula de porcelana. Pesou-se $5 \mathrm{~g}$ de mel e acondicionou-se em cadinho de porcelana. 0 cadinho com a amostra foi posto sobre placa de aquecimento a $350^{\circ} \mathrm{C}$, em capela de exaustão, até cessar a emissão de fumaça. Em seguida, levou-se para mufla (marca QUIMIS ${ }^{\circledR}$ ) a $600^{\circ} \mathrm{C}$ por $5 \mathrm{~h}$. Resfriou-se em seguida o cadinho, em dessecador, e pesou-se com intervalos de 1h, até massa constante (BRASIL, 2000). A análise foi realizada em triplicata. $O$ valor obtido após a calcinação foi usado para o cálculo das cinzas, usando a equação abaixo (BRYANT; MCCLEMENTS, 2000).

$$
\% \text { Cinzas }=\frac{\text { Massa das cinzas }(\mathrm{g})}{\text { Massa da } \operatorname{amostra}(\mathrm{g})} \times 100
$$

0 resíduo das cinzas foi solubilizado em $1 \mathrm{~mL}$ de ácido nítrico - $\mathrm{HNO}_{3} 8 \mathrm{Me}$ filtrado para obtenção das cinzas solúveis. Depois se transferiu para um balão volumétrico de 10,00??? e este foi aferido com água destilada. A partir da solução das cinzas, foram feitas leituras em um espectrofotômetro de absorção atômica por chama (FAAS) de modelo AA-7000 Atomic Absorption Spectrophotometer de marca Shimadzu, para a determinação do teor dos constituintes minerais (DIONÍSIO, et al., 2011) Ferro, Magnésio, Manganês, Zinco, Cobre e Cálcio, nas diferentes amostras de méis. As condições operacionais do FAAS também foram verificadas, de acordo com a tabela 3.

Tabela 3 - Relação das condições operacionais do FAAS para cada mel analisado

\begin{tabular}{|c|c|c|c|c|c|c|}
\hline $\begin{array}{c}\text { Condições operacionais } \\
\text { do FAAS }\end{array}$ & $\mathrm{Cu}$ & $\mathrm{Zn}$ & $\mathrm{Mn}$ & $\mathrm{Fe}$ & $\mathrm{Ca}$ & $\mathrm{Mg}$ \\
\hline $\begin{array}{l}\text { Comprimento da onda } \\
\text { (nm) }\end{array}$ & 324,8 & 213,9 & 279,5 & 248,3 & 422,7 & 285,2 \\
\hline Largura da fenda (nm) & 0,7 & 0,7 & 0,2 & 0,2 & 0,7 & 0,7 \\
\hline $\begin{array}{l}\text { Corrente da lâmpada } \\
\text { (mA) }\end{array}$ & 8,0 & 10,0 & 10,0 & 12,0 & 10,0 & 8,0 \\
\hline $\begin{array}{c}\text { Vazão do acetileno } \\
\text { (L/min) }\end{array}$ & 1,8 & 2,0 & 2,0 & 2,2 & 2,0 & 1,8 \\
\hline Corretor de fundo & - & $\begin{array}{l}\text { Lâmpada } \\
\text { de Deutério }\end{array}$ & $\begin{array}{c}\text { Lâmpada } \\
\text { de Deutério }\end{array}$ & $\begin{array}{c}\text { Lâmpada } \\
\text { de Deutério }\end{array}$ & $\begin{array}{c}\text { Lâmpada } \\
\text { de Deutério }\end{array}$ & $\begin{array}{c}\text { Lâmpada } \\
\text { de Deutério }\end{array}$ \\
\hline
\end{tabular}




\section{RESULTADOS E DISCUSSÃO}

\section{Cinzas}

Normalmente o mel possui, um baixo teor de cinzas, que varia por conta do material recolhido pelas abelhas durante a colheita de néctar (RODRÍGUEZ et al., 2005), pela origem botânica, solo e alterações climáticas (VENTURINI, 2007). Os valores obtidos expressam a presença quantitativa de minerais no mel (FINOLA et al., 2007). Entre os metais já encontrados no mel, estão o cobre, ferro, manganês, magnésio, potássio, silício, zinco, radio, estanho, alumínio, ósmio, titânio e chumbo (PAMPLONA, 1989). Um teor extremamente alto de cinzas indica que o mel sofreu adulteração (VENTURINI, 2007). De acordo com a legislação, o teor máximo de cinzas permitidos em méis de flores é de 0,6\%, tornando possível a verificação de irregularidades no produto apícola (BRASIL, 2000). Os teores de cinzas estão contidos na tabela 4 .

Tabela 4 - Teor percentual de cinzas

\begin{tabular}{|c|c|c|}
\hline Amostra & Média (\%) & Desvio padrão \\
\hline MEL - 1 & 0,15 & 0,01 \\
\hline MEL - 2 & 0,28 & 0,01 \\
\hline MEL - 3 & 0,18 & 0,02 \\
\hline MEL - 4 & 0,06 & 0,01 \\
\hline MEL - 5 & 0,03 & 0,03 \\
\hline MEL - 6 & 0,01 & 0,01 \\
\hline
\end{tabular}

Fonte: Elaborado pela autora, 2019.

Todas as amostras neste trabalho estão em conformidade com a legislação, visto que os méis apresentaram teores abaixo de $0,6 \%$. Os teores de cinzas nas amostras analisadas de méis variaram de $0,28 \%$ a $0,01 \%$. Em destaque se encontra o MEL - 2 que apresentou o maior teor de cinzas entre todas as amostras e o MEL - 6 que apresentou o menor teor e isso se deve a variação de aspectos ambientais de acordo com Karabagias et al. (2014). Méis da região Nordeste analisados por Sodré et al. (2007), exibiram valores que variaram entre 0,0 a $0,4 \%$. Rodrigues et al. (2005) realizaram um estudo com 10 amostras de méis, oriundos do estado da Paraíba obtendo valores variando entre 0,01 e 0,03\%. Finco (2010) analisando 24 amostras de méis de diversas floradas obteve valores variando de 0,01 a 0,30\%, porcentagens muito parecidas com as que constam neste trabalho.

Marchini e Otsuk (2005) analisando amostras de mel apresentaram valores de cinzas dentro do limite estabelecido pela legislação, semelhantes aos valores encontrados nas amostras analisadas que estão em conformidade com a Legislação Brasileira. As amostras MEL - 1, MEL - 2 e MEL - 3, são méis produzidos por abelhas Apis mellifera e apresentaram maiores teores em relação as amostras MEL - 4, MEL - 5 e MEL - 6 que são de Melipona subnitida, isso explica o fato de todos os méis de Apis mellifera serem escuros e os méis de Melipona subnitida serem mais claros, pois, os minerais influenciam diretamente na coloração do mel, sendo encontrados em maiores concentrações nos méis mais escuros quando comparados aos méis claros (STRAMM, 2011; ALQARNI et al, 2014).

\section{Minerais}

As cinzas de um alimento são expressas através do resíduo inorgânico resultante da queima de matéria orgânica da amostra. Geralmente possui grandes quantidades de $\mathrm{K}, \mathrm{Na}$, $\mathrm{Ca}$ e $\mathrm{Mg}$ e pequenas quantidades de $\mathrm{Al}, \mathrm{Fe}, \mathrm{Cu}, \mathrm{Mn}$ e $\mathrm{Zn}$ e demais elementos (PARK \& ANTONIO, 2006). 0 teor de minerais que presentes no mel, expressos através do teor de cinzas, é muito utilizado como critério de qualidade e está diretamente relacionado com sua origem botânica e geográfica (MARCHINI et al., 2004). De acordo com White (1975) o mel possui uma série de minerais. A determinação da concentração de minerais é realizada por Espectrometria de Absorção Atômica em chama (FAAS). Pelo fato de ter uma boa eficiência analítica, a técnica de FAAS é a mais utilizada em análises de metais em alimentos (LÓPES-GARCIA et al., 1999). Verifica-se na Tabela 5 os valores médios encontrados nas amostras analisadas, variando para todas as amostras de 0,02 - 0,249 mg/100g para Zinco, 0,0 - 0,02 mg/100g para Manganês, 0,06 - 0,42 mg/100g para Ferro, 47,90 - 210,88 mg/100g para Cálcio e 0,55 - 1,50 mg/100g para Magnésio, não sendo detectado o elemento Cobre em nenhuma das amostras. Observou-se que todos os méis da abelha Apis mellifera obtiveram resultados de concentrações de minerais maiores em relação aos méis da abelha Melipona subnitida. 
Tabela 5 - Teores médios dos minerais determinados nos méis em mg/100g.

\begin{tabular}{|l|c|c|c|}
\hline \multicolumn{1}{|c|}{ Amostras/Região } & \multicolumn{2}{c|}{ Zn } & Mn \\
\hline MEL 1 - Santana do Cariri & 0, & $0,13 \pm 0,10$ & $0,0,104 \pm 0,005$ \\
\hline MEL 2 - Cascavel & $0,-$ & $0,249 \pm 0,03$ & $0,0,112 \pm 0,05$ \\
\hline MEL 3 - Trairi & $0,-$ & $110,165 \pm 0,01$ & $0,0,102 \pm 0,003$ \\
\hline MEL 4 - Beberibe & $0,-$ & $0,06 \pm 0,01$ & 0, \\
\hline MEL 5 - Aracati & $0,-$ & $0,02 \pm 0,01$ & $0,0,021 \pm 0,02$ \\
\hline MEL 6 - Aquiraz & $0, \quad-$ & $0,06 \pm 0,01$ & 0, \\
\hline \multicolumn{1}{|c|}{ Amostras/Região } & Fe Ca & Mg \\
\hline MEL 1 - Santana do Cariri & $0,0,25 \pm 0,02$ & $60,9 \pm 6,50$ & $1,40 \pm 0,07$ \\
\hline MEL 2 - Cascavel & $0,0,42 \pm 0,01$ & $210,88 \pm 14,97$ & $1,50 \pm 0,08$ \\
\hline MEL 3 - Trairi & $0,0,16 \pm 0,04$ & $56,19 \pm 5,22$ & $1,37 \pm 0,04$ \\
\hline MEL 4 - Beberibe & $0,0,06 \pm 0,01$ & $49,93 \pm 3,28$ & $0,59 \pm 0,07$ \\
\hline MEL 5 - Aracati & $0,08 \pm 0,01$ & $47,90 \pm 1,56$ & $0,55 \pm 0,09$ \\
\hline MEL 6 - Aquiraz & $0, \quad-$ & $50,82 \pm 3,50$ & $0,60 \pm 0,07$ \\
\hline
\end{tabular}

Fonte: Elaborado pela autora, 2019.

Nas amostras analisadas, observou-se que os maiores valores de minerais foram de Ca e Mg que pode ser explicado pelo fato do Cálcio e Magnésio serem classificados como macronutrientes nas plantas, essenciais no ciclo de vida, sendo absorvidos em maior quantidade que os demais elementos (FERNANDES, 2006), tornando-se abundantes naturais em solos tropicais, estando em maiores concentrações, porém Cálcio e Magnésio não são considerados contaminantes de mel de abelhas (BENITES et al., 2010; TISDALE et al., 1993). Ca ficou em primeiro lugar em concentrações em todas as amostras analisadas, em especial o MEL - 2 que apresentou 210,88 mg/100g de Cálcio. Isso se deve a correção de níveis de Cálcio através da aplicação de alguns adubos que possuem este elemento, ocorrendo a elevação do mesmo e também de solos calcários presentes no Ceará (SENGIK, 2003). Marchini et al (2005) obtiveram valores de 1 a 202 $\mathrm{mg} / 100 \mathrm{~g}$ para mel da florada silvestre, valores próximos aos encontrados nesse trabalho.

Verifica-se que o MEL - 2 apresentou os maiores valores de concentrações para minerais. Quanto à concentração de contaminantes, todas as amostras se adequaram à Legislação Brasileira (BRASIL, 1965; BRASIL, 1978; BRASIL, 1998; BRASIL, 2008). O Cobre é um elemento muito importante e essencial à fotossíntese, na produção de clorofila nas plantas, possuindo maior disponibilidade em solos no meio ácido (SENGIK, 2003).

De acordo com a Legislação Brasileira o valor máximo estabelecido para este elemento é de 10,00 mg/100g. 0 Cobre dentre os minerais analisados, foi o elemento que não foi detectado dentre as amostras analisadas. Amostras analisadas por Torrenza (2008) que foram produzidas nos estados do Ceará e Piauí, obtiveram médias encontradas para as amostras 0,191-0,452 mg/100g para cálcio, traços - 0,104 $\mathrm{mg} / 100 \mathrm{~g}$ para cobre, 0,1-0,366 mg/100g para ferro, traços de magnésio $(<0,01 \mathrm{mg} / 100 \mathrm{~g}) ; 0,024-0,465$ $\mathrm{mg} / 100 \mathrm{~g}$ para manganês, 0,158- 5,59 mg/100g para potássio, 0,101-2,002 $\mathrm{mg} / 100 \mathrm{~g}$ para sódio, e traços0,317 mg/100g para zinco. Observa-se que para os elementos Fe e Mn, os resultados foram semelhantes aos contidos neste trabalho. Üren et al., (1998) analisaram diferentes méis da Turquia, determinando Fe, $\mathrm{Cu}, \mathrm{Zn}, \mathrm{Mn}, \mathrm{Ca}, \mathrm{Mg}$ e K pela mesma técnica utilizada neste trabalho, obtendo valores variando de 4,9-19,7 $\mathrm{mg} / 100 \mathrm{~g}$ para Fe; 0,350-1,24 mg/100g para Cu; 0,977-1,84 mg/100g para Zn; 0,309-0,752 mg/100g para Mn; 19,5-79,0 mg/100g para Ca; 21,0-56,1mg/100g para Mg, e 281-2196 mg/100g para K.

Os valores de variação de Ca e Zn foram parecidos com os obtidos neste trabalho. Observa-se que em todas as amostras analisadas, os méis da abelha Apis mellifera apresentaram maiores valores em relação aos méis da abelha Melipona subnitida, isso se explica pelo fato da apicultura está sendo cada vez mais praticada em ambientes mais urbanizados, deixando a Apis exposta mais facilmente a diversos tipos de contaminantes ao realizar a atividade de forrageamento em busca de alimento, percorrendo diversos setores do ambiente, contaminando-se e indiretamente contaminando seus produtos apícolas (WOLF; REIS; SANTOS, 2008). 


\section{CONCLUSÃO}

As concentrações nas amostras de méis analisados encontram-se dentro do valor permitido de variação pela Legislação Brasileira. A concentração de minerais no mel depende da concentração dos mesmos no solo, nas plantas e de fatores externos. Cálcio e Magnésio são nutrientes essenciais para as plantas, expondo-se como os minerais de maiores concentrações nas amostras analisadas. Neste trabalho, houve comprovação de concentrações elevadas de Ca, porém não sendo considerado um contaminante. Dentre as amostras analisadas, todos os méis da abelha Apis mellifera apresentaram concentrações de minerais maiores que os méis da abelha Melipona subnitida, concluindo-se que por conta de fatores como uma maior área de forrageamento da Apis, (a apicultura está sendo cada vez mais realizada em locais urbanos) haverá uma maior concentração de minerais no produto deste tipo de abelha. Portanto, fatores como a região, florada, solo, dimensão da área de forrageamento das abelhas, causam variações nas concentrações de minerais no mel, tornando-se assim um produto bastante complexo.

\section{REFERÊNCIAS}

[1] ALMEIDA, M. C. de; LAROCA, S.Trigona spinipes (Apidae, Meliponinae): taxonomia, bionomia e relações tróficas em áreas restritas.Acta Biológica Paranaense, v.17, n.1, p.67-108, 1998.

[2] ALMEIDA-ANACLETO, Daniela de. Recursos alimentares, desenvolvimento das colônias e características físico químicas, microbiológicas e polínicas de mel e cargas de pólen de meliponíneos, do município de Piracicaba, Estado de São Paulo. 2007. Tese de Doutorado. Universidade de São Paulo.

[3] ALMEIDA-CORTEZ, J. S.; CORTEZ, P. H. M.; FRANCO, J. M. V.; UZUNIAN, A. Caatinga. Coleção Biomas do Brasil São Paulo: HARBRA. 2007. 64p.

[4] ALQARNI, A. S., OWAYSS, A. A., MAHMOUD, A. A., \& HANNAN, M. A. (2014). Mineral content and physical properties of local and imported honeys in Saudi Arabia. Journal of Saudi Chemical Society. 18, 618-625.

[5] ALVAREZ-SUAREZ, J.M., TULIPANI, S., ROMANDINI, S., BERTOLI, E, BATTINO, M., 2010. Contribution of honey in nutrition and human health: a review. Mediterr. J. Nutr. Metab. 3, 15-23.

[6] ANDRÉA, Mara Mercedes de. Bioindicadores ecotoxicológicos de agrotóxicos. 2008.

[7] APINAN, V. Agriculture's influence on water quality in lower Northeastern Thailand. Water Quality management and control of water pollution. Water Reports 21, Food and Agriculture Organization of the United Kingdom. Rome. p.175-180, 2000.

[8] ARIAS, Ana Rosa Linde et al. Utilização de bioindicadores na avaliação de impacto e no monitoramento da contaminação de rios e córregos por agrotóxicos. Ciência \& Saúde Coletiva, v. 12, p. 61-72, 2007.

[9] ARIOLI, C. J. et al. Polinizadores em perigo: por que nossas abelhas estão desaparecendo? In: Embrapa Uva e Vinho-Artigo em anais de congresso (ALICE). In: Simpósio Internacional Ciência, Saúde e Território, 4., 2017, Lages, SC. Anais... Alimentos seguros, nutritivos e suficientes. Lages, SC: UNIPLAC, 05 a 07 de jun. 2017.

[10] AROUCHA, Edna Maria Mendes et al. QUALIDADE DO MEL DE ABELHA PRODUZIDOS PELOS INCUBADOS DA IAGRAM E COMERCIALIZADO NO MUNICIPIO DE MOSSORÓ/RN. Revista Caatinga, v. 21, n. 1, 2008.

[11] ATSDR. Toxicological profile for zinc. U.S. Department of Health and Human Services, Public HealthService, Agency for Toxic Substances and Disease, Atlanta, GA, 2005.

[12] AZEREDO, L. C.; AZEREDO, M. A. A.; DUTRA, V. M. L. Protein contents and physicochemical properties in honey samples of Apis mellifera of different floral origins. Food Chemistry, n. 80, p. 249-254, 2003.

[13] BAAIJ, J.H.F.; HOENDEROP, J.G.J.; BINDELS, R.L.M. Regulation of magnesium balance: lessons learned from human genetic disease. Clin Kidney j, v.5 [Suppl 1], 0.15-24, 2012.

[14] BARCELOS, Tânia Dalila de Jesus. Cobre. 2008. Tese de Doutorado. Universidade da Beira Interior.

[15] BENEVIDES, S. D.; CARVALHO, G. F. Levantamento da flora apícola presente em áreas de caatinga do município de Caraúbas - RN. Sociedade e Território, Natal, v.21, no 1-2, p-44, 2009.

[16] BENITE, A. M. C.; MACHADO, S. P.; BARREIRO, E. J. Considerações sobre a química bioinorgânica. Revista eletrônica de Farmácia, 4, 131-142.2007.

[17] BENITES, V de M.; CARVALHO, M.; RESENDE, A. V de.; \& POLIDORO, J. C.; BERNARDI, A. C de C.; OLIVEIRA, F. A de. Potássio, cálcio e magnésio na agricultura brasileira / Potassim, calcium and magnesium in Brazilian agriculture. p. 100-130,2010. 
[18] BHAVANI, P.; SUJATHA. B. Impact of toxic metals leading to environmental pollution. National Seminar on Impact of Toxic Metals, Minerals and Solvents leading to Environmental Pollution. Journal of Chemical and Pharmaceutical Sciences. p. 70-72, 2014.

[19] BIENEFELD, K.; PIRCHNER, F. Heritabilities for several colony traits in the honeybee (Apis mellifera carnica).Apidologie, v. 21, n. 3, p. 175-183, 1990.

[20] BOGDANOV, S. Contaminants of bee products. Apidologia, v. 37, n. 1, p. 1-18, 2006.

[21] BOGDANOV, S.; HALDIMANN, M.; LUGINBÜHL; GALLMANN, P. Minerals in honey: environmental, geographical and botanical aspects. Journal of Apicultural Research, v. 46, n. 4, 2007.

[22] BRASIL, Ministério da Saúde. Decreto no 55871 de 26 de maço de 1965. Modifica o Decreto no 50.040, de 24 de janeiro de 1961, referente a normas reguladoras do emprego de aditivos para alimentos, alterado pelo Decreto $\mathrm{n}^{\circ}$ 691, de 13 de março de 1962. Diário Oficial [da República Federativa do Brasil ], Brasília, 09 de abril de 1965.

[23] BRASIL, Ministério da Saúde. Resolução no 12 de 24 de julho de 1978. Normas Técnicas Especiais - Mel. Diário Oficial [da República Federativa do Brasil ], Brasília, 24 de julho de 1978.

[24] BRASIL, Ministério da Saúde. Portaria no 685 de 27 de agosto de 1998. Princípios Gerais para o Estabelecimento de Níveis Máximos de Contaminantes Químicos em Alimentos - Limites máximos de tolerância para contaminantes inorgânicos. Diário Oficial [da República Federativa do Brasil ], Brasília, 28 de agosto de 1998.

[25] BRASIL, Ministério da Agricultura, Pecuária e Abastecimento. Instrução Normativa no 11 de 20 de outubro de 2000. Regulamento Técnico de Identidade e Qualidade do Mel. Diário Oficial [da República Federativa do Brasil ], Brasília, 23 de outubro de 2000.

[26] BRASIL, Ministério da Agricultura, Pecuária e Abastecimento. Instrução Normativa no 10 de 14 de abril de 2008. Programa Nacional de Controle de Resíduos em Produtos de Origem Animal. Diário Oficial [da República Federativa do Brasil ], Brasília, 17 de abril de 2008.

[27] BRASIL. Ministério da Agricultura e do Abastecimento. Gabinete do Ministro. AprovaRegulamento técnico de identidade e qualidade do mel. Instrução Normativa no 11, de 20 de outubro de 2000. Diário Oficial [da] República Federativa do Brasil, Brasília, Seção 1, p. 07, 2000.

[28] BRILHANTE, O. M. Gestão e avaliação de risco em saúde ambiental. Rio de Janeiro: FIOCRUZ, 1999. 155 p.

[29] BRUENING, Humberto. Abelha Jandaíra. 3. Ed. Natal, RN: SEBRAE/RN, 2006. 138 p.

[30] BRYANT, C. M.; MCCLEMENTS, D. J. Influence of sucrose on NaCl induced gelation of heat denatured whey protein solutions. Food Research International, n. 33, p. 649-653, 2000.

[31] CALLISTO, M.; GONÇALVES, J.F.Jr. A vida nas águas das montanhas. Ciência Hoje 31 (182): 68-71. 2002.

[32] CAMARGO, J. M. F.; PEDRO, S. R. M. Meliponini Lepeletier, 1836. In: MOURE, J. S. et al. (Ed.). Catalogue of Bees (Hymenoptera, Apoidea) in the Neotropical Region.Curitiba: Sociedade Brasileira de Entomologia, 2007. p. $272-578$.

[33] CAMARGO, R. C. R., PEREIRA F. M., LOPES M. T. R., WOLFF, L. F. Mel: Características e Propriedades. Teresina. 30 P., 2006.

[34] CAMPOS, M. G. R.; BOGDANOV, S.; ALMEIDA-MURADIAN, L. B.; SZCZESNA, T.; MANCEBO, Y.; FRIGERIO, C.; FERREIRA, F. Pollen composition and standardisation of analytical methods. Journal of Apicultural Research and Bee World,v. 47, n. 2, p.156-163, 2008.

[35] CARRERAS, H. A.; PIGNATA, M L. Comparison among air pollutants, meterological conditions and some chemical parameters in the transplanted lichen Usnea amblyoclada. Environmental Pollution, v.111, p45-52, 2001

[36] CARVALHO, C.A.L. de; MARCHINI, L.C.; SODRÉ, G. da S. et al. Características físico-químicas de amostras de méis da Bahia: 1. Porcentagem de cinzas. In: CONGRESSO BAIANO DE APICULTURA, 1., Salvador, 2000. Anais. Salvador: Editora UESC, 2000. p.105.

[37] CARVALHO, Carlos A. L. et. al. Mel de abelha sem ferrão: contribuição para a caracterização físico-química. Cruz das Almas: UFBA/SEAGRI, 2005.

[38] CARVALHO, R. M. A.; MARTINS. C. F.; MOURÃO, J. S. Meliponiculture in Quilombola communities of Ipiranga and Gurugi, Paraíba state, Brazil: an ethnoecological approach. Journal of Ethnobiology and Ethnomedicine, v. 10, n. 3, p. 1-12, Jan/2014.

[39] CAVASSA, ALIETH S. P. FERRO - Da explosão de supernovas ao aço e hemoglobina.2013. Universidade Estadual de Campinas.

[40] CHAN, S.; GERSON, B.; SUBRAMANIAM, S. The role of copper, molybdenum, selenium and zinc in nutrition and health. Clinics in Laboratory Medicine, Philadelphia, v. 18, n.4, p. 678-685, 1998.

[41] CHOW, CrM et al. LCR-mediated, long-term tissue-specific gene expression within replicating episomal plasmid and cosmid vectors. Gene Therapy, v. 9, n. 5, p. 327, 2002. 
[42] CICCO, L. H. S. de, 2007; As abelhas e a história. Disponível em: http://www.saudeanimal.com.br/abelha0.htm, acessado em: 17/03/2019.

[43] CORTÉZ, M.E.; VIGIL, P.; MONTENEGRO, G. The medicinal value of honey: a review on its benefits to human health, with a special focus on its effects on glycemic regulation. Ciencia e Investigación Agraria, v.38, p. 303-317, 2011.

[44] CRAMP, D. A practical manual of beekeeping: How to keep bees and develop your full potential as an apiarist. Oxford, UK: How to books, 2008.

[45] DAMIÃO, A. \& RAMOS, A. Manganês.Trabalho realizado no âmbito da disciplina de Toxicologia e Análises Toxicológicas I no ano letivo 2004/05. Faculdade de Farmácia da Universidade do Porto, Portugal. Disponível em: http://www.ff.up.pt/toxicologia/monografias/ano0405/manganes/manganes.htm. Acesso em abril de 2019.

[46] DANFORTH, B. N.; SIPES, S.; FANG, J.; BRADY, S. G. The history of early bee diversification based on five genes plus morphology. Proceedings of the National Academy of Sciences of United States of America. v. 103, n. 41, p. 1511815123, 2006.

[47] DERISIO, José Carlos. Introdução ao controle de poluição ambiental. Oficina de Textos, 2016.

[48] DIONÍSIO, A.G.G.; DE JESUS, A. M. D.; AMAIS, R. S.; DANOTI, G. L.; MIRANDA, K. A.; GUERRA, M. B. B. ; NÓBREGA, J. A.; PEREIRA-FILHO, E. R. Old and New Flavors of Flame (Furnace) Atomic Absorption Spectrometry. International Journal of Spectroscopy, 2011.

[49] DOUSHANOV, D.L. Control of Pollution in the Iron and Steel Industry. Encyclopedia of Life Support Systems (EOLSS), v.8, p.1-5, 2010.

[50] DUARTE, R. B. de A. Histórias de Sucesso: Agronegócios - Apicultura. Brasília: SEBRAE, 2006.

[51] DUARTE, R.; PASQUAL, A. Avaliação do cádmio (Cd), chumbo (Pb), níquel (Ni) e zinco (Zn) em solos, plantas e cabelos humanos. Energia na Agricultura, Botucatu, v.15, n.1, p.46-58, 2000.

[52] EKOSSE, G. I. E.; FOUCHE, P. S. Environmental association of iron minerals and iron concentrations in soils close to abandoned manganese mine - a multivariate analytical approach. Journal of Applied Sciences and Environmental Management, v. 10, n.1, p. 31. - 36, 2006.

[53] FELIX, Jânio Angelo. Perfil zootécnico da meliponicultura no estado do Ceará, Brasil. Dissertação (Mestrado em Zootecnia: Abelhas e Polinização). Universidade Federal do Ceará (UFC), Centro de Ciências Agrárias, Departamento de Zootecnia, Fortaleza, CE, 2015.

[54] FERNANDES, CAROLINA; CORÁ, JOSÉ EDUARDO; BRAZ, LEILA T. Desempenho de substratos no cultivo do tomateiro do grupo cereja. Horticultura brasileira, p. 42-46, 2006.

[55] FINCO, F. D. B. A.; MOURA, Luciana Learte; SILVA, Igor Galvão. Propriedades físicas e químicas do mel de Apis mellifera L. Ciênc. e Tecnol. de Aliment, v. 30, n. 3, p. 706-712, 2010.

[56] FINOLA, M. S.; LASAGNO, M. C.; MARIOLI, J. M. Microbiological and chemical characterization of honeys from central Argentina.Food Chemistry, Amsterdam, v.100, p. 1649-1653, 2007.

[57] FREITAS, B.M. A.Vida das abelhas. Fortaleza: UFC.Craveiro \& Craveiro, 1999.

[58] GERHARDT, A. Bioindicator species and their use in biomonitoring. Environmental Monitoring I. Encyclopedia of Life Support Systems (EOLSS), Developed under the Auspices of the UNESCO. Oxford: Eolss Publishers; 2002.

[59] HAROLD A. e TAYLOR JR. (1994). Manganese minerals. In: Industrial Minerals and Rocks, 6th Edition, D. D. Carr (Senior Editor), Society of Mining, Metallurgy, and Exploration, Inc. Littleton, Colorado, 1196p., p. 655-660.

[60] HEIN, M. S. Cooper deficiency anemia and nephrosis in zinc-toxity: a case report. South Dakota Journal of Medicine, Sioux Falls, v. 56, n.4, p143-147, 2003.

[61] HERNÁNDEZ, O. M.; FRAGA, J. M. G.; JIMÉNEZ, A. I.; JIMÉNEZ, F.; ARIAS, J. J. Characterization of honey from the Canary Islands: determination of the mineral content by atomic absorption spectrophotometry. Food Chemistry, Amsterdam, v. 93, p. 449- 458, 2005.

[62] HIATT, M.H. Leaves as na indicator exposure airborne volatile organic compounds. Environmental Science \& Techonoly, v.33, p.4126-4133, 1999.

[63] INÁCIO, Alan Ferreira et al. Metalotioneína e metais em Geophagus brasiliensis-Acará. 2006. Tese de Doutorado.

[64] INSA. Hazardous metals and minerals pollution in India. Indian National Science Academy. New Delhi, 2011.

[65] IOANNIDOU, M. D,; ZACHARIADIS, G. A.; ANTHEMIDIS, A. N.; STRATIS, J. A. Direct determination of toxic trace metals in honey and sugars using inductively coupled plasma atomic emission spectrometry. Talanta, Amsterdam, $\mathrm{v}$. 65 , n. 1, p. 92- 97, 2005. 
[66] JEN, M.; YAN, A.C. Syndromes associated with nutritional deficiency and excess. Clin Dermatol., v.28, n.6, p.669-85, nov./dez. 2010

[67] KARABAGIAS, I. K.; BADEKA, A.; KONTAKOS, S.; KARABOURNIOTI, S.; KONTOMINAS, M. G. Characterisation and classification of Greek pine honeys according to their geographical origin based on volatiles, physicochemical parameters and chemometrics. Food Chemistry, v. 146, p. 548-557, 2014.

[68] KING, J. C.; SHAMES, D. M.; WOODHOUSE, L. Zinc homeostasis in humans. Journal of Nutrition, Bethesda, v. 130, n.5, p.1360-1366, 2000.

[69] KISSMANN, K. G.; GROTH, D. Plantas infestantes e nocivas. 2. Ed. São Paulo: BASF, . 2000. t. 3. 722p.

[70] KOSIOR, A., CELARY, W., OLEJNICZAK, P., FIJAL, J., KROL, W., SOLARZ, W., PLOKA, P. (2007).The decline of the bumble bees and cuckoo bees (Hymenoptera: Apidae: Bombini) of Western and Central Europe. Oryx.41, 79-88.

[71] LEE, J. D. Química inorgânica não tão concisa. Tradução da 5 a ed. inglesa. São Paulo, SP: Edgard Blücher Ltda, 1999.

[72] LEITE, Raíssa Vitória Vieira et al. O Despertar para as abelhas: educação ambiental e contexto Escolar. In: III CONEDU-Congresso Nacional de Educação. 2016.

[73] LIBERATO, M. C. T. C.; MORAIS, M. S. Produtos apícolas do Ceará e suas origens florais - características físicas, químicas e funcionais. 44p. 2016.

[74] LIMA, I. V.; PEDROZO, M. F. M. Ecotoxicologia do cobre e seus compostos. Salvador: Centro de Recursos Ambientais (CRA), 2001 128p. 2v. (Séries Caderno de Referências Ambientais). Disponível em: $<$ http//web.cena.usp.br/apostilas>. Acesso em: 05/04/2019.

[75] LINS, A.C.S.; SILVA, T.M.S.; CAMARA, C.A.; DÓREA, M.C. SANTOS, F.A.R.; SILVA, R.A. Estudo químico, análise palinológica e atividade antiradicalar do pólen apícola (Apis mellifera). In: REUNIÃO ANUAL DA SOCIEDADE BRASILEIRA DE QUÍMICA, 29., 2005.

[76] LOIOLA, M. I. B. et al. Flora da Paraíba, Brasil: Combretaceae. Acta Botânica Brasílica, v.23, n.2, p.330-342, 2009.

[77] LORENZI, H. Árvores Brasileiras - vol. 02. Instituto Plantarum, Nova Odessa. 1999. 384p.

[78] LORENZI, H. Plantas Daninhas do Brasil - terrestres, aquáticas, parasitas e tóxicas. 3ํㅡㄹ ed. 2000

[79] MAFRA, D.; COZZOLINO, S. M. F. Importância do Zinco na nutrição humana: recentes observações. Revista de Nutrição, Campinas, v.17, n.1, p.79-87, 2004.

[80] LUCAS, R. E.; DAVIS, J_F. Relationships between pH values of organic soils and availabilities of 12 plant nutrients. Soil Science, v. 92, n. 3, p. 177-182, 1961.

[81] MARCHINI, L. C., MORETI, A C. de C. C., OTSUK, I. P. Análise de Agrupamento, com Base na Composição FísicoQuímica, de Amostras de Méis produzidos por Apis Mellifera L. no Estado de São Paulo. Ciência e Tecnologia de Alimentos, v. 25, n. 1, p. 8-17, 2005.

[82] MARCHINI, L. C., SOUZA, B. de A. Composição físico-química, qualidade e diversidade dos méis brasileiros de abelhas africanizadas. In: Congresso Brasileiro de Apicultura, 2006, Aracaju,1, 4.

[83] MARCHINI, L. C.; MORETI, A. C. C. C.; OTSUK, I. P. Análise de agrupamento, com base na composição físicoquímica, de amostras de méis produzidos por Apis mellifera L. no Estado de São Paulo. Ciência e Tecnologia de Alimentos, v. 25, n. 1, p. 8-17, 2005.

[84] MARCHINI, L.C.; SODRÉ, G.S.; MORETI, A.C.C.C. 2004. Mel brasileiro: composição e normas. Ribeirão Preto: A. S. Pinto, $111 \mathrm{p}$.

[85] MARCHINI, LC; MORETI, ACCC; OTSUK, IP; Ciênc. Tecnol. Aliment. 2005 , $25,8$.

[86] MATOS, F. J. A. Plantas da medicina popular do Nordeste. Fortaleza: EUFC, 1999, 80p.

[87] MBIRI, A.; ONDITI, A.; OYARO, N.; MURAGO, E. Determination of essential and heavy metals in Kenyan honey by atomic absorption and emission spectroscopy. Journal of Agriculture, Science and Technology, Nairobi, v. 13, n. 1, p. 107-115, 2011.

[88] MCINNES, M. A dieta do mel: como emagrecer dormindo. Ed. Gente: São Paulo, 2006. 159 p.

[89] MENDES, T. M. F. F. Determinação de espécies metálicas em mel de abelhas por ICP OES. 2003. Tese (Doutorado) - Universidade Estadual de Campinas, Instituto de Química. Campinas, 2003.

[90] MÍDIO, A. F.; MARTINS, D. I. Toxicologia de Alimentos. São Paulo: Varela, 2000.

[91] MISHRA, R. K; MOHAMMAD, N; ROYCHOUDHURY, N. Soil pollution: Causes, effects and control. Van Sangyan, v. 3, n. 1, India, 2016. 
[92] MORON, D., GRZES, I. M., SKORKA, P., SZENTGYORGYI, H., LASKOWSKI, R., POTTS, S. G., WOYCIECHOWSKI, M. 2012.Abundance and diversity of wild bees along gradients of heavy metal pollution. Journal of Applied Ecology. 49, $118-125$.

[93] MORS, Walter B. et al. Medicinal plants of Brazil. Reference Publications, Inc, 2000.

[94] NEVES, L.C.; ALENCAR, S.M.; CARPES, S.T. Determinaçãi da atividade antioxidante e do teor de compostos fenólicos e flavonoides totais em amostras de pólen apícola de Apis mellifera. Brazilian Journal of Food Technolology, Campinas, v. 8, p. 107-110, 2009.

[95] OGA, S.; CAMARGO, M.M.A.; BATISTUZZO, J.A.O. Fundamentos de toxicologia. 3. Ed São Paulo: Atheneu, 2008. $690 \mathrm{p}$.

[96] ORSI, R. de. GIOVANI, C.; GAZZIOLA, F.; BARBATTINI, R.; FUNARI, S. R. C. Partículas radioativas no mel de ABELHAS (Apis mellifera L.). Boletim da Indústria Animal, N. Odessa,v. 61, n.1, p.57-62, 2004

[97] OWA, F. W. Water pollution: sources, effects, control and management. International Letters of Natural Sciences, n. 3. p. 1-6, 2014.

[98] PAIVA, Adriana A.; RONDÓ, Patrícia HC; GUERRA-SHINOHARA, Elvira M. Parâmetros para avaliação do estado nutricional de ferro. Revista de Saúde Pública, v. 34, p. 421-426, 2000.

[99] PAMPLONA, B. Determinação dos elementos químicos inorgânicos do mel de Apis mellifera. Ciência e Cultura, São Paulo. v. 41, n. 7, p. 618, 1989.

[100] PAREJA, L. et al. Detection of Pesticides in Active and Depopulated Beehives in Uruguay. International Journal of Environmental Research and Public Health, v. 8, p. 3844-3858, 2011.

[101] PARK, K.J.; ANTONIO, G.C. 2006. Análises de materiais biológicos. Campinas: Universidade Estadual de Campinas, Faculdade de Engenharia Agrícola, 2006. $21 \mathrm{f}$.

[102] PAULO, L.; ANTUNES, P.; CAMPOS, M. G.; ANJOS, O. Utilização do teor em metais pesados no pólen como marcador ambiental: estudo preliminar. In: CONGRESSO IBÉRICO DE APICULTURA, 2, Guadalajara,. p. 75-76, 2012.

[103] PEDROZO, Maria de Fátima Menezes, LIMA, Irene Videira. Ecotoxicologia do cobre e seus compostos. In: Cadernos de Referência Ambiental, 002. Salvador: CRA. 2001.

[104] PEREIRA, F. de M., LOPES, M. T. do R., CAMARGO, R. C. R. de, VILELA, S. L. de O., Sistema de Produção de Mel. Embrapa Meio-Norte. Jul/2003.

[105] PERUGINI, M.; MANERA, M.; GROTTA, L.; ABETE, M.C.; TARASCO, R.; AMORENA, M. Heavy metal (Hg, Cr, Cd and $\mathrm{Pb}$ ) contamination in urban áreas and wildlife reserves: honeybees as bioindicators. Biological Trace Element Research, San Diego, v. 140, p. 170-176, 2011.

[106] PHIPPS, E. Pollution Prevention Concepts and Principles. National Pollution Prevention Center for Higher Education, 1995.

[107] PIETROVSKI, E. F. et al. Topical anti-inflammatory activity of Eugenia brasiliensis Lam. (Myrtaceae) leaves. Journal of Pharmacy and Pharmacology, v.60, n.4, p.479-487, 2008.

[108] PINHO FILHO, R. Criação de Abelhas. 3ed. Cuiabá: SEBRAE/MT. 83p. 2007

[109] PIRES, R. M. C. Qualidade do mel de abelhas apis mellifera linnaeus, 1758 produzido no Piauí. Teresina, 2011. 94f. Dissertação (Mestrado em Alimentos e Nutrição). Programa de Pós-Graduação em alimentos em nutrição, Universidade Federal do Piauí, Teresina- PI, 2011.

[110] POHL, P. 2009. Determination of metal content in honey by atomic absorption and emission spectrometries. Trends in Analytical Chemistry, 28 (1)

[111] PONTES, M., MARQUES; J. \& CAMARA, J. (2007) - Screening of volatile composition from Portuguese multifloral honeys using headspace solid-phase microextraction-gas chromatography-quadrupole mass spectrometry. Talanta 74, 1: 91-103.

[112] PORRINI, C.; SABATINI, A. G.; GIROTTI, S.; GHINI, S.; MEDRZYCKI, P.; GRILLENZONI, F.; BORTOLOTTI, L.; GATTAVECCHIA, E. and CELLI, G. 2003. Honey bees and bee products as monitors of the environmental contamination.Apiacta, 38, 63-70.

[113] PRATES, Helena Magalhães et al. Teores elevados de manganês em amostras de solos. Fórum Ambiental da Alta Paulista, p. 1563-1574, 2011.

[114] RACOWSKI, I.; SILVAS, F. P. C.; TAKUSHI, D. T. T.; SILVA, D. W. G. da; MIRANDA, P. dos S. Ação antimicrobiana do mel em leite fermentado.Analytica, São Paulo, n. 30, p. 106-115, 2007.

[115] RAJESWARI, T. R.; SAILAJA, N. Impact of heavy metals on environmental pollution. National Seminar on Impact of Toxic Metals, Minerals and Solvents leading to Environmental Pollution. Journal of Chemical and Pharmaceutical Sciences, p. 175- 181, 2014. 
[116] RAMOS, M. J.; CARVALHO, C. N. Estudo morfológico e biológico das fases de desenvolvimento de Apis mellifera. Revista Científica eletrônica de Engenharia Florestal, 2007.

[117] ROCCA, A. C. C. (2004). Fontes de Poluição de Solos e Aguas Subterrâneas. In: Prevenção e Controle da Poluição do Solo e das Águas Subterrâneas. São Paulo: CETESB. Apostila.

[118] RODRIGUES, A. E. et al. Análise físico-química dos méis das abelhas Apis Mellifera e Melípona Scutellaris produzidos em regiões distintas no Estado da Paraíba. Ciência Rural, Universidade Federal de Santa Maria, Santa Maria, v. 35, n005, p. 1166-1171, 2005.

[119] RODRIGUES, A. S.; ÁVILA, S. G. Caracterização Físico-Química da Casca de Ovo de Galinha e Utilização como Fonte para Produção Compostos de Cálcio. Revista virtual de química, v. 9, n. 4, p. 596-607, 2017.

[120] ROSA, Paulo Castro Cardoso da et al. Risco de contaminação ambiental em área de mineração de cobre e estudo toxicológico em Drosophila melanogaster. 2018.

[121] ROSA, R da S.; MESSIAS, R. A.; AMBROZINI, B. Importância da compreensão dos ciclos biogeoquímicos para o desenvolvimento sustentável. Instituto de Química de São Carlos - USP. São Carlos, 2003.

[122] SAMPAIO, J. A., ANDRADE, M. C. D., DUTRA, A. J. B., \& PENNA, M. T. M. (2008). Manganês. CETEM/MCTI.

[123] SANTOS, D. da C.; MOURA NETO, L. G.; MARTINS, J. N.; SILVA, K. F. N. L. Avaliação da qualidade físico-química de amostras de méis comercializadas na Região do Vale do Jaguaribe - CE. Revista Verde de Agroecologia e Desenvolvimento Sustentável, Mossoró, v. 4, n. 4, p. 21-26, 2009.

[124] SAULOVIĆ, D; BIOČANIN, R; RODRIGUEZ, B. Bioindicators in human environment. Faculty of Biology, University of Belgrade. Serbia, 2001.

[125] SENAR. Abelhas Apis mellifera: instalação do apiário/Serviço Nacional de Aprendizagem Rural. 2. ed. Brasília: SENAR, 2010.

[126] SENGIK, E. S. Os macronutrientes e os micronutrientes das plantas. 2003. Disponível em $<$ www.nupel.uem.br/nutrientes-2003.pdf>Acesso em 18/04/2019.

[127] SHILS, M. E.; OLSON, J. A.; SHIKE, M.; ROSS, A. C. Tratado de nutrição moderna na saúde e na doença. 9 ed. São Paulo: Manole, 2003.

[128] SINGER, E; SCHWALD, D. Ecology: A study guide. Teacher's manual. Germany: Leybold Didatic GmbH. Federal Republik of Germany, 1991.

[129] SIRVINSKAS, Luiz Paulo. Manual de direito ambiental. Editora Saraiva, 2018.

[130] SLESSOR, K. N.; WINSTON, M. L.; LE CONTE, Y. Pheromone communication in the honeybee (Apis mellifera L.). Journal of Chemical Ecology, v. 31, n. 11, p. 2731-2745, 2005.

[131] SODRÉ, G. S.; MARCHINI, L. C.; ZUCCHI, O. L. A. D.; NASCIMENTO FILHO, V. F.; OTSUK, I. P.; MORETI, A. C. C. C. Determination of chemical elements in africanized Apis mellifera (Hymenoptera: Apidae) honey samples from the State of Piauí, Brazil. Química Nova, v. 30, n. 4, p. 920-924, 2007.

[132] SORVARI, J., RANTALA, L. M., RANTALA, M. J., HAKKARAINEN, H., EEVA, T. (2007). Heavy metal pollution disturbs immune response in wild ant populations. Environmental Pollution. 145, 324-328.

[133] SOUSA, B. A.; CARVALHO, C. A.L.; ALVEZ, R. M. O.; DIAS, C.; CLARTON, L. Munduri (Melipona asilvai): a abelha sestrosa. Cruz das Almas: Nova civilização, 2009. 46 p.

[134] SOUSA, J. R. L. JUNIOR, O. P de A.; BRITO, N. M.; FRANCO, T. C. R dos S. Ação de pesticidas sobre abelhas: avaliação do risco de contaminação de méis. Actatenológica, v. 1, p. 28-36, 2013.

[135] SOUSA, M. P.; MATOS, M. E. O.; MATOS, F. J. A.; MACHADO, M. I. L.; CRAVEIRO, A. A. Constituintes químicos ativos e propriedades biológicas de plantas medicinais brasileiras. Fortaleza: Editora UFC, 2009, 448 p.

[136] STANKOVSKA, E.; STAFILOV, T.; SAJN, R. Monitoring of trace elements in honey from the Republic of Macedonia by atomic absorption spectrometry. Environmental Monitoring and Assessment, Dordrecht, v. 142, n. 1/3, p. 117-126, 2008.

[137] STRAMM, Klaus Martin. Composição e qualidade de méis de abelha jandaíra (Melipona subnitida), efeitos de estocagem e comparação com méis de Apis mellifera. Dissertação.Faculdade de Ciências Farmacêuticas da Universidade de São Paulo. Departamento de Alimentos e Nutrição Experimental. Programa de pós-graduação em Ciência dos Alimentos:área de bromatologia). São Paulo. 2011.

[138] SUGIMOTO, Jun et al. Magnesium decreases inflammatory cytokine production:a novel innate immunomodulatory mechanism. The Journal of Immunology, v.188, n.12, p.6338-6346, 2012.

[139] SUMITA, N.M.; MENDES, M.E.; MACCHIONE, M.; GUIMARÃES, E.T.; LICHTENFELS, A,J.F.C.; LOBO, D.J.A.; SALDIVA, P.H.N. Tradescantia pallida cv. purpurea Boom in the characterization o fair pollution by accumulation of tTrace elements. Journal of the Air \& Waste Management Association, v. 53, p.574-579, 2003. 
[140] SZCZESNA, T. (2007).Concentration of selected elements in honeybee-collected pollen. Journal of Apicultural Science. 51, 5-13.

[141] THOMANZINI, M.J.; THOMANZINI, A.P.B.W. Levantamento de insetos e análise entomofaunística em floresta, capoeira e pastagem no Sudeste Acreano. Boletim de Pesquisa e Desenvolvimento, Rio Branco, v. 1, n.35, p. 10-41, 2002.

[142] TISDALE, S. L.; NELSON, W. L.; BEATON, J. D.; HAVLIN, J. L. Soil fertility and fertilizers. 5. ed. New York: MacMillan, 1993.

[143] TORREnZA, M. A. Minerais Essenciais em Méis. 2008. 85 f. Dissetação paraMestrado. Área de Ciência de Alimentos. Universidade Estadual de Campinas. 2008

[144] TUZEN, M.; SILICI, S.; MENDIL, D.; SOYLAK, M. Trace element levels in honeys from different regions of Turkey. Food Chemistry, Amsterdam, v. 103, p. 325-330, 2007.

[145] ULUOZLU, O.D.; TUZEN, M,. MENDIL, D.; SOYLAK, M. Trace metal contente in nine species of fish from the Black and Aegean Seas, Turkey. Food Chemistry, London, v. 104, n.2, p. 835-840, 2007.

[146] ÜREN, A.; SERIFOGLU, A.; SARIKAHYA, Y. Distribution of elements in honey and effect of thermoelectric power plant on the element contents. Food Chemistry, v. 61, n. 1/2, p. 185-190, 1998.

[147] VAN Dyk,, G.M. Pieterse and J.H.J. Van Vuren. 2005. Histological changes in the liver of Oreochromis mossambicus (Cichlidae) after exposure to cadmium and zinc. Ecotoxicology and Environmental Safety Article in Press, Corrected Proof - Note to users J.C.

[148] VAN ELDIK, R. (1999) Mechanistic studies in coordination chemistry. Coordenation Chemistry Reviews.182 (1), 373-410.

[149] VANHANEN, L. P.; EMMERTZ, A.; SAVAGE, G. P. Mineral analysis of mono-floral New Zealand honey. Food Chemistry, Amsterdam, v. 128, p. 236-240, 2011.

[150] VENTURIERI, G. C. Criação de abelhas indígenas sem ferrão. 2. Ed. Belém, PA: Embrapa Amazônia Oriental, 2008. $60 \mathrm{p}$.

[151] VIDAL, M. G.; SANTANA, N. S.; VIDAL, D. Flora apícola e manejo de apiários na Região do Recôncavo Sul da Bahia. Revista Acadêmica Ciência Agrária Ambiental, v. 6; n. 4; p. 503 - 509, 2008.

[152] WHITE, J. W. Physical characteristics of honey. In: CRANE, E. Honey a comprehensive survey. London: Heinemann, p. 207-239, 1975.

[153] WINSTON, M. L.; The Biology of the Honey Bee, Harvard University Press: Cambridge, Mass., 1987.

[154] WOLF, F.I.; TRAPANI, V. Cell (patho) physiology of magnesium. Clin Sci. V.114, n.1, p.27-35. 2008.

[155] WOLF, L.F.; REIS, V.D.A. dos; SANTOS, R.S.S dos Abelhas melíferas; bioindicadores de qualidade ambiental e de sustentabilidade da agricultura familiar de base ecológica. Pelotas: Embrapa Clima Temperado, 2008, 38 p.

[156] ZEBARTH, BJ et al. Influência de alterações de resíduos orgânicos em propriedades físicas e químicas selecionadas do solo. Canadian Journal of Soil Science, v. 79, n. 3, p. 501-504, 1999. 


\section{Capítulo 2}

Análises físico-químicas de méis das floras angico e silvestre dos estados de Minas Gerais e Rio Grande do Sul

Amanda Batista Nascimento

Maria da Conceição Tavares Cavalcanti Liberato

Kamila de Lima Barbosa

Kananda Lara Santos Sales

Renata Almeida Farias

Kessia Oliveira Targino

Erica Carneiro de Sousa

Resumo: 0 mel é considerado um fluido viscoso, aromático e doce elaborado por abelhas a partir do néctar e/ou exsudatos sacarínicos de plantas, principalmente de origens florais. Analisadas as amostras dos méis das floradas Angico e Silvestre dos estados de Minas Gerais e Rio Grande do Sul, com o objetivo de contribuir para o conhecimento das características físico-químicas desse produto. Os parâmetros analisados foram: Umidade, pH, Determinação do índice de refração e Determinação de presença de corantes. Os testes foram feitos no Laboratório de Bioquímica e Biotecnologia (Labbiotec) da Universidade Estadual do Ceará. 0 resultado obtido para a Umidade do mel de Minas Gerais apresentou 20,6\% e o de Caxias do Sul 20,4\%. Já o resultado para sólidos solúveis totais na escala ${ }^{\circ}$ Brix foram 77,8\% e 78\%, pH de 4,02 e 4,09 para os méis acima citados, respectivamente. Quanto ao teste de corante não houve mudança de coloração em ambos.

Palavras chaves: Mel; Adulteração; Propriedades Físico-Químicas. 


\section{INTRODUÇÃO}

O mel é basicamente composto por frutose e glicose, dois tipos de açúcares simples, e outras substâncias como minerais, proteínas, ácidos orgânicos, vitaminas, hormônios, enzimas e pigmentos vegetais. Sua composição nutricional depende de muitos fatores como: origem do néctar, a espécie de abelha que o produziu, tipo da flor, solo e condições climáticas. 0 mel pode ser consumido no seu estado liquido ou cristalizado. Essa passagem de estado, é um processo natural, ele não sofre nenhuma alteração. 0 progressivo aumento da exportação de mel, com preços e qualidade inferiores, conduziu à necessidade de se adotarem técnicas que permitissem avaliar a autenticidade do mesmo (PIRES et al., 2009). A principal forma de falsificação do mel é pela adição de açúcar comercial, glucose e dextrinas. Além disso, pode ocorrer no comércio mel artificial, que é constituído por açúcar com adição de substâncias aromáticas e/ou de mel natural.

O mel é conhecido por ser rico em antioxidantes enzimáticos e não-enzimáticos, incluindo glucose oxidase, catalase, ácido ascórbico, flavonoides, ácidos fenólicos, derivados de carotenoides, ácidos orgânicos, produtos da reação de Maillard, aminoácidos e proteínas. (MAGALHÃES, 2010).

Os danos causados pelos radicais livres podem afetar muitas moléculas biológicas, dentre elas os lipídeos, as proteínas, os carboidratos e as vitaminas presentes nos alimentos. Estudos apontam que uma dieta rica em antioxidantes reduz os riscos das principais doenças humanas, entre elas as cardiovasculares e o câncer.

No Brasil, o controle de qualidade de méis está mais destinado a análises físico-químicas e microbiológicas, mas diversos laboratórios realizam hoje em dia análises polínicas de méis. Os conhecimentos de melissopalinologia têm sido usados no Brasil para qualificação de produtos apícolas por cooperativas e associações de apicultores em vários estados, sendo, todavia, desejável uma inspeção técnico-científica mais rigorosa (BARTH, 2004).

Sendo o mel um produto natural, tradicionalmente utilizado na alimentação, a avaliação da sua capacidade associada a esse fator poderá apresentar um papel relevante e conduzir a uma valorização do produto junto do consumidor.

\section{MATERIAL E MÉTODOS}

\subsection{MATERIAIS}

Tabela 1- Relação dos méis analisados

\begin{tabular}{|c|c|c|}
\hline Amostra & Florada & Local de coleta \\
\hline Mel 1 & Angico & Minas Gerais \\
\hline Mel 2 & Silvestre & Caxias do Sul \\
\hline
\end{tabular}

\subsection{METODOLOGIAS}

\subsubsection{TESTE DE UMIDADE}

A umidade das amostras foi determinada através de um refratômetro manual (MOD. 2 WAJ BIOBRIX), através da medida do ângulo de desvio, de um raio de luz que incide em uma solução de açúcares (sólidos solúveis), podendo-se medir a concentração desta solução que será proporcional ao desvio. Os refratômetros para essa finalidade possuem uma escala em graus Brix (g de sólidos/ 100g solução) paralelamente à escala de índice de refração. Conhecendo a concentração de sólidos solúveis calculamos o valor de umidade.

\subsubsection{SÓLIDOS SOLÚVEIS TOTAIS ( $\left.{ }^{\circ} B R I X\right)$}

A escala Brix é calibrada pelo número de gramas de açúcar contidos em 100g de solução. Quando se mede o índice de refração de uma solução de açúcar, a leitura em percentagem de Brix deve combinar com a concentração real de açúcar na solução. A analise foi feita utilizando-se um refratômetro manual (MOD. 2 WAJ BIOBRIX), em escala de 0 a 30\%. Colocou-se aproximadamente uma gota de água destilada no local 
para análise, por seguinte limpou-se com algodão e colocou-se uma gota do mel para análise. A água destilada foi usada para calibrar o refratômetro.

\subsubsection{DETERMINAÇÃO DO pH}

Pesou-se $10 \mathrm{~g}$ da amostra em béquer de $250 \mathrm{~mL}$, adicionou-se $100 \mathrm{~mL}$ de água, recentemente fervida e fria, para medir o pH, imediatamente após a calibração do equipamento. Sempre mantendo o bulbo do eletrodo dentro da amostra que está se realizando a medida quando se está determinando o pH. Desligouse da tensão, lavaram-se os eletrodos com água destilada e imergiu-se na solução de descanso ( $\mathrm{KCl} 3 \%)$.

\subsubsection{DETERMINAÇÃO DE CORANTES}

Pesou-se $1 \mathrm{~g}$ de mel e dissolveu-se em $10 \mathrm{ml}$ de água destilada; depois adicionou-se cerca de $2 \mathrm{ml}$ de solução de ácido sulfúrico a 5\%. 0 mel deve permanecer com a coloração inalterada. Se existem substâncias corantes adicionadas ao mel, a cor passa gradualmente de violeta a rosa.

\section{RESULTADOS E DISCUSSÕES}

\subsection{TESTE DE UMIDADE}

Tabela 2- Teor de umidade em méis de Minas Gerais e Rio Grande do Sul, respectivamente.

\begin{tabular}{|c|c|}
\hline Amostra & Teor \% \\
\hline Mel 1 & 20,6 \\
\hline Mel 2 & 20,4 \\
\hline
\end{tabular}

$\mathrm{O}$ teor de umidade pode afetar enormemente a qualidade dos méis, consequentemente, o seu prazo de validade. Alguns autores estimam que um mel com umidade superior a 21\% fermenta em 3 ou 4 meses. A instrução normativa número 11 de 2000, através do seu Regulamento Técnico de Identidade e Qualidade do Mel (BRASIL, 2000) define o limite máximo de 20\%, sendo que o ideal é um teor de 17 a 18\%. Os méis analisados neste trabalho possuem os seguintes valores: Mel 1 (florada Angico de Minas Gerais) teor = 20,6\%; mel 2(florada Silvestre de Rio Grande do Sul) teor $=20,4 \%$, mostrando que estão dentro dos parâmetros estimados pela Legislação brasileira.

\subsection{SÓLIDOS SOLÚVEIS TOTAIS}

As escalas em percentagem de Brix apresentam as concentrações percentuais dos sólidos solúveis contidos em uma amostra. Os sólidos solúveis contidos é o total de todos os sólidos dissolvidos na água, começando com açúcar, sais, proteínas, ácidos, etc. A leitura do valor medido é a soma total desses (MORAES, 2006). Os valores do ${ }^{\circ}$ Brix para o mel de florada Angico foi $77,8 \%$ e o ${ }^{\circ}$ Brix para o mel de florada Silvestre foi $78 \%$. De acordo com a literatura os valores obtidos estão dentro dos padrões estabelecidos.

Tabela 3- Sólidos solúveis totais em méis de Minas Gerais e Rio Grande do Sul, respectivamente.

\begin{tabular}{|c|c|}
\hline Amostra & Brix \% \\
\hline Mel 1 & 77,8 \\
\hline Mel 2 & 78,0 \\
\hline
\end{tabular}

\subsection{DETERMINAÇÕES DE pH}

$\mathrm{O}$ valor de $\mathrm{pH}$ do mel pode ser influenciado pelo $\mathrm{pH}$ do néctar, solo ou associação de vegetais para composição do mel. Substâncias mandibulares da abelha acrescidas ao néctar quando do transporte até a colmeia também podem alterar o pH do mel. De acordo com a Legislação brasileira o pH do mel deve variar entre 3,3 e 4,6. Os resultados obtidos foram de mel 1 (florada Angico de Minas Gerais) pH= 4,02; mel 2 (florada Silvestre de Rio Grande do Sul) pH= 4,09. Concluímos que os méis estão dentro dos parâmetros estabelecidos pela Legislação brasileira (BRASIL, 2000). 
Tabela 4- Determinação do pH de méis de Minas Gerais e Rio Grande do Sul, respectivamente.

\begin{tabular}{|c|c|}
\hline Amostra & $\mathrm{pH}$ \\
\hline Mel 1 & 4,02 \\
\hline Mel 2 & 4,09 \\
\hline
\end{tabular}

\subsection{DETERMINAÇÕES DE CORANTES}

Não ocorreu nenhuma mudança de colocação nas duas amostras de mel, mostrando que o mel 1 (florada Angico de Minas Gerais) e o mel 2 (florada Silvestre de Rio Grande do Sul) estão dentro dos parâmetros do Padrão de Identidade e Qualidade do Mel. Esse teste indica a presença de substâncias corantes, sejam elas naturais ou artificiais, presentes no mel. Em mel puro a cor permanece âmbar, já em mel adulterado a cor passa gradualmente do violeta à rosa.

\section{CONCLUSÕES}

É de fundamental importância a caracterização de méis, visando a criação de padrões segundo os fatores edafoclimáticos e florísticos das regiões das quais se fazem as colheitas deles ,estabelecendo-se critérios de avaliação para o mel, para evitar possíveis fraudes com açúcar comercial, glicose e outros componentes que podem interferir nos constituintes do mel, obtendo-se um meio que se pode garantir a certeza de que o produto oferecido na região atende as necessidades de qualidade exigidas pelos consumidores.

Mediante as análises e os valores obtidos, concluímos que os méis de florada Angico proveniente de Minas Gerais e o mel de florada Silvestre proveniente do Rio Grande do Sul, apresentaram valores que correspondem a méis livres de adulterações. As amostras de méis analisadas estão de acordo com a Legislação Brasileira para o consumo.

\section{REFERÊNCIAS}

[1] ADOLFO LUTZ. Métodos físico-químicos para análise de alimentos. 4o ed. Brasília: ANVISA, 2005.

[2] BARTH, O. M. Melissopalynology in Brazil: a review of pollen analysis of honeys, propolis and pollen loads of bees. Scientia Agricola, n. 61, v. 3, p. 342-350, 2004.

[3] BRASIL, Ministério da Agricultura, Pecuária e Abastecimento, Instrução Normativa 11, de 20 de outubro de 2000, Regulamento técnico de identidade e qualidade do mel. Disponível em:http://www.agricultura.gov.br/das/dipoa/anexo_intrnorm11. htm. Acesso em: 02 de maio de 2020.

[4] BRASIL. Instrução Normativa n. 11, de 20 de outubro de 2000. Regulamento Técnico de Identidade e Qualidade de Mel. Diário Oficial da União, Brasília, DF, 23 out 2000. Seção 1, n. 204, 23 p.

[5] CRANE, E. O livro do mel. 2ª edição. São Paulo: Nobel, 1985. 226 p.

[6] EVANGEliSTA-RodRigueS, A.; SILVA, E. M. S. da; BEZERRA, E. M. F. Análises físico-químicas de méis de abelhas Apis mellifera e Melipona scutellaris. Disponível em: http//www.agroline.com.br/agrociencia/pdf. Acesso: 02 de junho de 2020.

[7] MAGALHÃES, I. L. Fenóis totais e propriedades biológicas de méis de diferentes localidades geográficas. (51ํำ CBQ - 2010)

[8] MORAES, R. R. Refratometria. Disponível em:<http://www.fapepi.pi.gov.br/cien cia/documentos/REFRAT\%D4METRO.PDF>. Acesso: 01 junho 2020.

[9] PIRES, J, ESTEVINHO, M. L., FEÁS, X., CANTALAPIEDRA, J. E IGLESIAS, A. Pollen spectrum and physicochemical attributes of heather (Erica sp.) honeys of north Portugal. Journal of the Science of Food and Agriculture, n. 89, p. 1862-1870, 2009.

[10] RIBEIRO, E. P.; SERAVALLI, E. A. G. Química de Alimentos. 1aㅡ Ed. São Paulo: Edgard Blücher. 2004.

[11] PEREIRA, F. M. et al. Produção de Mel. Embrapa. Jul. 2003. 


\section{Capítulo 3}

Parâmetros físicos e químicos na caracterização de pães elaborados com casca de pitaya como substituto parcial de farinha integral

Nathália Maioli Crema

Gabrielly Ribeiro Carneiro

Leomara Floriano Ribeiro

Resumo: As sementes e as cascas de pitaya podem ser reaproveitadas no desenvolvimento de novos produtos. Neste contexto, o objetivo deste estudo foi desenvolver pães integrais acrescidos de farinha de casca de pitaya (FCP) e sementes (SMP) em diferentes proporções. As amostras foram secas e posteriormente moídas. Os pães foram elaborados adicionando de 0 a $25 \%$ de FCP e de 0 a $70 \mathrm{~g}$ de SMP. A caracterização da SP, da FCP e dos pães foi realizada por meio das análises de determinação de umidade e de conteúdo mineral por gravimetria, teor de proteínas pelo método de micro Kjeldahl, teor de lipídeos por Goldfish, determinação de glicídios totais pelo método de Lane-Eynon, acidez aquo-solúvel por titulometria e a capacidade antioxidante em espectrofotometria UV/Vis. A SMP e a FCP apresentaram teores significativos de proteína $(20,24 \pm 1,15$ e 8,23 $\pm 4,31$ g 100g-1), respectivamente. A FCP apresentou capacidade antioxidante pelo teor de compostos fenólicos totais $(947,62 \pm$ 29,43 mg EAG 100g-1), métodos $\beta$-caroteno/ácido linoleico (81\%) e ABTS (255,26 \pm 93,21 $\mu \mathrm{M}$ trolox g-1), tornando viável sua aplicação no desenvolvimento de pães. Além disso a adição de FCP e SMP influenciaram na composição dos pães, sendo que a formulação com 25\% de FCP e $30 \mathrm{~g}$ de semente de pitaya (F4) foi significativamente diferente das demais $(\mathrm{p} \leq 0,05)$ em relação as características físicas e químicas. Conclui-se que a adição da farinha da casca e semente de pitaya podem contribuir nas características nutricionais aos pães, porém são necessários mais estudos.

Palavras-chave: compostos bioativos, panificação, Hylocereus costaricensis, capacidade antioxidante, novos produtos. 


\section{INTRODUÇÃO}

A pitaya, é uma fruta pertencente à família Cactacea, vista como um alimento que possui um valor nutricional considerável e qualidade em termos de sabor e aparência. No entanto, a indústria assim como o consumidor desta fruta in natura faz uso apenas da polpa, tornando as demais frações, como casca e semente, resíduos que podem também ser fontes de nutrientes e antioxidantes e serem utilizados em produtos alimentícios (FERNANDES et al., 2018). Diante do exposto, a fim de minimizar os impactos ambientais causados pelos resíduos e avaliar a viabilidade de reaproveitá-los em indústrias de alimentos, o objetivo deste estudo foi desenvolver pães integrais acrescidos de farinha de casca de pitaya e sementes em diferentes proporções e avaliá-los física e quimicamente.

\section{MATERIAIS E MÉTODOS}

As pitayas (Hylocereus costaricensis) foram higienizadas e as frações de casca e semente (SMP) foram separadas e secas. As cascas foram moídas para obtenção da farinha de casca de pitaya (FCP). Em seguida, procedeu-se a elaboração manual dos pães sem repetição, em que na formulação padrão (F1) de pão integral foram acrescentados 10, 15 e $25 \%$ de FCP, em substituição parcial da farinha de trigo integral, e adicionados 30, 50 e $70 \mathrm{~g}$ de SMP, de maneira a se obter as formulações F2, F3 e F4, como mostra a Tabela 1.

Tabela 1 - Formulações de pães integrais com adição de farinha de casca e de semente de pitaya:

\begin{tabular}{|l|c|c|c|c|}
\hline \multicolumn{1}{|c|}{ Ingredientes } & F1 (0\%) & F2 (10\%) & F3 (15\%) & F4 (25\%) \\
\hline Farinha de trigo integral (g) & 300 & 270 & 255 & 225 \\
\hline Farinha de casca de pitaya (g) & 0 & 30 & 45 & 75 \\
\hline Semente de pitaya (g) & 0 & 70 & 50 & 30 \\
\hline Açúcar mascavo (g) & 20 & 20 & 20 & 20 \\
\hline Óleo de Coco (g) & 10 & 10 & 10 & 10 \\
\hline Fermento biológico (g) & 15 & 15 & 15 & 15 \\
\hline Sal (g) & 3 & 3 & 3 & 3 \\
\hline Ovo (unidade) & 2 & 2 & 2 & 2 \\
\hline Água (mL) & 150 & 150 & 150 & 150 \\
\hline
\end{tabular}

Tanto a FCP, a SMP e os pães foram caracterizados física e químicamente, por meio das análises de determinação de umidade e de conteúdo mineral por gravimetria, teor de proteínas pelo método de micro Kjeldahl, teor de lipídeos por Goldfish, determinação de glicídios totais pelo método de Lane-Eynon, acidez aquo-solúvel por titulometria, fibra bruta pelo método detergente (IAL, 2008). Avaliou-se também o teor de compostos fenólicos totais (SINGLETON; ROSSI, 1965) e a atividade antioxidante, pelos métodos de captura do radical ABTS (RUFINO et al., 2007) e sistema de auto-oxidação $\beta$-caroteno/ácido linoleico (RUFINO et al., 2006), onde foram realizadas por método espectrofotométrico UV/Vis. Todas as análises foram realizadas em triplicata, avaliadas pela análise de variância (ANOVA) e Teste de Tukey.

\section{RESULTADOS E DISCUSSÃO}

Os resultados de caracterização física e química estão na Tabela 2, sendo possível observar que a SMP pode ser considerada uma fonte proteica, enquanto que FCP tem valores consideráveis de compostos fenólicos totais e atividade antioxidante pelos métodos ABTS e $\beta$-caroteno/ácido linoleico. 
Tabela 2 - Caracterização física e química da semente de pitaya (SMP) e farinha de casca de pitaya (FCP):

\begin{tabular}{|l|c|c|}
\multicolumn{1}{|c|}{ Análises } & Semente (SMP) & Farinha (FCP) \\
\hline Umidade $\left(\mathrm{g} 100 \mathrm{~g}^{-1}\right)$ & $64,58 \pm 0,56$ & $4,74 \pm 0,08$ \\
\hline Conteúdo mineral $\left(\mathrm{g} 100 \mathrm{~g}^{-1}\right)$ & $3,06 \pm 0,04$ & $13,85 \pm 0,05$ \\
\hline Proteína $\left(\mathrm{g} 100 \mathrm{~g}^{-1}\right)$ & $20,24 \pm 1,15$ & $8,23 \pm 4,31$ \\
\hline Lipídeos $\left(\mathrm{g} 100 \mathrm{~g}^{-1}\right)$ & $4,79 \pm 0,75$ & $4,22 \pm 2,78$ \\
\hline Glicídios totais $\left(\mathrm{g} 100 \mathrm{~g}^{-1}\right)$ & - & $34,32 \pm 1,93$ \\
\hline Acidez $\left(\mathrm{g}\right.$ ácido cítrico $\left.100 \mathrm{~g}^{-1}\right)$ & $0,20 \pm 0,02$ & $3,74 \pm 0,21$ \\
\hline Compostos fenólicos $\left(\mathrm{mg}\right.$ EAG $\left.100 \mathrm{~g}^{-1}\right)$ & $50,72 \pm 9,04$ & $947,62 \pm 29,43$ \\
\hline ABTS $(\mu$ Mtrolox g-1) & - & $255,26 \pm 93,21$ \\
\hline$\beta$-caroteno/ácido linoleico $(\%)$ & - & $81,18 \pm 2,03$ \\
\hline
\end{tabular}

*Resultados expressos em base seca como média \pm desvio padrão (n=3). (-): resultados não significativos.

Os parâmetros físicos e químicos das formulações dos pães estão na Tabela 3. Os resultados indicaram que a formulação F4 com 25\% de FCP e 30 g de SMP apresentou resultados significativamente $(p \leq 0,05)$ diferentes e superiores as demais formulações em todas as análises.

Tabela 3 - Caracterização física e química dos pães integrais com semente de pitaya (SMP) e farinha de casca de pitaya (FCP):

\begin{tabular}{|c|c|c|c|c|}
\hline Análises & F1 & F2 & F3 & F4 \\
\hline Umidade (g $100 \mathrm{~g}^{-1}$ ) & $41,74^{\mathrm{d}} \pm 1,29$ & $45,23^{c} \pm 1,67$ & $49,27 b \pm 1,13$ & $57,50^{a} \pm 0,15$ \\
\hline Conteúdo mineral (g $\left.100 \mathrm{~g}^{-1}\right)$ & $2,13^{\mathrm{d}} \pm 0,03$ & $3,18^{\mathrm{c}} \pm 0,04$ & $3,64^{\mathrm{b}} \pm 0,04$ & $4,87 \mathrm{a} \pm 0,04$ \\
\hline Proteína (g 100 g-1) & $14,55^{a} \pm 0,81$ & $18,67 a \pm 3,32$ & $15,50 \mathrm{a} \pm 0,88$ & $17,75^{a} \pm 1,83$ \\
\hline Lipídeos (g $100 \mathrm{~g}^{-1}$ ) & $5,33^{\mathrm{ab}} \pm 0,12$ & $3,78^{\mathrm{b}} \pm 0,18$ & $5,17 \mathrm{ab} \pm 2,22$ & $8,73^{a} \pm 1,83$ \\
\hline Glicídios totais (g em $100 \mathrm{~g}$ ) & $15,16^{\mathrm{a}} \pm 1,85$ & $16,27 \mathrm{a} \pm 3,96$ & $16,74^{a} \pm 1,56$ & $19,32^{\mathrm{a}} \pm 0,80$ \\
\hline $\begin{array}{l}\text { Acidez aquo-solúvel } \\
\left(\mathrm{mg} \mathrm{NaOH} 100 \mathrm{~g}^{-1}\right)\end{array}$ & $45,15^{c} \pm 0,29$ & $102,82^{b} \pm 0,25$ & $90,80^{\mathrm{ab}} \pm 0,35$ & $167,22^{\mathrm{a}} \pm 1,11$ \\
\hline $\begin{array}{l}\text { Compostos fenólicos } \\
\text { (mg EAG } 100 \mathrm{~g}^{-1} \text { ) }\end{array}$ & $114,92^{\mathrm{c}} \pm 10,89$ & $240,83^{b} \pm 6,95$ & $239,36^{b} \pm 11,33$ & $341,94^{\mathrm{a}} \pm 14,78$ \\
\hline
\end{tabular}

F1: controle 0\% de FCP e SMP; F2: 10\% de FCP e $70 \mathrm{~g}$ de SMP; F3: 15\% de FCP e $50 \mathrm{~g}$ de SMP; F4: 25\% de FCP e $30 \mathrm{~g}$ de SMP. Resultados expressos como média \pm desvio padrão $(n=3)$. Médias seguidas por letras diferentes na mesma linha indicam diferença significativa pelo teste de Tukey $(p \leq 0,05)$.

Por meio dos resultados da Tabela 3 e conforme pode ser visualizado na Figura 1, percebeu-se que o acréscimo da farinha da casca de pitaya e da semente de pitaya podem ser usadas como substitutos parciais no desenvolvimento de novos produtos, em específico de pães.

Figura 1 - Formulações de pães integrais com semente de pitaya (SMP) e farinha de casca de pitaya (FCP).

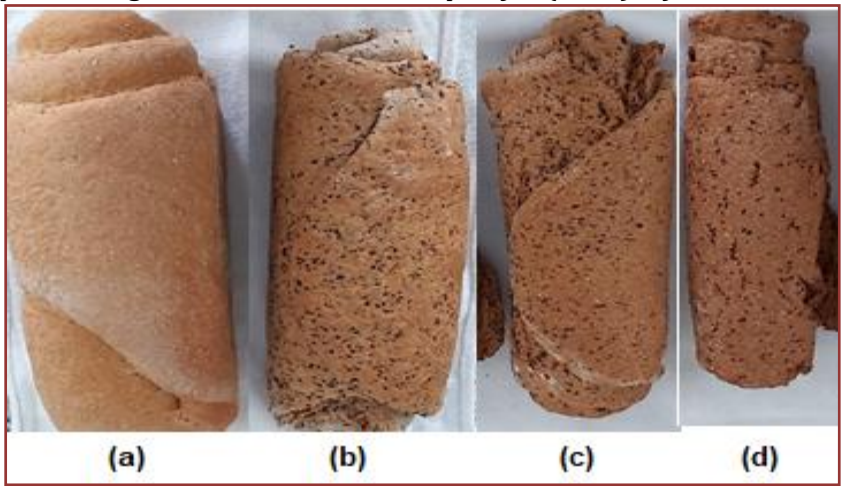

Nota: (a) 0\% de FCP e SMP; (b) 10\% de FCP e 70 g de SMP; (c) 15\% de FCP e $50 \mathrm{~g}$ de SMP; (d) 25\% de FCP e $30 \mathrm{~g}$ de SMP 


\section{CONCLUSÃO}

Conclui-se que foi possível desenvolver pães com substituição parcial de farinha de trigo integral, visto que as características físicas e químicas da farinha da casca de pitaya e da semente de pitaya usadas como substitutos influenciaram positivamente na composição dos pães.

\section{AGRADECIMENTOS}

Agradecimentos à UFPR e a Fundação Araucária pelo apoio financeiro.

\section{REFERÊNCIAS}

[1] FERNANDES, D.R., MOREIRA, R.A., CRUZ, M.M., RABELO, J.M., OLIVEIRA, J. Improvement of production and fruit quality of pitayas with potassium fertilization. Acta Scientiarum Agronomy, v. 40, p.1-9, 2018. DOI: 10.4025/actasciagron.v40i1.35290

[2] INSTITUTO ADOLFO LUTZ. Métodos físico-químicos para análise de alimentos. 5 ed. São Paulo: Instituto Adolfo Lutz, 2008. 1020 p.

[3] RUFINO M.S.M., ALVES R. E., BRITO, E. S., MANCINI F. J., MOREIRA A. V. B. Metodologia científica: Determinação da Atividade Antioxidante Total em Frutas no Sistema $\beta$-caroteno/Ácido Linoléico. Comunicado Técnico no 126. Fortaleza: EMBRAPA, 2006.

[4] RUFINO M.S.M., ALVES R.E., BRITO E.S., MORAIS S.M., SAMPAIO C.G., PÉREZ-JIMÉNEZ J.; SAURA-CALIXTO F.D. Metodologia Científica: Determinação da Atividade Antioxidante Total em Frutas pela Captura do Radical Livre ABTS. Comunicado Técnico no 127 . Fortaleza: EMBRAPA, 2007.

[5] SINGLETON, V.L., ROSSI, J.A. Colorimetry of total phenolics with phosphomolybdic-phosphotungstic acid reagents. American Journal of Enology Viticuture, v. 16, p. 144-158, 1965. 


\section{Capítulo 4}

\section{Influência do tempo de cocção nos teores de}

carotenóides totais de cinco variedades de pupunhas (Bactris gasipaes kunth)

Danyelly Silva Amorim

Isabelly Silva Amorim

Jamille de Sousa Monteiro

Ingryd Rodrigues Martins

Kássia Rodrigues da Costa Sena

Marcos Daniel das Neves Sousa

Maria Renara Alves Rodrigues

Francisca Mariane Martins Araújo

Ana Carla Alves Pelais

Resumo: Diante da importância da atuação dos carotenóides no organismo humano o trabalho teve por objetivo avaliar a influência de diferentes tempos de cocção nos teores de carotenóides totais em diferentes tipos de pupunhas no município de Castanhal - PA. Foram adquiridos cinco tipos diferentes de pupunhas de fornecedores no mercado local do município de Castanhal, PA. As pupunhas foram lavadas, sanitizadas e enxaguados em água corrente. 0 procedimento de cocção das pupunhas ocorreu em tempos 25 minutos e 30 minutos ao mesmo nível de chama, processo repetido para os cinco tipos de pupunhas. A extração dos carotenóides totais foi realizada com utilização de solução etanol-acetona $(1: 1 \mathrm{v} / \mathrm{v})$. Os resultados foram tratados pela análise de variância e as médias comparadas entre si pelo teste de Tukey, ao nível de 5\% de significância. As pupunhas in natura, antes do tratamento térmico (cocção) não apresentaram diferença estatística $(p<0,05)$, com exceção da amostra P4 e P5. As amostras P1, P3 e P4 não apresentaram diferença estatística $(p>0,05)$ no teor de carotenóides em relação aos tempos de cocção avaliados. 0 tempo de cocção influenciou estatisticamente $(p<0,05) 0$ teor de carotenoides nas amostras P2 e P5, elevando os teores com o aumento do tempo. 0 processo de cozimento em diferentes tempos não reduziu os teores de carotenóides totais nas pupunhas. Dessa forma, o tratamento térmico não age negativamente no quantitativo deste antioxidante nas pupunhas, sendo possível que haja melhora no conteúdo de carotenóides.

Palavras-chave: Carotenóides. Pupunhas. Tempo de cozimento. 


\section{INTRODUÇÃO}

As frutas são alimentos nutritivos que desempenham um papel fundamental na dieta humana. São ricas em vitamina C, provitamina A e vitaminas do grupo B. Estes alimentos são conhecidos por auxiliarem na redução do colesterol total e LDL no sangue (MUIMBA-KANKOLONGO, 2018).

A pupunha (Bactris gasipaes kunth) é uma fruta típica do norte do Brasil e possui altos teores de carboidratos, lipídios e vitamina A (BEZERRA; SILVA, 2016). É fonte de ácidos graxos essenciais e contem teores de ácidos graxos insaturados maiores quando comparados aos saturados (RESTREPO; ESTUPIÑÁN; COLMENARES, 2016). Sua coloração deve-se a presença de pigmentos naturais, como os carotenóides (MATOS et al., 2019).

Nos últimos anos estudos epidemiológicos mostram a relação da ingestão de alimentos ricos em compostos bioativos com a prevenção de doenças crônicas. Os antioxidantes têm como principal fonte as frutas, legumes e cereais, que são intitulados de ingredientes funcionais (COELHO; FERNANDES; SALASMELLADO, 2019).

Os carotenóides são pigmentos de caráter lipofílico de origem vegetal. O organismo humano não os sintetiza, por esse motivo, depende da ingestão de alimentos constituídos dos mesmos para usufruir de suas funções biológicas desejáveis (GRANADO-LORENCIO et al., 2017).

Uma característica que diferencia os carotenóides de outras substâncias é sua estrutura química constituída por uma cadeia de dupla ligação conjugada que forma um cromóforo responsável pelas cores características, que variam da tonalidade incolor (fitoeno), amarelo (luteína), laranja (b-caroteno) e vermelho (licopeno) (ARSCOTT, 2013; AMAH et al., 2019).

Diante da importância da atuação dos carotenóides no organismo humano o trabalho teve por objetivo avaliar a influência de diferentes tempos de cocção nos teores de carotenóides totais em diferentes tipos de pupunhas no município de Castanhal - PA.

\section{METODOLOGIA}

Foram adquiridos cinco tipos diferentes de pupunhas de fornecedores no mercado local do município de Castanhal, PA. As pupunhas, Figura 1, foram transportadas até o Laboratório de Alimentos da Universidade do Estado do Pará - UEPA, Campus Castanhal, onde foram lavadas, sanitizadas á 150 ppm com hipoclorito por 10 minutos e enxaguados em água corrente.

Para a cocção, foram pesados $100 \mathrm{~g}$ de pupunhas e adicionados $1 \mathrm{~L}$ de água em um recipiente de aço inoxidável. Ambos foram aquecidos em fogão industrial com diferentes tempos de cozimento, 25 minutos e 30 minutos ao mesmo nível de chama. Este procedimento foi repetido para os cinco tipos de pupunhas.

Figura 1 - Pupunhas adquiridas de diferentes fornecedores do município de Castanhal

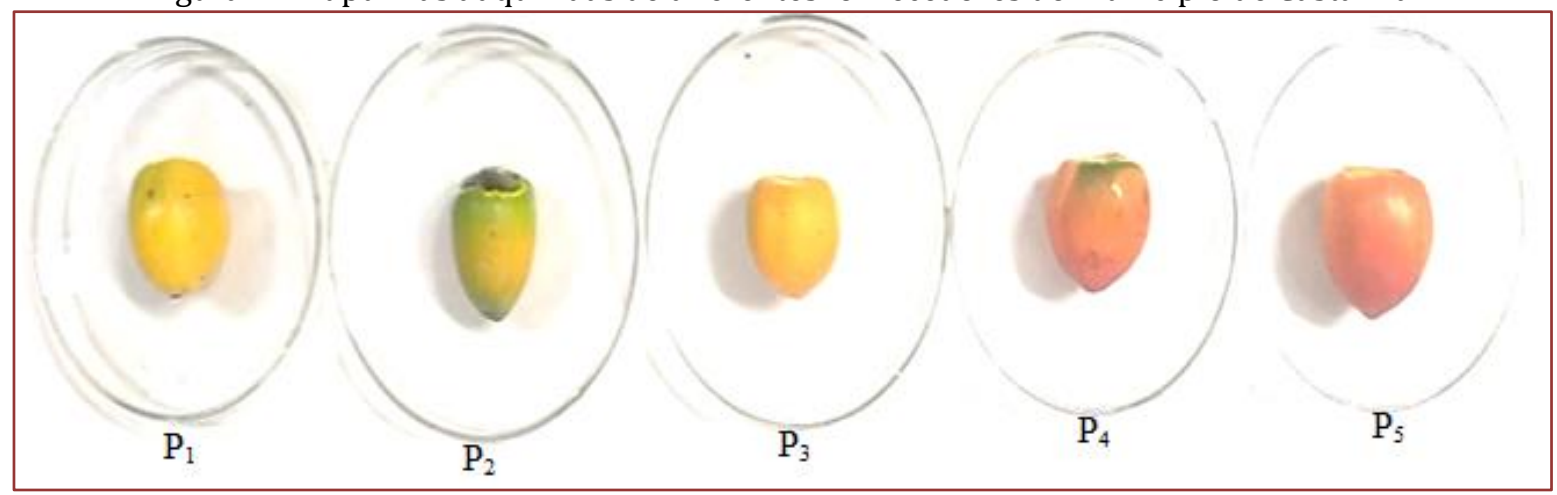

A extração dos carotenóides totais foi realizada de acordo com metodologia adaptada de Talcott e Howard (1999), com utilização de solução etanol-acetona (1:1 v/v). As amostras foram filtradas com esta solução até que o filtrado apresentasse coloração branca, Figura 2. 
Figura 2. Etapa de extração de carotenóides por solução etanol-acetona
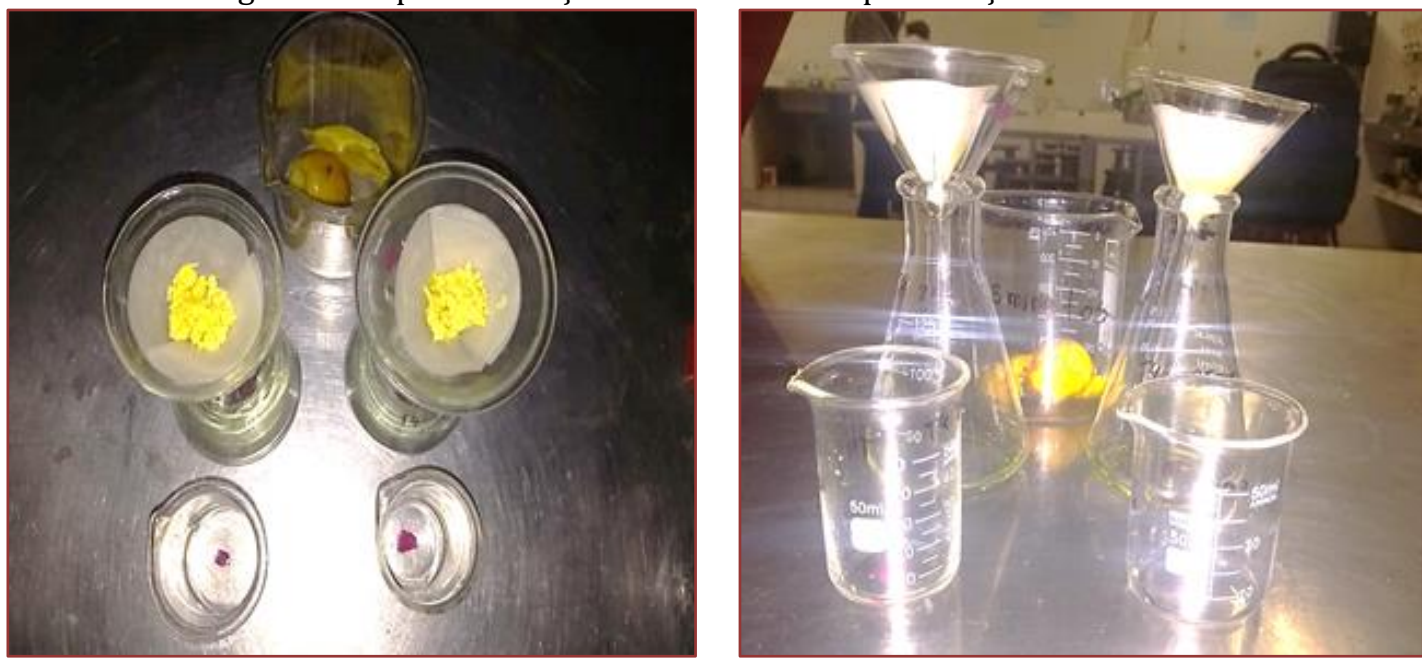

Em seguida, os extratos obtidos foram aferidos em balões volumétricos de $25 \mathrm{~mL}$ com a solução etanolacetona. As leituras das absorbâncias foram realizadas em espectrofotômetro a $450 \mathrm{~nm}$. Os valores encontrados são expressos em mg de carotenóides a cada 100 gramas de amostra, conforme Equação 1.

$$
\mathrm{C}=\frac{\mathrm{A} \times \mathrm{V} \times 10^{3}}{\mathrm{E} \times \mathrm{P}}
$$

Onde: $\mathrm{A}=$ absorbância lida; $\mathrm{V}=$ volume do solvente utilizado para a diluição da amostra; $\mathrm{E}=$ absortividade de 2000; $\mathrm{P}=$ quantidade da amostra.

Os resultados foram tratados pela análise de variância e as médias comparadas entre si pelo teste de Tukey, ao nível de 5\% de significância.

\section{RESULTADOS E DISCUSSÕES}

As pupunhas in natura, antes do tratamento térmico (cocção) não apresentaram diferença estatística ( $\mathrm{p}<$ $0,05)$, com exceção da amostra $\mathrm{P}_{4}$ e $\mathrm{P}_{5}$ (Tabela 1). A diferença de carotenóides entre as pupunhas analisadas neste trabalho deve-se provavelmente as diferenças de tonalidade das mesmas. Verificou-se que o teor de carotenoides foi superior nas amostras de coloração mais intensa. Quesada et al. (2011), ao quantificarem os carotenóides em duas variedades de pupunhas cruas encontram valores de $5,7 \mathrm{mg} / 100 \mathrm{~g}$ e 7,4 mg/100g, resultados que assemelham aos encontrados na $P_{5}$.

Tabela 1. Teor de carotenóides totais (mg /100g) em pupunhas cruas e com diferentes tempos de cozimento

\begin{tabular}{|c|c|c|c|}
\hline Pupunha & $\mathrm{T}_{1}$ & $\mathrm{~T}_{2}$ & $\mathrm{~T}_{3}$ \\
\hline $\mathrm{P}_{1}$ & $4,75 \pm 0,32^{\mathrm{aCD}}$ & $4,63 \pm 0,01 \mathrm{aCD}$ & $4,02 \pm 0,12^{\mathrm{aBCD}}$ \\
\hline $\mathrm{P}_{2}$ & $1,50 \pm 0,02^{\mathrm{aDE}}$ & $1,73 \pm 0,12^{\mathrm{bDE}}$ & $1,87 \pm 0,10^{\mathrm{bCD}}$ \\
\hline $\mathrm{P}_{3}$ & $2,54 \pm 0,07 \mathrm{aE}$ & $2,71 \pm 0,10^{\mathrm{aE}}$ & $2,74 \pm 0,18^{\mathrm{aD}}$ \\
\hline $\mathrm{P}_{4}$ & $10,70 \pm 0,41^{\mathrm{aA}}$ & $10,69 \pm 0,39 \mathrm{aA}$ & $11,71 \pm 0,95^{\mathrm{aA}}$ \\
\hline $\mathrm{P}_{5}$ & $7,66 \pm 0,85^{\mathrm{aB}}$ & $7,66 \pm 0,99 \mathrm{aB}$ & $11,55 \pm 0,56^{\mathrm{bAB}}$ \\
\hline
\end{tabular}

$\mathrm{T}_{1}$ : pupunha crua; $\mathrm{T}_{2}$ : pupunha cozida por 25 minutos; $\mathrm{T}_{3}$ : pupunha cozida por 30 minutos; Médias seguidas de letras minúsculas iguais na mesma linha não diferem entre si $(\mathrm{p}<0,05)$ para o tipo de tratamento; Médias seguidas de letras maiúsculas iguais na mesma coluna não diferem entre si $(\mathrm{p}<0,05)$ para o tipo de pupunha. 
Rosso e Mercadante (2007), realizaram a identificação e determinação de carotenóides em pupunhas expressando teor de $19,76 \mathrm{mg} / 100 \mathrm{~g}$, valor superior ao quantificado nas pupunhas do município de Castanhal, Pará, demonstrando que a variedade de pupunhas interfere no teor deste antioxidante.

As pupunhas $\mathrm{P}_{1}, \mathrm{P}_{3}$ e $\mathrm{P}_{4}$ não apresentaram diferença estatística $(\mathrm{p}>0,05)$ no teor de carotenóides em relação aos tempos de cocção avaliados. Jatunov et al. (2010), analisaram o teor total de carotenóides em seis variedades de pupunhas e encontraram resultados de $1,1 \mathrm{mg} / 100 \mathrm{~g}$ a $22,3 \mathrm{mg} / 100 \mathrm{~g}$ entre as amostras. Além de frisarem que a cocção dos frutos por 30 minutos não afetou o teor total de carotenóides.

0 tempo de cocção influenciou estatisticamente $(\mathrm{p}<0,05)$ o teor de carotenoides nas amostras $\mathrm{P}_{2}$ e $\mathrm{P}_{5}$, aumentando os teores com o aumento do tempo. Kourouma et al. (2019), ao analisarem diferentes processos de cozimento (fervura, cozedura a vapor, micro-ondas, torrefaç̧ão, fritura) em batata doce de polpa alaranjada ressaltaram que estes processos melhoraram a atividade antioxidante.

\section{CONCLUSÃO}

O processo de cozimento em diferentes tempos não reduziu os teores de carotenóides totais nas pupunhas. Dessa forma, o tratamento térmico não age negativamente no quantitativo deste antioxidante, sendo possível que haja melhora no conteúdo de carotenóides. Para validar a relação entre teor de carotenóides e tempo de cocção pesquisas com maior número amostral e tempos de cocção podem ser realizadas.

\section{REFERÊNCIAS}

[1] ARSCOTT, S. A. Food sources of carotenoids. In: S. A. Tanumihardjo (ed.). Carotenoids and human health. New York: Springer Science+Business Media, 2013.

[2] BEZERRA, C. V.; SILVA, L. H. M. Pupunha (Bactris gasipaes): general and consumption aspects. In: KRISTBERGSSON, K.; OLIVEIRA, J. Integrating food science and engineering knowledge into the food chain. Springer: Boston, 2016.

[3] COELHO, M. S.; FERNANDES, S. S.; SALAS-MELLADO, M. M. Association between diet, health, an the presence of bioactive compounds in foods. In: CAMPOS, M. R. S. (ed.). Bioactive compounds: health benefits and potential applications. Cambridge: Woodhead Publishing, 2019.

[4] FERNANDES, S. S.; COELHO, M. S.; SALAS-MELLADO, M. M. Bioactive compounds as ingredients of functional foods: polyphenols, carotenoids, peptides from animal and plant sources new. In: CAMPOS, M. R. S. (ed.). Bioactive Compounds: Health Benefits and Potential Applications. Cambridge: Woodhead Publishing, 2019.

[5] GRANADO-LORENCIO, F. et al. Biomarkers of carotenoid bioavailability. Food Research International, v. 99, p. 902-916, 2017.

[6] JATUNOV, S. et al. Carotenoid composition and antioxidant activity of the raw and boiled fruit mesocarp of six varieties of Bactris gasipaes. Sociedad Latinoamericana de Nutrición, v. 60, n. 1, p. 99-104, 2010.

[7] KOUROUMA, V. et al. Effects of cooking process on carotenoids and antioxidant activity of orangefleshed sweet potato. LWT - Food Science and Technology, v. 104, p. 134-141, 2019.

[8] MATOS, K. A. N. et al. Peels of tucumã (Astrocaryum vulgare) and peach palm (Bactris gasipaes) are byproducts classified as very high carotenoid sources. Food Chemistry, v. 272, p. 216-221, 2019.

[9] MUIMBA-KANKOLONGO, A. Food crop production by smallholder farmers in Southern Africa. Cambridge: Academic Press, 2018.

[10] QUESADA, G. et al. Carotenoids composition, antioxidant activity and glycemic index of two varieties of Bactris gasipaes. Emirates Journal of Food and Agriculture, v. 23, n. 6, p. 482-489, 2011.

[11] RESTREPO, J.; ESTUPIÑÁN, J. A.; COLMENARES, A. J. Estudio comparativo de las fracciones lipídicas de Bactris gasipaes Kunth (chontaduro) obtenidas por extracción soxhlet y por extracción con $\mathrm{CO} 2$ supercrítico. Revista Colombiana de Química, v. 45, n. 1, p. 5-9, 2016.

[12] ROSSO, V.V.; MERCADANTE, A.Z. Identification and quantification of carotenoids, by HPLC-PDA-MS/MS, from Amazonian fruits. Journal of Agricultural and Food Chemistry, v.55, n.13, p.5062-5072, 2007.

[13] TALCOTT, S. T.; HOWARD, L. R. Phenolic autoxidation is responsible for color degradation in processed carrot puree. Journal of Agricultural and Food Chemistry, v. 47, p. 2109-2115, 1999. 


\section{Capítulo 5}

Influência do pH e da adição de carboximetilcelulose sobre a fabricação e propriedades de filmes a base de proteina de soja

\section{Jaqueline dos Santos de Oliveira \\ Angela Maria Picolloto \\ Laís Ravazzi Amado \\ Keila de Souza Silva}

Resumo: Na busca de alternativas para as embalagens derivadas do petróleo, vem se destacando os filmes comestíveis. A junção de proteína e polissacarídeo, e a otimização de parâmetros como $\mathrm{pH}$, podem se mostrar excelentes alternativas para aumentar as propriedades funcionais dos filmes. Este trabalho teve como objetivo analisar as propriedades dos filmes de proteína isolada de soja (SPI) com e sem a adição de carboximetilcelulose (CMC), variando o $\mathrm{pH}$ do meio. Os filmes produzidos foram com $5 \%$ de SPI, 2\% de glicerina com e sem adição de 0,375\% de CMC em 6 formulações diferentes de pH. Os pHs investigados foram: 3 4; 5; 6; 7; 8; 9; 10 e 11. A adição do polissacarídeo aumentou a solubilidade, reduziu a transparência dos filmes, aumentou a barreira ao vapor de água e no pH 11 apresentou a melhor microestrutura.

Palavras-Chave: filme biodegradável; soja; goma carboximetilcelulose; pH; proteína. 


\section{INTRODUÇÃO}

Com o intuito de diminuir o impacto no meio ambiente, os filmes biodegradáveis se destacam por ser um excelente substituinte dos plásticos convencionais. Esses filmes são fabricados por materiais biodegradáveis não tóxicos, portanto sua utilização não é prejudicial (PACHEKOSKI et al. 2014). Além disso, podem ser degradados com facilidade quando submetidos à ideais situações de umidade, microrganismos no solo e oxigênio. Quando esses filmes são produzidos por biopolímeros como proteína, polissacarídeo e/ou lipídeo, pode também ser comestíveis (OLIVAS \& BARBOSA-CÀNOVAS, 2005).

A proteína de soja isolada (SPI) e a carboximetilcelulose (CMC) são ótimas opções de proteína e goma, respectivamente, para a fabricação de filmes biodegradáveis.

O Brasil é o maior produtor de soja do mundo, com mais de 118 milhões de tonelada na safra de 2018 (CONAB, 2018). A proteína de soja, subproduto da produção de óleo de soja, é muito utilizada como ingrediente para fabricação de carnes picada e agente emulsificante e texturizante como em queijo, pães e massas em geral (NISHINARI et al., 2018). Essa proteína também proporciona amplo potencial na substituição de produtos à base de petróleo devido sua disponibilidade e baixo custo (GUERRERO et al., 2011).

A proteína de soja é comercializada na forma de farinha de soja, proteína de soja concentrada e proteína isolada de soja (SPI). A SPI é proveniente da produção da farinha de soja e possui cerca de $90 \%$ de teor proteico (SONG et al., 2011). A SPI apresenta ótima biodegradabilidade, biocompatibilidade e capacidade de formação de filmes, com propriedades mecânicas moderadas e uma boa propriedade de barreira ao óleo, permitindo eficiência em seu revestimento ao alimento (MILLER et al., 1997; CHO et al., 2010; WANG et al., 2012; CIANNAMEA et al., 2014). Ao ser submetida em solução aquosa seu ponto isoelétrico (pI) é na faixa de 4,5-5,0 (JARAMILLO et al., 2011; AMADO et al., 2019), e os filme elaborados abaixo do pI apresentam interação eletrostática com polissacarídeos aniônicos por estarem carregados positivamente (AMADO et al., 2019).

Caracterizada por ser um polímero em grande quantidade na natureza, a carboximetilcelulose (CMC) é uma matéria-prima barata, estável quimicamente, não tóxica e biodegradável (WANG et al., 2016). Ela apresenta grupos hidroxilas que favorecem o aumento de sua solubilidade por meio dos éteres e ésteres de celulose (DHALL, 2013).

A CMC está sendo muito utilizada para a fabricação de filmes biodegradáveis, isso está acontecendo devido suas películas apresentarem características apropriadas em aplicações como filmes em alimentos. Filmes produzidos a partir de CMC são mais transparentes e apresentam baixa opacidade, permeabilidade ao vapor de água entre $10^{-9}$ e $10^{-10}$, e boa flexibilidade e resistência a tração (OUN et al., 2015; MOHAMMADI et al., 2018; RODSAMRAN et al., 2017; BALLESTEROS et al., 2018). Além disso, CMC é uma goma muito compatível com proteína, sua interação pode ajudar na solubilidade proteica e ser capaz de estabilizar a solução conforme condições de pH, força iônica e relação estequiométrica (FEDDERSEN, 1993).

Já se possui várias pesquisas sobre a interação entre proteína de soja e polissacarídeos como pectina (AMADO et al., 2019), ágar (KIM \& NETRAVALI, 2012) e goma guar (SUI et al., 2016) para formação de filmes, porém, estudos abordando características de filmes de SPI com adição da CMC em condições específicas e suas propriedades ainda são escassos.

A influência do pH em filmes compostos de biopolímeros também não tem sido muito explorada, e sabe-se que esta é uma variável que afeta de forma significativa a formação de filmes biodegradáveis (MAURI; ANÕN, 2006). Rocha et al. (2014) elaboraram filmes com amido de mandioca e extrato proteico de soja e verificaram que o $\mathrm{pH}$ influenciou nas propriedades dos mesmos, e considerando alguns fatores desejáveis encontraram um pH ótimo para as condições do trabalho, que no caso foi pH 6,1. No entanto, dependendo do polímero e plastificante utilizados, assim como das concentrações de cada componente e metodologia empregada esse valor de $\mathrm{pH}$ pode ser alterado.

Diante do exposto, o objetivo do presente trabalho foi desenvolver e caracterizar filmes compostos de SPI e CMC, alterando o pH da solução. A Influência da adição do polissacarídeo e da variação do $\mathrm{pH}$ foi avaliada sobre propriedades de barreira (ao vapor de água e a luz), solubilidade e microestrutura. 


\section{MATERIAIS E MÉTODOS}

\subsection{PREPARAÇÃO DA SOLUÇÃO FILMOGÊNICA}

As soluções dos filmes foram preparadas a partir da mistura da proteína isolada de soja (SPI - 5\%), glicerol (2\%), sem e com adição de carboximetilcelulose (CMC - 0,375\%) em água destilada. 0 pH da solução foi corrigido para 11 usando $\mathrm{NaOH}(20 \%)$ e, logo após, a solução foi aquecida a $65^{\circ} \mathrm{C}$ por 10 minutos para dissolver toda a proteína. Em seguida, solução de $\mathrm{HCl}$ (20\%) foi utilizada para a redução do pH da solução em distintos valores $(3 ; 4 ; 5 ; 6 ; 7 ; 8 ; 9 ; 10$ e 11). Soluções com pH reduzido e solução sem alteração do pH $(\mathrm{pH} 11)$ foram agitadas por 2 horas e encaminhadas ao tratamento térmico a $80^{\circ} \mathrm{C} / 20 \mathrm{~min}$. Em seguida, a solução foi resfriada em bandeja de polipropileno e colocadas para secar em estufa com circulação e renovação de ar à 35ํㄷ/16h. Previamente as análises, os filmes secos foram acondicionados em ambiente a $25^{\circ} \mathrm{C}$ e $53 \%$ UR por aproximadamente uma semana.

\subsection{ESPESSURA}

A análise de espessura dos filmes foi realizada utilizando um micrômetro digital (Western, MC-3, China). Corpos de prova utilizados para permeabilidade ao vapor de água e propriedade ótica foram medidos em 4 pontos diferentes, escolhidos aleatoriamente.

\subsection{PERMEABILIDADE AO VAPOR DE ÁGUA (PVA)}

A PVA dos filmes foi realizada em triplicata segundo metodologia ASTM E96-95 (ASTM E96-95, 1995). Filmes foram cortados e fixados na abertura circular de células de permeação parcialmente preenchidas com cloreto de cálcio anidro (2\% UR). Em seguida, estas foram inseridas em dessecadores contendo água destilada (100\% UR), expostos a temperatura ambiente $\left(25^{\circ} \mathrm{C}\right)$. Células de permeação foram pesadas em intervalos de 40 minutos durante um período de 6 horas. A PVA foi calculada $\mathrm{em} \mathrm{g} \cdot(\mathrm{m} \cdot \mathrm{s} \cdot \mathrm{Pa})^{-1}$, utilizando a Equação 1.

$$
\mathrm{PVA}=\frac{\mathrm{TPVA} \cdot \mathrm{x}}{\mathrm{A} \cdot \mathrm{P}_{\mathrm{S}} \cdot\left(\left(\mathrm{URE}_{\mathrm{H}_{2} \mathrm{O}}-\mathrm{URE}_{\mathrm{CaCl}_{2}}\right) / 100\right)}
$$

em que: x é a espessura média dos filmes, em m, A é a área de permeação da cápsula $\left(28,14 \cdot 10^{-2} \mathrm{~m}^{2}\right) ; \mathrm{P}_{\mathrm{s}}$ é pressão de saturação do vapor de água a $25^{\circ} \mathrm{C}$ (3169 Pa); URE é a umidade relativa de equilíbrio no interior do dessecador $\left(\mathrm{H}_{2} \mathrm{O}\right)$ e no interior da cápsula $\left(\mathrm{CaCl}_{2}\right)$.

\subsection{SOLUBILIDADE EM ÁGUA}

A determinação da solubilidade dos filmes foi realizada, em triplicata, pela metodologia proposta por Cuq et al. (1996). Filmes cortados em quadrados $(2 \times 2 \mathrm{~cm})$ foram pesados, secos e em seguida imersos em $50 \mathrm{~mL}$ de água à temperatura ambiente e com agitação de $60 \mathrm{rpm}$. Após 24 horas, as amostras foram retiradas da solução e secas a $105^{\circ} \mathrm{C}$ até atingir peso constante. A solubilidade, S, foi calculada de acordo com a Equação 2.

$$
\mathrm{S}=\frac{\mathrm{W}_{0}-\mathrm{W}_{\mathrm{f}}}{\mathrm{W}_{0}} \times 100
$$

em que: $\mathrm{W}_{0}$ corresponde a matéria seca inicial e $\mathbf{W}_{\mathrm{f}}$ a matéria seca final, após imersão em água.

\subsection{PROPRIEDADE ÓTICA}

Esta propriedade dos filmes foi realizada através de espectrofotômetro UV-Visível (FEMTO, 700 plus, São Paulo) no comprimento de onda de $600 \mathrm{~nm}$. A transparência das amostras foi expressa como uma relação entre a medida de absorbância e a média da espessura dos filmes (Equação 3). Os mesmos foram cortados proporcionalmente à cubeta na qual foram colocados para serem feitas as respectivas leituras. 


$$
\text { Opacidade }=\frac{\mathrm{A}_{600}}{\mathrm{X}}
$$

em que: $\mathrm{A}_{600}$ é a absorbância a $600 \mathrm{~nm}$ e X a espessura média, em mm.

\subsection{MICROESTRUTURA}

A microscopia eletrônica de varredura foi realizada em Microscópio Eletrônico de Varredura (MEV) de bancada (SEI modelo Quanta 250), operando com uma tensão de aceleração de elétrons de 5kV.

\subsection{ANÁLISE ESTATÍSTICA}

As réplicas das análises foram expressas na forma de média \pm desvio, e as médias foram avaliadas estatisticamente mediante Análise de Variância (ANOVA) e Teste de Tukey, considerando-se um nível de significância de 0,05.

\section{RESULTADOS E DISCUSSÃO}

\subsection{ANÁLISE VISUAL}

Filmes com e sem a adição da carboximetilcelulose (CMC) nos pHs 3; 4 e 5 (Figura 1) apresentaram pequenos buracos e rasgos em sua estrutura, evidenciados principalmente no filme de SPI no pH 5 (Figura 1F). Tal fato pode ser justificado pela proximidade desse $\mathrm{pH}$ com o ponto isoelétrico (pI) da SPI, uma vez que no pI a coagulação não permite a formação de uma matriz homogênea (ROCHA et al., 2014; MAURI; AÑON, 2006).

No geral, observou-se que as descontinuidades foram menores em filmes com acréscimo da goma. Em pHs abaixo do pI da proteína de soja (entre 4,5 e 5), esta apresenta cargas positivas em evidência que podem ter interagido com a carga negativa do polissacarídeo através de interação eletrostática (AMADO et al., 2019), aumentando a coesão da rede. CMC apresenta pKa de aproximadamente 2,3 (CARPINETI et al., 2014), portanto, em toda faixa de $\mathrm{pH}$ avaliada possui carga líquida negativa.

Figura 1 - Filmes de SPI+CMC (A, B e C) e filmes de SPI (D, E e F), alternando o pH: A e D - pH 3; B e E - pH 4 e $\mathrm{C}$ e F - pH 5

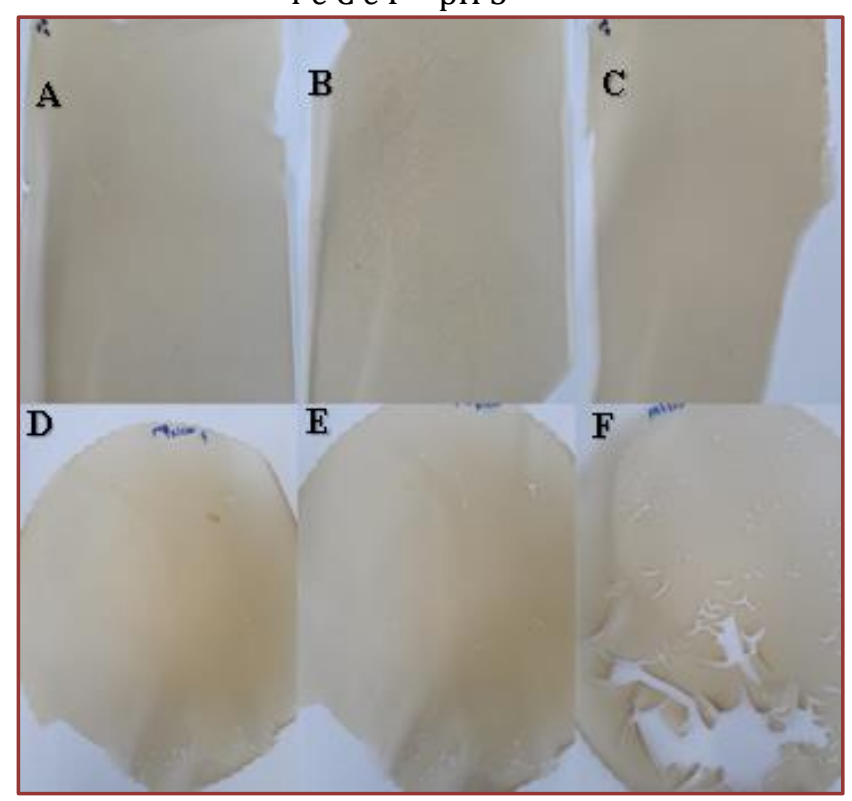




\subsection{PVA E SOLUBILIDADE DOS FILMES DE SPI E SPI+CMC}

Os resultados de PVA e solubilidade dos filmes de SPI e SPI+CMC, nos diferentes pHs $(6 ; 7 ; 8 ; 9 ; 10$ e 11), estão expressos na Tabela 1.

Tabela 1 - PVA e solubilidade dos filmes SPI e SPI+CMC em diferentes pHs

\begin{tabular}{|c|c|c|c|c|}
\hline & SPI & \multicolumn{3}{|c|}{$\mathrm{SPI}+\mathrm{CMC}$} \\
\hline Filmes & $\begin{array}{c}\mathrm{PVA} \times 10^{10} \\
\left(\mathrm{~g} \cdot \mathrm{m}^{-1} \cdot \mathrm{s}^{-1} \cdot \mathrm{Pa}^{-1}\right)\end{array}$ & Solubilidade & $\begin{array}{c}\mathrm{PVA} \times 10^{10} \\
\left(\mathrm{~g} \cdot \mathrm{m}^{-1} \cdot \mathrm{s}^{-1} \cdot \mathrm{Pa}^{-1}\right)\end{array}$ & Solubilidade (\%) \\
\hline SPI 6 & $8,60 \pm 0,37 a b, A$ & $49,83 \pm 1,88^{\mathrm{b}, \mathrm{A}}$ & $9,71 \pm 0,06^{a c, ~ A ~}$ & $63,83 \pm 1,66^{\mathrm{b}, \mathrm{B}}$ \\
\hline SPI 7 & $7,81 \pm 0,01^{\mathrm{a}, \mathrm{A}}$ & $40,63 \pm 0,88^{a, A}$ & $8,37 \pm 0,85^{a b, ~} A$ & $56,52 \pm 1,89 a$, в \\
\hline SPI 8 & $7,78 \pm 0,46^{\mathrm{ab}, \mathrm{A}}$ & $39,92 \pm 1,97 \mathrm{a}, \mathrm{A}$ & $7,42 \pm 0,14 \mathrm{~b}, \mathrm{~A}$ & $54,75 \pm 0,86^{a, ~} B$ \\
\hline SPI 9 & $9,49 \pm 0,84^{a b, ~ A ~}$ & $47,88 \pm 1,30^{\mathrm{b}, \mathrm{A}}$ & $8,81 \pm 0,47 \mathrm{ab}, \mathrm{A}$ & $55,92 \pm 1,27 \mathrm{a}, \mathrm{B}$ \\
\hline SPI 10 & $9,50 \pm 0,82^{\mathrm{b}, \mathrm{A}}$ & $41,40 \pm 0,64 \mathrm{a}, \mathrm{A}$ & $10,10 \pm 0,45$ ac,, & $57,33 \pm 0,80^{a}, \mathrm{~B}$ \\
\hline SPI 11 & $8,69 \pm 0,70 \mathrm{ab}, \mathrm{A}$ & $56,30 \pm 1,97 \mathrm{c}, \mathrm{A}$ & $11,11 \pm 0,89 c, \mathrm{~B}$ & $63,40 \pm 0,86^{b, A}$ \\
\hline
\end{tabular}

De acordo com os dados fornecidos na Tabela 1, não foi possível observar uma tendência clara na PVA dos filmes de SPI e SPI+CMC em diferentes pHs. Nos filmes simples, sem adição do polissacarídeo, a única diferença significativa $(\mathrm{p}<0,05)$ observada foi em relação aos pHs 7 e 10, uma vez que no pH 10 a PVA foi significativamente maior do que no $\mathrm{pH}$ 7. Já nos filmes compostos (SPI+CMC) foram encontradas diferenças significativas nas médias obtidas no pH 8 em relação as médias dos pHs 6, 10 e 11, sendo a PVA no pH 8 significativamente menor ( $\mathrm{p}<0,05)$, e do pH 11 em relação aos pHs 7 a 9, sendo a média obtida no pH 11 significativamente maior $(\mathrm{p}<0,05)$.

Ao analisar a influência da adição de CMC na PVA dos filmes de SPI notou-se que, exceto para os pHs 8 e 9, os filmes compostos apresentaram menor barreira ao vapor de água comparados aos filmes simples. Portanto, pode-se aferir que a CMC não contribuiu de forma positiva para barreira ao vapor da água. Tal fato pode estar relacionado com a natureza hidrofílica do polissacarídeo adicionado ao filme, que pode ter desestabilizado parcialmente a matriz proteica (MARTELLI et al., 2017; TIAN et al., 2018). Outros autores, como Sui et al. (2016) e Silva et al. (2020) também observaram aumento da PVA de filmes de proteína de soja com acréscimo de polissacarídeo, no caso, goma alfarroba e goma guar, respectivamente.

Em relação a solubilidade, também não foi observado uma tendência clara nos resultados com a variação do $\mathrm{pH}$ nos filmes de SPI e SPI+CMC. Nos filmes elaborados apenas com SPI pode-se notar que o pH 11 proporcionou uma solubilidade ao filme significativamente maior $(p<0,05)$ do que os demais pHs. Provavelmente pode ter ocorrido por ser o filme elaborado no pH mais distante do ponto isoelétrico da proteína de soja (aproximadamente 4,5), ponto na qual a solubilidade é expressivamente inferior (BOURTOOM et al., 2006; FREITAS; ALBANO; TELIS, 2017). Em contrapartida, nos filmes elaborados com SPI e CMC maiores valores de solubilidade foram observados nos extremos de pH estudados (pH 6 e 11), sendo ambos estatisticamente iguais entre si e diferentes dos demais.

A respeito da adição do polissacarídeo sob a solubilidade dos filmes, observou-se que seu acréscimo aumentou a solubilidade do filme proteico em todos os pHs estudados, sendo os maiores aumentos observados nos pHs 7 (39,1\%), 8 (37,1\%) e 10 (38,5\%). Esses resultados podem estar relacionados a presença de grupos hidroxilas na estrutura da CMC que permitiram modificações químicas que aumentasse a solubilidade do filme através dos éteres e ésteres de celulose (DHALL, 2013). Guerrero et al. (2013) adicionaram ágar a filmes de SPI em duas diferentes concentrações no pH 10 e, assim como no presente trabalho, notaram aumento significativo da solubilidade dos filmes. Segundo os autores o resultado obtido com a maior concentração de ágar avaliada poderia indicar excesso de polissacarídeo na formulação, que não interagiu com a proteína e se dissolveu quando imerso em água. Tal fato pode ter ocorrido também com a adição de 0,375\% de CMC (Tabela 1), o que pode ser corroborado com as imagens do MEV adiante (Figura 3), na qual é possível notar que, exceto para o pH 11, o polissacarídeo provocou heterogeneidade nos filmes. $\mathrm{O} \mathrm{pH} 11$ foi o que ocasionou menor aumento na solubilidade dos filmes com CMC (12,6\%), o que pode indicar uma melhor interação entre os biopolímeros nesse pH. 


\subsection{OPACIDADE DOS FILMES DE SPI E SPI+CMC}

A Figura 2 a seguir estabelece a relação da opacidade dos filmes de SPI e SPI+CMC nos pHs 6 a 11.

Figura 2 - Opacidade dos filmes de SPI e SPI+CMC

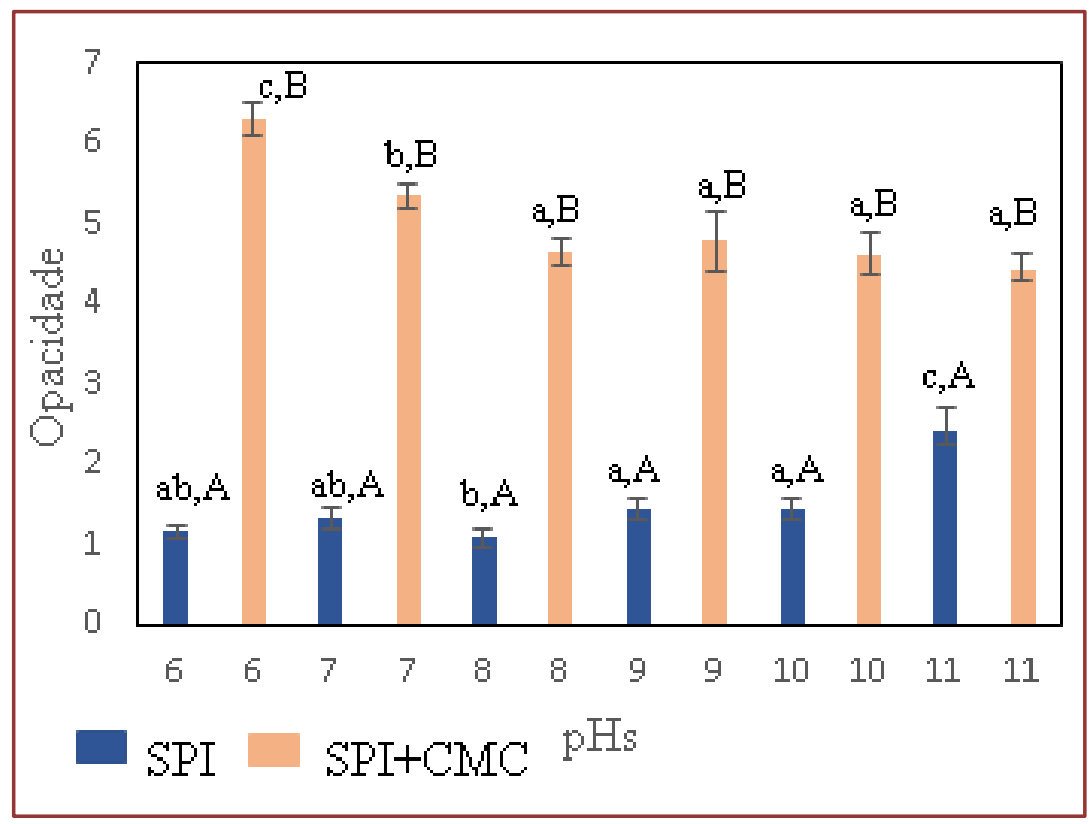

Com relação a opacidade dos filmes de SPI notou-se que o de pH 11 é 42\% menos transparente que o de pH 6. Já nos filmes compostos (SPI+CMC) foi no $\mathrm{pH} 6$ em que se obteve significativamente a menor transparência.

Ao compararmos os filmes sem goma e os filmes com CMC, nota-se que a adição da goma reduziu ao aumentar o pH: $(81,75,76,70,69$ e 45)\%, respectivamente, a transparência dos filmes, o que pode fornecer uma base sólida para a futura aplicação desses filmes em embalagens de alimentos, isso porque muitos produtos alimentícios podem ter alteração de cor, fotólises de aminoácidos e até mesmo perda de vitaminas devido à oxidação potencializada pela presença de luz. Embalagens opacas podem impedir o contato da luz com o alimento embalado (SLATER et al., 2000).

A influência da adição de polissacarídeos em filmes de proteína vem sendo estudada, e vários autores também encontraram aumento da opacidade com o acréscimo de polissacarídeo na formulação, entre eles estão Sui et al., (2015) e González et al. (2019) que adicionaram goma guar e galactomanana, respectivamente, em filme de SPI, e Silva et al. (2020) com adição de goma alfarroba em filmes de SPC.

\subsection{MICROESTRUTURA}

A figura 3 apresenta amicroestrutura dos filmes de SPI+CMC em diferentes pHs na faixa de 6 a 11 . As imagens analisadas foram ampliadas 2000 vezes.

Ao serem analisadas as imagens dos filmes de SPI+CMC estudados neste trabalho, notou-se que a melhor microestrutura foi obtida no $\mathrm{pH}$ 11, uma vez que sua micrografia (Figura 3F) apresentou matriz filmogênica de estrutura regular, homogênea, lisa e densa. Portanto, o pH 11 ocasionou uma melhor interação da SPI com o polissacarídeo e o plastificante.

A estrutura dos filmes de SPI com adição de CMC na concentração de $0,375 \%$ foi influenciada pelos diferentes pHs empregados. Os valores de pH abaixo de 10 deixaram a estrutura do filme mais rugosa. Portanto, os pHs entre 6 e 10 e a adição de CMC podem levar a uma má organização da rede da SPI. Nesses pHs observou-se zonas mais elevadas que outras, principalmente nos pHs 8 e 9, o que pode indicar um agrupamento de proteína em uma determinada região e de polissacarídeo em outra, assim como já observado com outras misturas de biopolímeros, como proteína do soro de leite / pectina (SILVA et al., 2018) e SPC / goma alfarroba (SILVA et al., 2020). 
Figura 3 - MEV dos filmes de SPI+CMC em diferentes pHs: A - pH 6; B - pH 7; C - pH 8; D - pH 9; E - pH 10 e F - pH 11. Vista com aumento de $2000 \mathrm{x}$

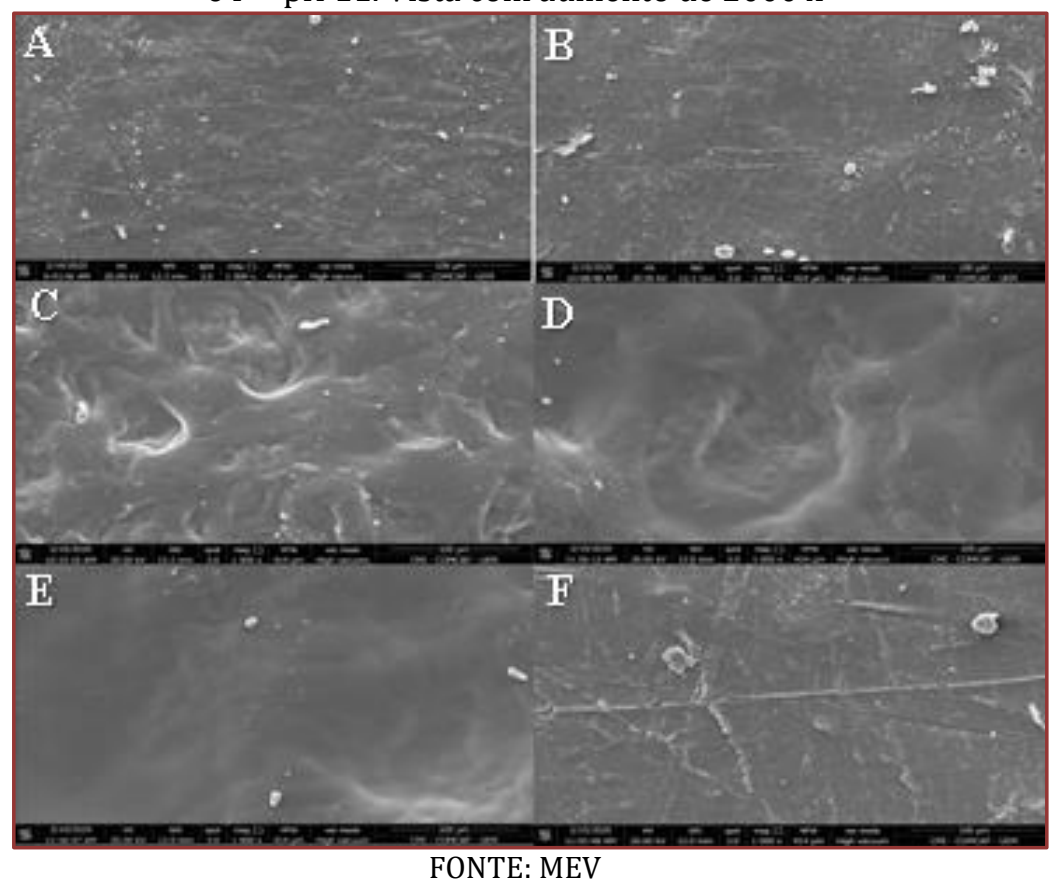

\section{CONCLUSÕES}

Não foi possível obter filmes propícios para análises nos filmes de pH 3, 4 e 5.

Os filmes compostos apresentaram menor PVA, maior solubilidade conforme aumentou-se o $\mathrm{pH}$, reduzindo a transparência dos filmes. E foi no pH 11 em que se obteve a melhor microestrutura.

\section{AGRADECIMENTOS}

Os autores agradecem ao COMCAP e Financiadora de Estudos e Projetos (FINEP) pelo uso dos equipamentos de metalização e MEV, ao CNPq (Processo 405406/20169) e a Fundação Araucária (Proc. 10884/2016) pelo apoio financeiro. Agradecem, ainda, ao Programa Institucional de Bolsas de Iniciação Científica PIBIC/CNPq-FUNDAÇÃO ARAUCÁRIA-UEM pela bolsa de iniciação científica concedida.

\section{REFERÊNCIAS}

1) AMADO, L. R.; SILVA, K. S.; MAURO, M. A. Effects of interactions between soy protein isolate and pectin on properties of soy protein-based films. Journal of Applied Polymer Science, v. 197 (21), 2019.

2) ASTM INTERNATIONAL. ASTM E96-95: Standard test methods of water vapor transmission of materials. In: Annual Book of ASTM Standards, American Society for Testing and Materials, Philadelphia, 1995.

3) BALlESTEROS, L. F.; CERQUEIRA, M. A.; TEIXEIRA, J. A.; MUSSATTO, S. I. Production and physicochemical properties of carboxymethyl cellulose films enriched with spent coffee grounds polysaccharides. International Journal of Biological Macromolecules, v. 106, p. 647-655, 2018.

4) BOURTOOM, T; CHINNAN, M. S.; JANTAWAT, P.\& SANGUANDEEKUL, R. - Lebenson Wiss Technol., 39, p.405, 2006.

5) CARPINETI, L.; MARTINEZ, M. J.; PILOSOF, A. M.; PÉREZ, O. E. $\beta$-lactoglobulin- carboxymethylcellulose coreshell microparticles: construction, characterization and isolation. Journal of Food Engineering, v. 131, p. 65-74, 2014.

6) CIANNAMEA, E. M.; STEFANI, P. M.; ROXANA, P. M.; RUSECKAITE, R. A. Physical and mechanical properties of compression molded and solution casting soybean protein concentrate based films. Food Hydrocolloids, v. 38, p. 193204, 2014.

7) CHO, S. Y.; LEE, S. Y.; RHEE, C. Edible oxygen barrier bilayer film pouches from corn zein and soy protein isolate for olive oil packaging. LWT - Food Science and Technology, v. 43, p. 1234-1239, 2010. 
8) COMPANHIA NACIONAL DE ABASTECIMENTO (CONAB). Acompanhamento da safra brasileira de grãos (Agosto 2018). Brasília: CONAB, n. 11, v. 5., 2018.

9) CUQ, B.; GONTARD, N.; CUQ, J.; GUILBERT, S. Functional Properties of Myofibrillar Protein-based Biopackaging as Affected by Film Thickness. Journal of Food Science, v. 61, n. 3, 1996.

10) DHALL, R. K. Advances in edible coatings for fresh fruits and vegetables: a review. Critical Reviews in Food Science and Nutrition, v. 53, p. 435-450, 2013.

11) FEDDERSEN, R. L. and Thorp, S. N. Sodium carboxymethylcellulose, In Industrial gums, polysaccharide and their derivatives (R. L. Whistler and J. N. Be Miller, eds.). San Diego, New York, Boston, USA: Academic Press, p. 537$578,1993$.

12) FREITAS, M. L. F., ALBANO, K. M., TELIS, V. R. N. Characterization of biopolymers and soy protein isolatehigh-methoxyl pectin complex. Polímeros, v. 27, p. 62-67, 2017.

13) GONZÁLEZ, A.; Barrera, G. N.; Galimberti, P. I.; Ribotta, P. D.; Igarzabal, C. I. A. Development of edible films prepared by soy protein and the galactomannan fraction extracted from Gleditsia triacanthos (Fabaceae) seed. Food Hydrocolloids, v. 97, p. 105227, 2019.

14) GUERRERO, P.; GARRIDO, T.; LECETA, I.; DE LA CABA, K. Films based on proteins and polysaccharides: Preparation and physical-chemical characterization. European Polymer Journal, v. 49, p.3713-3721, 2013.

15) GUERRERO, P.; STEFANI, P.M.; RUSECKAITE, R.A.; CABA, K. de La. Functional properties of films based on soy protein isolate and gelatin processed by compression molding. Journal of Food Engineering, v. 105, n. 1, p. 65-72, 2011.

16) JARAMILLO, D. P.; ROBERTS, R. F.; COUPLAND, J. N. Effect of pH on the properties of soy protein-pectin complexes. Food Research International, v. 44, p. 911-916, 2011.

17) KIM, J. T.; NETRAVALI, A. N. Physical properties of biodegradable films of soy protein concentrate/gelling agent blends. Macromolecular materials and Engineering, v. 297, p. 176-183, 2012.

18) MARTELLI, S. M.; MOTTA, C.; CAON, T.; ALBERTON, J.; BELLETTINI, I. C.; PRADO, A. C. P.; BARRETO, P. L. M.; SOLDI, V. Edible carboxymethyl cellulose films containing natural antioxidant and surfactants: a-tocopherol stability, in vitro release and film properties. LWT - Food Science and Technology, v. 77, p. 21-29, 2017.

19) MAURI, A. N.; AÑóN, M. C. Effect of solution pH on solubility and some structural properties of soybean protein isolate films. Journal of the Science of Food and Agriculture, v. 86, p. 1064-1072, 2006.

20) MILLER, K. S.; KROCHTA, J. M. Oxygen and aroma barrier properties of edible films: a review. Trends in Food Science and Technology, v. 8, 1997.

21) MOHAMMADI, H.; KAMKAR, A.; MISAGHI, A. Nanocomposite films based on CMC, okra mucilage and ZnO nanoparticles: Physico mechanical and antibacterial properties. Carbohydrate Polymers, v. 181, p. 351-357, 2018.

22) NISHINARI, K., FANG, Y., NAGANO, T., GUO, S., \& WANG, R. Soy as a food ingredient. Proteinsinfoodprocessing, p. 149-186, 2018.

23) OUN, A. A.; RHIM, Jong-Whan. Preparation and characterization of sodium carboxymethyl cellulose/cotton linter cellulose nanofibril composite films. Carbohydrate Polymers, v. 127, p. 107-109, 2015.

24) OLIVAS, G. I.; BARBOSA-CÁNOVAS, G. V. Edible coatings for fresh-cut fruits critical reviews. Food Science and Nutrition, v. 45, p. 657, 2005.

25) PACHEKOSKI, W. M.; DALMOLIN, C.; AGNELLI, J. A. M. Blendas poliméricas biodegradáveis de PHB e PLA para fabricação de filmes.Polímeros, São Carlos, v. 24, n. 4, p. 501-507, 2014.

26) ROCHA, G. O.; FARIAS, M. G.; CARVALHO, C. W. P.; ASCHERI, J. L. R.; GALDEANO, M. C. Filmes Compostos Biodegradáveis a Base de Amido de Mandioca e Proteína de Soja. Polímeros: Ciência e Tecnologia, v. 24, n. 5, p. 587$595,2014$.

27) RODSAMRAN, P.; SOTHORNVIT, R. Rice stubble as a new biopolymer source to produce carboxymethyl cellulose-blended films. Carbohydrate Polymers, v. 171, p. 94101, 2017.

28) SILVA, K. S.; FONSECA, T. M. R.; AMADO, L. R.; MAURO, M. A. Physicochemical and microstructural properties of whey protein isolate-based films with addition of pectin. Food Packaging and Shelf Life, v. 16, p. 122-128, 2018.

29) SILVA, K. S; MEDEIROS, K. A. S; AMADO, L. R; OLIVEIRA, M. M. G; PICOLLOTO, A. M; SAKAI, O. A. Interação entre goma alfarroba e proteína concentrada de soja na fabricação de filmes compostos biodegradáveis. In: Prática e pesquisa em ciência e tecnologia de alimentos 2, editora atena, Paraná, p. 99-110, 2020. 
30) SLATER, B.; MARTINS, B. T.; PHILIPPI, S. T. Rótulos e embalagens na indústria de alimentos. Brasil Alimentos, n. 1, p. 42-45, mar. 2000.

31) SONG, F.; TANG, D. L.; WANG, X. L.; WANG, Y. Z. Biodegradable soy protein isolatebased materials: a review. Biomacromolecules, v. 12, n. 10, p. 3369-3380, 2011.

32) SUI, C.; ZHANG, W.; YE, F.; LIU, X.; YU, G. Preparation, physical and mechanical properties of soy protein isolate/guar gum composite films prepared by solution casting. Journal of Applied Polymer Science, v.133, 43382, p. 19, 2016.

33) TIAN, H.; GUO, G.; FU, X.; YAO, Y.; YUAN, L.; XIANG, A. Fabrication, properties and applications of soy-proteinbased materials: A review. International Journal of Biological Macromolecules, v. 120, p. 475-490, 2018.

34) WANG, S.; LU, A.; ZHANG, L. Recent advances in regenerated cellulose materials. Progress in Polymer Science, v. 53, p. 169-206, 2016.

35) WANG, S.; MARCONE, M.; S. BARBUT, S. O impacto do extrato de framboesa vermelha rico em antocianina (ARRE) nas propriedades de filmes comestíveis de proteína de soja (SPI). Journal of Food Science, 77 (4)., Pp C497 C505, 2012. 


\section{Capítulo 6}

Eficiência da xantana pruni na produção de bolos sem glúten

\section{Leidi Daiana Preichardt \\ Claire Tondo Vendruscolo \\ Angelita da Silveira Moreira \\ Márcia Arocha Gularte}

Resumo: Objetivou-se, neste estudo, testar a eficiência do uso de xantana produzida por Xanthomonas arboricola pv pruni cepa 106 (XP) em bolos sem glúten. Os ingredientes utilizados foram farinha de arroz, farinha de milho, açúcar, leite pasteurizado, óleo de soja, fermento em pó, ovos e dois tipos de xantana: xantana pruni (XP) e xantana comercial (XC). Desta forma, foram desenvolvidas quatro formulações, duas com XC (F1 e F2) e duas com XP (F3 e F4), na proporção de 0,3\% (F1 e F3) e 0,4\% (F2 e F4). Também foram elaborados dois bolos controle sem xantana: um com formulação normal (C1) e outro com farinha de trigo no lugar da farinha de arroz (C2). A qualidade dos bolos foi monitorada através da determinação da composição centesimal, volume específico, firmeza e elasticidade. Para verificar possíveis diferenças sensoriais entre os bolos feitos com XP e XC foi aplicado um teste triangular com 30 painelistas. As duas xantanas (XP e XC) promoveram aumento no volume específico e proporcionaram bolos mais macios. 0 painel não notou diferença sensorial entre os bolos. Portanto, a xantana (XP) pode ser usada em bolos sem glúten sem comprometer suas características químicas e físicas, bem como a qualidade sensorial.

Palavras-chave: dieta para celíacos, farinha de arroz, farinha de milho, hidrocoloides, Xanthomonas arboricola pv pruni 106 


\section{INTRODUÇÃO}

A farinha de trigo é o principal ingrediente utilizado na fabricação de produtos de panificação, sua importância e aplicação se devem às características reológicas de extensibilidade e elasticidade atribuídas às proteínas do glúten (glutenina e gliadina). Alguns indivíduos, no entanto, apresentam uma predisposição genética (doença celíaca) que combinada com fatores ambientais (ingestão de glúten) e imunológicos, induz uma lesão inflamatória no intestino, atingindo as porções média e proximal do intestino delgado, ocasionando atrofia das microvilosidades e má absorção de nutrientes. A fração tóxica aos pacientes celíacos predominante no glúten é a de prolaminas, encontrada no trigo, cevada, centeio e aveia. As prolaminas no trigo são chamadas de gliadina, na cevada hordeína, no centeio secalina, e na aveia avenina. 0 elevado teor dos aminoácidos glutamina ( $>30 \%)$ e prolina $(>15 \%)$ nesses cereais proporciona uma toxicidade que não se observa com as prolaminas de cereais como arroz e milho, nas quais predominam os aminoácidos alanina e leucina (DANI, 2011).

Assim, a ciência e tecnologia dos alimentos tenta buscar ingredientes que apresentem características funcionais semelhantes ao glúten, sem prejuízo à qualidade dos alimentos e à saúde dos consumidores. A farinha de arroz vem sendo uma ótima opção como substituta da farinha de trigo em produtos de panificação sem glúten. A farinha de milho também pode ser utilizada para esse fim, mas ambas apresentam capacidade limitada para reter o ar e obter um volume adequado aos produtos.

A xantana possui excelentes propriedades reológicas para a utilização em alimentos. Auxilia na retenção de gás e no aumento do volume específico dos produtos de panificação. As xantanas empregadas na maioria das pesquisas voltadas para este tema são comerciais, produzidas por cepas de $X$. campestris pv campestris. No entanto, outras espécies de Xanthomonas também são capazes de produzir xatana, com eficiência e qualidade variável, como X. arboricola pv pruni (MOREIRA et al, 2001). Este trabalho teve por objetivo testar a eficiência tecnológica e adequabilidade sensorial da xantana produzida por X. arboricola pv pruni cepa 106, denominada xantana pruni 106, em bolos sem glúten.

\section{MATERIAIS E MÉTODOS}

Nas formulações dos bolos utilizou-se farinha de arroz (11\%), farinha de milho (11\%), açúcar (31\%), ovos $(22 \%)$, leite pasteurizado (18\%), óleo de soja (5\%), fermento químico (2\%), xantana comercial (XC) ou xantana pruni 106 (XP). Quatro formulações foram testadas, além das duas formulações controle sem xantana: F1 adicionada de $0,3 \%$ de xantana (XC), F2 adicionada de $0,4 \%$ de xantana (XC), F3 adicionada de $0,3 \%$ de xantana (XP), F4 adicionada de $0,4 \%$ de xantana (XP), C1 sem xantana e C2 com farinha de trigo em substituição a farinha de arroz e sem xantana. As concentrações de xantana foram calculadas com base no peso final da massa após a adição de todos os ingredientes. Os bolos foram assados em forno elétrico industrial a $200 \stackrel{\circ}{\circ} \mathrm{C}$ por $35 \mathrm{~min}$.

Determinou-se os parâmetros químicos de umidade, cinzas, proteína, lipídios, fibras (métodos 012/IV, 018/IV, 036/IV, 032/IV e 044/IV, respectivamente - IAL, 2004); os carboidratos foram determinados por diferença. Analisou-se também os parâmetros físicos de especial relevância tecnológica, volume específico $\left(\mathrm{cm}^{3} \cdot \mathrm{g}^{-1}\right)$, pela metodologia de deslocamento de grãos, e firmeza $(\mathrm{g})$ e elasticidade (\%) por medição em texturômetro (Stable Micro Systems, modelo TA-XT plus), com sonda P36R, compressão do modo de teste, velocidade pré-teste $1 \mathrm{~mm} / \mathrm{seg}$, velocidade pós-teste $10 \mathrm{~mm} / \mathrm{seg}$; tensão do modo alvo $25 \%$, tempo de espera $60 \mathrm{~s}$, tigger tipo auto (força) de 0,04903 $\mathrm{N}$.

0 teste triangular foi aplicado de acordo com Profiqua (2000) para verificar possíveis diferenças sensoriais entre os bolos feitos com duas diferentes concentração xantana XP e xantana XC. As avaliações foram realizadas por 30 painelistas.

\section{RESULTADOS E DISCUSSÃO}

A composição centesimal, apresentada na tabela 1, permaneceu praticamente a mesma em todas as formulações, com poucas variações. 
Tabela 1 - Composição centesimal (\%) e volume específico dos bolos $\left(\mathrm{cm}^{3} \cdot \mathrm{g}^{-1}\right)$

\begin{tabular}{|c|c|c|c|c|c|c|c|}
\hline Formulação & Umidade & Cinzas & Proteina & Lipídios & Fibras & Carboidratos & Vol esp. \\
\hline C1 & $34,72^{\mathrm{a}}$ & $0,95^{\mathrm{ab}}$ & $4,74^{\mathrm{b}}$ & $4,96^{\mathrm{a}}$ & $1,91^{\mathrm{a}}$ & $50,72^{\mathrm{a}}$ & $2,79^{\mathrm{c}}$ \\
\hline F1 & $36,85^{\mathrm{a}}$ & $0,88^{\mathrm{b}}$ & $5,31^{\mathrm{ab}}$ & $5,42^{\mathrm{a}}$ & $1,77^{\mathrm{a}}$ & $49,76^{\mathrm{a}}$ & $2,99^{\mathrm{b}}$ \\
\hline F2 & $36,35^{\mathrm{a}}$ & $1,01^{\mathrm{a}}$ & $5,13^{\mathrm{ab}}$ & $4,89^{\mathrm{a}}$ & $1,59^{\mathrm{a}}$ & $51,02^{\mathrm{a}}$ & $3,02^{\mathrm{ab}}$ \\
\hline F3 & $36,98^{\mathrm{a}}$ & $0,96^{\mathrm{ab}}$ & $4,82^{\mathrm{ab}}$ & $5,72^{\mathrm{a}}$ & $1,85^{\mathrm{a}}$ & $49,67^{\mathrm{a}}$ & $2,78^{\mathrm{c}}$ \\
\hline F4 & $36,8^{\mathrm{a}}$ & $0,98^{\mathrm{ab}}$ & $4,87^{\mathrm{ab}}$ & $5,78^{\mathrm{a}}$ & $1,89^{\mathrm{a}}$ & $49,32^{\mathrm{a}}$ & $2,88^{\mathrm{bc}}$ \\
\hline C2 & $36,08^{\mathrm{a}}$ & $0,98^{\mathrm{ab}}$ & $5,69^{\mathrm{a}}$ & $5,82^{\mathrm{a}}$ & $1,99^{\mathrm{a}}$ & $49,44^{\mathrm{a}}$ & $3,16^{\mathrm{a}}$ \\
\hline \multicolumn{7}{c}{}
\end{tabular}

Inesperadamente, o teor de cinzas diferiu estatisticamente entre as formulações $\mathrm{F} 1$ e F2, provavelmente por algum desvio na técnica. Já o teor proteico diferiu estatisticamente entre as formulações $\mathrm{C} 1$ e C2, feitas com farinhas (arroz e trigo, respectivamente) com diferentes teores de proteína. Como esperado, a xantana XP não alterou a composição centesimal dos bolos, e não houve diferença significativa entre a composição dos bolos feitos com xantana XC e xantana XP. 0 volume específico de F2 (maior concentração de XC) foi equivalente ao C2 (com farinha de trigo). 0 bolo F4 (maior concentração de XP) teve volume estatisticamente igual ao F1 (menor concentração de XC). Esses resultados demonstram a eficiência da xantana para proporcionar um volume adequado em bolos sem glúten e a potencialidade da xantana XP para esse fim.

Embora não tenha sido verificada diferença significativa na umidade dos bolos (Tabela 1), a adição de xantana (XC e XP) reduziu a firmeza e influenciou positivamente a qualidade dos bolos sem glúten. Todas as formulações com xantana XC (F1-346 g e F2-299 g) e XP (F3-350 g e F4-353 g) forneceram bolos de menor firmeza, consequentemente mais macios do que o controle $\mathrm{C} 1$ (475 g), com resultados mais próximos ao controle C2 (242 g). A adição ou tipo de xantana usada não influenciou a elasticidade das formulações (C1-59\%; F1-60\%; F2-61\%; F3-60\%; F4-60\% e C2-59\%). Preichardt et al (2011) encontraram resultados semelhantes para firmeza e elasticidade em bolos sem glúten elaborados com xantana comercial.

Dezesseis dos trinta painelistas não notaram diferença entre as amostras no teste triangular; portanto, segundo Profiqua (2000), não houve diferença significativa entre bolos feitos com $0,3 \%$ de XC e $0,3 \%$ de XP. 0 mesmo resultado para os bolos feitos com $0,4 \%$ de XC e $0,4 \%$ de XP foi obtido. Esses resultados demonstram que a xantana XP pode ser usada na produção de bolos sem glúten sem comprometer sua qualidade sensorial.

\section{CONCLUSÃO}

Apesar da xantana pruni 106 (XP) ter contribuído de forma menos intensa que a xantana comercial (XC) para o volume específico dos produtos, verificou-se sua eficiência tecnológica e adequabilidade sensorial na elaboração de bolos sem glúten, já que proporcionou características tecnológicas e sensoriais semelhantes às da xantana comercial.

\section{AGRADECIMENTOS}

Agradecemos ao CNPq pelo suporte financeiro. 


\section{REFERÊNCIAS}

[1] DANI, R. Gastroenterologia Essencial. 4 ed., Rio de Janeiro: Guanabara Koogan, 2011. 1401 p.

[2] INSTITUTO ADOLFo LUTZ. Métodos Fisíco-Químicos para Análise de Alimentos, 4ạa ed., v. 1, São Paulo: IMESP, 2004. p. 1032.

[3] MOREIRA, A. da S.; VENDRUSCOLO, J. L. S.; GIL-TURNES, C.; VENDRUSCOLO, C. T. Screening among 18 novel strains of Xanthomonas campestris pv pruni. Food Hydrocolloids, v. 15, p. 469-474, 2001. https://doi.org/10.1016/S0268-005X(01)00092-3

[4] PREICHARDT, L.D.; VENDRUSCOLO, C. T.; GULARTE, M. A.; MOREIRA, A. da S. The role of xanthan gum in the quality of gluten free cakes: improved bakery products for coeliac patients. International Journal of Food Science \& Technology, v. 46, no 12, p 2591-2597, 2011. https://ifst.onlinelibrary.wiley.com/doi/abs/10.1111/j.13652621.2011.02788.x

[5] PROFÍQUA - Associação Brasileira Dos Profissionais da Qualidade de Alimentos. (2000). Análise Sensorial Testes Discriminativos e Afetivos Manual-Série Qualidade. 1ae ed., São Paulo, p.127. 


\section{Capítulo 7}

\section{Massa de pizza low carb a base de couve-flor}

\section{Andressa Rafaella da Silva Bruni \\ Valéria Oliari Moreto \\ Aline Chiczta \\ Felipe Balicki Corrêa \\ Bruno Podolak}

Katielle Rosalva Voncik Córdova

\section{Herta Stutz}

Resumo: A dieta de baixo carboidrato (low carb) evidencia em curto prazo a perda de peso, diminuição dos níveis de triglicerídeos, aumento do HDL e, além disso, ainda traz benefícios para pacientes diabéticos. Tendo em vista esses problemas e a tendência de crescimento de produtos benéficos à saúde. 0 objetivo deste estudo foi elaborar pizza low carb semipronta à base de couve-flor e realizar análises físico-químicas, microbiológicas e sensoriais. Em substituição à farinha de trigo utilizou-se 69,22\% de couve-flor (padrão) e 66,91\% de couve-flor com 3,34\% de farinha de arroz (formulação 1). Para caracterizar a qualidade e aceitação da massa foram realizadas as análises físico-químicas, microbiológicas e sensoriais. Obtendo assim, um produto com baixa concentração de carboidratos $(7,26 \% \pm 0,47$ para a formulação padrão e $21,44 \% \pm 0,57$ para a formulação 1). Com base nos dados obtidos na análise sensorial, a pizza com baixo teor de carboidrato demonstrou ser um alimento com potencialidade de mercado e diferencial competitivo, uma vez que a maioria dos provadores consumiriam com frequência o produto, não apresentando diferença significativa $(\mathrm{p} \leq 0.05)$ entre essas. Sendo assim, a formulação padrão foi escolhida para a elaboração de um novo produto, visto todos os benefícios nutricionais que essa pode oferecer ao consumidor.

Palavras-chave: Análise Sensorial, Carboidratos, Saudabilidade. 


\section{INTRODUÇÃO}

A massa constitui uma fração significativa da pizza. A aparência, sabor e textura são fatores importantes para sua identificação e aceitação pelo consumidor. Essa massa é produzida, comumente, a partir da farinha de trigo, que possui alto valor calórico, e apresenta baixa qualidade proteica (GUZMAM, 2007).

O poder de compra da população está crescendo, e consequentemente a busca produtos saborosos, convenientes e também nutritivos. Isso acarreta a diferenciação do mercado de pizza com sabores e recheios diferenciados, novos ingredientes adicionados a massa e diferentes técnicas de preparação (CAMPELO et al., 2017), bem como a restrição de alguns nutrientes da massa, como a massa com baixo teor de carboidrato.

Designa-se como dieta com baixo teor de carboidrato (low carb) aquela que diminui a quantidade de carboidratos ingeridos. Normalmente uma alimentação convencional obtém cerca de 50 a $55 \%$ do que é consumido por dia de carboidratos, já quando se trata de low carb pode conter de 5 a $45 \%$. Em algumas revisões foram observadas perdas de peso significativas em indivíduos com sobrepeso após aderirem à dieta, quando comparadas com dietas convencionais, além disso, pode-se observar também uma menor taxa de colesterol LDL em indivíduos adeptos à dieta. Outro benefício é a melhoria nos parâmetros de insulina e glicemia em indivíduos diabéticos ou pré-diabéticos (BALDINI, 2016).

Uma vez que o termo low carb é algo recente, os produtos deste segmento ainda não possuem legislação específica. Deste modo, pode-se enquadrá-lo como um alimento para fim especial, que segundo a Portaria №29, de 13 de janeiro de 1998, são aqueles formulados ou processados de forma especial, nos quais se promovem modificações no conteúdo nutricional, adequados à utilização em dietas diferenciadas ou opcionais, atendendo às necessidades de indivíduos que se encontram em condições metabólicas e fisiológicas específicas, como dietas com restrição de carboidratos (BRASIL, 1998).

A couve-flor é considerada um alimento funcional, pois além do efeito nutricional apresenta efeito sobre as funções fisiológicas. Este vegetal possui compostos antioxidantes, como isotiacianatos, indóis e glicosilatos, que inibem a mutação do DNA, prevenindo a ocorrência de câncer (NASCIMENTO et al., 2015). Contém também glucosinolatos, compostos nitrogenados com enxofre em sua estrutura. Estes compostos são ativadores de enzimas responsáveis pela desintoxicação do fígado e, por isso, protegem o organismo contra carcinogênese e mutagênese (MITHEN et al., 2000; ANJO, 2004).

Enquanto a farinha de trigo apresenta $75,1 \%$ de carboidratos em sua composição, a couve-flor contém apenas $4,5 \%$ e, por isso, seu valor calórico é significativamente menor, $23 \mathrm{kcal}$ frente a $360 \mathrm{kcal}$ para a farinha de trigo (TACO, 2011). Com base nisso e na grande procura de produtos que sejam de rápido preparo e nutritivos, mas que ainda garantam suas características sensoriais torna-se interessante a preparação de uma massa a partir de couve-flor, promovendo a restrição de carboidratos, diminuição do valor calórico, bem como benefícios à saúde. Desta forma, a massa de pizza pode ser direcionada para consumidores adeptos de dietas low carb, celíacos, além de auxiliar no controle de doenças, como diabetes.

O intuito deste trabalho foi elaborar pizza low carb semipronta, utilizando a couve-flor como ingrediente base, e avaliar a qualidade do produto final por meio de análises físico-químicas e microbiológicas, bem como realizar a avaliação sensorial para averiguar o nível de aceitação e preferência do produto.

\section{METODOLOGIA}

\subsection{MATERIAL}

Os ingredientes utilizados na elaboração de massa pizza low carb foram adquiridos no comércio local da cidade de Guarapuava - PR.

\subsection{FORMULAÇ̃̃O DA MASSA DE PIZZA LOW CARB}

Foram elaboradas duas formulações de massa de pizza low carb, sendo uma à base somente de couve-flor (Padrão) e outra com adição de farinha de arroz (Formulação 1).

Primeiramente, a couve-flor foi selecionada, lavada, triturada e pesada. Em seguida, foram pesados os demais ingredientes em suas respectivas proporções, de acordo com a Tabela 1. 
Os ingredientes foram misturados até que a massa atingisse a consistência adequada para ser moldada. Então, as formas foram untadas e a massa de pizza depositada sobre ela. Posteriormente, a massa foi levada ao forno à temperatura de $120^{\circ} \mathrm{C}$ por aproximadamente 10 minutos para um pré-assamento.

Tabela 1 - Formulação das massas de pizza low carb.

\begin{tabular}{|l|c|c|}
\multicolumn{1}{c}{ Ingredientes } & Padrão & Formulação 1 \\
\hline Couve-flor (\%) & 69,22 & 66,91 \\
\hline Queijo parmesão (\%) & 13,84 & 13,38 \\
\hline Ovos (\%) & 16,61 & 16,06 \\
\hline Farinha de arroz (\%) & 0 & 3,34 \\
\hline Sal (\%) & 0,28 & 0,27 \\
\hline Ácido ascórbico (\%) & 0,04 & 0,04 \\
\hline
\end{tabular}

A Tabela 2 apresenta os ingredientes utilizados na formulação do recheio de frango da massa de pizza low carb.

Tabela 2 - Formulação do recheio das pizzas low carb.

\begin{tabular}{|l|c|c|}
\multicolumn{1}{c|}{ Ingredientes } & Quantidade $(\mathrm{g})$ & $\%$ \\
\hline Queijo muçarela & 10 & 43,47 \\
\hline Peito de frango desfiado temperado & 15 & 43,48 \\
\hline Molho de tomate & 10 & 10,86 \\
\hline Orégano & 0,5 & 1,09 \\
\hline Sal & 0,5 & 1,09 \\
\hline
\end{tabular}

Coccionou-se o peito de frango acrescido de sal e, em seguida, o mesmo foi desfiado e refogado com alho. Sobre a massa pré-assada adicionou-se o molho de tomate, a muçarela ralada, o peito de frango temperado e orégano. A pizza então foi colocada ao forno à $120^{\circ} \mathrm{C}$ por 15 minutos para completar o assamento. 0 peso final das mini pizzas foi de $160 \mathrm{~g}$ cada e, para a análise sensorial, cada mini pizza foi dividida em quatro partes $(40 \mathrm{~g})$.

\subsection{ANÁLISES FÍSICO-QUÍMICAS}

Foram realizadas as análises de umidade, cinzas, lipídeos, proteínas e fibra bruta do produto final de acordo com as metodologias do Instituto Adolfo Lutz (IAL, 2008). Os carboidratos foram determinados por diferença dos demais componentes. As análises foram realizadas em triplicata no produto final, constituído da massa mais o recheio.

\subsection{ANÁLISE SENSORIAL}

Esta pesquisa teve seu projeto aprovado pelo Comitê de Ética em Pesquisa da Universidade Estadual do Centro-Oeste - UNICENTRO/PR, no parecer número 2.678.472.

Os testes sensoriais foram conduzidos em cabines individuais, com cinquenta avaliadores não treinados de ambos os sexos, com faixa etária de 17 a 35 anos, integrantes do Departamento de Engenharia de Alimentos da Universidade Estadual do Centro-Oeste. Estes receberam duas amostras codificadas com três dígitos (obtidos por meio de tabela de número aleatórios - random orders) de forma casualizada, sendo uma amostra contendo farinha de arroz na massa (Formulação 1) e outra isenta deste ingrediente (Padrão), acompanhadas de um copo de água mineral. Juntamente com o Termo de Consentimento Livre e Esclarecido para a participação e a Ficha de Avaliação das amostras. Foram realizados os testes de perfil de característica em relação aos atributos cor, aroma, textura, aparência, utilizando o escore de 1 (péssimo) a 5 (excelente), aceitação, utilizando uma escala hedônica, variando de 1 (desgostei muitíssimo) a 9 (gostei muitíssimo) e intenção de compra utilizando uma escala que vai de 1 (nunca comeria) a 7 (comeria sempre) (DUTCOSKY, 2011). 
Os resultados das análises foram analisados estatisticamente por meio da Análise de Variância e Teste tStudent ao nível de 5\% de significância, como objetivo de verificar possíveis diferenças entre as amostras.

\subsection{ANÁLISES MICROBIOLÓGICAS}

Foram realizadas as análises de Coliformes a $45{ }^{\circ} \mathrm{C}$, Estafilococos coagulase positiva, Bacillus Cereus e Salmonella sp. no produto final, constituído da massa mais o recheio, de acordo com as metodologias descritas por Silva, Junqueira e Silveira (1997).

\section{RESULTADOS E DISCUSSÃO}

A tabela 3 apresenta a composição físico-química em $100 \mathrm{~g}$ da pizza padrão, à base somente de couve-flor, e da formulação 1, acrescida de farinha de arroz. Verificou-se que as formulações diferiram significativamente em todos os parâmetros analisados, onde a formulação padrão apresentou valores maiores para todos os componentes, com exceção dos carboidratos. Com relação ao teor de proteína, com base nos valores diários recomendados em uma dieta de $2000 \mathrm{kcal}$, a formulação padrão atingiu aproximadamente 56\% VD e a formulação 147 \%VD. Segundo a Portaria no 27, de 13 de janeiro de 1998, que aprova o Regulamento Técnico referente à Informação Nutricional Complementar, um produto é considerado fonte de proteína se tiver, no mínimo, 10\% da porcentagem de VD (100 g de produto). Portanto, tanto a formulação padrão quanto a Formulação 1 podem ser consideradas boas fontes proteicas.

Tabela 3 - Composição centesimal, em base seca, das massas de pizza padrão(1)e da formulação $1^{(2)}$

\begin{tabular}{|c|c|c|}
\hline Componente* & Padrão & Formulação 1 \\
\hline Cinzas (g.100g-1) & $8,71^{a} \pm 0,21$ & $7,44 \mathrm{~b} \pm 0,17$ \\
\hline Lipídeos (g.100g-1) & $29,38^{a} \pm 0,69$ & $25,80^{\mathrm{b}} \pm 0,46$ \\
\hline Proteínas (g.100g-1) & $42,23^{\mathrm{a}} \pm 0,94$ & $35,53^{b} \pm 0,33$ \\
\hline Fibra Bruta (g.100g-1) & $12,42^{a} \pm 0,43$ & $9,80^{\mathrm{b}} \pm 0,55$ \\
\hline Carboidratos (g.100g-1) & $7,26^{a} \pm 0,47$ & $21,44^{b} \pm 0,57$ \\
\hline
\end{tabular}

(1) massa de pizza sem adição de farinha de arroz; (2) massa de pizza com adição de farinha de arroz; *Média de triplicatas \pm desvio padrão; médias seguidas pela mesma letra na linha não diferem entre si pelo teste t-Student a $5 \%$ de probabilidade.

No que se refere aos valores de fibra bruta, a formulação padrão apresentou maior quantidade que a formulação 1, 12,42 e 9,80 g.100g-1 , respectivamente. Moreto et al. (2017), ao avaliar a composição centesimal de massa de pizza acrescida de farinha de batata doce, obteve 1,63\% de fibra bruta em uma massa de pizza com substituição de $25 \%$ de farinha de trigo por farinha de batata doce, enquanto a formulação controle, sem adição de farinha de batata doce, apresentou apenas 0,47\% de fibra bruta, em base seca. Com base nisso, ambas as formulações de pizza low carb podem ser consideradas fontes interessantes de fibra bruta, acarretando benefícios à saúde do consumidor, como o aumento dos movimentos peristálticos intestinais, diminuição da absorção de gorduras, produção de ácidos graxos de cadeia curta que auxiliam no combate ao colesterol, além de proporcionar elevado poder de saciedade (LIMA et al., 2004).

Os teores de carboidratos obtidos na formulação padrão e 1 foram 7,26 e 21,44\%, respectivamente. Esses teores são menores que os encontrados por Oliveira, Pirozi e Borges (2007) para pão de sal com substituição de $10 \%$ de farinha de trigo por farinha de linhaça $(81,21 \%$ b.s.) e para o pão controle, sem adição de farinha de linhaça (68,96\% b.s.). Desta forma, a formulação padrão de pizza low carb, apresenta uma quantidade baixa e muito interessante de carboidratos, especialmente àqueles adeptos de dietas com restrição ou redução de carboidratos, como a dieta low carb, ou ainda, a pessoas intolerantes ao glúten.

A tabela 4 contempla os dados da análise sensorial em média e desvio padrão, referente a aparência, aroma, sabor residual, textura e cor da pizza low carb a base de couve-flor (padrão) e com adição de farinha de arroz (formulação 1), respectivamente. 
Tabela 4 - Médias das notas atribuídas pelos provadores para o teste de perfil de característica das formulações de massa de pizza low carb.

\begin{tabular}{|l|c|c|c|c|c|}
\multicolumn{1}{|c}{ Formulação } & Aparência & \multicolumn{2}{c|}{ Aroma } & \multicolumn{2}{c|}{ Textura } \\
\hline Padrão & $4,60^{\mathrm{a}} \pm 0,58$ & $4,42^{\mathrm{a}} \pm 0,64$ & $4,16^{\mathrm{a}} \pm 0,89$ & $4,22^{\mathrm{a}} \pm 0,84$ & $4,72^{\mathrm{a}} \pm 0,54$ \\
\hline Formulação 1 & $4,60^{\mathrm{a}} \pm 0,57$ & $4,56^{\mathrm{a}} \pm 0,70$ & $4,28^{\mathrm{a}} \pm 0,93$ & $4,46^{\mathrm{a}} \pm 0,68$ & $4,70^{\mathrm{a}} \pm 0,51$ \\
\hline
\end{tabular}

*Média de 50 replicatas \pm desvio padrão; médias seguidas pela mesma letra na coluna não diferem entre si pelo teste t-Student a 5\% de probabilidade.

De acordo com os dados apresentados na Tabela 4, pode se observar que em nenhum dos atributos houve diferença significativa entre a formulação padrão e a formulação 1 . ( $\mathrm{p} \leq 0.05)$. Levando em consideração que o escore era 1 para péssimo e 5 para excelente, todos os quesitos obtiveram médias acima de 4 , evidenciando que todas as características sensoriais da massa de pizza low carb foram bem apreciada pelos julgadores.

Farias (2009) realizou análise sensorial de massas de pizza a partir de farinha de arroz refinada, farinha de arroz flocada, arroz polido e farinha de trigo e observou que as três formulações sem glúten obtiveram boa aceitabilidade, se tornando mais uma opção aos celíacos. No qual, nenhuma das variáveis: aparência, aroma, sabor e impressão global se diferiram significativamente, podendo ser uma alternativa ao uso da farinha de trigo. Outro estudo feito por Vilela et. al. (2016) analisou sensorialmente uma massa de pizza com farinha de arroz e grão de bico, no qual, comparada com a massa de farinha de trigo, a outra obteve uma maior elasticidade e melhor consistência, podendo ser também de grande interesse aos intolerantes ao glúten.

Na tabela 5 encontram-se os valores de média e desvio padrão sobre a aceitação global e intenção de compra dos julgadores sobre a pizza low carb.

Com relação à aceitação, observa-se que as formulações também não diferiram significativamente, sendo que a massa de pizza low carb com adição de farinha de arroz obteve uma média ligeiramente maior. Visto que as médias variavam de 1 (desgostei muitíssimo) e 9 (gostei muitíssimo), as notas ficaram entre 7 e 8 que corresponde a gostei moderadamente e gostei muito, respectivamente, sendo assim, as massas foram aprovadas pelo paladar dos julgadores.

Tabela 5 - Médias das notas atribuídas pelos provadores para a aceitação global e intenção de compra das formulações de massa de pizza low carb.

\begin{tabular}{|c|c|c|}
\hline Formulação & Aceitação Global & Intenção de Compra \\
\hline Padrão & $7,60^{a} \pm 1,28$ & $5,30^{a} \pm 1,25$ \\
\hline Formulação 1 & $7,78^{\mathrm{a}} \pm 1,23$ & $5,52^{\mathrm{a}} \pm 1,40$ \\
\hline
\end{tabular}

*Média de 50 replicatas \pm desvio padrão; médias seguidas pela mesma letra na coluna não diferem entre si pelo teste t-Student a 5\% de probabilidade.

Em relação à intenção de compra, que varia de 1 (nunca comeria) a 7 (sempre comeria), as amostras também não diferiram, permanecendo com notas próximas a 5 que se refere a comeria frequentemente, evidenciando que se a massa de pizza low carb fosse comercializada teria uma boa saída de mercado.

Visto que a formulação padrão, ou seja, só a base de couve-flor, obteve aceitação similar a formulação 1 , essa será a escolhida na elaboração de um novo produto, uma vez que a couve-flor possui uma grande quantidade de nutrientes como vitamina C, manganês, vitaminas B5 e B6, ajuda na perda de peso, sensação de saciedade devido às suas fibras e a prevenção contra o câncer. E ainda, sem a adição da farinha de arroz, há uma diminuição ainda maior na quantidade de carboidratos.

Na tabela 6 é possível observar as principais análises microbiológicas contidas na legislação referentes a massas frescas ou pré-assadas. Os resultados obtidos foram condizentes com a legislação brasileira e, por isso, a massa é considerada, segura para o consumo. 
Tabela 6- Resultados referentes às análises microbiológicas das pizzas low carb.

\begin{tabular}{|l|c|c|c|}
\multicolumn{1}{c}{ Análise } & Formulação padrão & Formulação 1 & Referência \\
\hline Coliformes fecais & $<0.03 / \mathrm{g}$ & $<0.03 / \mathrm{g}$ & $5.10^{2} / \mathrm{g}$ \\
\hline Salmonella sp. & Ausência/25g & Ausência $/ 25 \mathrm{~g}$ & Ausência/25g \\
\hline Bacillus cereus & $2.10^{2}$ & $5.10^{2}$ & $5.10^{3}$ \\
\hline Estaf. Coag. positiva & $\mathrm{X}$ & $\mathrm{X}$ & $5.10^{3}$ \\
\hline
\end{tabular}

Para os Coliformes Fecais foi possível observar apenas em um dos tubos o desenvolvimento de gás. De acordo com o número mais provável (Bacteriological Analytical Manual 6 ed.), pode-se chegar a um resultado baixo, o qual resulta na quase ausência desse tipo de microrganismo.

A Salmonela sp. é um dos principais microrganismos envolvidos em infecções causados por alimentos, daí a importância de não possuir esse tipo de microrganismos envolvido em qualquer tipo de alimento. Para a Salmonela sp., utilizando um esquema geral para detecção, (UBOLDI, 1982) obteve-se a ausência do microrganismo em 25 gramas de amostra. 0 resultado obtido também condiz com a legislação brasileira.

No caso dos Bacillus cereus, eles podem estar envolvidos em intoxicações alimentares, desde que ingeridos em grande quantidade. Para isso, a legislação brasileira estipula um limite de $5.10^{3}$ microrganismos por grama de amostra. Nesse casso foi possível detectar uma quantidade bem menor, portanto, está de acordo com a legislação.

A análise de estafililococcos coagulase positiva indica a presença de bactérias nocivas a saúde, cuja doença transmitida por alimentos é uma intoxicação, provocada pela ingestão de toxinas formadas no alimento, quando ocorre a multiplicação das células. Nesse caso, devido à falta de material para as análises, não foi possível avaliar o alimento.

\section{CONCLUSÕES}

A introdução de produtos low carb na dieta da população é de extremo benefício, uma vez que é eficiente para a perda de peso, diminuição dos níveis de triglicerídeos e aumento do HDL. Observou-se que as duas amostras de pizza low carb apresentaram valores interessantes de composição centesimal e boa aceitação pela equipe de provadores, demonstrando ser um alimento com potencialidade de mercado e diferencial competitivo. Como não houve diferença significativa entre as amostras, a escolhida para a comercialização foi a padrão, como base apenas a couve flor, pois sem a adição da farinha de arroz há uma diminuição ainda maior na quantidade de carboidratos.

\section{REFERÊNCIAS}

[1] ALVAREZ M. La cocina como patrimonio (in)tangible. In: Maronese I. organizador. Primeras jornadas de patrimonio gastronomico. CPPHC-CABA: Buenos Aires; 2002. p. 3-15.

[2] ANJO, D. F. C. Alimentos funcionais em angiologia e cirurgia vascular. J. Vasc. Br., v. 3, n. 2, p.145-154, 2004.

[3] BALDINI, M. CRN, Conselho Regional de Nutricionistas 3ํo Região SP/MS. Evidências científicas da dieta low carb da dieta cetogênica, $2016 . \quad$ Disponível <http://www.crn3.org.br/Areas/Admin/Content/upload/revista/pdfs/Revista_CRN_ED_17_WEB.pdf>. Acesso em: 14 de março de 2018.

[4] BRASIL. Ministério da Saúde. Agência Nacional de Vigilância Sanitária. Portaria no 29, de 13 de janeiro de 1998. Regulamento Técnico referente a Alimentos para Fins Especiais. Diário Oficial da União, Brasília, DF, 30 mar. 1998.

[5] BRASIL. Ministério da saúde. Secretaria de vigilância em Saúde. Vigitel Brasil, 2016: Vigilância de fatores de risco e proteção para doenças crônicas por inquérito telefônico. Brasília: Ministério da Saúde, 2016. p.44. Disponível em: <https://www.endocrino.org.br/media/uploads/PDFs/vigitel.pdf>. Acesso em:02 de abr. 2018.

[6] BRASIL. Ministério da Saúde. Portaria no 27, de 13 de janeiro de 1998. Aprova o regulamento técnico à informação nutricional complementar. Diário Oficial da União. Brasil, Brasília, DF, jan. 1998

[7] CAMPELO, D.A.V.; SOUZA, M.L.R.; MOURA, L.B.; XAVIER, T.O.; YOSHIDA, G.M.; REIS, E.S. MIKCHA, J.M.G. Addition of different tuna meal levels to pizza dough. Braz. J. Food Technol., v.20, e2016014, p.1-8, 2017.

[8] DUTCOSKY, S. D. Análise Sensorial de Alimentos. Curitiba: 3ํㅗed. Ed. Universitária Champagnat, 426 p, 2011 
[9] FARIAS, A.S. Massas para pizza com restrição ao glúten. 2009. 42 f. Dissertação (Monografia apresentada ao Centro de Excelência em Turismo CET como requisito parcial à obtenção do grau de Especialista em Qualidade de Alimentos) - Universidade de Brasília, Brasília, 2009.

[10] GUZMAM, G.J.; MURPHY, P.A.; JOHNSON, L.A. Properties of soybean-corn mixtures processed by low-cost extrusion. J. Food Sci, v.54, p.1590-1593, 2007.

[11] INSTITUTO ADOLFO LUTZ - IAL. Normas Analíticas do Instituto Adolfo Lutz. 3. ed. São Paulo: IMESP, v. 1: Métodos físicos e químicos para análise de alimentos. p. 1020, 2008.

[12] LIMA, S.C.V.C.; ARRAIS, R.F.; PEDROSA, L.F.C. Avaliação da dieta habitual de crianças e adolescentes com sobrepeso e obesidade. Revista de Nutrição, Campinas, v.17, n.4, p.469-477, 2004.

[13] MACHADO, R. L. P. Manual de rotulagem de alimentos. Rio de Janeiro: Embrapa Agroindústria de Alimentos, 2015. 24 p. - (Documentos / Embrapa Agroindústria de Alimentos, ISSN 1516-8247).

[14] MITHEN, R. F.; DEKKER, M.; VERKERK, R.; RABOT, S.; JOHSON, I. T. The nutricional significance and bioavailability of glucosinolates in human foods rewiew. J. Sci Food Agric., v.80, p.967-984, 2000.

[15] MORETO, V. O.; CZAIKOSKI, K.; MICHELETTI, I. N.; KEIBER, M. Desenvolvimento e caracterização química de massa de pizza acrescida de farinha de batata doce. In: V SIEPE, 2017, Guarapuava. Anais... . Guarapuava: Unicentro, 2017.

[16] NASCIMENTO, F. S. M.; GÓIS, D. N. S.; ALMEIDA, D. S.; NASCIMENTO, A. L.; ALMEIDA, T. C.; GUEDES, V. R. A importância do acompanhamento nutricional no tratamento e na prevenção do câncer. Ciências Biológicas e de Saúde Unit, Aracaju, v. 2, n. 3, p.11-24, mar. 2015.

[17] OLIVEIRA, T. M.; PIROZI, M. R.; BORGES, J. T. S. Elaboração de pão de sal utilizando farinha mista de trigo e linhaça. Alim. Nutr., Araraquara, v.18, n.2, p. 141-150, abr./jun. 2007.

[18] SILVA, N.; JUNQUEIRA, V. C. A.; SILVEIRA, N. F. A.. Manual de métodos de análise microbiológica de alimentos. São Paulo: Livraria Varela, 1997, p. 83-121.

[19] TABELA BRASILEIRA DE COMPOSIÇÃO DE ALIMENTOS - TACO. 4a ed. UNICAMP, 2011. Disponível em: < http://www.nepa.unicamp.br/taco/tabela.php?ativo=tabela >. Acesso em: 10 abr. 2018.

[20] VILELA, J.; BASTOS, P.; LIMA, C.M.; GONÇALVEZ, A.; SANTOS, A. Elaboração e aceitabilidade de pizza com farinha de arroz e grão de bico. 2016. 2f. Dissertação (Artigo apresentado ao curso de Nutrição e Gastronomia) Faculdade de Ciências da Educação e Saúde (FACES), Centro Universitário de Brasília (UNCEUB), Brasília, 2016. 


\section{Capítulo 8}

Produção de exopolissacarídeos por Lentinula edodes e Ganoderma lucidium em diferentes néctares de frutas

\section{Kennidy de Bortoli}

Daiane Cristina Lenhard

Resumo: Cogumelos comestíveis são conhecidos por seu sabor característico, e principalmente por conterem e produzirem compostos com características funcionais comprovadas. Neste trabalho, Ganoderma lucidium e Lentinula edodes foram desenvolvidos em cultivo submerso, com a utilização de diferentes néctares de frutas como substrato de crescimento micelial e produção de exopolissacarídeos (EPSs). Cepas isoladas foram adicionadas aos néctares de frutas e submetidos a uma incubação de quatorze dias a temperatura controlada $\left(20^{\circ} \mathrm{C}\right)$. Para o G. lucidium verificou-se máxima produção de EPSs e biomassa de 0,3063 \pm 0,0444 g.L-1 e 2,2912 \pm 0,4769 g.L-1, respectivamente, enquanto para o L. edodes foram verificadas produções de 0,2570 \pm 0,0447 g.L-1 e 2,0415 \pm 0,5394 g.L-1 de EPSs e biomassa, respectivamente. Com os resultados obtidos nesse trabalho, observa-se uma possível aplicação industrial, visando a proposta de um produto com características positivas em relação à saúde.

Palavras-Chave: Cogumelos, biomassa fúngica, EPS, substrato de frutas. 


\section{INTRODUÇ̃̃O}

Os cogumelos são alimentos muito apreciados desde a idade antiga, onde acreditava-se em seu elevado valor nutritivo e em seu potencial medicinal. São conhecidas aproximadamente 2000 espécies comestíveis (URBEN et al., 2001). Dentre essas, existem três espécies mais comumente cultivadas e consumidas no Brasil: A. Bisporus conhecido popularmente como champignon de Paris; L. edodes, como Shiitake; e Pleurotus sp. conhecido como shimeji (URBEN et al., 2001). Os cogumelos champignon, shiitake e shimeji, por sua composição química, constituem um alimento com excelente valor nutritivo pois apresentam alto teor de proteínas, fibras alimentares, baixo teor de lipídeos, além de uma considerável quantidade de fósforo (FURLANI, GODOY, 2007).

Esses cogumelos possuem a capacidade de produzir uma grande variedade de metabólitos secundários com alto valor terapêutico (DEMAIN, 1999) e propriedades benéficas á saúde, tais como antioxidantes, antimicrobianas, anticancerígenas, redutoras de colesterol e com efeitos imunoestimuladores (MIZUNO, 1999). Estes compostos estão presentes tanto no corpo de frutificação quanto no micélio (FERREIRA et al., 2007).

Várias espécies de cogumelos têm sido apontadas como fontes de compostos antioxidantes, como por exemplo Lactarius deliciosus e Tricholoma portentosum investigados por FERREIRA et al. (2007).

O L. edodes tem recebido grande atenção devido aos efeitos positivos para a saúde, incluindo anticarcinogênico e também por sua atividade hipocolesterolêmica (KITZBERGER et al., 2007), que estão relacionadas à presença de $\beta$-glucanas (MINATO et al., 1999).

$\beta$-Glucanas são componentes principais da parede celular estrutural de fungos, também estão presentes nos metabolismos extracelulares dos mesmos e são classificadas como Exopolissacarídeos (EPSs) (MURPHY, et al., 2010; TANAKA et al., 2011). Os EPSs são polissacarídeos lineares, não ramificados, compostos por unidades de glicose ( $\beta$-D-glicopiranosil) unidos por ligações glicosídicas $\beta-1,4$ e $\beta-1,3$. A estrutura resultante é um polissacarídeo composto principalmente de unidades $\beta-1,3$ (BROWN, GORDON, 2002; WOOD et al., 1994).

Esses polissacarídeos são bem conhecidos por serem modificadores da resposta biológica (BRMs), os quais estimulam o sistema imunológico através da ativação de várias células responsáveis pela defesa do nosso organismo, incluindo macrófagos, células dendríticas, neutrófilos e linfócitos. (SAKAMOTO et al., 2002). Nos fungos, os EPSs constituem uma importante percentagem da biomassa, englobando mais de $75 \%$ dos polissacarídeos constituintes da parede da hifa (GUTIÉRREZ et al., 1996).

Ganoderma lucidum é o cogumelo medicinal mais vendido no mundo, movimentando bilhões de dólares ao ano (URBEN, 2004). É utilizado pelos chineses há milênios devido às inúmeras propriedades terapêuticas atribuídas a esse fungo, sem nenhum efeito colateral constatado, o que despertou o interesse pelos ocidentais nas últimas décadas (RUBEL, 2006). Destacam-se sua ação antialérgica comprovada cientificamente, hipotensiva, hipoglicêmica, antibacteriana e antioxidante, também utilizado para enfermidades como hepatite, hipertensão, diabetes, úlceras e câncer gástrico (URBEN, 2004). Entre os diversos metabólitos de G. lucidum, os polissacarídeos e triterpenos são importantes princípios ativos responsáveis por suas atividades farmacológicas (RUBEL, 2006).

Devido ao grande tempo e espaço necessário para o desenvolvimento do basidiomiceto, há um recente interesse na produção de micélio em fermentação submersa, que ocupa espaços reduzidos, menos custos e diminuição das chances de contaminação, o que possibilita uma total recuperação de várias substâncias como os endopolissacarídeos, isolados do micélio, e dos exopolissacarideos, isolados do caldo de cultivo, que são biomoléculas de grande interesse farmacológico (RUBEL, 2006).

0 cultivo por fermentação submersa apresenta altas taxas de produção de glucanas extracelulares que são os homopolissacarídeos mais comuns em basidiomicetos, podendo ser lineares ou ramificadas, e apresentarem diferentes configurações e massas molares (ZHANG et al., 2007). Este procedimento também tem sido bastante utilizado para a produção de EPSs, pelo baixo custo e elevada taxa de produtividade, permitindo ainda uma produção maciça utilizando um pequeno espaço (J00 et al., 2004)

Diante do exposto, este trabalho teve como objetivo a avaliação do crescimento micelial e da produção de EPSs pelos cogumelos Ganoderma lucidium e Lentinula edodes em cultivo submerso, utilizando diferentes néctares de frutas como substrato. 


\section{MATERIAL E MÉTODOS}

\subsection{MEIOS DE CULTURA E PREPARO DE INÓCULO}

Colônias isoladas de Lentinula edodes e Ganoderma lucidium foram cedidas pelo Departamento de Biologia da Universidade Estadual de Maringá.

Para o preparo do inóculo sólido, o isolado foi cultivado em placas de Petri por meio de repicagem simples em meio de cultura agar dextrose batata (DBA), e posteriormente incubado por 7-10 dias a $20{ }^{\circ}$ C. Após o período de incubação, foram selecionadas três placas contendo os inóculos dos fungos que apresentavam colonização mais uniforme em toda a placa. A partir dessas placas, foram retiradas circunferências do fungo de $1 \mathrm{~cm}$ de diâmetro para inoculação em meio líquido.

0 meio de cultura líquido consistiu em 2,0 g.L $\mathrm{L}^{-1}$ de extrato de malte, $0,1 \mathrm{~g}$.L $\mathrm{L}^{-1}$ de peptona e 2,0 g.L $\mathrm{L}^{-1}$ de glicose. Foram preparados tubos e ensaio com $10 \mathrm{~mL}$ deste meio de cultura aos quais foram adicionadas duas circunferências de inóculo sólido dos fungos. Após a inoculação, as amostras forma incubadas por 14 dias à $20^{\circ} \mathrm{C}$ para crescimento do micélio fúngico.

Após o período de incubação, antes de serem utilizados como inóculo para o crescimento nos néctares de frutas, os tubos de ensaio foram agitados para homogeneização do micélio no meio líquido.

\subsection{ENSAIOS DE CRESCIMENTO DOS FUNGOS EM NÉCTARES DE FRUTAS}

Como substrato líquido para desenvolvimento do fungo, foram utilizados cinco tipos diferentes de néctar de fruta industrializados (laranja, maracujá, uva, pêssego e abacaxi), da marca "SU FRESH ${ }^{\circledR}$ ". Para os ensaios, $50 \mathrm{~mL}$ de cada néctar foram colocados em frascos e autoclavados.

Ao néctar autoclavado foi adicionado o inóculo de fungo preparado em meio líquido, na proporção de 10 $\mathrm{mL}$ para $50 \mathrm{~mL}$ de néctar. Após a inoculação os frascos foram incubados por 14 dias a $20^{\circ} \mathrm{C}$. Todos os ensaios foram realizados em quintuplicata.

\subsection{ANÁLISES REALIZADAS}

Para a determinação do crescimento da biomassa, foi realizada uma análise gravimétrica, consistindo de filtragem simples, seguida de secagem e pesagem da biomassa.

A determinação de presença e quantificação de EPS foi realizada por precipitação com utilização de álcool etílico 99\%, utilizando a proporção 1:1 v/v, seguida de filtragem, secagem e pesagem do precipitado, de acordo com a metodologia utilizada por ZHANG et al. (2006).

Para cada ensaio foi determinado o pH do néctar, utilizando um pHmetro digital de bancada, da marca Hanna ${ }^{\circledR}$.

\section{RESULTADO E DISCUSSÃO}

Os resultados referentes à produção de EPSs e de biomassa, pelos fungos G. Lucidium e L. edodes, estão apresentados nas tabelas 1 e 2, respectivamente. A produção de EPSs e de biomassa refere-se à quantidade (em gramas) obtida em cada $50 \mathrm{~mL}$ de substrato utilizado nos ensaios.

Verifica-se que a máxima produção de EPSs por L. edodes ocorreu para o suco com maior valor pH $(3,71)$, porém, o mesmo não ocorre ao se utilizar a cepa de G. lucidium, verficando-se a maior produção de EPSs utilizando-se o substrato de maracujá, com o pH de 3,2. Lee et al. (1999) verificaram que o pH influencia muito a produção de EPSs no cultivo submerso de G. lucidum. Eles definiram uma técnica onde é mantido na fase inicial do cultivo um $\mathrm{pH}=3$ e foi aumentado exponencialmente até 6,0 no final do cultivo, o que aumentou a produção de EPS de 2,1 g.L-1 para 4,1 g.L-1 além de promover baixa viscosidade e elasticidade do meio de cultura. Isso se deve porque o pH próximo a 6,0 promove a produção de EPSs. 
Tabela 1 - Produção de EPSs por G. Lucidium e L. edodes

\begin{tabular}{|c|c|c|c|}
\hline Amostras & $\mathrm{pH}$ & $\begin{array}{l}\text { Produção de EPS (g) } \\
\text { por G. lucidium }(*)\end{array}$ & $\begin{array}{c}\text { Produção de EPS (g) por } L . \\
\text { edodes }(*)\end{array}$ \\
\hline Maracujá & 3,20 & $0,31 \pm 0,101^{a}$ & $0,24 \pm 0,046^{a}$ \\
\hline Pêssego & 3,71 & $0,22 \pm 0,044^{a, b, c}$ & $0,26 \pm 0,045^{a}$ \\
\hline Uva & 2,80 & $0,20 \pm 0,0337 \mathrm{c}$ & $0,19 \pm 0,025^{b}$ \\
\hline Abacaxi & 4,20 & $0,27 \pm 0,0432^{a}$ & $0,23 \pm 0,056^{a, b}$ \\
\hline Laranja & 3,55 & $0,28 \pm 0,040^{a, b}$ & $0,20 \pm 0,051^{a, b}$ \\
\hline
\end{tabular}

${ }^{*}$ ) As médias em uma mesma linha vertical contendo a mesma letra não diferem entre si ao nível de $95 \%$ de confiabilidade.

RUBEL (2006) relatou que altas concentrações iniciais de glicose e também de sacarose em meio de cultura submerso, aumentam a produção de EPSs de G. lucidum, mas diminuíram drasticamente a produção de biomassa. Segundo os autores, a alta osmolaridade do meio é um fator de estresse para as células, levando à inibição do crescimento celular e a aumento na produção de polissacarídeo, como forma de defesa. Esse fato, juntamente com o pH, pode explicar a maior produção de EPSs no néctar de maracujá, o qual apresentava uma quantidade maior de sacarose, presente nas formulações estudadas para a linhagem de G. lucidium.

Tabela 2 - Produção de biomassa por G. Lucidium e L. edodes

\begin{tabular}{|c|c|c|c|}
\hline Amostras & $\mathrm{pH}$ & $\begin{array}{l}\text { Produção de biomassa (g) } \\
\text { por G. lucidium }\left(^{*}\right)\end{array}$ & $\begin{array}{c}\text { Produção de } \\
\text { biomassa (g) por } L . \\
\text { edodes(*) }\end{array}$ \\
\hline Maracujá & 3,20 & $0,99 \pm 0,477 \mathrm{~b}$ & $1,24 \pm 0,212^{\mathrm{b}}$ \\
\hline Pêssego & 3,71 & $2,29 \pm 0,326^{a}$ & $2,04 \pm 0,539 a$ \\
\hline Uva & 2,80 & $0,83 \pm 0,038^{b}$ & $0,59 \pm 0,098^{c}$ \\
\hline Abacaxi & 4,20 & $1,06 \pm 0,208^{b}$ & $1,06 \pm 0,312^{b}$ \\
\hline Laranja & 3,55 & $0,47 \pm 0,125^{c}$ & $1,28 \pm 0,538^{b}$ \\
\hline
\end{tabular}

${ }^{*}$ ) As médias em uma mesma linha vertical contendo a mesma letra não diferem entre si ao nível de $95 \%$ de confiabilidade.

Observa-se que, as maiores produções de biomassa foram obtidas nas amostras que apresentaram o maior valor de pH $(3,71)$, representado pelo néctar de pêssego, verificando-se um valor máximo de 2,0415 \pm 0,5394 g de biomassa para o substrato contendo a cepa de L. edodes e 2,2912 $\pm 0,4769 \mathrm{~g}$ de biomassa para a cepa de G. lucidium. Esse resultado corrobora o trabalho de Lee et al. (1999), em que os autores verificaram que o $\mathrm{pH}$ definitivamente afeta o crescimento micelial no cultivo submerso de G. lucidum, onde o pH próximo a 3 favorece o desenvolvimento de biomassa.

\section{CONCLUSÃO}

Os resultados obtidos neste trabalho podem ser considerados positivos para os objetivos apresentados, no que diz respeito ao desenvolvimento da biomassa e a produção de EPSs, utilizando néctares de frutas como meio de cultivo para as cepas de L. edodes e G. lucidium.

Para trabalhos futuros pretende-se um estudo mais aprofundado nas características dos meios de cultura e condições ótimas de desenvolvimento das cepas. Sugere-se avaliar maneiras de indução de produção de EPSs pelos basidiomicetos utilizados, como por exemplo, otimização do pH para crescimento micelial ou para produção de EPSs, velocidade de agitação e aeração do substrato, quantidade de carboidratos e suas respectivas fontes utilizadas no meio de cultura, dentre outras variáveis importantes de processo para o cultivo submerso. 


\section{REFERÊNCIAS}

[1] BROWN G, GORDON S. Immune recognition of fungal b-glucans. Cell. Microbiol. v.7, p. 471-479, 2005.

[2] DEMAIN, A.L. Pharmaceutically active secondary metabolites of microorganism. Appl. Microbiol. Biotechnol., v.52, p. 455-463, 1999.

[3] FERREIRA, I.C.F.R.; BAPTISTA, P.; VILAS-BOAS, M.; BARROS, L. Free-radical scavenging capacity and reducing power of wild edible mushrooms from northeast Portugal: individual cap and stipe activity. Food Chem.; v.100, p. 1511-1516, 2007.

[4] FURLANI R.P., GODOY H.T. Valor nutricional de cogumelos comestíveis. Ciênc. Tecnol. Aliment. v.27, p. 154$157,2007$.

[5] GUTIÉRREZ A.; PIETRO A.; MARTÍNEZ, A. T. Structural characterization of extracellular polysaccharides produced by fungi from the genus Pleurotus. Carbohydr. Res. v.281, p.143-154, 1996.

[6] ISAKA M., TANTICHAREON M., KONGSAEREE P., THEBTARANONTH Y. Structures of Cordypyridones A-D, Antimalarial N-Hydroxy- and N-Methoxy-2-pyridones from the Insect Pathogenic Fungus Cordyceps nipponica. $J$. Organic Chem. v.66, p. 4803-4808, 2001.

[7] JOO, J. H.; et al. Optimization of submerged culture conditions for exopolysaccharide production in Sarcodon aspratus (Berk). World J. of Microbiol. \& Biotechnol. v 20, p. 767-773, 2004.

[8] KITZBERGER C.S.G. JR., PEDROSA R.C., FERREIRA S.R.S. Antioxidant and antimicrobial activities of shiitake (Lentinula edodes) extracts obtained by organic solvents and supercritical fluids. J. Food Eng. v.80, p. 631-638, 2007.

[9] LEE, Kyu Min; LEE, Shin Young; LEE, Hyeon Yong. Bistage control of pH for improving exopolysaccharide production from mycelia of Ganoderma lucidum in an air-lift fermentor. J. Biosc. Bioeng. v. 88, p. 646-650, 1999.

[10] LOVY, A.; KNOWLES, B.; LABBE, R.; NOLAN, L. Activity of Edible Mushrooms Against the Growth of Human T4 Leukemic Cancer Cells, HeLa Cervical Cancer Cells, and Plasmodium falciparum. J. Herbs, Spices Med. Plants. v.6, p. 49$57,1999$.

[11] MINATO K., MIZUNO M., TERAI H., TSUCHIDA H. Autolysis of lentinan, an antitumor polysaccharide, during storage of Lentinus edodes, shiitake mushroom. J. Agric. Food Chem. v.47, p. 1530-1532, 1999.

[12] MIZUNO T. The extraction and development of antitumor active polysaccharides from medicinal mushrooms in Japan- Review. Inter. J. Med. mushrooms. v. 1, p. 9-30, 1999.

[13] MURPHY E.A.; DAVIS J.M.; CARMICHAEL, M.D. Immune modulating effects of B-glucan. Curr. Opi.Clin. Nutr. Metab. Care. v. 13, p. 656-661, 2010.

[14] RUBEL, Rosália. Produção de compostos bioativos de Ganoderma lucidum por fermentação em estado sólido: avaliação da ação antitumoral, imunomoduladora e hipolipidêmica. Tese (Doutorado em Processos Biotecnológicos). Setor de Tecnologia. Universidade Federal do Paraná. Curitiba, 2006.

[15] SAKAMOTO, J.; TERAMUKAI, S.; NAKAZATO, H.; SATO, Y.; UCHINO, J.; TAGUCHI, T. Efficacy of adjuvant immunochemotherapy with OK- 432 for patients with curatively resected gastric cancer : A metaanalysis of centrally randamized controlled clinical rials. J. Immunother. v.25, p. 405-412, 2002.

[16] SUTHERLAND, J. W. Novel and established applications of microbial polysaccharides. Trends in Biotechnol. v.16, p.41-46, 1998.

[17] TANAKA, K.; TANAKA, Y.; SUZUKI, T.; MIZUSHIMA, T. Protective effect of -(1,31,6)-D-glucan against irritantinduced gastric lesions. Br. J. Nutr., v. 106, p. 475-485, 2011.

[18] URBEN A. F., OLIVIERA H. C. B., VIEIRA W., CORREIA, M. J., URIARTT A. H. Produção de cogumelos por meio de tecnologia chinesa modificada. Embrapa, v. 2, p. 151, 2001.

[19] URBEN, A. F. Produção de cogumelos por meio de tecnologia chinesa modificada. Embrapa recursos genéticos e biotecnol. v.2, p. 187, 2004.

[20] WOOD, P.J.; WEISZ, J.; BLACKWELL, B.A. Structural Studies of (1® 3), (1® 4)-b-D-Glucans by 13C-Nuclear Magnetic Resonance Spectroscopy and by Rapid Analysis of Cellulose-like Regions using High-Performance AnionExchange Chromatography of oligosaccharides released by lichenase. Cereal Chem. v. 71, p. 301-307, 1994.

[21] ZHANG M., CUI S. W., CHEUNG P. C. K., WANG, Q. Polysaccharides from mushrooms: a review on their isolation process, structural characteristics and antitumor activity. Trends in Food Sci. Tech. v.18, p. 4-19, 2006.

[22] ZHANG, M.; CUI, S. W.; CHEUNG, P. C. K.; WANG, Q. Antitumor polysaccharide from mushrooms: a review on their isolation process, structural characteristics and antitumor activity. Food Sci. and Technol., v. 18, p. 4-19, 2007. 


\section{Capítulo 9}

Salmonella spp. e coliformes em orégano e alho poró comercializados em feiras livres no município de Pelotas - RS

Tatiane Kuka Valente Gandra

Caroline Pereira das Neves

Eduarda Caetano Peixoto

João Paulo de Paiva Lemos

Vanessa Garcia Monteiro

Eliezer Avila Gandra

Resumo: Os objetivos deste estudo foram quantificar coliformes termotolerantes e verificar a presença de Salmonella spp. em amostras de orégano e alho poró comercializadas em feiras livres no município de Pelotas - RS. 


\section{INTRODUÇÃO}

O orégano (Origanum vulgare L., Lippia Graveolens Kunth) é uma especiaria composta por folhas e talos tradicionalmente utilizados para agregar sabor e aroma em alimentos (BRASIL, 2005). O orégano, pertencente à família Lamiaceae, é muito utilizado para agregar sabor, devido suas características marcantes, é um vegetal considerado como "condimento" ou "tempero", muito utilizado na gastronomia brasileira Na maioria das vezes o orégano é comercializado na forma desidratada (TEIXEIRA et al., 2014). Além disso, o uso de orégano aos alimentos pode resultar em preferência de preparações com menos quantidades de sal, sendo benéfico para a população, especialmente para indivíduos hipertensos (VILLELA et al.,2019).

0 uso do orégano como tempero no dia a dia pode apresentar ainda outros benefícios como o alto potencial antioxidante para sistemas lipídicos e o seu potencial antimicrobiano. 0 orégano e produtos derivados como óleos essenciais e extratos vem sendo estudados como antimicrobianos tendo sido já testado contra microrganismos patogênicos como Salmonella spp. e Staphylococccus aureus (BERNARDI et al., 2019).

O alho-poró (A. ampeloprasum var. porrum) pertence a família Alliaceae, gênero que compreende várias espécies de hortaliças, como por exemplo, alho, cebola e cebolinha (MOREIRA, et al 2019). também conhecido como alho-porro ou alho-francês (EMBRAPA, 2010). 0 alho-poró é fenotipicamente semelhante ao alho, se difere no formato, onde apresenta folhas alongadas e largas com coloração verde escuro (ANDRADE, 2018). 0 seu cultivo teve origem na Ásia Central e desde a antiguidade era utilizado como alimento ou medicamento. No século XXI, o alho-poró continua sendo muito pesquisado devido às qualidades nutricionais e terapêuticas, no Brasil tem a produção concentrada nos Estados da região Sul e Sudeste (FONSECA et al., 2014).

Tanto orégano como alho poró são muito utilizados como tempero e, em alguns casos, como planta medicinal. São comercializados de diferentes formas, as mais comuns são in natura, secos ou desidratados (ALBUQUERQUE, 2015).

Feiras livres são consideradas os lugares mais comuns para comercialização deste tipo de alimento, entretanto, muito se discute sobre as condições higiênico-sanitárias do local de fornecimento e comercialização. As feiras livres são opções para grande parte da população, por oferecer alimentos saudáveis e ampla variedade de preços, são locais muito frequentados (FERREIRA, 2016). Contudo, muitas destas feiras podem apresentar falhas relacionadas as Boas Práticas de Manipulação, podendo assim, serem a origem de diferentes patologias associadas a alimentos (GOMES, et al. 2012).

As especiarias devem ser obtidas, processadas, armazenadas e conservadas de acordo com às Boas Práticas de Fabricação e regulamentos técnicos específicos (BRASIL, 2005). Todavia, o preparo de especiarias está sujeito a falhas no processo de produção, que vai desde a plantação até o consumidor final (SANTOS et al., 2015). Essas falhas podem trazer malefícios ao consumidor, como por exemplo, doenças transmitidas por alimentos (DTA). Para avaliar este risco podem ser utilizados microrganismos indicadores como as bactérias do grupo dos coliformes termotolerantes, que ao estarem presentes em determinada concentração servem de indicativo de condições higiênicos-sanitárias inadequadas. É de grande importância a avaliação de bactérias do grupo dos coliformes em alimentos, pois através do resultado é possível observar a qualidade e segurança do alimento analisado (LUNDGREN, et al 2009). Dentre as espécies deste grupo podemos citar a bactéria de Escherichia coli, que é considerada um agente patogênico causador de infecção alimentar. Estes microrganismos são encontrados na microbiota entérica de animais e seres humanos (NOGUEIRA, et al 2011).

Salmonella spp. é um dos microrganismos mais amplamente distribuídos na natureza, sendo o homem e os animais seus principais reservatórios naturais (SHINOHARA et al., 2008). A Salmonelose é uma das doenças transmitidas por alimentos (DTA) mais preocupantes para a saúde pública em todo o mundo, pelas suas características endêmicas e pelo seu controle depender muito da ação humana, visto que o homem pode ser disseminador dessa bactéria (SILVA \& BITELLO, 2016).

Sendo assim, os objetivos deste estudo foram quantificar coliformes termotolerantes e verificar a presença de Salmonella spp. em amostras de orégano e alho poró comercializadas em feiras livres no município de Pelotas - RS. 


\section{METODOLOGIA}

Foram coletadas 40 amostras de 100 gramas de orégano e 40 amostras de 100 gramas de alho 'poró. As amostras foram adquiridas em feiras livres da cidade de Pelotas - RS. A cada coleta eram adquiridas, na forma como eram comercializadas, duas amostras, totalizando 20 coletas no período de março de 2018 a março de 2020.

As análises microbiológicas foram realizadas de acordo com as recomendações propostas pela American Public Health Association (APHA) (Downes \& ito, 2001) com modificações. As amostras foram pesadas e identificadas assepticamente e submetidas a diluições seriadas até a diluição $10^{-6}$. A análise presuntiva de coliformes foi realizada em Caldo Lauril Sulfato de Sódio (LST), com incubação a $35^{\circ} \mathrm{C}$ por 48 horas. A enumeração de coliformes termotolerantes foi realizada em Caldo Escherichia coli (EC), com incubação a $45,5^{\circ} \mathrm{C}$ por 24 horas. Os resultados foram expressos a partir da técnica do Número Mais Provável (NMP).

Para o isolamento de Salmonella spp. foi realizado pré-enriquecimento em água peptonada tamponada a $37^{\circ} \mathrm{C}$ por 24 horas, enriquecimento seletivo em Caldo Rappaport-Vassiliadis a $42^{\circ} \mathrm{C}$ por 24 horas e Caldo Tetrationato a $37^{\circ} \mathrm{C}$ por 24 horas. Em seguida, foi feito semeadura em placas de Ágar Desoxicolato-LisinaXilose (XLD) e Ágar Hektoen-Enteric (HE), sendo ambos incubados por 24 horas a $37^{\circ} \mathrm{C}$. Colônias típicas foram submetidas à identificação bioquímica em Ágar Tríplice Ferro (TSI), Ágar Lisina Ferro (LIA) e Ágar Urease a $37^{\circ} \mathrm{C}$ por 24 horas. As amostras que apresentaram reação bioquímica característica foram submetidas à identificação sorológica, utilizando-se os soros polivalentes anti-salmonella somático e flagelar (Probac).

\section{RESULTADOS E DISCUSSÃO}

Na Tabela 1 estão dispostos os resultados obtidos para e coliformes termotolerantes nas amostras de orégano analisadas.

Tabela 1 - Quantificação de coliformes termotolerantes em 40 amostras de orégano vendidos em feiras livres da cidade de Pelotas-RS, Brasil, 2018-2020.

\begin{tabular}{|c|c|}
\hline Amostra ( $\mathrm{n})$ & Coliformes termotolerantes n (\%)* \\
\hline Orégano (40) & $4(1)$ \\
\hline \multicolumn{2}{|c|}{$\mathrm{n}$ - número de amostras analisadas. }
\end{tabular}

*Amostras com contagens acima do valor máximo permitido pela Instrução Normativa N 60 (BRASIL, 2019.)

Foram analisadas 40 amostras de orégano destas, 4 estavam com concentração acima do máximo permitido, estando impróprias para o consumo, representando $10 \%$ das amostras analisadas, o que indica falhas na qualidade higiênico-sanitária do produto. Uma das possíveis explicações para este resultado está no fato que algumas feiras livres possuem deficiência nos processos de higienização, bem como nas Boas Práticas de Manipulação. 0 problema que dentre estes microrganismos encontrados podem estar os patogênicos que podem ocasionar DTA, gerando, por exemplo, comprometimento do sistema digestório, podendo causar náuseas, vômitos e crise de dores gástricas (ALVES, 2013). Este resultado não está restrito as feiras de Pelotas-RS, um trabalho realizado por Assis (2016) analisou a presença de microrganismos, como leveduras, bactérias e fungos em especiarias, comercializadas em feiras livres e mercados do município de Cuiabá-MT, das 35 amostras analisadas $80 \%$ apresentaram a presença de leveduras e $70 \%$ de bactérias. Outro estudo verificou a presença de coliformes termotolerantes em amostras de coco ralado, comercializados em feiras livres, todas as amostras analisadas estavam acima da contagem permitida pela legislação (ABREU et al., 2018). A contaminação em feiras livres pode ocorrer de diferentes maneiras, a mais comum, é resultante da falta de conhecimento dos próprios manipuladores (RODRIGUES, 2015).

Na Tabela 2 estão dispostos os resultados obtidos para e coliformes termotolerantes em amostras de alhoporó. 
Tabela 2 - Quantificação de Coliformes Termotolerantes em 40 amostras de alho-poró vendidos em feiras livres da cidade de Pelotas-RS, Brasil, 2018-2020.

\begin{tabular}{|c|c|}
\hline Amostra $(\mathrm{n})$ & Coliformes termotolerantes $\mathrm{n}(\%)^{*}$ \\
\hline Alho poró $(40)$ & $8(40)$ \\
\hline \multicolumn{2}{|c|}{$\mathrm{n}-$ número de amostras analisadas. }
\end{tabular}

*Amostras com contagens acima do valor máximo permitido pela Instrução Normativa $N^{\circ} 60$ (BRASIL, 2019.)

Foram analisadas 40 amostras de alho-poró, destas 8 estavam impróprias para o consumo, representando $20 \%$ das amostras, indicando deficiência na qualidade higiênico-sanitária do produto.

A provável explicação para os resultados encontrados pode ser associada ao fato que feiras livres geralmente possuem condições precárias de higiene. Baseado nisto, as pesquisas microbiológicas em alimentos comercializados nestes ambientes são crescentes.

Uma pesquisa realizada por Viana et al. (2016) constatou que os alimentos comercializados em feiras livres geralmente são mantidos sob baixas condições de higiene, incluindo as tendas e utensílios. Silva et al. (2015), analisando a qualidade microbiana de saladas de frutas manipuladas em feiras livres, verificaram péssimas condições higiênico-sanitárias, bem como a presença de E. coli, o que pode trazer riscos para saúde do consumidor, devido a este microrganismo ser causador de infecções alimentares. Um trabalho experimental, realizado por Macedo et al. (2016) avaliou a prevalência de coliformes e Staphylococcus aureus em mãos de manipuladores de alimentos de uma feira livre de Vitória, ES. Os resultados indicaram que os manipuladores são possíveis veiculadores de bactérias patogênicas. Comparando com outro trabalho realizado, Costa et al. (2009), estudou o perfil microbiológico de diferentes amostras de alimentos vendidos em feiras livres no município de Goiânia, GO. Foram analisadas 196 amostras, foi constatado que 22 amostras apresentaram contagem acima dos padrões permitidos pela legislação para coliformes termotolerantes (coliformes a $45^{\circ} \mathrm{C}$ ), tais resultados estão em acordo aos encontrados em nosso estudo e denotam uma situação preocupante, considerando que estes microrganismos podem implicar em riscos à saúde dos consumidores.

Na tabela 3 estão dispostos os resultados obtidos para Salmonella spp. em amostras de orégano. Quatro amostras $(10 \%)$ de orégano apresentaram Salmonella spp., estando fora do padrão microbiológico preconizado pela legislação brasileira (ausência de Salmonella spp. em 25 gramas de alimento), sendo assim, inadequadas para o consumo.

Tabela 3 - Pesquisa de Salmonella spp. em 40 amostras de orégano vendidos em feiras livres da cidade de Pelotas - RS, Brasil, 2018 - 2020.

\begin{tabular}{|c|c|}
\hline Amostra(n) & Salmonella spp. $\mathrm{n}(\%)^{*}$ \\
\hline Orégano (40) & $4(10)$ \\
\hline
\end{tabular}

Legenda: $\mathrm{n}$ - número de amostras analisadas; *Amostras com a presença de Salmonella spp.

Salmonella spp. foi o segundo agente etiológico mais identificado em surtos de Doenças Transmitidos por Alimentos no Brasil entre os anos de 2009 e 2018 (BRASIL, 2019). Surtos de Salmonelose são uma importante fonte de redução da produtividade econômica. Apesar de a maioria das infecções humanas por Salmonella spp. estarem associadas a carnes e produtos lácteos, surtos de Salmonelose tem sido relacionados com uma variedade de frutas e vegetais, isso porque essas bactérias podem multiplicar-se na superfície desses alimentos (CAETANO \& PAGANO, 2019; FORSYTHE, 2013).

Levando em consideração o uso do orégano nas preparações culinárias, a realização de Boas Práticas de Manipulação como higiene de mãos, cozimento das preparações a temperaturas acima dos $70^{\circ} \mathrm{C}$, separação alimentos crus e cozidos, e higienização de alimentos consumidos crus são medidas necessárias para garantir a qualidade higienicossanitária da preparação, evitando a infecção por Salmonella spp. e outros micro-organismos patogênicos (BRASIL, 2004; FORSYTHE, 2013).

Na Tabela 4 estão dispostos os resultados obtidos para Samonella spp em amostras de alho-poró. 
Tabela 4- Pesquisa de Samonella spp. em 40 amostras de alho-poró vendidos em feiras livres da cidade de Pelotas-RS, Brasil, 2018-2020.

\begin{tabular}{|c|c|}
\hline Amostra (n) & Salmonella spp. n (\%)* \\
\hline Alho poró (40) & $2(5)$ \\
\hline \multicolumn{2}{|c|}{$\mathrm{n}$ - número de amostras analisadas. } \\
*Amostras com a presença de Salmonella spp.
\end{tabular}

Entre as 40 amostras de alho-poró analisadas, duas (10\%) apresentaram contaminação por Salmonella spp., a legislação estabelece que Salmonella spp. em raízes, tubercúlos e similares deve ser ausente em 25g. Embora haja poucas pesquisas referentes a contaminação do alho-poró, a observação de alimentos diferentes relacionados ao mesmo microrganismo permitiu concluir que a manipulação inadequada é o principal fator de contaminação (KOTTWITZ et al., 2008) e esta pode ser a provável causa da presença de Salmonella em duas amostras neste estudo.

Considerando que a Salmonelose é grande responsável pela maioria das infecções alimentares humanas (TIROLLI \& COSTA, 2006) os resultados encontrados denotam um risco potencial e a necessidade de adequação as Boas Práticas de Manipulação na produção e comercialização neste tipo de produto.

Na maioria das feiras livres a contaminação pode ocorrer em diferentes pontos, o mais comum é através dos manipuladores. Uma provável explicação para este fato está na falta de conhecimento sobre o assunto, um questionário aplicado por RODRIGUES (2015) interrogou os participantes sobre o conhecimento do meio de transmissão de doenças através de alimentos, como resultado, a maior parte dos entrevistados desconhece os meios de contaminação de alimentos. Indicando a falta de debate do assunto ou até mesmo instruções de maneira que visam evitar possíveis DTAs.

\section{CONSIDERAÇÕES FINAIS}

A partir dos resultados obtidos neste estudo fica evidente a necessidade de orientação, treinamento e conscientização dos feirantes e produtores rurais, principalmente daqueles que trabalham com alimentos in natura como o alho-poró e o orégano, para que possam implementar Boas Práticas de Manipulação de alimentos, , desta forma, reduzindo-se riscos de contaminação alimentar.

\section{REFERÊNCIAS}

[1] ABREU, M., G., G.; ANGELIM, E., S.; MENDO, M., J., S., F.; RIBEIRO, S., M., A. Avaliação microbiológica de coco (Cocos nucifera) ralado comercializado em feiras livres do município de Belém, estado do Pará, Brasil. Rer. PanAmazônica. V.9 n.1 jan-mar. 2018.

[2] ALBUQUERQUE, J.; R.; A. DESEMPENHO AGROMORFOLÓGICO DE VARIEDADES CRIOULAS DE ALHO. UNIVERSIDADE FEDERAL DO PIAUÍ CENTRO DE CIÊNCIAS AGRÁRIAS NÚCLEO DE PÓS-GRADUAÇÃO EM CIÊNCIAS AGRÁRIAS PROGRAMA DE PÓS-GRADUAÇÃO EM AGRONOMIA/PRODUÇÃO VEGETAL. 2015.

[3] ALVES V. de O. Avaliação Higiênico-sanitária de Amostras de queijos Minas Frescal Artesanais comercializados em Feiras Livres da cidade de Volta Redonda-RJ e sucetibilidade antimicrobiana das estirpes patogênicas isoladas. Dissertação apresentada ao Programa de Pós Graduação em Medicina Veterinária da Faculdade de Veterinária da Universidade Federal Fluminense, 2013.

[4] ANDRADE, M.; T. DIVERSIDADE DE ISOLADOS DE Alternaria spp. ASSOCIADOS AO GÊNERO Allium NO BRASIL. Universidade de Brasília - UnB, 2011.

[5] ASSIS, Ávila Ferreira de. Análise microbiológica de especiarias e condimentos comercializados no município de Cuiabá/MT. 31 f. TCC (Especialização em Microbiologia) - Universidade Federal de Mato Grosso, Instituto de Biociências, Cuiabá, 2016.

[6] BERNADI, D.M.; DE MELLO, H.R.L.S.; ALMEIDA, L.T.; MARAGON, L.M. Composição e propriedades funcionais de frutas, bebidas e temperos. Cascavel: FAG, 2019. 236.

[7] BRASIL, ANVISA. RDC № 276, de 22 de setembro de 2005. Regulamento técnico para especiarias, temperos e molhos. Diário Oficial da União, Poder Executivo. ANVISA - Agência Nacional de Vigilância Sanitária. Brasil, 2005.

[8] BRASIL, ANVISA. RDC: № 12, de 02 de janeiro de 2001. Aprova o Regulamento Técnico sobre Padrões Microbiológicos para Alimentos. Diário Oficial da União, Poder Executivo. ANVISA - Agência Nacional de Vigilância Sanitária. Brasil, 2001. 
[9] BRASIL. Ministério da Saúde. 2018. Surtos de doenças transmitidas por alimentos no Brasil. Brasília.

[10] BRASIL. Ministério da Saúde. Surtos de Doenças Transmitidas por Alimentos no Brasil: Informe 2018. Brasília, 2020. Disponível em: http://portalarquivos2.saude.gov.br/images/pdf/2019/fevereiro/15/Apresenta----oSurtos-DTA---Fevereiro-2019.pdf. Acesso em: 07 de jul. 2020.

[11] BRASIL. INSTRUÇÃO NORMATIVA Nº 60, DE 23 DE DEZEMBRO DE 2019 Aprova o Regulamento Técnico sobre Padrões Microbiológicos para Alimentos. Diário Oficial da União, Publicado em 26/12/2019, Edição: 249, Seção: 1, Página 133, Poder Executivo. ANVISA - Agência Nacional de Vigilância Sanitária. Brasil, 2019.

[12] BRASIL. Resolução RDC n. 216, de 15 de setembro de 2004. Dispõe sobre

[13] BRASIL. Resolução RDC n. 276, de 22 de setembro de 2005. Aprovar o "REGULAMENTO TÉCNICO PARA ESPECIARIAS, TEMPEROS E MOLHOS”. Brasília: Diário Oficial da União, 2005.

[14] CAETANO, F.; PAGANO, M. Prevalência de infecções causadas por Salmonella sp. no Brasil no período de 2013 a 2017. Journal of Infection Control, 8, 2, 56-62, Abr-Jun 2019.

[15] COSTA, R. M.; REZIO, M. A.; SANTANA, R. G. M.; CARVAlHO, B. A.; AGOSTINHO, T. M. S.; MONEGO, E. T.; CAMPOS, R. H. Perfil microbiológico de alimentos comercializados em feiras especiais de Goiânia, Goiás. Revista Higiene Alimentar, Mirandópolis, v. 23, n. 170171, p. 60-61, 2009.

[16] Diário Oficial da União, 2004.

[17] DOWNES, F. P.; ITO, H. Compendium Of Methods for the microbiological examination of foods.. 4. ed. Washington: American Public Health Association (APHA), 676 p. 2001.

[18] Embrapa. Catálogo Brasileiro de Hortaliças: Saiba como plantar e aproveitar 50 das espécies mais comercializadas no país. Brasília. Embrapa Hortaliças. 60 p, 2010. Disponível em:< http://www.ceasa.gov.br/dados/publicacao/Catalogo\%20hortalicas.pdf >. Acesso em: 28 de julho de 2020.

[19] FERREIRA, E., P. ANÁLISE MICROBIOLOGICA DE COLIFORMES TOTAIS E TERMOTOLERANTES EM QUEIJOS COMERCIALIZADOS EM FEIRAS LIVRES NO MUNICIPIO DE PORTO VELHO - RO. Trabalho de conclusão de curso de Bacharel em Biomedicina. CENTRO DE ENSINO SÃO LUCAS. Porto Velho. 2016.

[20] FONSECA, G. M.; Passos, T. C.I; Ninahuaman, M. F. M. L.; Caroci, A. S.; Costa, L.S. Avaliação da atividade antimicrobiana do alho (Allium sativum Liliaceae) e de seu extrato aquoso .. Rev. bras. plantas med. Vol.16 no.3 supl.1 Botucatu 2014

[21] FORSYTHE, S.J. Microbiologia da segurança dos alimentos. 2ª ed. Porto Alegre: Artmed, 2013. 620.

[22] GOMES, P., M., A.; BARBOSA, J., G.; COSTA, E., R.; Avaliações das condições higiênicas sanitárias das carnes comercializadas na feira livre do município de Catolé do Rocha-PB. Revista Verde. jan-mar;7(1):225-32. 2012.

[23] Kottwitz, L.B.M.; Back, A.; Leão, J. A.; Alcocer, I.; Karan, M.; Oliveira, T.C.R.M. Contaminação por Salmonella spp. em uma cadeia de produção de ovos de uma integração de postura comercial .. Arq. Bras. Med. Vet. Zootec. Vol.60 no.2 Belo Horizonte Apr. 2008

[24] LUNDGREN, P.; U. et al. PERFIL DA QUALIDADE HIGIÊNICO-SANITÁRIA DA CARNE BOVINA COMERCIALIZADA EM FEIRAS LIVRES E MERCADOS PÚBLICOS DE JOÃO PESSOA/PB-BRASIL.. Alim. Nutr., Araraquara v.20, n.1, p. 113-119, jan./mar. 2009.

[25] MACEDO, V., F.; ZANARDO, J., G.; LOPES, R., P., C.; MENDONÇA, H., F., M., S.; RAYMUNDO, N., L., S.; MORAES, R. Prevalência de coliformes e Staphylococcus aureus em mãos de manipuladores de alimentos de feira livre de Vitória, ES. Revista Salus Jornal Health Sci. i. 2(2): 27-38. 2016.

[26] MOREIRA, M. G. O. et al. ATIVIDADE TERAPÊUTICA DO Allium sativum COMO ANTIFÚNGICO: REVISÃO DE LITERATURA. Mostra Científica da Farmácia, [S.l.], v. 6, n. 1, jul. 2019. ISSN 2358-9124. Disponível em: <http://publicacoesacademicas.unicatolicaquixada.edu.br/index.php/mostracientificafarmacia/article/view/3525>. Acesso em: 31 Jul. 2020.

[27] NOGUEIRA, M.; S. et al. QUALIDADE HIGIÊNICO-SANITÁRIA E MICROBIOLÓGICA DA CARNE BOVINA COMERCIALIZADA NO MUNICÍPIO DE AREIA-PB. Agropecuária Técnica - v. 32, n. 1. ISSN 0100-7467 - Areia, PB CCA-UFPB. 2011.

[28] NOGUEIRA, M.; S. et al. QUALIDADE HIGIÊNICO-SANITÁRIA E MICROBIOLÓGICA DA CARNE BOVINA COMERCIALIZADA NO MUNICÍPIO DE AREIA-PB. Agropecuária Técnica - v. 32, n. 1, 2011 ISSN 0100-7467 - Areia, PB - CCA-UFPB.

[29] RODRIGUES, D. N. J. Avaliação do conhecimento da população sobre as formas da transmissão e medidas preventivas da toxoplasmose em Mossoró - RN. Trabalho de conclusão de curso - UFERSA 2015.

[30] RODRIGUES, D. N. J. Avaliação do conhecimento da população sobre as formas da transmissão e medidas preventivas da toxoplasmose em Mossoró - RN. Trabalho de conclusão de curso - UFERSA 2015. 
[31] SANTOS, G. G.; MATTOS, L. M; MORETTI, C. L. Qualidade microbiológica e presença de resíduos microscópicos em derivados de tomate. In: SIMPÓSIO DE SEGURANÇA ALIMENTAR ALIMENTAÇÃO E SAÚDE. Bento Gonçalves. Anais

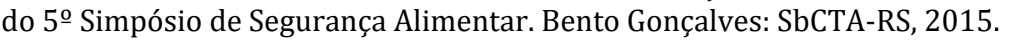

[32] Shinohara, N. K. S.; Barros, V. B.; Jimenez, S. M. C.; Machado, E. C. L.; Dutra, R. A. F.; Filho, J. L. L. Salmonella spp., importante agente patogênico veiculado em alimentos SciELO - Scientific Electronic Library Online v. 13 n. 5 , 2008. ISSN 1675-1683

[33] SILVA, N. ANÁLISE DO RESULTADO FINANCEIRO DO CULTIVO DE ALHO: ESTUDO EM PROPRIEDADES RURAIS DE PEQUENO PORTE DE SANTA CATARINA. Universidade Federal do Paraná. 2016.

[34] SILVA, T., C.; CARVALHO, C., T.; LUZ, J., R., D.; ARAÚJU, L., B., A. Salada de frutas no conceito street food: avaliação de qualidade microbiológica. Rev Nutr Vigil Saude. nov;2(3):128-33. 2015.

[35] Silva, V. M.; Bitello, A. R. Verificação da presença de Salmonella spp em alimentos minimamente processados em um munipío do interior do Rio Grande do Sul .. Revista Destaques Acadêmicos, Lajeado, v. 8, n. 3, p. 109-115, 2016. ISSN 2176-3070

[36] TEIXEIRA-LOYOLA, A. B. A. et al. Análise Microbiológica de especiarias comercializadas em Pouso Alegre. Minas Gerais. Revista Eletrônica Acervo Saúde, Pouso Alegre, v. 6, n. 1, p. 515-529, 2014.

[37] Tirolli I. C. C.; Costa , C. A. Ocorrência de Salmonella spp. em carcaças de frangos recém abatidos em feiras e mercados da cidade de Manaus-AM .. Acta Amaz. Vol.36 no.2 Manaus 2006

[38] VIANA, I., VALIATI, T., B.; SOBRAL F., O., S.; ROMÃO N., F.; FONSECA C., X.; OLIVEIRA U., A. Análise microbiológica do tambaqui (Colossoma macropomum) comercializado na feira municipal de Ariquemes, Estado de Rondônia. Brasil. Rev Pan-Amaz Saude. jun;7(2):67-73. 2016.

[39] VILlELA, P.T.M.; DE-OLIVEIRA, E.B.; VILLELA, P.T.M.; BONARDI, J.M.T.; BERTANI, R.F.; MORIGUTI, J.C.; FERRIOLLI, E.; LIMA, N.K.C. A Preferência ao Sal está Relacionada à Hipertensão e não ao Envelhecimento. Arquivos Brasileiros de Cardiologia. 113, 3, 392-399, 2019. 


\section{Capítulo 10}

\section{Avaliação da toxicidade do óleo essencial de tomilho (Thymus vulgaris L.)}

\section{Adriana Biasi Vanin \\ Gláucia Freiberger \\ Bruna Albiero \\ José Carlos Azzolini}

Resumo: Plantas medicinais são comumente utilizadas pela população, devido seus efeitos terapêuticos. A forma de chás e infusões é mais aplicada, mas diversas ervas aromáticas também são empregadas como temperos em receitas, como é o caso do Thymus vulgaris L., conhecido como tomilho. Na medicina tradicional o tomilho é usado para tratar distúrbios gastroentéricos e broncopulmonares. No entanto, os compostos bioativos podem se tornar tóxicos se consumidos de doses elevadas. 0 presente estudo teve como objetivo avaliar a toxicidade do óleo essencial de Thymus vulgaris L. por meio do bioensaio com Artemia salina. Para o ensaio os cistos de Artemia salina foram colocados para eclodir em solução salina artificial durante 24 h. Após, as larvas foram expostas a diferentes concentrações do óleo essencial de Thymus vulgaris. Após $24 \mathrm{~h}$ quantificou-se o número cistos vivos. Os resultados obtidos demonstraram que o óleo essencial de tomilho com $\mathrm{CL}_{50}$ de $0,33884 \mu \mathrm{g} / \mathrm{mL}$ é potencialmente tóxico, indicando que, se ingerido em doses inadequadas pode ocasionar intoxicações.

Palavras-Chave: Óleo essencial, tomilho, toxicidade, Artemia salina. 


\section{INTRODUÇÃO}

Diversas espécies de plantas são utilizadas com finalidades medicinais desde a antiguidade, porém muitas delas não possuem a comprovação de suas propriedades farmacológicas. Com o uso destes materiais naturais durante os anos, foi percebido que determinadas plantas apresentam substâncias tóxicas que traziam riscos à saúde, assim devendo ser utilizadas com cuidado (VEIGA JUNIOR; PINTO; MACIEL, 2004).

Segundo a descrição da Anvisa, contida na Resolução n.o 10 de março de 2010, planta medicinal é toda espécie vegetal, cultivada ou não, utilizada com propósitos terapêuticos, capaz de aliviar ou curar enfermidades além de ter tradição de uso como remédio em uma população, ou comunidade, normalmente são utilizadas em forma de chás e infusões. Já o conceito de fitofármaco é a substância ativa, isolada de matérias-primas vegetais ou mesmo, mistura de substâncias ativas de origem vegetal.

Apesar da medicina moderna ser bem desenvolvida na maior parte do mundo, a Organização Mundial da Saúde (OMS), na Declaração de Alma-Ata de 1978, estima que aproximadamente $80 \%$ da população mundial faça uso de práticas medicinais tradicionais como atenção primária à saúde, principalmente nos países em desenvolvimento, e $85 \%$ usam plantas medicinais ou preparações feitas a partir delas. De acordo com Gurib-Fakim (2006), as formulações baseadas em substâncias derivadas de plantas ou análogos sintéticos derivados delas contribuem com no mínimo $25 \%$ de todas as prescrições médicas de uso clínico.

A espécie Thymus vulgaris L., conhecida como tomilho, é uma erva perene indígena originária da região central e sul da Europa e amplamente utilizada na medicina popular no tratamento de distúrbios gastroentéricos e broncopulmonares, devido às suas conhecidas propriedades sedativas, carminativas, diaforéticas, antimicrobiana e anti oxidantes (NIKOLIĆ et al., 2014).

0 tomilho além se ser utilizado para efeito terapêutico, assim como outras plantas aromáticas, também é largamente aplicado como tempero em receitas, entretanto compostos bioativos se consumidos em elevadas quantidades podem se tornar tóxicos. Segundo Ferreira e Pinto (2010), a população tem a falsa percepção de que todo produto natural é seguro e não apresenta efeitos colaterais.

Assim, a investigação do potencial tóxico de plantas medicinais pode elucidar importantes aspectos farmacológicos de seus princípios naturais, permitindo uma utilização segura, respeitando seus possíveis riscos toxicológicos (AMARAL \& SILVA, 2008).

Compostos bioativos são quase sempre tóxicos em altas doses. Desta maneira, a avaliação da letalidade em um organismo animal menos complexo pode ser usada para um monitoramento simples e rápido. 0 microcrustáceo Artemia Salina, foi selecionado para os ensaios de toxicidade por apresentar algumas vantagens como a sua abundância, a facilidade de se manter ou de se cultivar em laboratório, sua representatividade no ecossistema, sua sensibilidade, disponibilidade suficiente de informação (FERREIRA, 2001) e correlação com a citotoxicidade diante de linhagens de células humanas de tumores sólidos (McLAUGHLIN, 1991).

Diante disso, esta pesquisa objetiva avaliar a toxicidade do tomilho utilizando náuplios do microcrustáceos de Artemia Salina, um organismo animal menos complexo, o que torna seu monitoramento mais simples e rápido, garantindo maior segurança na sua utilização desta erva (CANSIAN et al., 2017).

\section{MATERIAIS E MÉTODOS}

Para os ensaios, foi utilizado o óleo essencial comercial de tomilho (Thymus vulgaris L.) da marca WNF. Para a avaliação da toxicidade utilizou-se o bioensaio de letalidade para larvas de Artemia salina por meio da metodologia descrita por Meyer et al. (1982), com algumas modificações. Os cistos do microcrustáceo Artemia salina foram colocados em um recipiente plástico com solução salina artificial $(23 \mathrm{~g}$ de sal marinho/1 litro de água destilada/0,7 g de bicarbonato de sódio), sob iluminação artificial, aeração e controle da temperatura $\left(20-30^{\circ} \mathrm{C}\right)$ para a eclosão dos ovos por 24 horas. 
Após 24 horas, as larvas foram expostas a diferentes concentrações $(0,009 ; 0,01 ; 0,02 ; 0,03 ; 0,04 ; 0,05$; 0,06; 0,07; 0,08 e 0,09 $\mu \mathrm{L} / \mathrm{mL}$ ) do óleo essencial de Thymus vulgaris por 24 horas, utilizando-se tubos de ensaio, cada um contendo 10 náuplios, nas 10 diferentes concentrações, cada uma em triplicata constituindo um ensaio, buscando sempre a maior concentração em que se observasse $0 \%$ de mortalidade e a menor concentração em que se deflagrasse $100 \%$ de mortalidade, de modo a obter a CL50 (concentração letal média). As soluções foram preparadas em 2\% de DMSO (dimetilsulfóxido) e avolumadas com solução salina artificial. Após 24h de exposição, foi realizada a contagem de náuplios sobreviventes e os resultados foram submetidos a tratamento estatístico utilizando a regressão linear. A CL50 foi calculada a partir do gráfico do percentual de animais mortos (Equação 1) contra o logaritmo das doses ensaiadas. Esse valor foi verificado através do método de regressão linear.

$\%$ mortalidade $=100-(\mathrm{IVm} \times 100) / \mathrm{CNm}$

Onde CNm é a média do controle negativo e IVm corresponde à média de indivíduos vivos por concentração após $24 \mathrm{~h}$.

\section{RESULTADOS E DISCUSSÃO}

Como teste de triagem, os ensaios com Artemia salina estão se destacando na indicação de atividade antitumoral. Segundo Mclaughlin, (1991), o fato de se trabalhar com organismos relativamente simples torna mais fácil a indução de um retardo ou paralisação do ciclo celular normal por provocar alteração do processo mitótico. McLaughlin (1991) observou uma ótima correlação entre o teste de toxicidade frente Artemia salina e o teste de citotoxicidade, usando células 9K (carcinoma humano de nasofaringe) e a partir desses resultados, utilizou o teste de Artemia salina como pré-screening para testes de citotoxicidade com seis linhagens de células tumorais sólidas humanas. Este autor observou que a ED50 (dose eficiente 50\%) nos testes de citotoxicidade é geralmente em torno de um décimo da DL50 encontrada no teste com esse microcrustáceo. Os resultados referentes à toxicidade do óleo essencial de tomilho estão apresentados abaixo (Tabela 1).

Tabela 1: Mortalidade média de Artemia salina de acordo com as concentrações do óleo essencial de tomilho.

\begin{tabular}{|c|c|}
$\begin{array}{c}\text { Concentração } \\
{[\mu \mathrm{L} / \mathrm{mL}]}\end{array}$ & $\begin{array}{c}\text { Média de náuplios } \\
\text { mortos }(\%)\end{array}$ \\
\hline 0,009 & $17 \pm 15,2$ \\
\hline 0,01 & $17 \pm 15,2$ \\
\hline 0,02 & $25 \pm 2,9$ \\
\hline 0,03 & $45 \pm 8,4$ \\
\hline 0,04 & $52 \pm 3,2$ \\
\hline 0,05 & $70 \pm 3,0$ \\
\hline 0,06 & $94 \pm 5,5$ \\
\hline 0,07 & $100 \pm 0,0$ \\
\hline 0,08 & $100 \pm 0,0$ \\
\hline 0,09 & $100 \pm 0,0$ \\
\hline
\end{tabular}

Os resultados demonstraram que o percentual de mortalidade aumenta proporcionalmente à concentração de óleo essencial adicionado, atingindo o valor máximo de $100 \%$ a partir da concentração de $0,07 \mu \mathrm{L} / \mathrm{mL}$. No ensaio com o grupo controle, não foi verificado mortalidade o que demonstra que a utilização do DMSO como solvente é viável. Após a identificação da faixa de concentração, a CL50 do óleo essencial de Thymus vulgaris L, foi determinada como mostra o Gráfico 1. 
Gráfico 1: Curva de calibração da toxicidade do essencial de tomilho

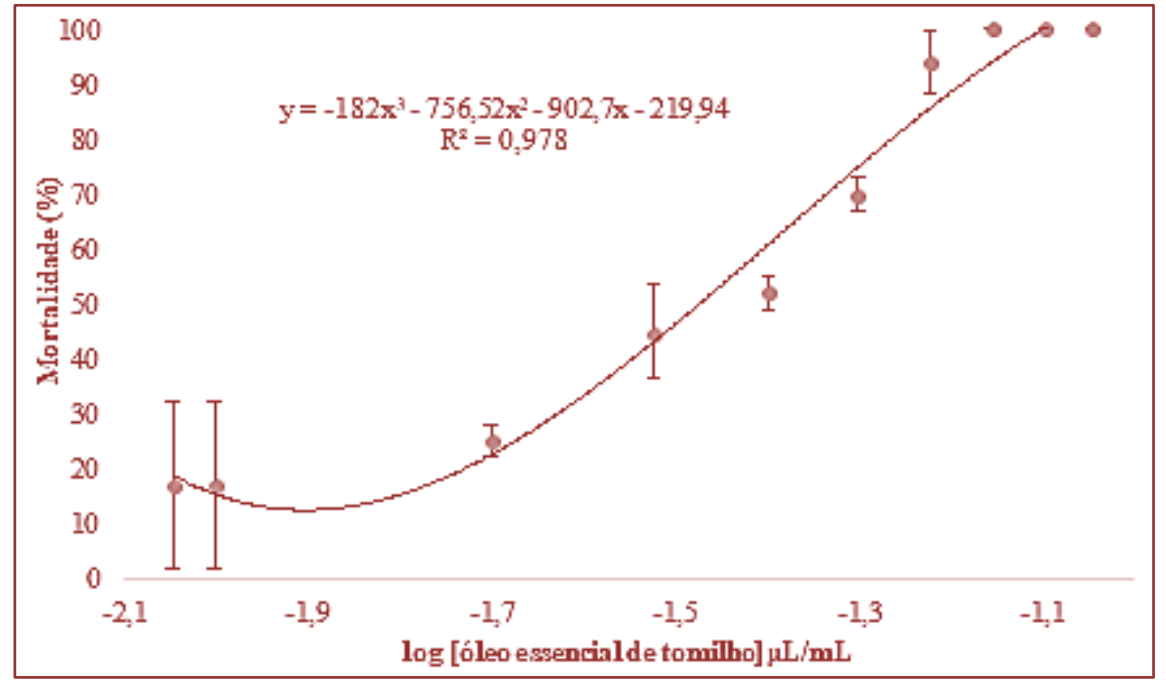

A correlação entre a mortalidade (\%) e o logaritmo da concentração de óleo essencial de T. vulgaris $(\mu \mathrm{L} / \mathrm{mL}),\left(\mathrm{y}=-182 \mathrm{x}^{3}-756,52 \mathrm{x}^{2}-902,7 \mathrm{x}-219,94\right)$ com $\mathrm{R}^{2}=0,978$, forneceu uma $\mathrm{CL}_{50}$ de $0,033884 \mu \mathrm{L} / \mathrm{mL}$, o que corresponde a $0,33884 \mu \mathrm{g} / \mathrm{mL}$. Lazarević et al. (2020) em sua análise sobre a toxicidade de $T$. vulgaris sobre o gorgulho Acanthoscelides obtectus, obtiveram $\mathrm{CL}_{50}=0,850 \%$ para insetos fêmeas e $\mathrm{CL}_{50}=$ $0,574 \%$ para insetos machos.

0 critério de classificação da toxicidade de óleos essenciais frente à $A$. salina com base nos valores das $\mathrm{DL}_{50}$ foi estabelecido por Donabela (1997), onde $\mathrm{DL}_{50} \leq 80 \mu \mathrm{g} / \mathrm{mL}$ corresponde ao produto altamente tóxico, $\mathrm{DL}_{50}$ entre 80 a $250 \mu \mathrm{g} / \mathrm{mL}$, o produto é moderadamente tóxico e $\mathrm{DL}_{50} \geq 250 \mu \mathrm{g} / \mathrm{mL}$, o produto é levemente tóxico ou atóxico. Já Meyer et al. (1982), utilizam o critério de avaliação em que considera as substâncias tóxicas ou ativas quando apresentam $\mathrm{DL}_{50}<1000 \mu \mathrm{g} / \mathrm{mL}$ e atóxicas ou inativas quando apresentam $\mathrm{DL}_{50}>1000 \mu \mathrm{g} / \mathrm{mL}$.

Em estudo realizado por Nikolić et al. (2014) foram identificados como componentes majoritários do óleo essencial da espécie T. vulgaris o timol (49,1\%), o $\beta$-cimeno (20,0\%), o $\gamma$-terpineno (4,2\%) e o carvacrol (3,7\%). Romero et al. (2009) também observaram, por meio da análise de CG-EM, os principais constituintes de T. vulgaris como sendo o timol (50\%), $\beta$-cimeno (20\%), $\gamma$-terpineno (18\%) e carvacrol (4,5\%). Já Ferreira et al. (2016) determinaram, pela técnica GC-MS, as porcentagens de 50,22\% de timol, $23,76 \%$ de $\beta$-cimeno, 6,00\% de $\gamma$-terpineno e 4,75\% de linalol como substâncias constituintes do óleo de T. vulgaris. A Figura 1 representa as estruturas químicas dos compostos citados.

A variação na porcentagem dos componentes majoritários pode ser decorrente de fatores que alteraram a taxa de produção de metabólitos secundários. De acordo com Gobbo-Neto e Lopes (2007), as principais causas de influência nos metabólitos secundários, como o óleo essencial, são a época em que a planta é coletada, sazonalidade, índice pluviométrico, ciclo circadiano, temperatura, radiação UV (incidência luminosa), idade e desenvolvimento da planta, disponibilidade hídrica e de nutrientes, estímulos mecânicos ou ataque de patógenos, composição atmosférica e altitude.

Segundo Baser (2008), o carvacrol e o timol são fenóis monoterpênicos, isômeros entre si, contendo as funções metil e isopropil na posição "para" em cada anel aromático, sendo que a diferença entre suas fórmulas químicas está na posição do grupo hidroxila, enquanto o carvacrol é líquido à temperatura ambiente, o timol apresenta-se na forma de cristais. Pelo fato de o carvacrol e o timol serem biossintetizados a partir do $\gamma$-terpineno, através do $\beta$-cimeno, os quatro compostos são sempre identificados juntos em óleos essenciais.

A atividade realizada pelo sinergismo entre o timol e o carvacrol apresenta efeitos tóxicos a diversos organismos, incluindo a lagarta-militar do tabaco, Spodoptera litura, as larvas-de-cascudinho, Alphitobius diaperinus e ao gorgulho do arroz, Sitophilus oryzae. 0 mecanismo de ação desses compostos, em insetos, ocorre através da inibição da enzima acetilcolinesterase (AchE), responsável pelo funcionamento do sistema nervoso (MENEZES, 2016). 
Figura 1: Estrutura química dos constituintes majoritários do óleo essencial de T. vulgaris

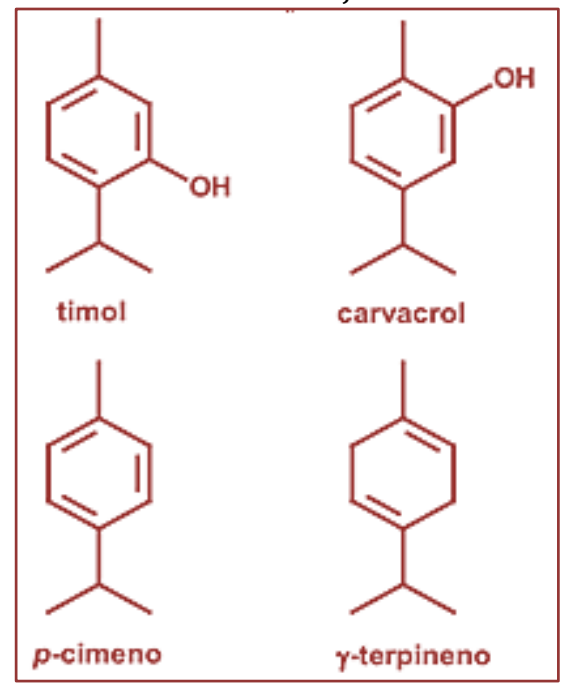

Fonte: Romero et al. (2009).

\section{CONCLUSÕES}

Tendo em vista a grande cultura no que se refere à utilização de plantas no tratamento de doenças, estudos referentes à toxicidade de compostos naturais são certamente muito importantes. Segundo os resultados encontrados neste trabalho, à primeira vista, o óleo essencial de tomilho continua sendo uma opção para a aplicação em alimentos, no entanto, avaliando os resultados da análise constatou-se que o óleo essencial é altamente tóxico, de acordo com a classificação de Dolabella (1997). Para utilizar as plantas medicinais de forma segura, é necessário que se conheça seus potenciais tóxicos, assim comprovando viabilidade do estudo.

\section{REFERÊNCIAS}

[1] AMARAL, E.A.; SILVA, R. M. G. Avaliação da Toxidade Aguda de Angico (Anadenanthera falcata), pau-santo (Kilmeyera coreacea), aroeira (Myracrodruon urundeuva) e cipó-de-são-joão (Pyrostegia venusta), por meio do bioensaio com Artemia salina. Perquirere , n. 5. 2008.

[2] BASER, K. Husnu Can. Biological and Pharmacological Activities of Carvacrol and Carvacrol Bearing Essential Oils. Current Pharmaceutical Design, Eskisehir, v. 14, n. 29, p. 3106-3120, jan. 2008.

[3] CANSIAN, R. L. et al. Toxicity of clove essential oil and its ester eugenyl acetate against Artemia salina. Brazilian Journal Of Biology, [S.L.], v. 77, n. 1, p. 155-161, mar. 2017. FapUNIFESP (SciELO). http://dx.doi.org/10.1590/1519-6984.12215.

[4] DOLABELLA, M. E. Triagem in vitro para a atividade antitumoral e anti-T. cruzi de extratos vegetais, produtos naturais e sintéticos. 1997. 128 f. Dissertação (Mestrado) - Curso de Ciências Biológicas, Universidade Federal de Minas Gerais, Belo Horizonte, 1997.

[5] FERREIRA, Luis E. et al. Thymus vulgaris L. essential oil and its main component thymol: anthelmintic effects against haemonchus contortus from sheep. Veterinary Parasitology, [S.L.], v. 228, p. 70-76, set. 2016. Elsevier BV. http://dx.doi.org/10.1016/j.vetpar.2016.08.011.

[6] FERREIRA, Vitor F.; PINTO, Angelo C.. A fitoterapia no mundo atual. Química Nova, [S.L.], v. 33, n. 9, p. 18291829, 2010. FapUNIFESP (SciELO). http://dx.doi.org/10.1590/s0100-40422010000900001.

[7] GOBBO-NETO, Leonardo; LOPES, Norberto P.. Plantas medicinais: Fatores de influência no conteúdo de metabólitos secundário. Química Nova, Ribeirão Preto, v. 30, n. 2, p. 374-381, mar. 2007.

[8] GURIB-FAKIM, Ameenah. Medicinal plants: traditions of yesterday and drugs of tomorrow. Molecular Aspects Of Medicine, [S.L.], v. 27, n. 1, p. 1-93, fev. 2006. Elsevier BV. http://dx.doi.org/10.1016/j.mam.2005.07.008.

[9] LAZAREVIĆ, Jelica et al. Toxic, Oviposition Deterrent and Oxidative Stress Effects of Thymus vulgaris Essential Oil against Acanthoscelides obtectus. Insects, [S.L.], v. 11, n. 9, p. 563-582, 24 ago. 2020. MDPI AG. http://dx.doi.org/10.3390/insects11090563.

[10] McLAUGHLIN, J. L. Crown gall tumours on potato discs and brine shrimp lethality: two simple bioassays for higher plant screening and fraction. In: Dey PM, Harbone JB (ed.) Methods in plant biochemistry, New York: Academic Press, p.1-32, 1991. 
[11] MENEZES, Mariana Santos. Caracterização química e efeito do óleo essencial de Lippia gracilis e seus constituintes majoritários sobre Aceria guerreronis (Acari: Eriophyidae). 2016. 38 f. Dissertação (Doutorado) - Curso de Agricultura e Biodiversidade, Universidade Federal de Sergipe, São Cristóvão, 2016.

[12] MEYER, B. et al. Brine Shrimp: a convenient general bioassay for active plant constituents. Planta Medica, [S.L.], v. 45, n. 05, p. 31-34, maio 1982. Georg Thieme Verlag KG. http://dx.doi.org/10.1055/s-2007-971236.

[13] Ministério da Saúde: Agência Nacional de Vigilância Sanitária. Resolução - RDC no 10, de 09 de março, Brasília, 2010. Disponível em: http://bvsms.saude.gov.br/bvs/saudelegis/anvisa/2010/res0010_09_03_2010.html

[14] NIKOLIĆ, Miloš et al. Chemical composition, antimicrobial, antioxidant and antitumor activity of Thymus serpyllum L., Thymus algeriensis Boiss. and Reut and Thymus vulgaris L. essential oils. Industrial Crops And Products, [S.L.], v. 52, p. 183-190, jan. 2014. Elsevier BV. http://dx.doi.org/10.1016/j.indcrop.2013.10.006.

[15] Organização Mundial da Saúde (OMS). Alma-Ata 1978 - Cuidados primários de saúde. Relatório da conferência internacional sobre cuidados primários de saúde. Brasília: Organização Mundial da Saúde/Fundo das Nações Unidas para a Infância; 1979.

[16] ROMERO, Adriano Lopes et al. Atividade do Óleo Essencial de Tomilho (Thymus vulgaris L.) Contra Fungos Fitopatogênicos. Unopar Científica. Ciências Biológicas e da Saúde, [S.I.], v. 4, n. 11, p. 8-15, jan. 2009.

[17] VEIGA JUNIOR, Valdir F.; PINTO, Angelo C.; MACIEL, Maria Aparecida M.. Plantas Medicinais: Cura Segura? Química Nova, [S.I.], v. 28, n. 3, p. 519-528, maio 2004. 


\section{Capítulo 11}

\section{Avaliação do consumo e qualidade de produtos lácteos da alimentação escolar de Jupiá - SC}

\section{Daniela Paula Scanagatta \\ Karine Gabriel \\ Fabiane Picinin de Castro Cislaghi \\ Andréa Cátia Leal Badaró}

Resumo: A alimentação escolar faz parte de um programa governamental, cujo objetivo é contribuir para o crescimento e desenvolvimento dos alunos através da formação de hábitos alimentares saudáveis. 0 objetivo deste trabalho foi avaliar o consumo e os parâmetros de qualidade de produtos lácteos oferecidos na alimentação escolar do município de Jupiá/SC. Os resultados apontaram para a falta de padronização durante o processo de produção, isso em função da variabilidade entre os resultados, alguns deles, fora dos padrões legais. Com relação à preferência dos alunos pelos produtos lácteos, verificou-se que o mais consumido foi o iogurte, e o menos consumido, o queijo. De maneira geral, os alunos gostam da alimentação oferecida pela escola, porém, é necessário incentivar os alunos a consumirem estes alimentos. Nesse sentido, devem-se desenvolver atividades voltadas à educação nutricional e a criação de estratégias para melhorar a aceitação destes e de outros alimentos no ambiente escolar.

Palavras-Chave: Produtos Lácteos. Alimentação Escolar. Qualidade dos Alimentos. Aceitação do consumo. 


\section{INTRODUÇÃO}

Os hábitos alimentares são formados na infância, e tendem a se manter ao longo da vida. Esses hábitos são determinados por fatores fisiológicos, socioculturais e psicológicos. A alimentação escolar é importante para a criança, pois esta encontra-se em fase de crescimento, e portanto, as exigências nutricionais devem ser atendidas em todos os parâmetros (energético, proteico, lipídico, vitamínico, minerais e de fibras) (FLÁVIO et al., 2002).

Concomitante a isto, o controle de qualidade do leite e dos produtos lácteos é importante para garantir a saúde da população. A qualidade pode ser determinada através de análises físicas, químicas, microbiológicas e sensoriais. É essencial conhecer as características microbiológicas e a composição química do leite, pois estas irão influenciar na qualidade dos produtos lácteos.

Sabendo-se da importância que a alimentação tem para o desenvolvimento e crescimento das crianças, que a escola desenvolve, juntamente com a família, um papel fundamental na formação de hábitos alimentares do indivíduo e o papel que o leite e seus derivados representam na nutrição infantil (OLIVEIRA e VASSIMO, 2012), este estudo teve como objetivo analisar os parâmetros de qualidade e os hábitos de consumo dos produtos lácteos oferecidos na alimentação escolar de Jupiá-SC.

\section{MATERIAL E MÉTODOS}

As amostras de iogurte, leite pasteurizado e queijo, oferecidas na alimentação escolar foram coletadas em uma escola municipal da cidade de Jupiá - SC, durante os meses de abril e maio de 2014. Nas amostras de leite pasteurizado foram realizadas análises de Coliformes a 45으 e Salmonella ssp., gordura, extrato seco desengordurado (ESD), densidade, ponto de congelamento, proteína, porcentagem de água adicionada intencionalmente, teor de acidez titulável, fosfatase alcalina e peroxidase. Nas amostras de iogurte foram realizadas análises de Coliformes a $45^{\circ} \mathrm{C}$, proteína e gordura. Nas amostras de queijo prato foram analisadas quanto presença de Salmonella ssp., Coliformes a $45^{\circ} \mathrm{C}$ e Staphylococcus coagulase positiva, umidade e gordura. As metodologias de coleta e análises foram baseadas nas referências do Ministério da Agricultura, Pecuária e Abastecimento (BRASIL, 2003, 2006) e do Instituto Adolf Lutz (IAL, 2008).

Foi ainda aplicado um questionário para que as crianças, as quais os pais assinaram o Termo de Consentimento Livre e Esclarecimento autorizando a participação dos filhos, para se obter dados quanto aos hábitos de consumo e aceitação da alimentação escolar oferecida. Os dados foram tabulados em planilhas do Excel 2013 (Office Microsoft ${ }^{\circledR}$ ), para facilitar a interpretação e apresentação dos resultados.

\section{RESULTADOS E DISCUSSÃO}

\subsection{PARÂMETROS DE QUALIDADE DOS PRODUTOS LÁCTEOS}

Os resultados obtidos no estudo permitiu verificar que os índices crioscópicos das amostras estão acima do estabelecido pela legislação (BRASIL, 2011), que estabelece valor de $-0,512^{\circ} \mathrm{C}$ a $-0,531^{\circ} \mathrm{O}$. A crioscopia varia de acordo com a época do ano, região, raça e alimentação do animal. 0 índice crioscópico do leite fraudado com água aproxima-se de $0^{\circ} \mathrm{C}$, e quando há adulteração por adição de sólidos, este índice tende a ultrapassar o valor de $-0,531^{\circ} \mathrm{C}$, visto que o leite geralmente é adicionado de substâncias alcalinas, cloretos, sacarose, etc.

Verificou-se que a amostra "A" apresentou Extrato Seco Desengordurado (ESD) de 8,19g/100g, estando abaixo dos padrões da legislação (BRASIL, 2011), que estabelece como valor mínimo 8,4. 0 ESD corresponde ao percentual de nutrientes do leite, exceto a água e a gordura. Esta determinação é importante para avaliar a composição do leite, e é utilizado para estimar o rendimento obtido na indústria de produtos lácteos. A presença de mastite subclínica ou altas contagens bacterianas no animal podem resultar na diminuição da síntese de lactose no leite, e consequentemente na diminuição de ESD. Além disso, o tipo de alimentação que é fornecida aos animais e ações fraudulentas, como a adição de água, também influenciam na redução destes parâmetros.

Constatou-se que a amostra "A" também apresentou teor de proteína de 2,67g/100g, também abaixo do exigido pela IN 62/2011 (BRASIL, 2011), o que inclusive pode ter refletido no valor de ESD, já que a proteína é um dos componentes do ESD do leite. Os resultados quanto a densidade, acidez, fosfatase alcalina e peroxidase encontravam-se dentro dos padrões de qualidade normais. 
Quanto ao queijo prato, observou-se que os resultados observados nas amostras A e B apresentaram teor de gordura abaixo do padrão preconizado pela legislação para este tipo de queijo (BRASIL, 1996). Este parâmetro é importante para o queijo, pois além de contribuírem para a cremosidade do produto, alguns ácidos graxos livres, formados durante o período de maturação, auxiliam na formação de aroma deste produto. A umidade variou de 23,65 a 26,49\%, também abaixo dos valores preconizados para este tipo de produto. A análise de umidade é uma das mais importantes a serem realizadas em alimentos, visto que esta indica qualidade, composição e estabilidade, podendo influenciar no processamento e estocagem dos produtos.

As amostras de iogurtes foram elaboradas com leite contendo seu conteúdo integral de gordura, porém verificou-se que as amostras A e B encontram-se abaixo do padrão para este tipo de produto. A redução do teor de gordura nestes produtos é bem vista, em função dos benefícios a saúde, principalmente pelos consumidores serem crianças, porém, é necessário que o produto seja padronizado.

Com relação ao parâmetro proteína, observou-se que as três amostras de iogurte avaliadas apresentaram valores abaixo do padrão. A baixa quantidade de proteína no iogurte indica baixa qualidade do leite utilizado, pois as proteínas do leite são mantidas durante a produção de iogurte. Ao analisar a acidez, verificou-se que as amostras A e B apresentaram valores dentro dos limites previstos pela legislação, e a amostra $\mathrm{C}$ observou-se resultado abaixo do limite. Baixos valores de acidez em iogurtes pode favorecer o desenvolvimento de microrganismos indesejáveis, dentre eles, coliformes e até mesmo, patogênicos. Por outro lado, a acidez elevada poderá alterar as características sensoriais do iogurte, cau sando rejeição pelo consumidor.

As médias Dos resultados obtidos nas análises microbiológicas das amostras de leite pasteurizado, queijo e iogurte encontram-se na tabela 1.

Tabela 1 - Parâmetros microbiológicos das amostras de leite pasteurizado, queijo e iogurte.

\begin{tabular}{|c|c|c|c|c|}
\hline Produto & Amostras & $\begin{array}{l}\text { Coliformes } 45^{\circ} \mathrm{C} \text { (NMPa. } \\
\left.\qquad \mathrm{g}^{-1} \text { ou mL } \mathrm{mL}^{-1}\right)\end{array}$ & $\begin{array}{l}\text { Staphylococcus coag. } \\
\text { Positiva (UFC } \text { g }^{-1} \text { ou mL- } \\
\text { 1) }\end{array}$ & $\begin{array}{l}\text { Salmonella spp. (em } \\
25 \mathrm{~g} \text { ou } \mathrm{mL} \text { ) }\end{array}$ \\
\hline $\begin{array}{c}\text { Leite pasteurizado } \\
\text { Padrão }\end{array}$ & $\begin{array}{l}\text { A } \\
\text { B } \\
\text { C }\end{array}$ & $\begin{array}{c}7,9 \\
1,0 \\
<3,0 \\
4 \text { NMP.g }{ }^{-1} \text { ou } \mathrm{mL}^{-1}\end{array}$ & $\begin{array}{r}\mathrm{NA}^{\mathrm{c}} \\
\mathrm{NA} \\
\mathrm{NA} \\
-\end{array}$ & $\begin{array}{r}\text { Aus } \\
\text { Aus } \\
\text { Aus } \\
\text { Aus }\end{array}$ \\
\hline $\begin{array}{l}\text { Queijo prato } \\
\text { Padrão }\end{array}$ & $\begin{array}{l}\text { A } \\
\text { B } \\
\text { C }\end{array}$ & $\begin{array}{c}2,0 \times 10^{1} \\
<3,0 \\
3,0 \\
10^{3} \text { NMP.g }{ }^{-1}{\text { ou } \mathrm{mL}^{-1}}^{-1}\end{array}$ & $\begin{array}{c}<1 \times 10^{1} \\
<1 \times 10^{1} \\
<1 \times 10^{1} \\
10^{3} \text { NMP.g- }^{-1}\end{array}$ & $\begin{array}{l}\text { Aus } \\
\text { Aus } \\
\text { Aus } \\
\text { Aus }\end{array}$ \\
\hline $\begin{array}{l}\text { Iogurte } \\
\text { Padrão }\end{array}$ & $\begin{array}{l}\text { A } \\
\text { B } \\
\text { C }\end{array}$ & $\begin{array}{c}<3,0 \\
<3,0 \\
<3,0 \\
10 \text { NMP.g } \text { g }^{-1} \text { ou }^{-1}\end{array}$ & $\begin{array}{l}\text { NA } \\
\text { NA } \\
\text { NA }\end{array}$ & $\begin{array}{l}\text { NA } \\
\text { NA } \\
\text { NA }\end{array}$ \\
\hline
\end{tabular}

Notas: (a) Número Mais Provável; (b) Unidades Formadoras de Colônia; (c) Não avaliado; (d) Ausência

A RDC nํ․ 12/2001 estabelece a contagem de coliformes a 45ํㅡ, em leite pasteurizado, de no máximo 4 NMP.mL ${ }^{-1}$ (BRASIL, 2001). A amostra A apresentou resultado acima do padrão na análise de coliformes a $45^{\circ} \mathrm{C}$, indicando que houve falhas no processamento térmico ou recontaminação pós-processamento através de equipamentos sujos ou devido à manipulação inadequada. Os coliformes são destruídos no processo de pasteurização, sua presença em leite pasteurizado indica a necessidade de um maior controle de tempo e temperatura do pasteurizador, ou cuidados para evitar a recontaminação após o tratamento térmico. Todos os demais parâmetros microbiológicos avaliados nas amostras de leite, queijo e iogurte atenderam aos padrões da legislação em vigor.

\subsection{HÁBITOS DE CONSUMO DA ALIMENTAÇÃO ESCOLAR}

Dos 90 alunos participantes da pesquisa, 38\% eram do sexo feminino e 52\% do sexo masculino, com idades médias de 9,2 anos. Destes, 24\% eram da terceira série, 37\% da quarta série e 29\% da quinta série. Com relação ao hábito de consumir a alimentação oferecida pela escola, constatou-se que $92 \%$ dos alunos entrevistados afirmaram ter este hábito, um resultado considerado satisfatório em função destes alimentos serem ricos em nutrientes importantes para o crescimento e desenvolvimento das crianças. 
A maior parte dos alunos entrevistos (42\%), avaliou a alimentação geral oferecida na escola como boa, $39 \%$ dos alunos avaliou como ótima, 16\% como nenhuma das opções e 3\% como ruim, ou seja, de maneira geral os alunos gostam das preparações oferecidas no lanche da escola.

Entre os produtos lácteos, o mais consumido é o iogurte (58\%) seguido pelo leite (56\%) e pelo queijo (46\%). Com relação a frequência, 52\% dos alunos entrevistados afirmaram consumir os produtos lácteos as vezes, $32 \%$ sempre e $1 \%$ nunca. Considerando a importância do consumo de lácteos na alimentação das crianças, percebe-se que a frequência do consumo destes produtos é baixa, pois 32\% dos alunos entrevistados afirmaram consumir estes produtos sempre que são oferecidos.

Dentre os produtos lácteos oferecidos pela escola, verificou-se que o queijo é o que 34\% das crianças entrevistada menos gostam, seguido do leite e iogurte, ambos com 30\%. Observou-se ainda que a maioria dos alunos entrevistados classificaram os três produtos na opção "bom", sendo o iogurte para 54\% deles, o leite $44 \%$ e para o queijo $46 \%$.

Antagonicamente, apesar da maioria dos alunos terem classificado estes produtos como "bom", o consumo ainda é baixo. Este fato pode estar relacionado com a forma como estes produtos são oferecidos na alimentação, por exemplo, o queijo é oferecido juntamente com macarrão, polenta e com pão e mortadela, se o aluno não gostar da preparação em si, vai acabar assinalando a opção que não consome ou não gosta de queijo. Assim poderá ter ocorrido para o leite, que é servido com achocolatado e biscoitos. No caso do iogurte, a criança pode não gostar do sabor que é oferecido e assim, assinalar que não consome ou consome somente às vezes o produto.

\section{CONCLUSÕES}

A pesquisa permitiu avaliar a qualidade microbiológica e físico-química dos produtos lácteos da alimentação escolar do município em questão. Através dos resultados encontrados nas análises físicoquímicas dos três produtos oferecidos na alimentação escolar, observou-se que há falta de padronização durante o processo de produção, isso em função da variabilidade entre os resultados, alguns deles, fora dos padrões legais indicando a necessidade maior atenção quanto ao monitoramento principalmente na qualidade da matéria prima, ou seja, o leite.

Com relação à adesão e preferência dos alunos pelos produtos lácteos, verificou-se que, de maneira geral, os alunos gostam da alimentação oferecida pela escola. Destaca-se a necessidade de criar estratégicas para agradar aos alunos e assim aumentar o consumo de produtos mais saudáveis, como o leite e seus derivados. 0 incentivo à inclusão destes alimentos mesmo nas refeições diárias poderia ocorrer por meio de educação nutricional, uma das grandes estratégias para trabalhar a aceitação.

\section{AGRADECIMENTOS}

As autoras agradecem à UTFPR-Francisco Beltrão-PR e à Secretaria de Educação da Prefeitura de Jupiá-SC pelo apoio logístico, ajuda financeira e por permitirem a realização da pesquisa.

\section{REFERÊNCIAS}

[1] BRASIL. Agência Nacional de Vigilância Sanitária. Resolução de Diretoria Colegiada - RDC no. 12, de 2 de janeiro de 2001. Regulamento técnico que dispõe sobre Padrões Microbiológicos Sanitários para Alimentos. Diário Oficial da União, Brasília, 2001.

[2] BRASIL. Ministério da Agricultura, Pecuária e Abastecimento. Instrução Normativa no 62 de 26/08/2003. Métodos analíticos oficiais para análise microbiológica para controle de produtos de origem animal e água. Diário Oficial da União, Brasília, 2003.

[3] BRASIL. Ministério da Agricultura, Pecuária e Abastecimento. Instrução Normativa no 68, de 12/12/06. Estabelece métodos analíticos físico - químicos oficiais para leite e produtos lácteos. Diário Oficial da União, Brasília, 2006.

[4] BRASIL. Ministério da Agricultura, Pecuária e Abastecimento. Instrução Normativa no 62, de 29/12/2011. Aprovar o Regulamento Técnico de Produção, Identidade e Qualidade do Leite. Diário Oficial da União, Brasília, 2011.

[5] BRASIL. Ministério da Agricultura, Pecuária e Abastecimento. Regulamentos Técnicos de Identidade e Qualidade dos Produtos Lácteos. Portaria n 146, de 07/03/1996. Diário Oficial da União, Brasília, 1996. 
[6] FLÁVIO, E.F.; BARCELOS, M.F.P.; LIMA, A.L. Avaliação química e aceitação da merenda escolar de um a escola estadual de Lavras - MG. Cien. Agrotec. Lavras, v. 28, n. 4, ago. 2004.

[7] IAL. INSTITUTO ADOLFO LUTZ. Normas Analíticas do Instituto Adolfo Lutz. Métodos químicos e físicos para análise de alimentos. 4. ed. São Paulo: IMESP, 2008.

[8] OLIVEIRA, M.C.; VASSIMO, H.S. Programa Nacional de Alimentação Escolar e sua aceitação pelos alunos: uma revisão sistemática. São Paulo, 2012. 


\section{Capítulo 12}

\section{Avaliação da eficiência da implantação de Procedimento Operacional Padronizado (POP) em uma Unidade de Alimentação e Nutrição Institucional}

\section{Elaine Alves dos Santos}

Deborah Santesso Bonnas

Resumo: 0 objetivo do presente estudo foi avaliar a eficiência da implantação de Procedimento Operacional Padronizado referente à higienização de hortifrutícolas em uma Unidade de Alimentação e Nutrição Institucional. Para a implantação do procedimento foram utilizados dois tratamentos, (Sanitização 1 e 2) e dois tempos de contato (Tempo 0 e 10 min.). Com base nos resultados obtidos foi possível perceber que o procedimento realizado de maneira empírica pelos colaboradores da UAN (Sanitização1) não apresentou ao final dos tempos estudados quantidade significativa de cloro residual. As concentrações de cloro residual livre para a Sanitização 2 em relação aos dois tempos estudados encontram-se de acordo com o preconizado pela literatura. Conclui-se que a implantação do POP de higienização das hortifrutícolas foi satisfatória, evidenciando a importância deste para a produção de alimentos seguros bem como da adoção de práticas corretas no manuseio dos alimentos com vistas a assegurar à saúde dos consumidores.

Palavras-Chave: Procedimento Operacional Padronizado (POP); hipoclorito de sódio; cloro residual livre. 


\section{INTRODUÇÃO}

A ocorrência de Doenças Transmitidas pelos alimentos são um problema de saúde pública e está diretamente relacionada aos procedimentos de higienização dos alimentos, dos utensílios e equipamentos bem como à higiene dos manipuladores, quando executados de maneira insatisfatória, devido à falta de informação ou da não implantação de Boas Práticas de Fabricação nos estabelecimentos produtores e industrializadores de alimentos.

A correta higienização de instalações, equipamentos, móveis e utensílios minimiza o risco de ocorrência de contaminações veiculadas por essas superfícies na indústria de alimentos (FLEETWOOD et al., 2019).

Os Procedimentos Operacionais Padronizados (POPS) são documentos de registro que devem conter as instruções sequenciais das operações e a frequência de execução, especificando o nome, cargo e função dos responsáveis pelas atividades. Devem ser aprovados, datados e assinados pelo responsável do estabelecimento (BRASIL, 2004a).

As condutas e critérios descritos nos POPS configuram os procedimentos básicos que devem ser seguidos para o cumprimento do controle higiênico-sanitário (BRASIL, 2002).

O cloro, principalmente o hipoclorito de sódio (água sanitária), é o sanitizante mais utilizado no Brasil por possuir amplo conhecimento popular e é o único permitido pela legislação (NASCIMENTO, 2010).

Os compostos à base de cloro são biocidas de amplo espectro de ação, que reagem com as proteínas da membrana das células microbianas, interferindo no transporte de nutrientes e promovendo à perda de componentes celulares (VANETTI, 2000).

0 hipoclorito de sódio é encontrado na concentração de 2,0 a 2,5\% p/p em água sanitária. Por ser um produto de baixo custo, eficiente e de fácil acesso, a água sanitária tem sido utilizada como sanitizante em hortifrutícolas.

O objetivo do presente estudo foi avaliar a eficiência da implantação de Procedimento Operacional Padronizado referente à higienização de hortifrutícolas em uma Unidade de Alimentação e Nutrição Institucional (UAN), contribuindo assim para a produção de alimentos com qualidade sanitária satisfatória.

\section{MATERIAL E MÉTODOS}

O trabalho foi conduzido na Unidade de Alimentação e Nutrição (UAN) do Instituto Federal de Educação Ciência e Tecnologia do Triangulo Mineiro - Campus Uberlândia (IFTM). Alimentam-se na referida UAN 500 pessoas em média diariamente, evidenciando-se a importância da adoção de práticas corretas no manuseio dos alimentos com vistas a assegurar à saúde dos consumidores. O Procedimento Operacional Padronizado (POP) referente à Higienização das Hortifrutícolas consumidas na referida UAN foi elaborado e implantado, compreendendo as seguintes etapas:

1. Selecionar e desprezar partes não aproveitáveis;

2. Fazer pré-lavagem em água potável corrente folha a folha ou um a um para remover excesso de terra, larvas, etc;

3. Sanitizar por 15 minutos em solução clorada ( $80 \mathrm{ml}$ de água sanitária 2,5\% para 10 litros de água);

4. $\quad$ Enxaguar em água potável corrente;

5. Deixar secar naturalmente, mantendo sob refrigeração e em recipiente limpo e adequado até o momento de servir.

Para a implantação do referido procedimento foram utilizados dois tratamentos, (Sanitização 1 e 2) e dois tempos de contato (Tempo 0 e $10 \mathrm{~min}$.):

Sanitização 1: A solução sanitizante foi preparada pelos colaboradores da UAN de maneira empírica, formato este que os mesmos julgavam correto, sem aferição exata da quantidade de água e Hipoclorito de sódio 2,5\% utilizados. Após preparo, coletou-se $100 \mathrm{ml}$ da solução (Tempo 0 min.) através da utilização de sacos de coleta. Posteriormente foram mergulhadas na referida solução sanitizante dez unidades de cenoura previamente enxaguadas com água corrente e fixado o tempo de contato de 10 minutos. Decorrido este tempo, coletou-se $100 \mathrm{ml}$ da solução (Tempo $10 \mathrm{~min}$.). 
Sanitização 2: 0 preparo da solução sanitizante foi realizado conforme instrução contida no POP descrito anteriormente, utilizando-se balde graduado e proveta para padronização da quantidade de água e hipoclorito, respectivamente. Após preparo, coletou-se $100 \mathrm{ml}$ da solução (Tempo $0 \mathrm{~min}$.) através da utilização de sacos de coleta. Posteriormente foram mergulhadas na referida solução sanitizante dez unidades de cenoura previamente enxaguadas com água corrente e fixado o tempo de contato de 10 minutos. Decorrido este tempo, coletou-se $100 \mathrm{ml}$ da solução (Tempo $10 \mathrm{~min}$.).

Foi determinado o percentual de cloro residual livre presente nas soluções sanitizantes correspondendo aos dois tratamentos (Sanitização 1 e 2) e seus referidos tempos de contato, de acordo com metodologia descrita por Macêdo (2005). As amostras referidas soluções foram transportadas em caixas isotérmicas contendo gelo até o Laboratório de Análise Físico-química do IFTM- Campus Uberlândia. As análises foram realizadas em triplicata, correspondendo a três amostras por tratamento para cada tempo estudado, totalizando 36 parcelas experimentais. As médias obtidas, quando apresentaram diferença significativa pelo teste de $\mathrm{F}$, foram comparadas através do teste de Scott Knott $(\mathrm{p}<0,05)$, utilizando o programa computacional sistema para Análise de Variância SISVAR (FERREIRA, 2003).

\section{RESULTADOS E DISCUSSÃO}

Os resultados das determinações do cloro residual livre dos tratamentos deste estudo (Sanitização 1 e 2) estão expressos na Tabela 1.

Tabela 1- Cloro residual livre das Soluções Sanitizantes preparadas em função dos tempos de contato estudados.

\begin{tabular}{|c|c|c|}
\hline & Sanitização $1\left(\mathrm{MG} \mathrm{Cl}_{2} / \mathrm{L}\right)$ & Sanitização $2\left(\mathrm{MG} \mathrm{Cl}_{2} / \mathrm{L}\right)$ \\
\hline T 0 & $28,5350 \mathrm{a}$ & $174,7700 \mathrm{c}$ \\
\hline T 10 & $28,2750 \mathrm{a}$ & $170,4460 \mathrm{~b}$ \\
\hline
\end{tabular}

Médias seguidas de mesma letra minúscula nas colunas não diferem entre si pelo teste de Scott Knott $(\mathrm{p}<0,05)$.

Para a Sanitização 1, pode-se observar que as concentrações de cloro residual livre não diferiram entre si em função do tempo de contato com o alimento. Para a Sanitização 2 houve diferença significativa em função do tempo e a concentração de cloro residual no tempo 10 minutos foi menor quando comparada com a média do tempo 0 minutos. Isto pode ser justificado pela propriedade volátil que o hipoclorito de sódio possui, bem como pela presença eventual de resíduos de matéria orgânica, que prejudicam a ação deste sanitizante.

Atualmente, o cloro é o agente sanitizante mais utilizado no Brasil, particularmente o hipoclorito de sódio, em função do custo baixo. A recomendação de uso estabelecida pela legislação é 100-250 ppm, com tempo de contato de 15 minutos (RODRIGUES et al., 2011). Fontana (2006), recomenda que os alimentos permaneçam 15 minutos em soluções de hipoclorito de 50 a 200 ppm, obtendo-se efeitos sanitizantes para o grupo coliformes. A Agência Nacional de Vigilância Sanitária recomenda, em cartilha para manipuladores de alimentos (BRASIL, 2004b), que, após lavagem em água corrente, as folhas de alfaces permaneçam imersas em solução de água clorada a $200 \mathrm{ppm}$ por 10 minutos para que possam ser consumidas com segurança, sendo esta concentração efetiva na destruição de células vegetativas de bactérias.

Com base nos resultados obtidos foi possível perceber que o procedimento realizado de maneira empírica pelos colaboradores da UAN (Sanitização1) não apresentou ao final dos dois tempos estudados quantidade significativa de cloro residual sendo este ineficiente na redução de populações microbianas possivelmente presentes na superfície dos alimentos em questão, podendo culminar na produção de hortifrutícolas contaminadas, representado assim risco à saúde do consumidor.

As concentrações de cloro residual livre para a Sanitização 2 em relação aos dois tempos estudados encontram-se de acordo com o preconizado pelos autores citados, demonstrando que o Procedimento Operacional Padronizado foi implantado de maneira satisfatória, contribuindo assim para a produção de hortifrutícolas inócuas à saúde dos consumidores.

Vale ressaltar que a padronização dos POPs e execução do mesmo de acordo com as instruções descritas, respeitando os tempos de contato e concentrações adequadas, permite o alcanço de resultados satisfatórios, com vistas a atender os requisitos de Boas Práticas de Fabricação dos alimentos. 
Em um processo de desinfecção eficaz deve-se levar em consideração alguns fatores importantes como concentração e tempo de contato do produto, carga microbiana inicial, tipo de microrganismos e ainda a presença de matéria-orgânica (KUAYE, 2017).

\section{CONCLUSÃO}

De acordo com os resultados obtidos no presente estudo conclui-se que a implantação do Procedimento Operacional Padronizado para a higienização das hortifrutícolas foi satisfatória, evidenciando a importância destas ferramentas para a produção de alimentos seguros bem como da adoção de práticas corretas no manuseio dos alimentos com vistas a assegurar à saúde dos consumidores.

\section{REFERÊNCIAS}

[1] BRASIL, Ministério da Saúde, Agência nacional de Vigilância Sanitária. Resolução RDC n 275, de 21 de Outubro de 2002. Dispõe sobre o Regulamento Técnico de Procedimentos Operacionais Padronizados aplicados aos Estabelecimentos Produtores/Industrializadores de Alimentos e a Lista de Verificação das Boas Práticas de Fabricação em Estabelecimentos Produtores/Industrializadores de Alimentos. Diário Oficial da União; Brasília, DF, 23 de Outubro de 2002, seção 1, p. 126.

[2] BRASIL. Ministério da Saúde. Agência Nacional de Vigilância Sanitária. Resolução RDC nº. 216, de 15 de setembro de 2004a. Dispõe sobre regulamento técnico de boas praticas para serviços de alimentação. Diário Oficial da União, Brasília, DF, 16 de set. de 2004, Seção 1, p. 25.

[3] BRASIL, Ministério da Saúde. Agência Nacional de Vigilância Sanitária (Anvisa). Resolução RDC no 216, de 15 de setembro de 2004b. Dispõe sobre o Regulamento Técnico de Boas Práticas para Serviços de Alimentação. Cartilha. Diário Oficial da União. Brasília, DF, 16 set 2004.

[4] FERREIRA, D. F. Programa Sisvar.exe: sistema de análise de variância. Versão 3.04. Lavras: UFLA, 2003.

[5] FLEETWOOD et al. As clean as they look? Food hygiene inspection scores, microbiological contaminatios, and foorborne illness. Food Control, v. 96, p. 76-86, 2019.

[6] FONTANA, N. Atividade antimicrobiana de desinfetantes utilizados na sanitização de alface. [trabalho de conclusão de curso]. Santa Maria: Centro Universitário Franciscano/Unifra, 2006.

[7] KUAYE, A. Y. Limpeza e sanitização na indústria de alimentos. 4ํㅡㄹ ed. Brasil: Atheneu, 2017. 324 p.

[8] MACÊDO, J. A. B. Águas e águas. São Paulo: Varela, 2005. 505 p.

[9] NASCIMENTO M.S, SILVA, N. Tratamentos químicos na sanitização de morango (Fragaria vesca L.). Brazillian Journal Food Technology. v. 13, n.1, 2010.

[10] RODRIGUES, D. G., DA SILVA, N. B. M., REZENDE, C., JACOBUCCI, H. B., e FONTANA, E. A. Avaliação de dois métodos de higienização alimentar. Saúde e Pesquisa, v. 4, n. 3, 2011.

[11] VANETTI, M. C. D. Controle microbiológico e higiene no processamento mínimo. In: ENCONTRO NACIONAL SOBRE PROCESSAMENTO MÍNIMO DE FRUTAS E HORTALIÇAS, 2., 2000, Viçosa. Palestras... Viçosa: UFV, 2000. p.4451. 


\section{Capítulo 13}

\section{Cinética de secagem da curcuma (Curcuma longa L.)}

\section{Ana Teresa Rodrigues França \\ Barbara Daniele Almeida Porciuncula}

Resumo: A cúrcuma é um rizoma pertencente à família Zingiberaceae, a mesma do gengibre. É uma planta condimentar originada do sudeste da Ásia e para utilização da cúrcuma na área alimentícia os rizomas depois de secos são moídos e transformados em pó. A secagem é um dos processos mais tradicionais utilizados para conservação de alimentos. Neste contexto, o presente trabalho tem como objetivo avaliar diferentes temperaturas na cinética de secagem e verificar o ajuste dos modelos matemáticos aos dados experimentais obtidos. Para isso, realizou-se a secagem das fatias de cúrcuma a 50 e $60{ }^{\circ} \mathrm{C}$ em estufa com circulação de ar e verificou-se o comportamento das curvas de secagem por ajuste de modelos empíricos. Pelos resultados obtidos pode-se concluir que a temperatura apresentou influência na cinética e nas taxas de secagem da cúrcuma, uma vez que houve uma redução no tempo para atingir o teor de umidade de equilíbrio, a $50{ }^{\circ} \mathrm{C}$ foi de 400 minutos e a $60 \stackrel{\circ}{\circ} \mathrm{C}$ de 300 minutos. Os modelos que melhor se ajustaram aos dados de secagem da cúrcuma foram o de Midilli e o de Page.

Palavras-chave: Cúrcuma, ajuste matemático, cinética de secagem, Midilli, Page. 


\section{INTRODUÇÃO}

A cúrcuma, Cúrcuma longa L., é um rizoma pertencente à família Zingiberaceae, a mesma do gengibre. É originada do sudeste da Ásia, mais precisamente da Índia e vem sendo cultivada em países tropicais. É uma planta de pequeno porte, composta de um rizoma principal, o qual é arredondado, carnudo e com várias ramificações menores, demora cerca de 10 meses para que o rizoma possa ser colhido. 0 rizoma é a parte da planta mais utilizada, pois, apresenta maior concentração de substâncias condimentares, nutricionais e medicinais (CECílIO FILHO et. al., 2000; VILELA \& ARTUR, 2008).

Na área alimentícia, a cúrcuma é utilizada na confecção de bolos, macarrões, sorvetes, ovos, salgadinhos, carnes, margarinas e mostardas. 0 seu uso vem aumentando, ela representa uma ótima substituta do corante sintético tartrazina que pode causar danos à saúde de crianças, e somando a isso, ela apresenta atividade antimicrobiana, mostrando grande importância na industrialização de alimentos. Para utilização da cúrcuma na área alimentícia os rizomas depois de secos são moídos e transformados em pó, deles são extraídos óleos essenciais, que podem ser utilizados como corantes naturais, antioxidantes e antimicrobianos, devido a presença da curcumina (CECILIO FILHO et al., 2000; MAIA, FERREIRA e ABREU 2004; POLÔNIO, 2009).

Os principais componentes químicos dos rizomas da cúrcuma são os curcuminóides, entre eles estão a curcumina, um pigmento ativo que confere ao rizoma a coloração amarela e que apresenta ação antiinflamatória e antioxidante, e também estão presentes óleos essenciais, como a dehidrotumerona, turmerona e as cetonas aromáticas, que são responsáveis pelas excelentes características sensoriais (ALMEIDA, 2006).

A realização da secagem de alimentos é um dos processos mais tradicionais utilizados para conservação. Tem como vantagens dar maior estabilidade aos componentes aromáticos à temperatura ambiente, proteger contra degradação enzimática e oxidativa, reduzir o peso e o volume, eliminar a necessidade de refrigeração. A retirada de água pode ser realizada através do efeito da temperatura sobre o alimento, envolvendo a transferência de calor e transferência de massa, acompanhado da mudança de fase da água (BARBANTI; MASTROCOLA; PIZZARANI, 1995; GONELLI, 2008; PARK, YADO, BROD, 2001; VILELA E ARTUR, 2008).

A cúrcuma é comumente seca por secagem natural em terreiros sob condições não controladas, sendo esse método de secagem o mais antigo e muito utilizado pela população. É um processo lento, que deve ser conduzido à sombra, em local ventilado, com altas temperaturas e baixa umidade relativa, protegido de poeira e do ataque de insetos e outros animais, e não pode ser controlada; o tempo de secagem de cada alimento vai depender das condições climáticas (CAMACHO et al., 2004; GONELLI, 2008).

Encontrou-se autores que estudaram em seu trabalho a secagem da cúrcuma em diferentes cortes geométricos, diferentes condições de temperatura e diferentes velocidades do ar, Vilela e Artur (2008) relataram que as cinéticas de secagem apresentam a influência da casca, do tipo de corte, da temperatura e da velocidade do ar. Eles consideram que estes parâmetros são de grande importância ao desenvolvimento de novos equipamentos e processos de secagem. Na secagem convectiva, o ar aquecido funciona como agente de secagem passando sobre e/ou através do alimento, evaporando a umidade e a transportando para fora do secador. Neste processo pode se controlar a temperatura e umidade do ar aquecido (PARK, YADO, BROD, 2001). A secagem em estufa é bastante utilizada pelas indústrias, pois, é possível controlar os parâmetros de temperatura, velocidade do ar e umidade relativa e assim obter um produto com características padronizadas. Atualmente, vem sendo estudado uma grande variedade de alimentos, dentre eles a cúrcuma. Os estudos sobre a cinética de secagem da cúrcuma ainda são escassos.

Neste contexto, o presente trabalho tem como objetivo avaliar diferentes temperaturas na cinética de secagem e avaliar o ajuste de modelos matemáticos empíricos aos dados experimentais.

\section{METODOLOGIA}

\subsection{MATÉRIA PRIMA}

A cúrcuma foi obtida no mercado local de Umuarama-PR. Os rizomas foram obtidos de um só produtor e foi observado a cor, o teor de umidade e o conteúdo de sólidos solúveis ( ${ }^{\circ} \mathrm{Brix}$ ) para garantir a padronização da matéria prima. 


\subsection{SECAGEM}

A secagem da cúrcuma foi realizada por convecção forçada em triplicata, utilizando estufa com circulação e renovação de ar (Marconi, MA035). A cúrcuma foi cortada em fatias de $3 \mathrm{~mm}$ de espessura, pesadas em balança semi analítica (Marte, UX420H) e secas a de $50{ }^{\circ} \mathrm{C}$ e $60 \stackrel{\circ}{\circ} \mathrm{C}$. Para realização da cinética de secagem, retirou-se a amostra da estufa para verificação da massa em intervalos de 15 minutos nas 2 primeiras horas, e a cada 30 minutos até peso constante.

\subsection{DETERMINAÇÃO DE UMIDADE}

A umidade foi determinada através do método gravimétrico a $105{ }^{\circ} \mathrm{C}$ (Instituto Adolfo Lutz, 2008) em estufa sem circulação de ar (LOGEN, SP labor 1.1).

\subsection{AJUSTE MATEMÁTICO}

Com o auxílio do software Matlab® modelos matemáticos foram ajustados aos dados experimentais para verificação do comportamento da secagem da cúrcuma. Os modelos ajustados foram os de Midili, Page e Wang e Sing (MIDILLI, KUCUK, YAPART, 2002; YALDIZ, ERTEKI, UZUN, 2001). Os modelos estão numerados e apresentados na Tabela 1.

Tabela 2. Modelos matemáticos

\begin{tabular}{|l|c|}
\multicolumn{1}{c|}{ Modelo } & $\begin{array}{c}\text { Equação } \\
\text { Midilli }\end{array}$ \\
\hline Page & $\mathrm{f}(\mathrm{x})=\mathrm{e}^{\left(-\mathrm{k}^{*} \mathrm{x}^{\mathrm{n}}\right)}+\left(\mathrm{b}^{*} \mathrm{x}\right)$ \\
\hline Wang e Sing & $\mathrm{f}(\mathrm{x})=\mathrm{e}^{-\mathrm{k}^{*} \mathrm{x}^{\mathrm{n}}}$ \\
\hline
\end{tabular}

* $\mathrm{k}$, a, b, n são constantes dos modelos; $\mathrm{x}$ é o tempo de secagem (h).

\section{RESULTADOS E DISCUSSÃO}

A cúrcuma adquirida no comércio local da cidade de Umuarama-PR apresentou umidade $12,71 \mathrm{~kg}$ de água/kg de sólido seco, e 22 ํㅏix de sólido solúveis. 0 teor de umidade encontrado na cúrcuma utilizada no presente trabalho é superior ao encontrado na literatura. Parveen, Kailappan e Dhananchezhiyan (2013) encontraram umidade de 4,11 kg de água/kg de sólido seco e Prasad et al. (2006) encontraram uma umidade de 3,55 kg de água/kg de sólido seco. A diferença nos teores de umidade pode ser explicada pelo local de cultivo e a época de plantio, já que esses são fatores relevantes na composição do rizoma (CECILIO FILHO et. al.,2000). 0 teor de sólidos solúveis não foi encontrado na literatura, porém Cecilio Filho et al. (2000) relata que a cúrcuma apresenta $2 \%$ de açúcares redutores e não redutores, que são constituintes dos sólidos solúveis dos alimentos, valor muito abaixo do encontrado no presente trabalho. Como observado, os teores de umidade e de sólidos solúveis apresentados no presente trabalho são superiores aos encontrados na literatura, isso pode ser explicado pelo grau de maturação que a cúrcuma foi utilizada, ela ainda se encontrava verde, em grau de maturação não ideal para o consumo.

Na Figura 1 estão apresentadas as curvas de cinética de secagem obtida durante a secagem da cúrcuma nas temperaturas de 50 e a $60{ }^{\circ} \mathrm{C}$ e o ajuste do modelo de Midilli aos dados experimentais. 
Figura 1. Cinética de secagem das fatias de cúrcuma em diferentes temperaturas e ajuste do modelo de Midilli aos dados experimentais.

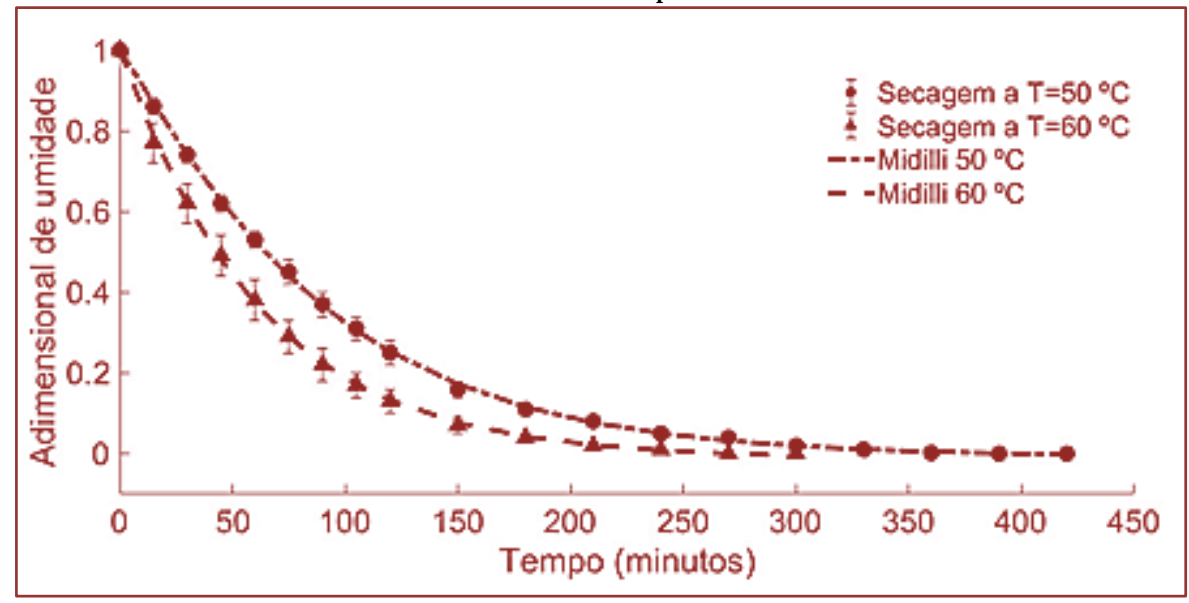

Ao observar os dados apresentados na Figura 1, nota-se que com o passar do tempo o teor de umidade nas amostras diminui. Inicialmente, a superfície da amostra passa a ser aquecida devido ao efeito da temperatura do ar de secagem acarretando no aumento da evaporação da água da superfície da amostra para o ar. Isso ocorre devido à diferença entre as pressões de vapor da superfície do alimento e do ar de secagem, a água presente no interior do alimento difunde para a superfície do mesmo, este fenômeno se propaga até que toda a água livre do alimento seja evaporada (TADINI et al., 2016). No tempo de 150 minutos de secagem observa-se que a umidade das amostras começa a se tornar constante, indicando que está ocorrendo à aproximação da pressão parcial de vapor de água do alimento com a pressão parcial do vapor de água contida no ar, dificultando a saída de água do alimento devido à diminuição do gradiente de umidade entre a umidade do ar e a amostra (FOUST et al., 2012; TADINI et al., 2016). Com o passar do tempo tem-se a igualdade das pressões parciais de vapor de água do alimento e do ar, isso ocorre porque a água que restou no interior do alimento se encontra em equilíbrio com a umidade do ar, resultando em uma isoterma de equilíbrio (FOUST et al., 2012; PARK et al., 2014).

Pode ser observado que para as amostras secas a temperatura de $60{ }^{\circ} \mathrm{C}$ a umidade estabilizou aos 300 minutos de secagem, as amostras secas na temperatura de $50{ }^{\circ} \mathrm{C}$ a umidade se estabilizou aos 400 minutos de secagem. Isso mostra que a temperatura de secagem é uma variável de grande influência no processo. Sendo assim quanto maior a temperatura utilizada mais rápido ocorre o processo de secagem (FELLOWS, 2006; MOCHI, 2005).

Os modelos matemáticos foram ajustados aos dados experimentais obtidos na cinética de secagem a 50 e a $60 \stackrel{\circ}{ } \mathrm{C}$, e a partir disso, obteve-se os parâmetros de ajuste dos modelos aos dados experimentais, os quais estão apresentados na Tabela 2 e os parâmetros estatísticos estão apresentados na Tabela 3.

Tabela 2. Valor das constantes empíricas dos modelos ajustados.

\begin{tabular}{|c|c|c|c|c|c|c|c|}
\hline \multirow{2}{*}{ AMOSTRA } & \multicolumn{3}{|c|}{ MIDILLI } & \multicolumn{2}{|c|}{ PAGE } & \multicolumn{2}{|c|}{ WANG E SING } \\
\hline & $\mathrm{k}$ & B & $\mathrm{N}$ & $\mathrm{K}$ & $\mathrm{n}$ & $\mathrm{a}$ & b \\
\hline $50 \stackrel{\circ}{ } \mathrm{C}$ & 0,0073 & $-1,586.10^{-5}$ & 1,0930 & 0,0070 & 1,1050 & $-0,0072$ & 0,0035 \\
\hline $60 \stackrel{\circ}{ } \mathrm{C}$ & 0,0150 & $-3,822.10^{-5}$ & 1,0210 & 0,0140 & 1,0400 & $-0,0103$ & 0,0049 \\
\hline
\end{tabular}

Tabela 3. Dados do coeficiente de determinação e raiz do erro médio quadrático para os diferentes modelos avaliados.

\begin{tabular}{|c|c|c|c|c|}
\hline \multirow{2}{*}{ Modelo } & \multicolumn{2}{|c|}{$50 \stackrel{\circ}{\circ}$} & \multicolumn{2}{|c|}{$60 \stackrel{\circ}{ } \mathrm{C}$} \\
\hline & $\mathrm{R}^{2}$ & RMSE & $\mathrm{R}^{2}$ & RMSE \\
\hline Midilli & 0,9997 & 0,0058 & 0,9996 & 0,0069 \\
\hline Page & 0,9996 & 0,0063 & 0,9994 & 0,0082 \\
\hline Wang e Sing & 0,9534 & 0,0712 & 0,9336 & 0,0805 \\
\hline
\end{tabular}


O parâmetro k presente nos modelos de Midilli e Page é a constante de secagem e caracteriza o efeito da temperatura sobre o alimento (BABALIS E BELESSIOTIS, 2004). Isto pode ser observado na Tabela 2, em que o aumento da temperatura de secagem acarretou em um aumento no valor da constante $\mathrm{k}$. 0 parâmetro n, apresenta um decréscimo em seu valor com o aumento da temperatura e isso acontece, segundo Simpson et al. (2017), porque o parâmetro n depende da microestrutura do material que é degradada com o aumento da temperatura. Os parâmetros b e a não apresentaram uma constância em seu comportamento. 0 mesmo comportamento entre as constantes empíricas foi relatado por Santos et al. (2013) ao estudar a cinética de secagem de farinha de grãos residuais de urucum e por Prato (2010) ao estudar a influência da secagem sobre compostos medicinais e de pungência do gengibre.

Os parâmetros estatísticos avaliam a capacidade de os modelos utilizados descreverem com fidelidade o processo, os quais são medidos pelo coeficiente de correlação $\left(\mathrm{R}^{2}\right)$ que deve apresentar valores acima de 0,95 e pela raiz de erro médio quadrático (RMSE) que deve apresentar valores inferiores a 0,10 (SILVA et al., 2017; GONÇALVES et al., 2016). Levando isso em consideração, observa-se pelos resultados da Tabela 3, que os modelos de Midilli e de Page, apresentaram um melhor ajuste aos dados experimentais, pois apresentaram o maior valor de $\mathrm{R}^{2}$ e o menor valor de RMSE. Porém, pode-se dizer que o modelo de Midilli representa melhor os dados experimentais por ter menos parâmetros de ajuste do que o modelo de Page. Estes resultados são evidenciados na Figura 1, demonstrando que o modelo de Midilli representa bem a secagem de materiais biológicos. Os modelos de Midilli e de Page também apresentaram bons ajustes a secagem de cenouras segundo Silva et al. (2017) e a secagem do resíduo de manga Tommy Atkins de acordo com André et al. (2014).

A velocidade da secagem nas diferentes temperaturas pode ser melhor observada pela taxa de secagem a qual está apresentada na Figura 2.

Figura 2. Taxa de secagem das fatias de cúrcuma em diferentes temperaturas.

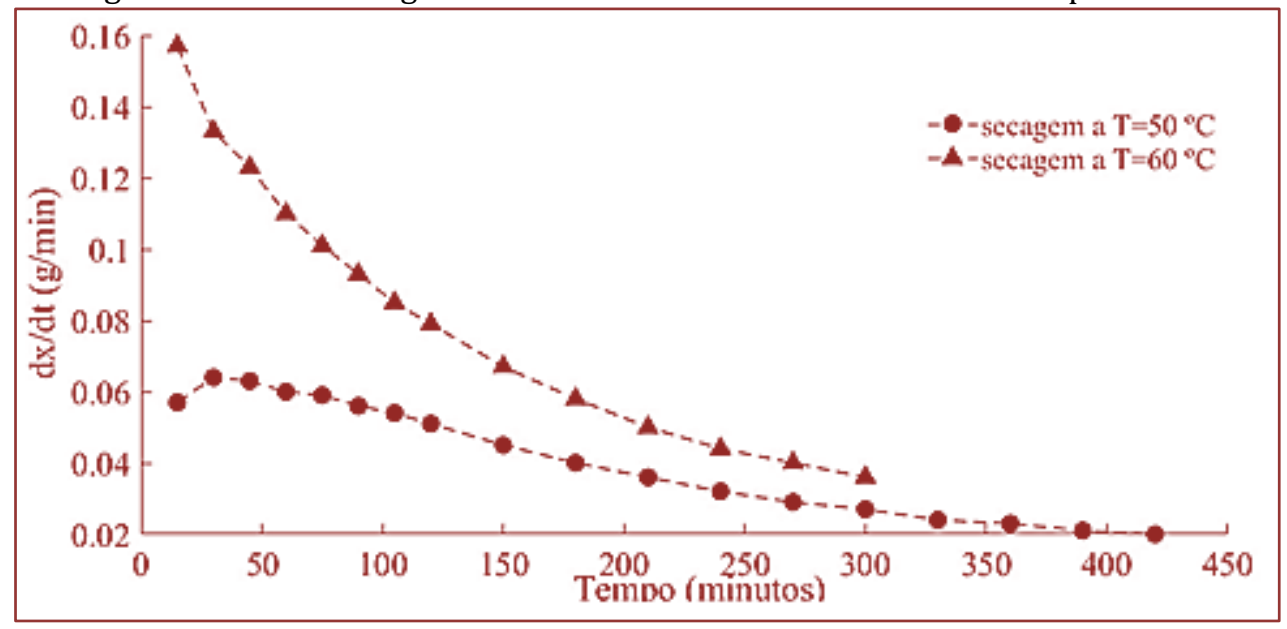

Ao observar a Figura 2, nota-se que a secagem da cúrcuma apresenta apenas um período de secagem, o período de taxa decrescente, isso é comum para alimentos, materiais com poros pequenos e demais materiais biológicos. Pode-se observar também que a taxa de secagem na temperatura de $60{ }^{\circ} \mathrm{C}$ é maior do que a $50{ }^{\circ} \mathrm{C}$, isso ocorre devido à maior transferência de calor e massa. Ao elevar a temperatura, aumentase a taxa com que a água é removida da superfície do alimento e a taxa de migração da água do interior para a superfície devido à maior ação da temperatura no mesmo (MARCINKOWSKI, 2006; PARK et al., 2014; TADINI et al., 2016). 0 mesmo comportamento foi relatado por Marcinkowski (2006) ao estudar a cinética de secagem da proteína texturizada de soja e por Dionello et al. (2009) ao estudar a secagem de fatias de abacaxi in natura. 


\section{CONCLUSÃO}

Por meio dos resultados obtidos pode-se concluir que as temperaturas influenciam na taxa de secagem da cúrcuma e consequentemente no tempo de secagem. E que os modelos de Midilli e de Page apresentaram melhor ajuste a secagem da cúrcuma.

\section{REFERÊNCIAS}

[1] ALMEIDA, L. P. Caracterização de pigmentos da Cúrcuma longa L., avaliação da atividade antimicrobiana, morfogenese in vitro na produção de curcuminóides e óleos essenciais. 2006. 120 f. Tese (Doutorado em Ciência de Alimentos) - Faculdade de Farmácia, Universidade Federal de Minas Gerais. Belo Horizonte, 2006.

[2] ANDRÉ, A. M.M. C. N.; CASTRO, D. S.; ALMEIDA, R. D.; MOREIRA, I. S. Análise e comparação dos modelos matemáticos da secagem do resíduo de manga 'Tommy Atkins'. Revista Verde de Agroecologia e Desenvolvimento Sustentável. v.9, p.01-06, 2014.

[3] BABALIS, S. J.; BELESSIOTIS, V. G. Influence of the drying conditions on the drying constants and moisture diffusivity during the thin-layer drying of figs. Journal of Food Engineering, v.65, n. 3, 449-458, 2004.

[4] BARBANTI, D.; MASTROCOLA, D.; PIZZARANI, S. Air drying of plums influence of some process parameters on the specific drying kinetics. Sciences des Aliments, Paris, v. 15, p. 19-29, 1995.

[5] CAMACHO, D. G.; BARROS, A. C. S. A.; PESKE, S. T.; MENEZES, N. L. A secagem de sementes. Ciência Rural, v.34, n.2, p.603-608, 2004.

[6] CECILIO FILHO, A. B. SOUZA, R. J.; BRAZ, L. T.; TAVARES, M. Cúrcuma: planta medicinal, condimentar e de outros usos potenciais. Ciência Rural, Santa Maria, v.30, n.1, 2000.

[7] DIONELlO, R. G.; BERBERT, P. A.; MOLINA, M. A. B.; PEREIRA, R. C.; VIANA, A. P.; CARLESSO, V. O. Secagem de fatias de abacaxi e Pré-desidratadas Por Imersão-impregnação: cinética e avaliação de modelos. Ciência e Tecnologia de Alimentos, v.29, n.1, p.232-240, 2009.

[8] FELLOWS, P. Tecnologia do processamento de alimentos: princípios e prática. 2. ed. Porto Alegre: Artmed, 2006.

[9] FOUST, A. S.; WENZEL, L. A.; CLUMP, C. W.; MAUS, L.; ANDERSEN, L. B. Princípios das Operações Unitárias. 2Ed. Rio de Janeiro: LTC, 2012.

[10] GONELLI, A. L. D. Variação das propriedades físico-mecânicas e da qualidade da mamona (Ricinus communis L.) durante a secagem e o armazenamento. 2008. 186 f. Tese (Doutorado em Engenharia Agrícola) - Universidade Federal de Viçosa, Minas Gerais, 2008.

[11] GONÇALVES, J. Q.; SILVA, M. A. P.; PLÁCIDO, G. R.; CALIARI, M.; SILVA, R. M.; MOURA, L. C.; SOUZA, D. G. Secagem da casca e polpa da banana verde (Musa acuminata): propriedades físicas e funcionais da farinha. Global Science and technology, Rio Verde, v.9, n.3, p.62-72, 2016.

[12] Instituto Adolfo Lutz. Métodos físico-químicos para análise de alimentos. 4⿳⺈ edição - 1o edição digital. São Paulo: Editora Instituto Adolfo Lutz, 2008. 1020 p.

[13] MAIA, S. R.; FERREIRA, A.C.; ABREU, L. R. Uso do açafrão (Curcuma longa L.) na redução da Escherichia coli (ATCC 25992) e Enterobacter aerogenes (ATCC 13048) em ricota. Ciência e Agrotecnologia, v.28, n.2, p.358-365, 2004.

[14] MARCINKOWSKI, E. A. Estudo da cinética de Secagem, Curvas de Sorção e Predição de Propriedades Termodinâmicas da Proteína Texturizada de Soja. 2006. 127f. Dissertação (Mestrado em Engenharia Química), Universidade Federal do Rio Grande do Sul, Porto Alegre, 2006.

[15] MIDILLI, A.; KUCUK, H.; YAPAR, Z. A new model for single-layer drying. Drying Technology, v.20, p.1503$1513,2002$.

[16] MOCHI, V. T. Efeito da Temperatura de Secagem no Rendimento do Óleo Essencial e Teor de 1,8-Cineol Presentes nas Folhas de Eucalyptus Camaldulensis. 2005. 75f. Dissertação (Mestrado em Engenharia Química), Universidade Estadual de Campinas, Campinas, 2005.

[17] PARK, K. J.; YADO, M. K. M.; BROD, F. P. R. Estudo de Secagem de Pêra Bartlett (Pyrus Sp.) em Fatias. Ciência e Tecnologia de Alimentos, v.21, n.3, p.288-292, 2001.

[18] PARK, K. J. B.; PARK, K. J.; ALONSO, L. F. T.; CORNEJO, F. E. P.; DAL FABBRO, I. M. Secagem: Fundamento e Equações. Revista Brasileira de Produtos Agroindustriais, v.16, n.1, p.93-127, 2014.

[19] PARVEEN, S.; KAILAPPAN, R.; DHANANCHEZHIYAN, P. Studies on Shrinkage of Turmeric Rhizomes During Drying. International Journal of Food and Nutritional Sciences, v.2, n.2, p.30-34, 2013. 
[20] POLÔNIO, M. L. T.; PERES, F. Consumo de aditivos alimentares e efeitos à saúde: desafios para a saúde pública brasileira. Caderno de Saúde Pública, v.25, p.1653-1666, 2009.

[21] PRASAD, J.; VIJAY, V.K.; TIWARI, G.N.; SORAYAN, V. P. S. Study On Performance Evaluation Of Hybrid Drier For Turmeric (Curcuma Longa L.) Drying At Village Scale. Journal of Food Engineering, v.75, p.497-502, 2006.

[22] PRATO, T. S. Influência da secagem sobre compostos medicinais e de pungência do gengibre. 2010. $84 \mathrm{f}$. Dissertação (Mestrado em Ciência e Tecnologia de Alimentos) - Universidade Estadual Paulista "Júlio de Mesquita Filho", São José do Rio Preto, 2010.

[23] SANTOS, D. C.; QUEIROZ, A. J. M.; FIGUEIRÊDO, R. M.F.; OLIVEIRA, E. N. A. Cinética de secagem de farinha de grãos residuais de urucum. Revista Brasileira de Engenharia Agrícola e Ambiental, v.17, n.2, p.223-231, 2013.

[24] SILVA, H. R. P.; CUCO, R. P.; PORCIUNCULA, B. D. A.; SILVA, C. Avaliação dos Parâmetros Termodinâmicos e Cinéticos de Cenouras Submetidas a Secagem Convectiva. E-xacta, v.10, n.2, p.73-80, 2017.

[25] SIMPSON, R.; RAMÍREZ, C.; NUÑEZ, H.; JAQUES, A.; ALMONACID, S. Understanding the success of Page's model and related empirical equations in fitting experimental data of diffusion phenomena in food matrices. Trends in Food Science e Technology, v. 62, 194-201, 2017.

[26] TADINI, C. C.; TELIS, V. R. N.; MEIRELLES, A. J. A.; PESSOA FILHO, P. A. Operações unitárias na indústria de alimentos. 1ํㅡ. Ed. Rio de Janeiro: LTC, 2016.

[27] VILELA, C. A. A.; ARTUR, P. O. Secagem do açafrão (Cúrcuma longa L.) em diferentes cortes geométricos. Ciência e tecnologia de alimentos, v.28, p.387-394, 2008.

[28] YALDIZ, O.; ERTEKI, C.; UZUN, H. I. Mathematical modeling of thin layer solar drying of sultana grapes. Energy, v.26, p.457-465, 2001. 


\section{Capítulo 14}

Moagem seca e condicionada do malte pilsen em moinho industrial de dois rolos em uma Instituição Privada do Centro-Oeste do Paraná

\section{Brayane Buhali}

Karina Czaikoski

Franciely Ignachewski

Resumo: Todas as etapas no processo de fabricação da cerveja são importantes para a obtenção de um produto final com qualidade. Particularmente, a moagem influencia na quantidade de cascas que auxiliarão no processo de clarificação e expõem o endosperma no processo de mosturação ao ataque das enzimas. A moagem do malte é realizada em sua maioria em moinho de rolos. Dessa forma, o presente estudo visou analisar os percentuais de frações obtidos em moagens com diferentes aberturas de rolos e realizadas moagens a seco e condicionadas. Para tal foram utilizadas as seguintes aberturas dos rolos: 0,$8 ; 1,0 ; 1,3 ; 1,6 ; 1,8$ e $2,0 \mathrm{~mm}$. Por meio deste trabalho foi possível verificar que a moagem seca com abertura de rolos de $1,0 \mathrm{~mm}$, resultou em valores para casca, griss grosso, griss fino I e II e farinha de griss de acordo com a literatura para moinho de dois rolos. Os valores para moagem seca e condicionada foram analisados estatisticamente, e todas as amostras variaram significativamente ao nível de 5\% para as frações analisadas.

Palavras-chave: cerveja, cascas, griss,endosperma, enzimas, frações. 


\section{INTRODUÇÃO}

Existem relatos de que a cerveja proveniente de cevada maltada já era produzida na Babilônia 6000 a.C. No território brasileiro, o hábito de consumir cerveja foi inserido por D. João VI, no começo do século XIX, no período de permanência da família real portuguesa no país. No ano de 1888 , na cidade do Rio de Janeiro a "Manufatura de Cerveja Brahma Villigier e Cia" promoveram a atividade cervejeira, sendo seguida pela "Companhia Antártica Paulista" na cidade de São Paulo em 1891 (DRAGONE; SILVA, 2010).

Acerca da produção, sabe-se que a nível global no ano de 2015 foram produzidos aproximadamente 189 milhões de litros de cerveja, sendo a China o maior produtor, a qual lidera esse posto pelo $14^{\circ}$ ano consecutivo, seguida dos Estados Unidos da América e do Brasil (KIRIN HOLDINGS, 2016). Grande parte da produção no Brasil provém das grandes cervejarias, como por exemplo: Grupo Ambev, Itaipava e Heineken. Entretanto, as microcervejarias vêm ganhando espaço no mercado brasileiro, devido à busca do consumidor por produtos cada vez mais diversificados, principalmente no quesito diversidade dos ingredientes e busca por novos aromas e sabores (REIS, 2016).

De acordo com o Decreto no 6.871, de 4 de junho de 2009, pode-se afirmar que a cerveja é a bebida obtida pela fermentação alcoólica do mosto cervejeiro oriundo do malte de cevada e água potável, por ação da levedura, com adição de lúpulo (BRASIL,2009). As etapas referentes ao processamento da cerveja são a moagem do malte, mosturação, clarificação do mosto, fervura, resfriamento, fermentação, maturação e envase (DRAGONE; SILVA, 2010).

A cevada é o cereal amplamente empregado no processo de malteação por apresentar teores adequados de amido e proteínas. As etapas do processo de malteação são: maceração, germinação e secagem. A qualidade do malte influencia diretamente nos processos de fabricação de cerveja e consequentemente na qualidade do produto final (SENAI, 2014; ESSLINGER, 2009; KUNZE, 2006).

Em relação ao processamento da cerveja, a moagem do malte é a primeira etapa e deve ser realizada da maneira adequada, pois moagens muito finas resultam em poucas cascas e moagens grossas, não expõem o endosperma ao ataque das enzimas. A moagem pode ser realizada em moinho de rolos ou de martelo, com os grãos secos, condicionados ou úmidos. Uma moagem realizada com abertura de rolos apropriados gera teores de casca ideais, as quais formam uma camada filtrante adequada e contribuem com o processo de clarificação do produto, etapa mais vigorosa da fabricação. A moagem apropriada também fornece teores de açúcares adequados, pois permite a exposição do endosperma ao ataque das enzimas que degradam o amido e geram os açúcares fermentescíveis. Consequentemente uma moagem realizada da maneira correta ocasiona um aumento de rendimento e economia para as cervejarias (BAMFORTH, 2006; DRAGONE; SILVA, 2010).

Portanto, o principal objetivo deste trabalho foi avaliar o processo de moagem do Malte Pilsen para elaboração de cerveja, utilizando diferentes aberturas do par de rolos do moinho.

\section{MATERIAL E MÉTODOS}

Para o desenvolvimento deste trabalho foram utilizados grãos de Malte Pilsen fornecidos por uma instituição privada. Foram utilizadas as instalações da empresa para as análises e coletas de dados.

\subsection{MOAGEM}

Para o processo de moagem foram realizados dois tratamentos diferentes para o malte: moagem seca e moagem condicionada. Utilizou-se para ambos os tratamentos $200 \mathrm{~g}$ do malte Pilsen, pesados em balança digital semi-analítica. Para a moagem condicionada borrifou-se sobre os grãos $10 \mathrm{~mL}$ de água a $30^{\circ} \mathrm{C}$, os quais permaneceram em repouso pelo período de 60 minutos. Posteriormente, os grãos foram moídos em moinho de dois rolos importado da marca Künzel conforme mostra a Figura 1 com a realização de 6 ensaios de moagem, variando a abertura dos rolos $(0,8 ; 1,0 ; 1,3 ; 1,6 ; 1,8$ e $2,0 \mathrm{~mm})$. 
Figura 1 - Moinho de dois rolos da marca Künzel.

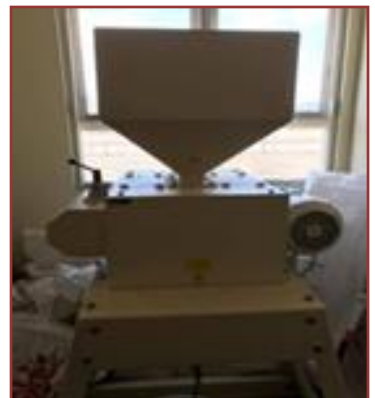

Fonte: a autora, 2017.

\subsection{ANÁLISES GRANULOMÉTRICAS}

Após o processo de moagem, as amostras de malte moído foram colocadas em equipamento composto por jogo de peneiras denominado "Plansichter"da marca Bühler-Miag. 0 equipamento possui 5 peneiras e o fundo. As peneiras devem possuir as seguintes granulometrias em ordem decrescente: 1,270 mm (cascas), $1,010 \mathrm{~mm}$ (griss grosso), 0,547 mm (griss fino I), 0,253 mm (griss fino II), 0,152 mm (farinha de griss). 0 conjunto de peneiras alcança 300 voltas/min por um intervalo de tempo de 5 minutos. Após o processo de agitação, as porções presentes nas peneiras foram pesadas em balança analítica e por fim, calculou-se a porcentagem em massa segundo uma Instrução de Trabalho estabelecida pela Instituição Privada (JACOB, 2002).

\subsection{ESTATÍSTICA}

Os resultados foram obtidos em duplicata e submetidos à Análise de Variância (ANOVA), sendo mencionados na forma de média e desvio padrão. Os resultados também foram avaliados mediante o teste de comparação de médias, pelo teste de Tukey, ao nível de significância de 5\%, utilizando o software STATISTICA 12.

\section{RESULTADOS E DISCUSSÃO}

Os percentuais obtidos das frações casca, griss grosso, griss fino I, griss fino II, farinha de griss e fundo por meio da análise granulométrica das diferentes moagens encontram-se nas Tabelas 1 e 2 .

Tabela 1 - Percentuais das diferentes frações de Malte Pilsen seco obtidas mediante moagem em moinho de dois rolos, valores médios e desvio de duplicatas

\begin{tabular}{|c|c|c|c|c|c|c|}
\hline \multirow{2}{*}{$\begin{array}{l}\text { Abertura dos } \\
\text { rolos de } \\
\text { moagem }(\mathrm{mm})\end{array}$} & \multicolumn{6}{|c|}{ Percentual de cada fração } \\
\hline & Casca & Griss Grosso & GrissFino I & Griss Fino II & Farinha de Griss & Fundo \\
\hline \multicolumn{7}{|l|}{ Moagem seca } \\
\hline 0,8 & $26,65^{f} \pm 0,18$ & $18,10^{a^{*} \pm 0,31}$ & $24,80^{\mathrm{a}^{*} \pm 0,02}$ & $11,09 \mathrm{a}^{*} \pm 0,0$ & $6,05^{a} \pm 0,08$ & $13,29 \underline{a} \pm 0,01$ \\
\hline 1,0 & $35,29 \mathrm{e} \pm 0,23$ & $19,00^{\mathrm{a}^{*} \pm 0,17}$ & $19,65^{b^{*}} \pm 0,09$ & $9,23^{b^{*}} \pm 0,00$ & $5,25^{b^{*} \pm 0,03}$ & $11,56^{\mathrm{b}} \pm 0,01$ \\
\hline 1,3 & $54,86^{d} \pm 0,32$ & $14,16^{b^{*} \pm 0,14}$ & $11,83^{c} \pm 0,08$ & $6,51^{c} \pm 0,06$ & $4,04 c^{*} \pm 0,04$ & $8,57 c \pm 0,26$ \\
\hline 1,6 & $69,17 \mathrm{c} \pm 0,34$ & $9,20^{c} \pm 0,11$ & $7,91^{\mathrm{d}} \pm 0,20$ & $4,41^{d} \pm 0,16$ & $3,09^{d} \pm 0,03$ & $6,42^{d} \pm 0,30$ \\
\hline 1,8 & $74,88^{\mathrm{b}} \pm 0,22$ & $7,13^{d} \pm 0,23$ & $6,35^{\mathrm{e}} \pm 0,12$ & $3,58^{e} \pm 0,23$ & $2,61^{\mathrm{e}} \pm 0,16$ & $5,42^{d} \pm 0,17$ \\
\hline 2,0 & $81,83^{a} \pm 0,10$ & $5,12^{\mathrm{e}} \pm 0,27$ & $4,37^{\mathrm{f}} \pm 0,25$ & $2,61^{f} \pm 0,05$ & $1,94^{\mathrm{f}} \pm 0,05$ & $4,10^{\mathrm{e}} \pm 0,08$ \\
\hline $\begin{array}{l}\text { (\%) padrão de } \\
\text { cada fração (1) }\end{array}$ & $28-35$ & $10-22$ & $18-32$ & $8-12$ & $4-6$ & $20-24$ \\
\hline
\end{tabular}

NOTA: *valores que estão dentro do intervalo de percentual de fração ideal; (1) NARZISS; BACK (2009); médias seguidas pela mesma letra na mesma coluna não diferem entre si pelo teste de Tukey a $5 \%$ de probabilidade. 
Tabela 2 - Percentuais das diferentes frações de Malte Pilsen condicionado obtidas mediante moagem em moinho de dois rolos, valores médios e desvio de duplicatas

\begin{tabular}{|c|c|c|c|c|c|c|}
\hline \multirow{2}{*}{$\begin{array}{l}\text { Abertura dos } \\
\text { rolos de } \\
\text { moagem (mm) }\end{array}$} & \multicolumn{6}{|c|}{ Percentual de cada fração } \\
\hline & Casca & Griss Grosso & GrissFino I & Griss Fino II & Farinha de Griss & Fundo \\
\hline \multicolumn{7}{|c|}{ Moagem condicionada } \\
\hline 0,8 & $47,68^{f} \pm 0,35$ & $7,02^{a} \pm 0,02$ & $12,99 a \pm 0,19$ & $8,78^{a^{*}} \pm 0,07$ & $5,44^{a^{*} \pm 0,13}$ & $18,07 a \pm 0,08$ \\
\hline 1,0 & $53,23^{e} \pm 0,28$ & $7,20^{a} \pm 0,29$ & $12,21^{\mathrm{b}} \pm 0,26$ & $7,53^{\mathrm{b}} \pm 0,02$ & $4,61^{b^{*} \pm 0,02}$ & $15,21^{b} \pm 0,23$ \\
\hline 1,3 & $61,96^{d} \pm 0,21$ & $7,29 a \pm 0,56$ & $9,42^{c} \pm 0,02$ & $5,92^{c} \pm 0,04$ & $3,67 \pm \pm 0,03$ & $11,70^{c} \pm 0,32$ \\
\hline 1,6 & $77,85^{c} \pm 0,44$ & $4,08^{b} \pm 0,10$ & $5,19 \mathrm{~d} \pm 0,26$ & $3,59^{d} \pm 0,02$ & $2,24 \mathrm{~d} \pm 0,11$ & $7,02^{d} \pm 0,19$ \\
\hline 1,8 & $82,96^{b} \pm 0,14$ & $3,04 \mathrm{c} \pm 0,17$ & $3,63 \mathrm{e} \pm 0,03$ & $2,75^{\mathrm{e}} \pm 0,00$ & $1,81^{\mathrm{d}} \pm 0,02$ & $5,78 \mathrm{e} \pm 0,02$ \\
\hline 2,0 & $90,22^{a} \pm 0,39$ & $1,59^{\mathrm{d}} \pm 0,04$ & $1,88^{f} \pm 0,02$ & $1,57 \mathrm{f} \pm 0,05$ & $1,22^{\mathrm{e}} \pm 0,01$ & $3,59 \mathrm{f} \pm 0,27$ \\
\hline $\begin{array}{l}\text { (\%) padrão de } \\
\text { cada fração (1) }\end{array}$ & $28-35$ & $10-22$ & $18-32$ & $8-12$ & $4-6$ & $20-24$ \\
\hline
\end{tabular}

NOTA: *valores que estão dentro do intervalo de percentual de fração ideal; (1) NARZISS; BACK (2009); médias seguidas pela mesma letra na mesma coluna não diferem entre si pelo teste de Tukey a $5 \%$ de probabilidade.

Como pode ser observado na Tabela 1, o processo de moagem realizado com abertura de 1,0 mm dos rolos possibilitou a obtenção de percentuais para casca, griss grosso, griss fino I e II e farinha de griss mais próximos com os valores publicados por Narziss e Back (2009) e empregado pela instituição privada como valores padrões. Contudo Narziss e Back realizaram este estudo com variedades de cevada cultivadas fora do território brasileiro, fator que influencia diretamente na qualidade de moagem. Tais percentuais são de grande importância, pois influenciam no rendimento do processo de fabricação da cerveja, o qual seria maior, devido à quantidade de cascas adequada para o processo de clarificação e exposição ideal do endosperma para o processo de degradação enzimática (NARZISS; BACK, 2009). Empregando a mesma abertura dos rolos e variando a condição de moagem dos grãos em secos e condicionados, observa-se que os percentuais obtidos para as frações com moagem seca apresentaram um maior número de valores dentro do considerado como padrão pela Instituição Privada. Por meio da análise estatística, verifica-se que para todas as aberturas empregadas, os valores das frações diferiram entre si pelo teste de Tukey a $5 \%$ de probabilidade.

De acordo com Kunze (2006) no processo de moagem seca, as cascas presentes são frágeis e facilmente quebradiças. Para proteger e conservar as cascas na moagem é realizado o processo de umedecimento dos grãos de malte, tornando as cascas mais friáveis, aumentando o seu volume em 10 a $20 \%$. Segundo Swajgier (2011) um percentual maior de cascas auxilia na formação da camada filtrante do processo de clarificação. No processo de fabricação da cerveja, a moagem condicionada proporciona um maior rendimento de extrato fermentescível, pois ocorre a migração de glicose, maltose, maltotriose e proteína do processo de mosturação ao mosto obtido por meio da etapa de clarificação.

Segundo Esslinger (2009), uma moagem adequada influencia diretamente para o processo de estabilidade do sabor da cerveja. As vantagens de um processamento adequado resultam em menor fragmentação da casca, melhor obtenção de griss, baixa extração de componentes da casca, obtenção de um produto final mais límpido, melhor filtração do mosto devido ao percentual adequado de cascas e ocasiona um maior rendimento do material.

\section{CONCLUSÃO}

O presente trabalho possibilitou estudar o processo de moagem do malte para elaboração de cerveja, utilizando diferentes aberturas do par de rolos do moinho e empregando duas condições distintas do malte, sendo estas, moagem com malte seco e condicionado.

A partir dos resultados obtidos concluiu-se que a moagem do Malte Pilsen seco foi mais adequada que a moagem dos grãos condicionados, pois os resultados obtidos para moagem condicionada em sua maioria ficaram fora dos limites definidos como padrão pela instituição privada. A moagem com os grãos secos utilizando a abertura dos rolos de 1,0 mm apresentou os valores mais próximos com os estabelecidos por Narziss e Back (2009).

É fundamental a aplicação dos testes de moagem em escala industrial para verificar o comportamento em relação ao processo de fabricação e assim determinar qual a moagem mais adequada para o moinho de 
dois rolos em relação aos grãos de cevada cultivados e malteados no território brasileiro. Os testes que verificam diretamente o processo de moagem com os grãos secos e condicionados são limitados.

\section{REFERÊNCIAS}

[1] BAMFORTH, C.W. Brewing: new technologie. Cambridge: Woodhead Publishing Limited, 2006.

[2] BRASIL. Decreto no 6871 de 4 de junho de 2009. Regulamenta a LEI n.8918 de 14 de julho de 1994, padronização, classificação, registro, inspeção e a fiscalização da produção e comércio de bebidas. Diário Oficial da República Federativa do Brasil, Brasília, D.F.,4 jun.2009.

[3] DRAGONE,G.;SILVA,J.B.A Cerveja. In: VENTURINI FILHO, W.G. Bebidas alcoólicas: ciência e tecnologia. São Paulo: Blucher, 2010.

[4] ESSLINGER, H.M. Hanbook of Brewing: Process, technology, markets. Freiburg: Wiley - VCH, 2009.

[5] JACOB, F. MEBAK - Mitteleuropäische Brautechnische Analysenkommission. 4 th ed. Freising: Weihenstephan, 2002.

[6] KIRIN HOLDINGS. Kirin Beer University Report Global Beer Production by Country in 2015. Disponível em: <http:// www.kirinholdings.co.jp/english/news/2016/0810_01.html>. Acesso em: 05/08/2017.

[7] KUNZE, W. Tecnología para Cerveceros y Malteros. Berlin: VLB Berlin, 2006.

[8] NARZISS, L; BACK,W. Die Bierbrauerei: die Technologie der Würzebereitung.8 ed. Weinheim: Wiley-VCH Verlag GmbH \& Co. KGaA, 2009.

[9] REIS, R.P da COSTA. Plano de negócios para microcervejaria artesanal. São Paulo : 2016. 110p. Trabalho de Formatura. Escola Politécnica da Universidade de São Paulo - USP.

[10] SENAI. Tecnologia Cervejeira.Vol.1 Rio de Janeiro: Sistema FIRJAN, 2014.

[11] SZWAJGIER, D. Dry and wet milling of malt. A preliminary study comparing fermentable sugar, total protein, total phenolics and the ferulic acid content in non-hopped worts. Journal of The Institute of Brewing, v. 117,n. 4 .p. 569-577,2011. 


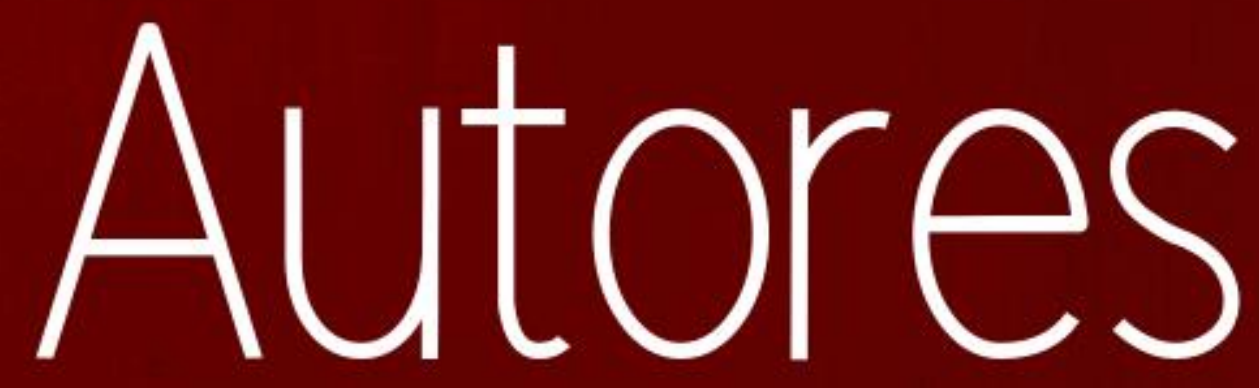




\section{ADRIANA BIASI VANIN}

Graduação, mestrado e doutorado em Engenharia de Alimentos pela Universidade Regional Integrada do Alto Uruguai e das Missões - Erechim. Experiência profissional na área de bebidas fermentadas e destiladas, na área de laticínios, e na área de administração empresarial. Na área acadêmica, conhecimento no equilíbrio de fases à baixas pressões, termodinâmica, biotecnologia, produção de aromas naturais via tecnologia enzimática, ferramentas da qualidade e obtenção de embalagens biodegradáveis. Consultora nível I pelo Programa Alimentos Seguros (PAS) e professora tempo integral e pesquisadora da UNOESC - Universidade do Oeste de Santa Catarina.

\section{ALINE CHICZTA}

Possui graduação em Engenharia de Alimentos pela Universidade Estadual do Centro-Oeste (2018). Pós graduada em Gestão da Qualidade e Segurança dos Alimentos pelo CESCAGE. Atualmente é autônoma.

\section{ÁLVARO VENTORINI VASCONCELOS}

Estudante do curso de Licenciatura em Química pela Universidade Estadual do Ceará - UECE e bolsista do LABBIOTEC ( Laboratório de bioquímica e tecnologia da uece) com bolsa ICT Funcap ,com pesquisa na área de alimentos.

\section{AMANDA BATISTA NASCIMENTO}

Graduada em Licenciatura em Química, pela Universidade Estadual do Ceará - UECE. Pósgraduanda em Bioquímica Aplicada a Tecnologia - UECE. Atua na área de Bioquímica e Química dos Alimentos, LABBIOTEC - UECE.

\section{ANA TERESA RODRIGUES FRANÇA}

Possui graduação em engenharia de alimentos pela Universidade Estadual de Maringá (UEM), dentre os projetos destaca-se a cinética de secagem de curcuma.

\section{ANDRÉA CÁTIA LEAL BADARÓ}

Graduada em Medicina Veterinária pela Universidade Federal de Minas Gerais (UFMG), Mestrado e Doutorado em Ciência e Tecnologia de Alimentos pela Universidade Federal de Viçosa (UFV). Docente no Departamento de Ciências Agrárias/Engenharia de Alimentos na Universidade Tecnológica Federal do Paraná (UTFPR) - Câmpus Francisco Beltrão. Pesquisadora da Rede de Pesquisas em Queijos Artesanais Brasileiros (REPEQUAB). Representante da Região Sul na Rede Brasileira de Pesquisadores em Soberania e Segurança Alimentar e Nutricional. Atua na área de Ciência e Tecnologia de Alimentos, com ênfase em Leite e derivados, Avaliação e Controle de Qualidade de Alimentos, Microbiologia de Alimentos, Boas Práticas de Manipulação, Segurança Alimentar e Nutricional, Treinamentos de Manipuladores, Vigilância Sanitária, Qualidade dos Alimentos e Alimentos Seguros.

\section{ANDRESSA RAFAELLA DA SILVA BRUNI}

Graduada em Engenharia de Alimentos pela Universidade Estadual do Centro-Oeste (2018), onde realizou projetos de iniciação científico relacionados ao desenvolvimento de novos produtos. Atualmente cursa Mestrado em Tecnologia de Alimentos pela Universidade Tecnológica Federal do Paraná e especialização em Engenharia de Segurança do Trabalho pela Faculdade Educamais.

\section{ANGELA MARIA PICOLLOTO}

Bacharel, Mestre e Doutora em Física da Matéria Condensada, com ênfase em análises termofísicas pela Universidade Estadual de Maringá (UEM). Atualmente realiza pesquisas científicas estudando 
e caracterizando as propriedades físico-químicas de óleos essenciais e filmes biodegradáveis. Integrante do Grupo de Pesquisa em Filmes Biodegradáveis e Ativos (GPFBA). Autora e co-autora de 36 trabalhos publicados em congressos, 2 artigos completos e 3 capítulos de livro.

\section{ANGELITA DA SILVEIRA MOREIRA}

Possui graduação em Farmácia e Bioquímica pela Universidade Católica de Pelotas (1992), mestrado em Ciências Farmacêuticas pela Universidade Federal do Rio Grande do Sul (1996) e doutorado em Biotecnologia (nível 7) pela Universidade Federal de Pelotas (2002). Tem experiência nas áreas de farmácia, microbiologia, ciência e tecnologia de alimentos e química, com ênfase em Microbiologia Industrial e de Fermentação, fitoquímica e farmacotécnica e tecnologia de alimentos, atuando principalmente nos seguintes temas: produção, caracterização, modificação química e aplicação de biopolímeros extra e intracelulares em diferentes áreas, como atestam os diversos pedidos de patentes.

\section{BARBARA DANIELE ALMEIDA PORCIUNCULA}

Possui graduação em Engenharia de Alimentos pela Fundação Universidade Federal de Rio Grande (FURG). Mestrado e doutorado em Engenharia de Alimentos pela Universidade Federal de Santa Catarina (UFSC). Possui experiência em Ciência e Engenharia de Alimentos. Atualmente é professora adjunta na Universidade Estadual de Maringá (UEM). Dentre os projetos destacam-se o estudo da decomposição de pescado, modificação enzimática de proteínas, síntese de ésteres e diferentes tipos de secagem e desidratação de frutas.

\section{BRAYANE BUHALI}

Possui graduação em Engenharia de Alimentos pela Universidade Estadual do Centro-Oeste UNICENTRO (2017), técnica em Química pelo Colégio Imperatriz Dona Leopoldina (2013), técnica cervejeira pela Escola Superior de Cerveja e Malte, pós graduada em Gestão da Qualidade pela UNOPAR. Atualmente é analista da qualidade na empresa IREKS DO BRASIL S.A. Possui experiência na área de análises, microbiologia, bebidas e panificação.

\section{BRUNA ALBIERO}

Graduanda do curso de Engenharia Química pela Universidade do Oeste de Santa Catarina Unoesc, campus Joaçaba. Atualmente sou bolsista do Conselho Nacional de Desenvolvimento Científico e Tecnológico (CNPq), atuando como pesquisadora na área das propriedades químicas e biológicas em produtos naturais.

\section{BRUNO PODOLAK}

Graduado em Engenharia de Alimentos pela UNICENTRO. Atua como encarregado de obras de Saneamento na Empresa Podolak Servicos de Saneamento Ltda.

\section{CAROLINE PEREIRA DAS NEVES}

Possui graduação em Nutrição pela Universidade Federal de Pelotas (2016). Mestra em Nutrição e Alimentos pelo programa da Universidade Federal de Pelotas.Tem experiência na área de Nutrição, com ênfase na área de Microbiologia, Qualidade e Segurança de Alimentos. Atualmente é doutoranda do Programa de Pós-Graduação em Nutrição e Alimentos da Universidade Federal de Pelotas.

\section{CLAIRE TONDO VENDRUSCOLO}

Possui graduação em Química Industrial pela Universidade Federal de Santa Maria (1976), mestrado em Ciência e Tecnologia Agroindustrial pela Universidade Federal de Pelotas (1988) e doutorado em Engenharia de Alimentos pela Universidade Estadual de Campinas (1995). 
Professora Titular na Universidade Federal de Pelotas. Tem experiência na área de Ciência e Tecnologia de Alimentos: trabalhou 07 anos como Gerente de Controle de Qualidade na Indústria Agapê S.A Ind. da Alimentação e 13 anos como Profa. do Curso Técnico em Alimentos/UFPel. E como Profa. Universitária a partir de 1997 até Julho de 2015. A ênfase em pesquisa é na área de produção de biopolímeros bacterianos .

\section{DAIANE CRISTINA LENHARD}

Graduada em Engenharia Química pela Universidade Estadual do Oeste do Paraná (2004), possui mestrado em Engenharia Química pela Universidade Estadual de Maringá (2006) e doutorado em Engenharia Química pela Universidade Estadual de Maringá (2010). Atualmente é professor adjunto da Universidade Tecnológica Federal do Paraná, Campus Medianeira. Tem experiência nas áreas de Engenharia Química e Engenharia de Alimentos, com ênfase no estudo e tratamento de efluentes industriais, cinética de secagem de frutas, reologia de fluidos alimentícios, estudo e aplicação de fungos lingninolíticos na degradação de compostos e na produção de exopolissacarídeos.

\section{DANIELA PAULA SCANAGATTA}

Graduada em Tecnologia em Controle de Processos Químicos pela UTFPR-PB. Especialista em Engenharia de Produção pela Fatec Internacional. Graduada em Tecnologia em Alimentos pela UTFPR-FB. Especialista em Gestão da Segurança de Alimentos pelo Senac. Especialista em Qualidade Sanitária de Alimentos pela Faculdade IPPEO. Atua há mais de 10 anos em Indústria de Laticínios, na qual é a Responsável Técnica e responde pela área de Gestão da Qualidade.

\section{DANYELLY SILVA AMORIM}

Mestranda em Ciência de Alimentos pela Universidade Estadual de Campinas (UNICAMP). Graduação em tecnologia de alimentos pela Universidade do Estado do Pará (UEPA). Tem experiência na área de Ciência e Tecnologia de Alimentos, com ênfase em Tecnologia de Alimentos, atuando principalmente nos seguintes temas: aproveitamento de resíduos de frutas na elaboração de alimentos, qualidade nutricional e compostos bioativos de alimentos.

\section{DEBORAH SANTESSO BONNAS}

Possui graduação em Agronomia pela Universidade Federal de Lavras (1987), mestrado em Ciências dos Alimentos pela Universidade Federal de Lavras (1991) e doutorado em Ciências dos Alimentos pela Universidade Federal de Lavras (2002). Iniciou as atividades profissionais como Instrutora Técnica no Centro Tecnológico de Alimentos do SENAI em Uberlândia em 1992. Em 1995, foi promovida ao cargo de Supervisora Técnica de Centro Tecnológico, conciliando as atividades de ensino com a coordenação das ações de pesquisa aplicada e assistência técnica e tecnológica. Em 1998, ingressou na Rede Federal, na Escola Agrotécnica Federal de Rio Verde e, em 1999, na Escola Agrotécnica Federal de Uberlândia. Participou efetivamente da elaboração de vários Projetos Pedagógicos de Cursos, inclusive do primeiro Curso de Graduação da Instituição ? Tecnologia em Alimentos? o qual coordenou de 2004 a 2008. Em 2007, foi indicada para compor a equipe editorial da Revista Brasileira de Educação Profissional e Tecnológica, enquanto ainda era editada pela SETEC. Atualmente, é editora da Revista Inova na área de Ciência e Tecnologia de Alimentos. Em 2006, foi selecionada para atuar como avaliadora de Cursos de Graduação e do Banco Nacional de Itens/BNI-ENADE. Em setembro de 2010, foi indicada para o cargo de PróReitora de Desenvolvimento Institucional, o qual exerceu até setembro de 2012. Exerceu o Cargo de Diretora de Ensino, Pesquisa e Extensão do Campus Uberlândia do IFTM de 2012 até outubro de 2016. Como professora, atua nos Cursos Técnicos, de Graduação e Pós-Graduação lato sensu no Campus Uberlândia, além de ser professora do Curso de Mestrado Profissional em Ciência e Tecnologia de Alimentos no Campus Uberaba. Orientou 36 Trabalhos de Conclusão de Cursos de Graduação e 13 de Especialização. Na área da pesquisa, destacam-se 15 trabalhos de iniciação científica concluídos e um em andamento; 26 artigos científicos publicados em periódicos e dois capítulos de livros. No Mestrado, tem nove orientações concluídas e quatro em andamento. Na extensão, desenvolveu diversos projetos com repercussão na comunidade, incluindo projetos 
internacionais, resultando em 24 orientações e cinco publicações de relatos de experiência. Atualmente é professor do ensino básico tecnico e tecnológico do Instituto Federal do Triângulo Mineiro. Tem experiência na área de Ciência e Tecnologia de Alimentos, com ênfase em Ciência e Tecnologia de Alimentos, atuando principalmente nos seguintes temas: boas práticas de fabricação, segurança alimentar, higiene, microbiologia de alimentos e análise sensorial.

\section{EDUARDA CAETANO PEIXOTO}

Possui graduação em Alimentos pela Universidade Federal de Pelotas formada em 2017. Especialista em ciência e tecnologia de alimentos, na área de concentração de frutas e hortaliças pela UFPel. Trajetória acadêmica com participações em congressos Nacionais e Internacionais, bem como apresentação de trabalhos, publicações em livros, organização de eventos, participação de projetos de Pesquisa, Ensino e Extensão. Experiência acadêmica na área de Ciência e Tecnologia de Alimentos, com ênfase em disciplinas de análise de alimentos, como: análise de matérias primas de origem animal e vegetal, análise físico-química de alimentos. Experiência em indústria de laticínios, relacionadas em análises de plataforma no recebimento do leite cru refrigerado; laboratório de físico-química e microbiologia e controle de qualidade do produto acabado. Atualmente é mestranda do Programa de Pós-Graduação em Nutrição e Alimentos da Universidade Federal de Pelotas.

\section{ELAINE ALVES DOS SANTOS}

Possui graduação em Tecnologia em Alimentos pelo Instituto Federal de Educação Ciência e Tecnologia do Triângulo Mineiro - Campus Uberlândia. Doutoranda em Ciência e Tecnologia de Alimentos pela Universidade Federal de Goiás (UFG). Mestre em Ciência e Tecnologia de Alimentos pelo IFTM - Campus Uberaba. Especialista em Tecnologia e Qualidade de Alimentos Vegetais pela Universidade Federal de Lavras (UFLA). Foi Professora Substituta do IFTM - Campus Uberlândia, ministrou aulas nas disciplinas de Industrialização de Carnes e Derivados, Microbiologia de Alimentos, Sistemas de Segurança Alimentar e Higiene Industrial (Abril de 2013 a Março de 2015). É técnica de Laboratório da Área de Alimentos, responsável pelos laboratórios de processamento de carnes e laticínios do IFTM - Campus Uberlândia. É coordenadora do curso Técnico em alimentos e nutrição do Colégio Profissional, ministrando aulas nas disciplinas de Tecnologia de leite e derivados e Tecnologia de Carnes e derivados.

\section{ELIEZER AVILA GANDRA.}

Graduado em Engenharia de Alimentos pela Fundação Universidade Federal do Rio Grande - FURG (2001), Mestrado (2003) e Doutorado (2006) em Ciência e Tecnologia Agroindustrial pela Universidade Federal de Pelotas - UFPEL. Atualmente é Professor Associado do Centro de Ciências Químicas, Farmacêuticas e de Alimentos - CCQFA e docente permanente dos Cursos de PósGraduação em Ciência dos Alimentos (Especialização), Mestrado Profissional em Ciência e Tecnologia de Alimentos - CMPCTA e do Programa de Pós Graduação em Nutrição e Alimentos PPGNA, todos da UFPEL. Foi coordenador do curso de Bacharelado em Química de Alimentos (UFPEL), do curso de Tecnologia em Alimentos (UEM) e do curso de Pós-Graduação em Ciência dos Alimentos da UFPEL. Tem experiência na área de Ciência e Tecnologia de Alimentos, com ênfase em Microbiologia de Alimentos, Compostos Bioativos, Biotecnologia e Ciência e Tecnologia de Produtos de Origem Animal, atuando em pesquisa principalmente nos seguintes temas: Antimicrobianos, Coberturas Bioativas, Microrganismos Patogênicos, Métodos Moleculares e Ciência e Tecnologia de Carnes e Leites. É avaliador do Sistema ARCU-SUL da Rede de Agências Nacionais de Acreditação (RANA) do Mercosul e também de cursos de graduação pertencente ao Banco de Avaliadores do Sistema Nacional de Avaliação da Educação Superior - BASis.

\section{ERICA CARNEIRO DE SOUSA}

Graduada no curso de Licenciatura em Química pela Universidade Estadual do Ceará - UECE. 


\section{FABIANE PICININ DE CASTRO CISLAGHI}

Graduada em Farmácia e Bioquímica Tecnologia dos Alimentos pela Universidade Federal de Santa Maria (UFSM), com Mestrado e Doutorado em Ciência dos Alimentos pela Universidade Federal de Santa Catarina (UFSC). É professora do Departamento de Ciências Agrárias/Engenharia de Alimentos na Universidade Tecnológica Federal do Paraná (UTFPR) - Câmpus Francisco Beltrão. Pesquisadora da Rede de Pesquisas em Queijos Artesanais Brasileiros (REPEQUAB). Tem experiência na área de Ciência e Tecnologia de Alimentos, atuando principalmente nos seguintes temas: Leite e derivados (com ênfase em Queijos, Lácteos fermentados e Bebidas Lácteas), Queijos artesanais, Aproveitamento do soro de leite, Segurança Alimentar e Nutricional e Lácteos Funcionais - Probióticos e Prebióticos.

\section{FELIPE BALICKI CORRÊA}

Possui graduação em Engenharia de Alimentos pela Universidade Estadual do Centro-Oeste (2018). Atualmente atua na Indústria de Alimentos na área de Produtos de Origem Animal.

\section{FRANCIÉLY IGNACHEWSKI}

Possui pós-graduação em nível de doutorado em Química Inorgânica pela associação UEL-UEPGUNICENTRO. Possui pós-graduação em nível de mestrado e graduação em química (Bacharelado e Licenciatura), ambos pela Universidade Estadual do Centro-Oeste (2006). Tem experiência na área de Química, com ênfase em Química Inorgânica, Química de Materiais e Química Ambiental. Atuando principalmente nos seguintes temas: Método Sol-Gel, Óxidos de Ferro, Óxido de Titânio, Zeólitas, Síntese e Caracterização de Materiais, Catalisador Imobilizado, Fotocatalisador, Tratamento de Resíduo, Processos Oxidativos Avançados.

\section{GABRIELLY RIBEIRO CARNEIRO}

Cursa Engenharia de Alimentos na Universidade Federal do Paraná Campus Avançado Jandaia do Sul. Atualmente é integrante do Grupo de Pesquisa em Tecnologias e Produção Agrícola na linha de pesquisa intitulada "Aproveitamento de resíduos agroindustriais" e participa do projeto "Caracterização, desenvolvimento e avaliação de produtos na área de alimentos".

\section{GEOVANA COSTA AGUIAR}

Estudante do curso de Licenciatura em Química pela Universidade Estadual do Ceará - UECE e bolsista do LABBIOTEC ( Laboratório de bioquímica e tecnologia da uece) como pesquisadora na área de alimentos e monitora da cadeira de Química dos Alimentos.

\section{GLÁUCIA FREIBERGER}

Graduanda de Engenharia Química pela Universidade do Oeste de Santa Catarina (UNOESC). Atualmente sou bolsista do Programa de Bolsas do Fundo de Apoio à Manutenção e ao Desenvolvimento da Educação Superior (FUMDES) em parceria com empresa e voluntária em projetos de pesquisa científica e de inovação na área de produtos naturais e suas propriedades químicas e biológicas.

\section{HERTA STUTZ}

Bióloga, com carreira científica consolidada, possui paixão pelo ensino. Atua como professora (associada A) na Universidade Estadual do Centro-Oeste (PR) onde leciona, entre outras, a disciplina de Desenvolvimento de Novos Produtos, que gerou o trabalho apresentado nesta publicação. 


\section{INGRYD RODRIGUES MARTINS}

Possui graduação em Tecnologia de Alimentos pela Universidade do Estado do Pará (2018). Mestrado em Desenvolvimento Rural e Gestão de Empreendimentos Agroalimentares (Em andamento). Tem experiência na área de Ciência e Tecnologia de Alimentos, com ênfase em Higiene e Controle de Qualidade / Pesquisa e Desenvolvimento de novos produtos / Microbiologia.

\section{ISABELLY SILVA AMORIM}

Mestranda em Ciência e Tecnologia de Alimentos pela Universidade Federal do Pará. Tem experiência na área de Ciência e Tecnologia de Alimentos, com ênfase em Tecnologia de Alimentos, atuando principalmente nos seguintes temas: utilização de resíduo de frutas em alimentos, qualidade nutricional e bioativa de alimentos.

\section{JAMILLE DE SOUSA MONTEIRO}

Graduanda em Tecnologia de Alimentos pela Universidade do Estado do Pará. Tem experiência na área de Ciência e Tecnologia de Alimentos, com ênfase em Tecnologia de Produtos de Origem Animal. E experiência na área de Ciência e Tecnologia de Alimentos, com ênfase em Tecnologia de Alimentos

\section{JAQUELINE DOS SANTOS DE OLIVEIRA}

Graduanda do 3o ano de Engenharia de Alimentos pela Universidade Estadual de Maringá - UEM. Atualmente é bolsista de iniciação científica pelo segundo ano consecutivo, com 4 trabalhos publicados em congressos. Integrante do Grupo de Pesquisa em Filmes Biodegradáveis e Ativos (GPFBA) atuando na pesquisa de filmes biodegradáveis.

\section{JOÃO PAULO DE PAIVA LEMOS}

Discente de Tecnologia em Alimentos na Universidade Federal de Pelotas, iniciação cientifica no Laboratório de Ciência dos Alimentos e Biologia Molecular, atuando atualmente no Laboratório de Óleos e Gorduras da Universidade Federal de Pelotas.

\section{JOSÉ CARLOS AZZOLINI}

Possui graduação em Química pela Universidade Federal de Santa Maria (1987) e mestrado em Engenharia de Produção pela Universidade Federal de Santa Catarina (2002). Atualmente é professor titular da Universidade do Oeste de Santa Catarina. Tem experiência na área de Química, com ênfase em Análise de Traços e Química Ambiental, atuando principalmente nos seguintes temas: águas industriais, parâmetros e tratamentos, poluição de águas superficiais e subterrâneas, lodo ativado, lançamento de efluente e dimensionamento de sistemas.

\section{KAMILA DE LIMA BARBOSA}

Graduada no curso de Licenciatura em Química pela Universidade Estadual do Ceará - UECE e integrante do grupo de pesquisa do LABIOTEC( Laboratório de bioquímica e tecnologia da uece) na área de produtos naturais.

\section{KANANDA LARA SANTOS SALES}

Graduada no curso de Licenciatura em Química pela Universidade Estadual do Ceará - UECE, Pós graduanda em Educação Especial e Inclusiva e integrante do grupo de pesquisa do LABIOTEC (Laboratório de bioquímica e tecnologia da uece) na área de produtos naturais. 


\section{KARINA CZAIKOSKI}

Possui graduação em Engenharia de Alimentos pela Universidade Estadual do Centro-Oeste UNICENTRO (2008), mestrado em Ciência de Alimentos pela Universidade Estadual de Londrina (2011) e doutorado em Engenharia de Alimentos pela Universidade Federal do Paraná - UFPR (2014). Atualmente é Professora Adjunto B da Universidade Estadual do Centro-Oeste. Tem experiência na área de Ciência e Tecnologia de alimentos com ênfase em Bioquímica, Microbiologia, Análise de alimentos e Extração de produtos naturais.

\section{KARINE GABRIEL}

Graduada em Tecnologia em Alimentos, atuou por cinco anos na área de laticínios. Atualmente não atua no ramo alimentício.

\section{KÁSSIA RODRIGUES DA COSTA SENA}

Engenheira de Alimentos pela Universidade Federal do Maranhão - UFMA. Especialista em Engenharia de Segurança do Trabalho - Galileo Business School. Pós graduanda Lato Sensu em Segurança Alimentar e Controle de Qualidade na Indústria de Alimentos - UEPA e Mestranda do Curso de Desenvolvimento Rural e Gestão de Empreendimentos Agroalimentares - IFPA.

\section{KEILA DE SOUZA SILVA}

Graduada em Engenharia de Alimentos, com Mestrado, Doutorado e Pós Doutorado em Engenharia e Ciência de Alimentos pela Universidade Estadual Paulista - UNESP. Atuou como investigador externo na Faculdade de Engenharia Química da Universidade do Porto (Portugal). Atualmente é docente adjunto e líder do Grupo de Pesquisa em Filmes Biodegradáveis e Ativos (GPFBA) da Universidade Estadual de Maringá (UEM). Já ministrou disciplina e apresentou palestras em congressos com o tema embalagens biodegradáveis. É autora e co-autora de 16 artigos publicados, 2 capítulos de livros, 85 trabalhos apresentados em congressos e 4 trabalhos premiados. Orientou e orienta alguns trabalhos de iniciação científica, conclusão de curso de graduação, mestrado, doutorado e pós doutorado.

\section{KENNIDY DE BORTOLI}

Possui graduação em Engenharia de Alimentos pela Universidade Tecnológica Federal do Paraná, campus Medianeira (2015). Tem experiência na área de Ciência e Tecnologia de Alimentos, com ênfase em Engenharia de Alimentos, secagem por método de spray drying, microencapsulação, desenvolvimento de novos produtos. Atualmente trabalha como pesquisador na área de queijos finos no Parque Científico e Tecnológico de Biociências (Biopark)

\section{KESSIA OLIVEIRA TARGINO}

Graduada no curso de Licenciatura em Química pela Universidade Estadual do Ceará - UECE.

\section{LAÍS RAVAZZI AMADO}

Graduada em Engenharia de Alimentos pela Universidade Estadual Paulista "Júlio de Mesquita Filho" - IBILCE/UNESP (2014). Mestre em Engenharia e Ciência de Alimentos pela UNESP (2017). Cursando Doutorado em Engenharia e Ciência de Alimentos também pela UNESP. Integrante do Grupo de Pesquisa em Filmes Biodegradáveis e Ativos (GPFBA). Autora de 4 artigos completos publicados em periódicos, 2 capítulos de livros e 13 trabalhos completos publicados em anais de congressos. 


\section{LEIDI DAIANA PREICHARDT}

Possui graduação em Química Industrial de Alimentos pela Universidade Regional do Noroeste do Estado do Rio Grande do Sul (2006) e mestrado e doutorado em Ciência e Tecnologia de Alimentos pela Universidade Federal de Pelotas (2009 e 2013). Atualmente é professora do Instituto Federal Farroupilha. Tem experiência na área de Ciência e Tecnologia de Alimentos e em microbiologia industrial.

\section{LEOMARA FLORIANO RIBEIRO}

Possui graduação em Engenharia de Alimentos pela Universidade Estadual do Centro-Oeste (2006). Especialista em Gestão da Qualidade na Produção de Alimentos, Medicamentos e Cosméticos pela Pontifícia Universidade Católica do Paraná (2009). Mestrado em Engenharia de Alimentos pela Universidade Federal do Paraná (2012). Doutorado em Engenharia de Alimentos pela Universidade Federal do Paraná (2016). Atua como professora Adjunta II da Universidade Federal do Paraná, Campus Avançado Jandaia do Sul. As pesquisas atuais estão voltadas para a extração, quantificação e avaliação do potencial antioxidante de compostos bioativos presentes em matérias-primas e produtos vegetais como também provenientes do aproveitamento de resíduos agroindustriais.

\section{MÁRCIA AROCHA GULARTE}

Possui graduação em Ciências Domésticas e Licenciatura em Economia Familiar pela UFPel (1992), especialização em Ciência dos Alimentos pela UFPel (1995), mestrado em Ciências dos Alimentos pela Universidade Federal de Santa Catarina (1998), doutorado em Ciência e Tecnologia Agroindustrial (com estágio sanduíche na Universidad de Valladolid, Espanha) pela UFPel (2005) e pós-doutorado em Agroquímica e Tecnologia de Alimentos pelo IATA - Valencia, Espanha (2011). Professora associada da Universidade Federal de Pelotas (UFPel), RS, Brasil. Tem experiência na área de Ciência e Tecnologia de Alimentos, com ênfase em Análise Sensorial e produtos de panificação para necessidades especiais, atuando também em características de cocção e sensorial de arroz e controle de qualidade.

\section{MARCOS DANIEL DAS NEVES SOUSA}

Graduado em Tecnologia de Alimentos pela Universidade do Estado do Pará (2018). Tem experiência na área de Ciência e Tecnologia de Alimentos, com ênfase em Tecnologia de Produtos de Origem Vegetal. Atualmente cursando Pós-Graduação Lato sensu em Segurança Alimentar e Controle de Qualidade na Indústria de Alimentos.

\section{MARIA DA CONCEIÇÃO TAVARES CAVALCANTI LIBERATO}

Possui graduação em Química Industrial pela Universidade Federal do Ceará (1973), especialização em Química Orgânica pela Universidade Federal do Rio de Janeiro (1979), mestrado em Tecnologia de Alimentos pela Universidade Federal do Ceará (2002). É Doutora em Biotecnologia em Recursos Naturais pela Rede Nordeste de Biotecnologia (RENORBIO). É Professora Associado com dedicação exclusiva da Universidade Estadual do Ceará e Professora Colaboradora do Mestrado Acadêmico em Recursos Naturais (MARENA), do Centro de Ciências e Tecnologia da Universidade Estadual do Ceará e autora de livros de ensino.

\section{MARIA RENARA ALVES RODRIGUES}

Tecnóloga de Alimentos e Pós-Graduanda em Segurança Alimentar e Controle da Qualidade na Indústria de Alimentos pela Universidade do Estado do Pará (UEPA). Exerceu atividades de monitoria no Laboratório de Microbiologia da UEPA, atualmente é Analista de Laboratório na área de Controle de Qualidade na empresa Xingu Fruit Polpas de Frutas Indústria e Comércio LTDA. Possui conhecimentos na área de Tecnologia de Alimentos. 


\section{NATHÁLIA MAIOLI CREMA}

Cursa Engenharia de Alimentos na Universidade Federal do Paraná Campus Avançado Jandaia do Sul. Atualmente é integrante do Grupo de Pesquisa em Tecnologias e Produção Agrícola na linha de pesquisa intitulada "Aproveitamento de resíduos agroindustriais" e participa do projeto "Caracterização, desenvolvimento e avaliação de produtos na área de alimentos".

\section{RENATA ALMEIDA FARIAS}

Licenciada em Química pela Universidade Estadual do Ceará - UECE, e integrante do grupo de pesquisa do LABIOTEC (Laboratório de bioquímica e tecnologia da uece) na área de produtos naturais

\section{TATIANE KUKA VALENTE GANDRA}

Possui curso Técnico em Alimentos pelo Centro Federal de Educação Tecnológica do Paraná (1996), graduação em Engenharia de Alimentos pela Universidade Estadual do Centro-Oeste (2003), Especialização em Ciência dos Alimentos pela Universidade Federal de Pelotas (2010), Mestrado em Ciência e Tecnologia Agroindustrial - Área de Microbiologia Agroindustrial pela Universidade Federal de Pelotas (2011), Doutorado em Ciência e Tecnologia de Alimentos - Área de Microbiologia Agroindustrial pela Universidade Federal de Pelotas (2015), graduação em Tecnologia em Gastronomia pela Universidade Federal de Pelotas (2019), Especialização em Gastronomia Contemporânea pela Faculdade UNYLEYA (2019). Trabalhou em empresas do ramo alimentício em áreas como: abate de aves, desenvolvimento de novos produtos, controle de qualidade de malte, de produtos pré-cozidos e confeitaria. Também, atuou como Professora da Universidade Estadual de Maringá nos cursos de Tecnologia em Alimentos e Tecnologia em Meio Ambiente e da Universidade Federal de Pelotas nos cursos de Tecnologia em Alimentos e Química de Alimentos. Foi consultora de cursos de Boas Práticas para Serviços de Alimentação pelo SENACRS e professora particular de disciplinas do ensino fundamental e do ensino médio. Trabalhou com pesquisas na área de Microbiologia de Alimentos envolvendo Análise de Risco Microbiológico em processo de abate de bovinos, análises microbiológicas de bactérias patogênicas em alimentos, avaliação da produção de biofilme e quantificação de níveis de expressão gênica por RT-qPCR, em biofilme produzido por Listeria monocytogenes. Atua principalmente nas áreas de Gastronomia, Controle de Qualidade de Alimentos, Segurança Alimentar, Análise Sensorial, Desenvolvimento de Novos Produtos, Tecnologia de Produtos de Origem Animal, Embalagens para Alimentos, Microbiologia e Higiene de Alimentos, Processos de Conservação de Alimentos, Biologia Molecular aplicada a Microbiologia de Alimentos e Gastronomia molecular. Atualmente é Professora Adjunta da Universidade Federal de Pelotas - Faculdade de Nutrição - Curso Superior de Tecnologia em Gastronomia.

\section{VALÉRIA OLIARI MORETO}

Possui graduação em Engenharia de Alimentos pela Universidade Estadual do Centro-Oeste (2018), onde desenvolveu projetos de Iniciação Científica voltados à Ciência e Tecnologia de Alimentos com ênfase no desenvolvimento de novos produtos. Atualmente atua na Indústria de Alimentos com experiência em Produtos de Origem Animal

\section{VANESSA GARCIA MONTEIRO}

Formada em Gastronomia pela Universidade Federal de Pelotas no ano de 2019/2. Atualmente faz especialização em Ciência dos Alimentos na mesma instituição. Possui grande experiência na organização e realização de eventos, área em que sua empresa atua a mais de 10 anos. 
